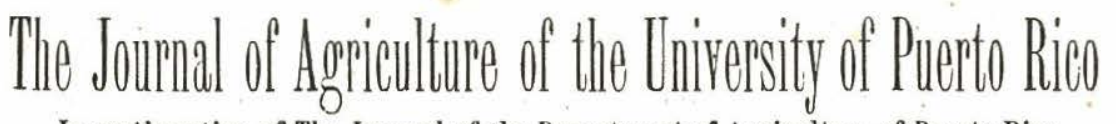

In continuation of The Journal of the Department of Agriculture of Puerto Rico

Published Quarterly: January, April, July and 0ctober of each year.

Melville T. Cook, Edror

\begin{tabular}{lll}
\hline Vol. XVIII & JANUARY-APrIL 1934 & No. 1-2. \\
\hline
\end{tabular}

\title{
PARTIAL BIBLIOGRAPHY OF VIRUS DISEASES OF PLANTS
}

\author{
By José I. ОтеRo, Librarian \\ and \\ Melville T. Cook, Plant Pathologist \\ Insular Experiment Station of Puerto Rico, \\ Río Piedras, Puerto Rico.
}

This bibliography was started independently by the two authors for their own personal uses. Upon learning that both were working on the same project, it was decided to combine our efforts and publish the combined manuseripts, hoping that the work would be of value to other students of virus diseases.

Many difficulties were met with in compiling this work. Some of which may be summarized as follows:

1. There are some errors in the many bibliographies that have been published in connection with the numerous papers on this subject. When these errors have come to our attention they have been corrected.

2. There are many short papers of little or no value but it has not always been possible to decide judiciously just which ones should be retained. No doubt we have made many injustices in deciding questions of this kind. Many anonymous papers and many Agricultural Experiment Station Bulletins of a popular character have been omitted. Reports of Directors of Agricultural Experiment Stations which do not include new data have been omitted in most cases. The publications of the Plant Disease Survey of the U. S. Department of Agriculture contains many records which are of value for estimates of losses and for geographical distribution in the United States. Most of these have been omitted unless they contain new records of hosts.

3. Many old papers which are of no value except as historical records have been omitted. Such papers are usually listed in recent publications on virus diseases. For example, the recent paper by Me Kay and Warner on "Historical Sketch of Tulip Mosaic or Breaking. The Oldest Known Plant Virus Disease" contains many 
historical record of this disease which have omitted from this bibliography.

4. Many errors have crept into the literature because the people making the citations did not understand the Spanish system of the names of persons. According to the Spanish system a person carries the names of the two parents; e.g. Rafael Menéndez Ramos. The first is his given name, the second is the name of his father and the third the name of his mother. He should be eited as Rafael Menéndez or as Rafael Menéndez Ramos, but never as R. M. Ramos as occasionally appears. We find him cited by both methods.

5 . There is some difference of opinion as to the cause of certain diseases; some workers believing them to be due to viruses and other workers believing them to be due to other causes. Among these diseases may be mentioned the diseases of pecans. The carnation yellows has not been proved to be a virus disease but the symptoms are of such character that we have inserted the references. Recent papers give evidence that the bitter pit of the apple is caused by a virus but our work on the bibliography was so far advanced that we have inserted only a few of the references.

The compilers intend to follow as closely as possible the following features in this bibliography, with the idea of making it more helpful to students and workers.

1. It is arranged alphabetically by authors and chronologically under the name of each author, taking always the senior author as guide in cases of more than one.

2. When it has been possible we have, used the authors' full names which enabled us to verify the correctness of many of the citations and avoid confusion and errors in authorship.

3. Titles appear first in the original language with translation into English in parenthesis. In some cases it has not been possible to obtain the original paper and in those cases the translated titles appear in parenthesis. Some titles appear only in the original languages. In cases of slavic or oriental languages the titles are translated into English.

4. When an article appears in more than one publication all except the first appear in parenthesis.

5 . We have not been able to see all the original papers on virus diseases of plants. Therefore, there are many which we have been unable to annotate.

The compilers do not claim that this bibliography is complete or without errors but if workers on virus diseases of plants will send their criticisms directly to the compilers, we will endeavor to publish 
a supplement in which corrections and additions will be made. All correspondence and all papers should be addressed to the junior author.

In the preparation of the manuscript we are very much indebted to the kind and valuable assistance of Dr. John Hendle Barnhart, of the New York Botanical Garden, who made many corrections and gave many suggestions, to Hon. Carlos E. Chardon, Chancellor of the University of Puerto Rico, Hon. Rafael Menéndez Ramos, Commissioner of Agriculture and Commerce, Mr. Rafael Fernández García, Ex-Director of the Insular Experiment Station of Puerto Rico, Mr. Francisco A. López Domínguez, Director of Insular Experiment Station of Puerto Rico, for their advice and moral support in the preparation and publication of this manuscript.

\section{Abbott, $\mathbf{E}$ [rnest] V[ictor], \& Townsend, Charles H[enry] T[yler]}

El mosaico de la caña de azúcar y su trasmisión. (Sugar cane mosaic and its transmission.) Perú Est. Expt. Agric. Soc. Nac. Agraria, Circ. 5, 10 p., 1928.

Popular discussion of the subject.

\section{\& Wolcott, G[eorge] $\mathbf{N}$ [orton]}

Mosaic of sugar cane in Perú. Science 69(1788): 381, 1929.

Account of the occurrence of mosaic disease of sugar cane in Pera and of the abundance of Aphis maidis Fitch. its insect vectors.

Diseases of economic plants in Perú. Phytopathology 19(7): 645-656, 1929.

Brief reference to mosaic of sugar cane.

A new host for sugar cane mosaic. Phytopathology (Abstract) $20(1): 109,1930$.

Refers to our "caña india" known in Perú as "caña brava", (Gynerium saggitatum). Growing in or near cane fields becomes infested with mosaic.

Adam, D. B.

Degeneration of potatoes. Virus diseases and their control. Jour. Dept. Agric. Victoria 30: 7-11, 1932.

Adams, J[ames] F[owler]

Lima bean and tomato mosaic. Delaware Agric. Expt. Sta. Circ. 14, 29 p., 1924.

\section{Adams, $R$ [ichard] L[aban]}

The California beet blight. Thesis submitted to the University of California for M. S. Degree, 1909. 


\section{Afzal Husain, III.}

Leaf-curl in cotton. Nature 124: 958, 1930.

Leaf-curl or crinkle in Sudan. Transmitted by an undetermined white fly (Aleurodidae). Empoasca devastans is considered a cause of one form of leaf crinkle.

\section{Agee, $\mathrm{H}$ [amilton] $\mathrm{P}$ [ope]}

Sugar cane diseases in the Hawaiian Islands. Proc. H. S. P. A. $37: 38-39,42-43,68-76,77-78,1917$.

Sugar cane diseases. Proc. H. S. P. A. 39:153-156, 1919.

Sugar cane diseases. H. S. P. A. Expt. Stat. Ann. Rpt. 1920: 18-21, 1920.

Resistance to diseases and adverse conditions by hardy sugar eane types. Louisiana Planter 72(2):75-76, 1924. (Australian Sugar Journ. 16:49-53, 1924.)

Report of the Committee in charge of the Experiment Station of the Hawaiian Sugar Producers' Association for the year ending September 1931. Inter. Sugar Journ. 34(399) : 101102, 1932.

Notes on several diseases of sugar cane among which it is stated that mosaic disease of sugar cane is still present, but declining. Its effects are unremitting and sometimes serious. Also states that the origin of chlorotic streak disease remains unsolved, though control methods are known.

\section{Ahr, J[oseph], Mayr, Chr., \& Worle}

Ernteliohe, knollensarbe und Blattrollkrankheit Kartoffeln in bezielung zu boden und Düngung. (Crop yield, tuber color, and leaf-roll of potato in relation to soil fertilizer.) Fuhling's Landw. Zeitg. 64(17-18) : 425-452, 1915.

\section{Ainsworth, G. C.}

Mosaic disease of the tomato. Expt. \& Res. Sta. Cheshunt Herts., 17th. Ann. Rpt. 1931: 42-43, 1932.

Juice from striped tomato plants innoculated into healthy plants produced mild mosaic in a majority of the cases. Stripe was produced in less than 40 per cent.

Virus disease investigations (a) Spotted wilt of tomatoes. (b) Mosaic and "stripe" disease of tomatoes. Expt. \& Res. Sta. Cheshunt Herts. Ann. Rpt. 18: 39-45, 1933. 
Account of observations made during 1932. Inoculation experiments and list of host plants and insect vectors. Some suggestions for control measures are given.

An investigtion of tomato virus diseases of the mosaic "stripe", streak group. Ann. Appl. Biol. 20(3) : 421-428, 1933.

Tomato mosaic was studied, described and compared to other types of virus diseases and spotted wilt.

\section{Alamo Ibarra, Roberto}

El mosaico, matizado o rayas amarillas de la caña de azúcar. (Mosaic, mottling or yellow stripe disease of sugar cane.) Venezuela Min. de Fomento, Pamphlet, 55 p., 1927.

Popular discussion of mosaic of sugar cane under Venezuelan conditions.

Alben, A. O., Cole, J[ohn] R., \& Lowis, R. D.

Chemical treatment of pecan rosette. Phytopathology 22(12) : 595-601, 1932.

The authors were able to improve old rosetted leaves and bring young ones back to normal by dipping or spraying them with a solution of ferric sulphate or ferric chloride, ranging in strength from 0.6 to 1 per cent. These findings would seem to indieate that peean rosette is a condition of iron chlorosis.

New development in treating pecan rosette with chemicals. 22(12) : 979-981, 1932.

A short paper giving the results of spraying trees with zine and iron salts. These results indicate that zine is an essential element for the healthy development of the trees.

\section{Alexander, Jerome}

Bacterial filters and filterable viruses. Science n.s. 65(1678): 207, 1927.

A very brief paper on bacterial filters and filterable viruses in general, in which the author discusses several types of filters. No reference to plant viruses.

\section{Alfaro, Julio}

A method of fighting the propagation of mosaic disease in sugar cane. Planter \& Sugar Manuf. 75(20) : 388-389, 1925. (Sugar 28(1) : 45, 1925. Trop. Agric. (Ceylon) 66(2) : 113114, 1925. El Mundo Azucarero 13(5): 150, 1925. Proc. Agric. Soc. Trinidad \& Tobago 25(2) : 437-439, 1925.)

Recommends the use of resistant varieties. 
Statement on mosaic control. Proc. Conf. Int. Soc. Sugar Cane Tech. (Havana) 2: 9199, 1927.

\section{Allard, H[arry] A[rdell]}

The mosaic disease of tobacco. Science n.s. 36(938) : 875-876, 1912.

The author's first paper on this subject, in which he gives a brief statement of the results of inoculation experiments and some of the symptoms. It is not produced by cutting back and not earried in the pollen. Also calls attention to the presence of aphids and suggests that the disease is probably due to a living active microorganism.

The mosaic disease of tobacco. U.S.D.A. Bull. 40, 33 p., 1914.

More extensive than the preceding. Gives special attention to cross inoculation experiments and to symptoms. Produced the disease by root inoculation and gives evidence that the disease is carried by $M a$. crosiphum tabaci Perg.

A review of the mosaic disease of tobacco, together with a bibliography of the most important contributions. Bull. Torrey Bot. Club 41(9) : 435-458, 1914.

An excellent review of the literature to date.

Distribution of the virus of the mosaic disease in capsules, filaments, anthers and pistils of affected plants. Journ. Agric. Res. 5(6) : 251-256, 1915.

Demonstrated that the virus penetrated to all parts of the plant except the seeds.

Effect of dilution upon the ineffectivity of the virus of the mosaic disease of tobacco. Journ. Agric. Res. 3(4):295299, 1915.

Gives effects of dilution of the virus. 1-1000 fully as effective as pure juice. 1-10,000 much less effective than pure juice. Believes the disease due to a parasite and not due to an enzyme.

Some properties of the virus of the mosaic disease of tobaceo. Journ. Agric. Res. 6(17) : 649-674, 1916.

A very thorough study of the properties of the virus with reference to chemicals and temperature. Believes that the disease is due to an ultramiscroscopic parasite. 
The mosaic disease of tomatoes and petunias. Phytopathology 6(4) : 328-335, 1916.

Gives the results of experiments with the mosaic disease of tomatoes and petunias which is in harmony with preceding studies on the mosaic of tobaceo.

A specific mosaic disease in Nicotiana viscosa distinct from mosaic of tobaceo. Journ. Agric. Res. 7(11) : 481-486, 1916.

The author gives evidence indicating that mosaic of $N$. viscosa is different from the ordinary mosaic of $N$. tabacum and the tomato (Lycopersicum esculentum.)

Further studies of the mosaic disease of tobaceo. Journ. Agric. Res. 10(12) : 615-632, 1917.

The active agent does not penetrate readily when sprayed on plants but does penetrate very slight wounds. Easily removed from hands by washing. Killed in soil by steam sterilization. Nicotiana glauca is susceptible. Is carried by Myzus persicae.

Mosaic disease of Phytolacca decandra. Phytopathology 8(1): 51-54, 1918.

Experimental evidence indicates that the mosaic of tobacco and Phytolacca decandra are different. The active agent overwinters in the plant.

Effects of various salts, acids, germicides, etc., upon the infectivity of the virus causing the mosaic disease of tobacco. Journ. Agric. Res. 13(12): 619-637. 1918.

Gives the results of extensive experiments to determine the effects of many ehemicals on the virus eausing mosaic of tobaceo.

Abnormalities in Nicotiana. Bot. Gaz. 65(2) : 175-185, 1918.

A description of abnormalities resulting from mosaic.

Some possible relationships of the mosaic diseases. Phytopathology 13(12) : 555-557, 1923.

A presentation of unsettled problem $\mathrm{S}$ in connection with the study of the mosaic disease.

\section{Allen, $\mathbf{F}[\mathrm{rank}] \mathrm{W}$ [isdom]}

Maturity and rate of ripening of Gravenstein apples in relation to bitter pit development. Amer. Soc. Hort. Sci. Proc. 28: 639-645, 1931.

Report of observations eorrelating maturity and bitter pit. Different treatments are reported. 


\section{Altson, $\mathbf{R}$ [alph] $\mathbf{A}[$ bbey]}

Report on a suspected outbreak of infectious mosaic disease among certain canes in the colony. Journ. Bd. Agric. British Guiana. 18(3) : 216-225, 1925. (Int. Sugar Jour. 27(318) : 293, 1925.)

Mosaic is the most serious problems in Jamaica. Gives record of losses.

\section{Amaral, Afranio de}

Pompen do mosaico. Bol. Agric. (Sao Paulo) Brasil 27:147156, 1926.

\section{Amos, J., Hatton, R[oland] G[eorge], Knight, R[obert] C[edric],} \& IMassee, A. IM.

Experiments in the transmission of reversion of black currant. East Malling Res. Sta. Ann. Rpt. Suppl. 15 : 43-46, 126-150, 1927.

The disease was produced by transferring big-bud mites from diseased to healthy plants, by grafting and inarehing.

Reversion of black currants. Its incidence and spread in the field in relation to possible control measures. Journ. Pomol. Hort. Sci. 6(3) : 167-183, 1927, (4) : 282-295, 1928.

The vector appears to be the big-bud mite Eriophyes ribis.

\section{Anderson}

Die wirkung der Viruskrankheiten der Kartoffel. (The effect of virus diseases of potatoes.) Prakt. Blät. Pflanzenbau u. Pflanzen. Schutz. 3:132-136, 1925.

Anderson, F. G.

The phony peach disease in Illinois. Trans. Illinois State Hort. Soc. 66: 214-217, 1933.

Popular description of the disease, warning to farmers to eradicate it. Has been known in Illinois since 1927.

\section{Anderson, $\mathrm{H}$ [arry] W[arren]}

Spinach mosaic. Illinois Acad. Sci. Trans. 15:130-140, 1922.

Control of bramble diseases. Kansas State Hort. Soc. Bienn. Rpt. 11:162-167, 1930.

\section{Anderson, James}

On the disease called the curl in potatoes, and some other particulars observed with regard to this plant. Bath Soc. paper 2d. ed. 4:92-107, 1792. 
Annaud, P. M., Chamberlain, J. C., Henderson, C. F., \& Waters, H. A. Movement of the beet leaf hopper in 1930 in Southern Idaho. U.S.D.A. Circ. 244, 24 p., 1932.

Although this paper is not on virus diseases, we included it, because of the great interest for the students on the subject, due to its close relationship.

\section{Anonymous}

Abridgment of several letters published by the Agricultural Society at Manchester in consequence of a premium offered for discovering the cause of the curled disease in potatoes. Letter No. V. Letters and Papers on agriculture, ete. Bath and West of England Society, Vol. I, 4th ed., p. 240-242; Letter IX p., 246; Letter XI, p. 248; Letter XV, p. 252; Letter XVI p., 252-253; Letter XVII, p. 254; Letter XVIII, P. 255, 1792 .

Historical value only.

On the curl in potatoes, with a radical cure. Ann. of Agric. 31, 1798.

Historical value only.

Plan for preventing the curl in potatoes. Farmer's Mag. 3: 13, 1802.

Historical value only.

Die blattrollkrankheit der Kartoffel. (The leaf roll disease of potato.) Zeitschr. Land. Versuchsw. Osterr. 14(7) : 911-915, 1911.

Gele strepenziekte. (Yellow stripe disease.) Meded. Arch. Java Suikerind. 20:1590-1593, 1912.

Plant disease in 1915. Phytopath. Lab. Willie Commelin Schotten 1915 , p. 18, 1916.

Mosaic disease of cucumber. Market Growers Journ. 19:34, 1916. (Amer. Flor. 46:1164, 1916.)

Mosaic disease of tobaceo and tomatoes. Gard. Chron. 3 ser. 59 (1526) : 172-173, 1916. 
(Dwarf disease of barley.) Journ. Plant. Protec. 3: 937-942, 1916.

(Experiments for the control of the dwarf disease of potatoes.) Okayama Agric. Expt. Sta. Ann. Rpts. 1915: 143-144, 1916; 1916 : 183-184, 1917.

(On the stripe disease of the rice plant.) Imp. Agric. Expt. Sta. Ann. Rpt. 1913: 15-41, 1917.

Plant diseases in Ontario. Ontario Agric. Col. \& Expt. Farm 43 : 20-31, 1917.

New disease causes alarm. Facts About Sugar 6:426, 1918.

Sugar cane leaf stripe disease. H.S.P.A. Proc. $39: 196-202$, 1919.

Louisiana Planter 63: 82, 1919.

(Phytopathological review.) Agric. Colon. (Italy) 23(9) : 356362, 1919.

Report of the conference on sweet potato problems and on diseases of cotton, corn and tomatoes. Washington: Advisory Bd. Amer. Plant Path., Amer. Phytopath. Soc. 16 p., 1919.

(Potato diseases.) Meded. Phytopath. Dienst (Wageningen) $6: 19,1919$.

Mosaic disease as a factor influencing yield. Potato Mag. 2 (5) : 11, 27, 1919.

The mosaic disease. Louisiana Planter 63:253-255, 1919.

Porto Rico fights cane mottling disease. Sugar 22:208-210, 1920.

Mosaic or mottling disease. Agric. News (Barbados) 19: 245, 1920. 
Mosaic disease in potatoes. Agric. Gaz. Canada 7:557-558, 1920.

The cause of the sugar cane mottled or mosaic disease. Louisiana Planter 65 : 195-196, 1920.

Potato leaf curl. Journ. Min. Agric. (London) 27 : 287-289, 1920.

Rajeunissement et perfectionnement de la pomme de terre. (Rejuvenescence and perfection of the potato.) Journ. Agric. Pract. Jan. 1, 1920.

La "filosité". Journ. Agric. Pract. April 1, 1920.

Florida Plant Board. Third Bienn. Rept. p. 67-71, 89-90, 1921.

Mosaic disease in Barbados. Agric. News (Barbados) 20:15, 1921.

Mosaic disease-susceptible and immune varieties. Journ. Jamaica Agric. Soc. 25:427-429, 1921.

Mosaic disease. Expt. \& Res. Sta. Cheshunt Herst., Ann. Rpt. $7: 41,1921$.

Mosaic disease of sugar cane and control measures. Louisiana Planter 66(12);186-187, 1921.

Yellow stripe disease investigations (Progress report). Int. Sugar Journ. 23 : 453-454, 1921.

(Varietal susceptibility of the potato to the curly dwarf.) Hokkaido Agric. Expt. Sta. Ann. Rpts. 1915 : 20, 1916; 1916: 20, 1917; 1919: 65-66, 1921.

The mosaic disease of sugar cane in Trinidad. Int. Sugar Journ. 23 : 74-75, 1921.

Fiji disease controlled by seed selection. Sugar Cent. \& Planters' News. 2(8) : 335-336, 1921. 
The Fiji "disease" of sugar cane. Journ. Dept. Agric. Union

South Africa. 2:554-556, 1921.

Mosaic disease of sugar cane. Florida Plant Bd. Bienn. Rpt. 1919-20, 3:67-71, 89-96, 1921.

Notes on the Government action to prevent the spread of the disease and data of losses.

Mosaic disease of sugar eane. Louisiana Planter 69(25):442443, 1922.

Review of Kunkel and Lyon's work. Conclusions, given control measures.

Plant diseases: Three major cane diseases. Agric. News (Barbados) $21: 62,1922$.

Sugar cane mosaic infested areas. Florida State Plant Bd. Circ. 44, 2p, 1922.

Transmission of sugar cane mosaic by aphids. West Indian Committee, Circ. 37:521, 1922.

Leaf curl and mosaic disease of potato and their relation to deterioration in yield. Fruit Grower \& Veg. Trade Journ. (London) 41(19) : 529-530, 1922.

Louisiana Planter 69(25):442-443, 19:2.

Report of the Department of Agriculture, Barbados, for the financial year 1921-22, p., 19. (Rev. Appl. Mycol. 2: 260-261, 1922.)

Mosaic disease of potatoes. Kentucky Agric. Expt. Sta. Ann. Rpt. 1921: 45, 1922.

Bunchy top in bananas. Queensland Agric. Journ. 18(5) : 307, 368-369, 1922.

The author discusses a treatment with sulphur and lime.

Mosaic disease of sugar cane. Louisiana Planter 69:442-443, 1922.

A popular paper with special attention to Kunkel's work in Hawaii. 
Banana bunchy top disease. Queensland Agric. Journ. 19(1): 32-33, 1923.

A discussion of cause and control. Apparently written before the cause was known.

Degeneration of the potato. Gard. Chron. 73:25-26, 1923.

Effect of selection of "seed" on the yield of the potato crop. (Leaf roll disease) Journ. Dept. Agric. Ireland 22:378-380, 1923.

Leaf-roll and mosaic, two important diseases of the potato. Ireland Dept. Agric. \& Tech. Instr. Spec. Leaflet 24, 4 p., 1923.

Mosaic disease in potatoes. Kentucky Agric. Expt. Sta. Ann. Rpt. 1922 : 37-38, 1923.

Mosaic disease. Gard. Chron. 73:345, 1923.

New peanut disease (rosette). Journ. Dept. Agric. South Afríca $7: 191,1923$. A record.

The study in degeneracy in potatoes. Nebraska Agric. Expt. Sta. Ann. Rpt. 1922 : 10-11, 1923.

Virus diseases in plants. Gard. Chron. 74:168, 1923.

Virus diseases of plants. Nature 111:551, 1923.

Sugar and mosaic disease of canes. Journ. Jamaica Agric. Soc. 27 : 864-869, 1923.

A popular review of the subject.

Treatment of mosaic in Natal. Strong views of the Government Entomologist. South African Sugar Journ. 7: 745-747, 1923.

Mosaic disease in Jamaica. West Indian Committee Circ. 38 (653) : 435-436, 1923. 
Verslag over het jaar 1922 Departement van Landbouw in Suriname. (Report of the Department of Agriculture, Suriname, for the year 1922,) p. 106, 1923.

Press cake and mosaic. Sugar Cent. \& Plant. News 4: 84, 1923. (Int. Sugar Journ. 25:315, 1923.)

A mosaic immune cane. Sugar Cent. \& Plant. News 4: 83, 84, 1923. (Int. Sugar Journ. 25: 322, 1923.)

Mosaic disease. Agric. Journ. India 19:198-201, 1923.

Louisiana Planter 70(6): 103, 1923.

El Mundo Azucarero 10(6) : 162-163, 1923. La enfermedad moteada de la caña. (The mottle disease of sugar cane.)

Mosaic disease. Gard. Chron. 73:345, 1923.

On insect transmission of mosaic, especially in Java. Int. Sugar Journ. 25: 346-351, 1923.

Virus diseases of plants. Nature $112: 293,1923$.

The mosaic disease of sugar cane order 1923. Journ. Jamaica Agric. Soc. $28: 27,1924$.

Jahresbericht der Preussischen Landwirtschaftlichen Versuchs und Forschungsanstalten zu Landsberg-an-Warthe Jahrgang 1923-24. (Annual Report of the Prussian Agricultural Experiment and Research Station at Landsberg-an-der-Warthe, 1923-24.) Landw. Jahb. 60:127-260, 1924.

Plant diseases, South Africa. Journ. Union So. Africa Dept. Agric. 8(1) 9, 1924.

Tobacco mosaic. Mauritius Dept. Agric. Ann. Rpt. 1923: 1011, 1924.

Mosaic disease eradication campaign. South African Sugar Journ. 8(7) : 523-524, 1924. 
The Uba cane controversy. Australian Sugar Journ. 16:392, 1924.

Precautions against diseases. Australian Sugar Journ. 16: 504 505, 1924.

El Dr. Cross y el mosaico de la eaña en Cuba. (Dr. Cross and mosaic disease of sugar cane in Cuba.) Rev. Agric. Com. \& Trab. Cuba 7(3) : 10-11, 1924.

Controversial.

Mosaic resistant varieties of cane to be grown by Louisiana planters in Florida. Louisiana Planter 72:359, 1924.

Natal Acts to stop mosaic. Facts About Sugar 19:450, 1924.

Experimental Agriculture in Jamaica. Int. Sugar Journ. 26: 274-276, 1924.

Cane seedling work in Hawaii. Australian Sugar Journ. 16: 163-164, 1924.

From all sources. So. African Sugar Journ. 8:461, 1924.

The Natal Planters' Union. Annual General Meeting. So. African Sugar Journ. 8: 256-257, 259, 261, 263, 267, 1924.

Mosaic disease in Natal. Important communications from world's experts. South African Sugar Journ. 7(4) : 269-271, 1924.

Verslag over het jaar 1923. Dept. van Landbouw in Suriname, 114 p., 1924.

This report contains information about the sieve tubes (Phloemnecrosis) of coffee trees and probable insect carriers.

Work in connection with insect and fungus pests and their control. Antigua Dept. Agric. Rpt. 1922-23:7-8, 1924. (Rev. Appl. Mycol. 4:59-60, 1925.) 
Mosaic cane disease in America. Australian Sugar Journ. 16: $420,1924$.

Blattrollkrankheit der Kartoffel. Krög. Ratg. Obst-u. Gartenb. 4. No. 3, 1924.

Bunchy top control. Queensland Agric. Journ. 21(2) : 152-153, 1924.

Popular.

"Bunchy top" in bananas, its Queensland history. Queensland Agric. Journ. 21(3) : 254, 1924

Mosaic disease. Agric. Journ. India 19:198-201, 1924.

A brief discussion of papers read at the Cambridge meeting of the American Association for the Advancement of Science, 1922-1923.

Mosaic disease in Natal. Proposal for eradication. So. African Sugar Journ. 7:808, 1923; 8:269-271, 523-524, 1924.

Serious nature of cane diseases. So. African Sugar Journ. 8: $535,1924$.

Seed potatoes and virus diseases. Gard. Chron. 74: 85, 1925.

A study in degeneracy in potatoes (Spindle tuber). Nebraska Agric. Expt. Sta. Ann. Rpt. 1924: 30-31, 1925.

Mosaic disease. Trop. Agric. (Trinidad) 2:30, 1925.

A review of Rosenfeld's paper "The beneficial aspect of mosaic disease.

Behaviour of some varieties of cane to mosaic disease in the Hawaiian Islands. Trop. Agric. (Trinidad) 2:132-134, 1925. A review of Kunkel's work in Hawaii.

Leaf roll, mosaic and related diseases of the potato. Parts 1 and 2. Scottish Journ. Agric. 8(1) : 44-55, (2)176-189, 1925.

Mosaic disease. Journ. Jamaica Agric. Soc. 29:81, 1925. A brief note containing lists of susceptible hosts. 
Mosaic disease inspection. Barbados Dept. Agric. Ann. Rpt. 1925 : 8, 1925.

A record of inspection for sugar cane mosaic.

Mosaikkrankheit auf Kuba. (Mosaic disease in Cuba.) Deutsche, Zucker-industri $50: 1246,1925$.

Selection of sugar cane in Louisiana for tolerance to mosaic disease. Trop. Agric. (Trinidad) 2:150, 1925.

A review of a paper by Edgerton and Taggart in the Planter \& Sugar Manufacturer for March 7, 1925.

Research on diseases of plants (mosaic). Trop. Agric. (Trinidad) 2:200, 1925 .

Mosaic disease. Journ. Jamaica Agric. Soc. 29: 81, 1925.

Mosaic disease of sugar cane. Journ. Jamaica Agric. Soc. 29: 144, 1925.

Enfermedad del mosaico. Extracto del informe de la Comimisión de Matanzas. (Mosaic disease. Summary of the Matanzas Commission Report.) Rev. Agric. Com. \& Trab. Cuba $7(8):$ 25-27, 1925.

Plant Pathology. Idaho Agric. Expt. Sta. Bull. 135, 1925.

Rosette disease of peanuts. Journ. Union of So. Africa Dept. Agric. 11(1) : 10, 1925.

Mosaic disease. Jamaica Dept. Agric. Ann. Rpt. 1925.

South African Sugar Association importation of sugar cane varieties. So. African Sugar Journ. 9:455, 1925.

The Uba streak disease in Natal. So. Africa Sugar Journ. 9: 665, 1925. 
Twenty-fifth Annual Report of the Bureau of Agriculture, Philippine Islands, for the fiscal year ending December 31, 1925, 123 p., 1926.

Notes of studies on mosaic of Musa textiles, Agave Cantala and A. sisalana.

Verslagen, 5-Aflevering. Verslangen der Vergaderingen van de Vereeniging van Adviseurs bij de Java-Suikerindustrie, Verslag der Vergadering van de Landbouwkudige Sectie op Woensdag, 5 Augustus 1925. (Reports, 5th Series. Reports of the meetings of the Associations of Advisors to the Java Sugar Industry. Report of the meeting of the Agricultural Section on Wednesday, August 5, 1925.) Arch. Java Suikerind. 33(4) : 189-244, 1925. (Rev. Appl. Mycol. 5(3) : 186187, 1926.)

Contains data on Aphis maidis.

Work in connection with insect and fungus pests and their control. St. Kitts-Nevis Dept. Agric. Rpt. 1923-24: 5, 33, 1925. (Rev. Appl. Mycol. 4(11) : 704, 1926.)

Mosaic disease inspection. Barbados Dept. Agric. 1924-25:8, 1925. (Rev. Appl. Mycol. 5(3): 189, 1926.)

Spread of mosaic in sugar cane. Australian Sugar Journ. 18 (3) : 154, 1926.

Bunchy top (of bananas). Queensland Agric. Journ. 25: 259268, 1926.

Mosaic disease in Jamaica. Sugar 28(1):30, 1926.

A review of a circular issued by the Department of Agriculture of Jamaica.

El mosaico en Java. (Mosaic in Java.) Sugar 28(1) : 45, 1926.

Indexing of potatoes for mosaic. Wisconsin Agric. Expt. Sta. Bull. 388, 45 p., 1926.

A simple method of inoculating potatoes with spindle tuber disease (id. mosaic and leaf roll). Phytopathology 16:223, 1926. 
Work with economic insects in Wisconsin. Wisconsin Agric.

Expt. Sta. Bull. 388: 60-75, 1926.

Incidence of bunchy top disease of plantains in Ceylon. Trop. Agric. (Ceylon) 66(1): 9-12, 1926.

Bunchy top in bananas: cause and nature of the disease. Trop. Agric. (Ceylon) 66(1): 12-20, 1926.

(A survey of the bean mosaic.) Hakkaido Agric. Expt. Sta. Ann. Rpts. 1921: 106-109, 1923 ; 1922:113-126, 1924; 1923; 146-162, 1926.

Bunchy top in bananas. The nature of the disease and the measures recommended for its control. Agric. Gaz. N. S. Wales $37(8)$ : 603-612, (9) : 697-705, 1926.

A popular review of our knowledge of this subject.

Bunchy top-What it is, how to detect it, what to do. Queensland Agric. Journ. 25(3) : 259-268, 1926.

Popular.

Bureau of Sugar Experiment Station. Fiji disease (Northiella sacchari). Queensland Agric. Journ. 26:280-281, 1926.

Popular.

Bunchy top-departamental action. Queensland Agric. Journ. 26 : 297-298, 1926.

A report on methods of eradication and control.

Mosaico da canna de assucar. (Sugar cane mosaic.) Min. Agric. Indus. Com. Inst. Biol. Defensa Agric. Río de Janeiro (Brasil) Circ. Serv. Phytop. 11 p., 1926.

Rosette of apricot and plum trees. Journ. Dept. Agric. So. Africa 12 : 193-194, 1926.

A record of these diseases.

Su di un mezzo di diffussione della malattia del mosaico. Western Tobaceo Journ. (Cincinnati) 53, No. 52, 1926. 
Results of cane selection in Porto Rico. (Introduction of improved varieties credited with increasing annual value crop by $\$ 13,000,000)$. Facts About Sugar 21(40):950, 1926.

Mosaic control. Facts About Sugar 21(40): 940, 1926.

Agricultural Department to study curly top. Facts About Sugar 21(26): 617, 1926.

To hunt immune canes. Facts About Sugar 22(20) : 487, 1927.

Natal y Zululandia establecen el control de la enfermedad mosaico de la caña. (Natal and Zululand establish the control of sugar-cane mosaic disease.) Mundo Azucarero 15(4): 102, 1927.

Curly top of sugar beet. New Mexico Agric. Expt. Sta. Ann. Rpt. 1928-29.

Mosaikfäule der Rübe. (The mosaic rot of beet.) D. Schwäb. Bauersmann 12, No. 6, 1927.

New way to diagnose mosaic disease. Wisconsin Agric. Expt. Sta. Bull. 405 : 114-116, 1927.

Studies on the mosaic disease of the tomato. Indiana Agric. Expt. Sta. Ann. Rpt. 1927 : 53-54, 1927.

Sugar cane. Prohibition concerning mosaic disease. Farming in South Africa 2:228, 1927.

Virus diseases of potatoes. Gard. Chron. 81:277-278, 1927.

Disease control in Hawaii. Eye spot and mosaic reduced in past year by control measures. Facts About Sugar 23:657, 1928.

Popular.

Rosette disease of peanuts. Farming in South Africa 2:543, 1928. 
"Breaking" in tulips. Gard. Chron. 83: 84, 1928.

Die Blatrollkrankheit der Kartoffel. (Leaf roll disease of potato.) D. Kartoffelbau 12:100-101, 1928.

Leaf-roll and mosaic diseases of the potato. Dublin Dept. Agric. Leaflet 29, 7 p., 1928.

Plant pathology. Idaho Agric. Expt. Sta. Bull. 164:34-37, 1928.

Brief account on potato rugose mosaic, leaf roll, spindle tuber and mild mosaic elimination, bean mosaic, curly top and mosaic of beets.

Plant disease investigations in Kentucky. Kentucky Agric. Expt. Sta. Ann. Rpt. p. 13-16, 30-31, 1928.

Studies on tobaceo and eucumber mosaic, and tomato streak.

Division of botany. New York. Agric. Expt. Sta. Am. Rpt. 1927-28, 47: 32-38, 1928.

Raspberry yellow mosaic, mild mosaic and streak.

California Agric. Expt. Sta. Ann. Rpt. 1927-28: 97, 1929.

Notes on buckskin and crinkle of cherries, little leaf or yellows of peach, apricot and plums.

(A survey on the distribution of plant diseases and insect pests.) Japan Dept. Agric. \& Forest., Br. Agric. 2, 431 p., 1929.

Discussion on "Ultramicroscopic viruses infecting animals and plants." Roy. Soc. London, Proc. ser. B, 104(B733) : 537560, 1929. (Nature 123(3094): Feb. 23, 1929.)

Plant pathology at the Iowa Station. Iowa Agric. Expt. Sta. Ann. Rpt. 1929 : 27-28, 39-41, 60-62, 1929.

Why does potato seed run out. New Hampshire Agric. Expt. Sta. Bull. 235 : 8, 1929.

Bunchy top. Fruit World, Australasia 30:114, 1929.

Virus diseases of the potato. Gard. Chron. 86:197, 1929. 
Potato virus diseases: Leaf roll. Gard. Chron. 86:217, 1929.

Ground nuts rosette disease. Trop. Agric. (Trinidad) 6:111, 1929.

Quoted from Nature 122: 938, 1929.

Virus diseases of the potato.- 1 . The diseases and their symptoms. Gard. Chron. 87: 505, 1930.

Virus diseases of the potato. - 2 . The role of insects as diseminators of virus diseases. Gard. Chron. 88:1, 1930.

Virus diseases of potato. Gard. Chron. 88:21, 1930.

Agricultural Experiments 1929. New Hampshire Agric. Expt. Sta. Bull. 250, 1930.

Notes on potato mosaic.

Administration Report of the Forest Department of the Madras Precidency for the year ending March 31st, 1929. 2:345, 1930. (Rev. Appl. Mycol. 9:566, 1930.)

Bureau of Agricultural Industry. Michigan Dept. Agric. 4th Bienn. Rpt. 1929 : 19-57, 1930.

The "Red structure" a virus diseases of peaches is reported to be spread to non-infested counties.

Diseases of plants. Kansas Agric. Expt. Sta. Bienn. Rpt. 1929-30: 97-103, 1930.

Mosaic disease of the sugar beet. Plant Breeding Dept. Union Sugar Ind. Kieff, 286 p., 1930.

Phony disease of peach. U.S.D.A., Br. Plant Indus. Plant Disease Reporter 14(15):148-149, 1930.

Plant pathology at the Station of Iowa. Iowa Agric. Expt. Sta. Ann. Rpt. 1930: 23-26, 54-55, 1930.

Von der Mosaikkrankheit des Spinats. (With the mosaic dis. ease of spinach.) Deutsche. Gärtner-Zeitg. 28:76, 1930. 
Department of Botany and Plant Pathology. Oregon Agric. Expt. Sta. Director's Bienn. Rpt. 1926-28 : 78-82, 1930.

Notes are given on several plant diseases of the mosaic type.

Division of Botany. New York (Geneva) Agric. Expt. Sta. Ann. Rpt. $1930: 40-50,1930$.

Very interesting notes on potato leaf-roll, mosaic of Refugee beans and different virus diseases of raspberries.

Tobaceo and potato virus diseases. Kentucky Agric. Expt. Sta. Ann. Rpt. 42: 52, 1930.

Jahresbericht der Preussichen Landwirtschaflichen in Landsberg (Warthe) Jahrgang 1929-30. (Annual Report of the Prussian Agrieultural \$isprimental and Research Institute at Landsberg (Warthe) Year 1929-30.) Land. Jahrb. Suppl. 72(1) : 1-140, 1930.

Zpráva o Skolivych cinitelich kulturnich rostlin v Republic Ceskoslovenské v roce 1929. (Report on the agencies injurious to cultivated plants in the Republic of Czecho-Slovakia in 1929.) Ochrana Rostlin 10(1-2) : 1-55, 1930.

Vine mosaic notes.

Wie bekämft man die Mosaikkrankheit der Rübe? Sowjetsky Sacher No. 6/7, 1930.

Plant pathology at the New York State Station. New York State Agric. Expt. Sta. Ann. Rpt. p. 40-47, 1930.

Brief notes on bean, raspherry, potato and crucifer virus diseases.

Plant pathology at the Wisconsin Station. Wisconsin Agric. Expt. Sta. Bull. 410:40-42, 56-58, 1930.

Account on some virus diseases of different plants.

Physico-chemical study of viruses. Indiana Expt. Sta. Ann. Rpt. p. 52-53, 1931.

Report of physico-chemical studies of viruses in cooperation with the Department of Botany. 
Achtung auf Schwarzbeinigheit, Mosaikkrankheit und Blattroilkrankheit. Osterr. Zeitschr. Kartoffelb. p. 66-67, 1931.

Die neueren Untersuchungen von Quanjer über die Ursache der Blattrollkrankheit der Kartoffell und der Sorauer'sche Standpunkt. (The new investigations of Quanjer about the cause of the potato leaf-roll disease and the stand-point of Sorauer.) Ztschr. f. Pflanzenkrank. 17:244-253, 1931.

Investigations on the spike disease of sandal. Bangalore, Indian Inst. Sci. 16 p., 1931.

Proceedings of the conference on the spike-disease of sandal at the Indian Institute of Science. Bangalore, Indian Forest. 57 : 215-283, 1931.

Virus diseases of plants. Gard. Chron. 90:81, 1931.

Virus diseases of the potato and their control. Scotland Dept. Agric. Leaflet 60:11 p., 1931.

Popular notes.

Aphides and "breaking"' in tulips. Gard. Chron. 90:1, 1931.

Purification of plant viruses. Science n.s. 76(1968):9-10, 1932.

A brief review of C. G. Vinson recent work.

The enzyme theory of virus diseases. Science Suppl. 76:9-10, 1932.

A brief review of C. G. Vinson's work.

Investigations of the spike disease of Sandal. Indian Inst. Sci. Bangalore, No. 4, 16 p., No. 5, 18 p., 1932.

Virus diseases of tobacco in Nyasaland. Nyasaland Dept. Agric. Bull. n. s. 15 p., 1932.

"Katahdin," a new variety of mosaic resistant potato. Science n.s. $75(1938): 12,1932$. 
Investigations of the seventh spike conference held at the Indian Institute of Science, Bangalore., on 25th April, 1932. Indian For. 58(9): 489-495, 1932.

Insect transmission of spike disease. Nature 132(3337):592593, 1933.

Note of a fortheoming paper by M. Appana and C. Dover on the subject.

Varietal introduction in Puerto Rico and the Philippines. Internat. Sugar Journ. 35(415) : 257-258, 1933.

Brief review of a lecture by C. E. Chardon and a paper by J. J. Mirasol on the effect of the introduction of immune or resistant sugar cane varieties to mosaic disease into Puerto Rico and the Philippine Islands, respectively.

\section{Anstead, R[udolp] D[avid]}

Report on the operations of the Department of Agriculture Madras Precidency for the official year 1923-24. Report 41, 1924.

Mosaic disease. Madras Dept. Agric. Bull. 92:13, 1928.

\section{Appel, [Friedrich Carl Louis] Otto}

Zur Kenntnis des Wundverschluss bei den Kartoffeln. Ber. Deutsch Bot. Geb. 24:118-122. 1906.

Ueber die Blattrollkrankheit der Kartoffel. (On the leaf roll disease of potatoes.) Mitt. Kais. Biol. Anst. f. Land-u Forstw. 2:10, 1906.

Die Blattrollkrankheit der Kartoffel. (Potato leaf-roll disease.) Biol. Anst. Land-und Forst. Flugblatt 42:4, 1907.

Aus der Geschichte der Kartoffelkrankheiten. (History of the potato diseases.) Biol. Anst. Land-und Forst. Heft 5:378, 1907.

\section{\& Kreitz, Wilhelm}

Der Derseitige Stand unserer Kenntnisse von den Kartoffelkrankheiten und ihrer Bekämpfung. Mitt. Kaiserliche Biol. Anst. fur Land-und Forst. Heft 5, 31 p., 1907. 
(Annual report of the Association for Applied Botany.) Jahresb. Ver Angew. Bot. 6(42) : 294, 1908.

(Notes on the leaf-roll disease of potatoes.) Jahresb. ver. Angew. Bot. 6:259-265, 1908.

\section{\& Kreitz, Wilhelm}

Die hauptsächlichsten Kartoffelkrankheiten. Illus. Landw. Zli. $28: 150-151,1908$.

Die Beschaffung von Saatkartoffeln in Rücksicht auf die Blattroll-und Ringkrankheit. Jahrb. D. Landw. Ges. 23:161, 1908.

Die Kartoffelernte in 1908. Und die Blattrollkrankheit. (The potato crop in 1908 and the leaf-roll disease.) Ill. Landw Zeitung. 29:176-178, 1909.

\section{\& Kreitz, Wilhelm}

Die Blattrollkrankheit der Kartoffel. (The leaf-roll disease of potato.) Mitt. Biol. Anst. Land-und Forest. 8:15-17, 1909.

Die Blattrollkrankheit der Kartoffel. (The leaf-roll disease of potato.) Biol. Anst. f. Land-und Forst. Flugblatt 3(42):2, 1909.

\section{\& Schlumberger, Otto}

Die Blattrollkrankheit und unsere Kartoffelernten. (Leaf-roll disease and our potato erop.) Arbeiten der Deutschen LandWirst. Gesell. 190, 102 p., 1911.

\&

Zur Kenntnis der Blattrollkrankheit der Kartoffel. (On the study of leaf roll disease of potato.) Mitt. Kais. Biol. Anst. Land. u. Forstw. 11:13, 1911.

\&

Die Blattrollkrankheit der Kartoffel. (Leaf-roll disease of potato.) Mitt. Kaiserliche Biol. Anst. Land-und Forst. 12: 14-15, 1912.

Leaf roll disease of potato. Phytopathology 5(3):139-148, 1915. 
This paper is a very general discussion of the virus diseases of the potato, giving symptoms and other information which was written before the full development of the virus theory.

\section{\& Schlumberger, Otto}

Die Blattrollkrankheit der Kartoffel. (The leaf roll disease of potato.) Mitt. Biol. Anst. Land-und Forst. 15: 8-11, 1916.

Die Mosaikkrankheit der Kartoffel. (The mosaic disease of potato.) Deutsche Landw. Presse 51:527, 1924.

Die zur zeit wichtigsten Kartoffelkrankheiten. (The most important potato diseases of the present day.) Deutsch. Landw. Presse 52(7) : 75-76, 1925.

Gelfleckigkeit der Kartoffelstanden. (Yellow spotting of potato foliage.) Deutsche Landw. Presse 53(17): 209, 1926.

A deseription of the diseased plants.

Neue Erfahrungen und Forschungen auf dem Gebiete der Rübenkrankheiten. (New experiments and investigations in the beet disease field.) Deutsche Zuckerindust. 31: 845-849, 1929. (Rev. Appl. Mycol. 9(3): 153, 1930.)

\section{\& Schlumberger, Otto}

Die Blattrollkrankheit und unsere Kartoffeleruten. (Leaf-roll disease and our potato crop.)3 cartes, 102 p., Berlin, Paul Parey, 1931.

Vitality and vitality determination in potatoes. Phytopathology 24(5) : 482-494, 1934.

Brief introductory, general considerations about degeneration diseases of potatoes. Discussion of Bechhold and Erbe copper method and Watenberg \& Hey's potentriometric method of evaluation of cropping values.

\section{Appleman, Charles O[rval]}

Special growth-promoting substances and correlation. Science n. s. $48: 319-320,1918$.

\section{Arango, Rodolfo}

La enfermedad de las rayas amarillas, o mosaico de la caña de azúcar. (The yellow stripe disease or mosaic of sugar cane.) La Hacienda 16(4): 106-109, 1921.

A popular discussion of the subject. 


\section{Arceneaux, G[eorge], Stockes, I. F. Bisland, R. B., \& Krumbhaar, C. C.}

Variety tests of sugarcanes in Louisiana during the crops year 1931-32. U.S.D.A. Circ. 298, 31 p., 1933.

The great loss $(\$ 100,000,000)$ in the last ten years due to mosaic disease of sugar cane in Louisiana is attributed by the authors to the absence of resistant varieties adapted to local conditions. Other valuable data in regard to mosaic resistance of some sugar-cane varieties under Louisiana conditions is given.

\section{Arendsen Hein, S. A.}

(Information in regard to the yellow stripe disease of sugar cane.) Arch. Java Suikerind. 1:215-216, 1893.

Gele Strepenziekte (Yellow stripe disease.) Arch. Java Suikerind. 1:205, 1894.

\section{\& Wakker, Jan $\mathrm{H}$ [endrik]}

Enquete amstret de gele strepenziekte. (Symposium concerning yellow stripe disease.) Arch. Java Suikerind. 2: 81-84, 1894.

Hypothesen en ervaring omtrent de sereh ziekte. (Hypothesis and experiences about the sereh disease.) De Indische Mercuur, Amsterdam, 1905.

\section{Arthur, J[ohn] IMIorris ]}

Killing of plant tissue and mosaic virus as related to wavelength in the ultra-violet region. Amer. Journ. Bot. (Abstract) $15: 623,1928$.

\section{, \& Newell, J[ohn] M[ackintosh]}

The killing of plant tissue and the inactivation of tobacco mosaic virus by ultra-violet radiation. Amer. Journ. Bot. 16(5) : 338-353, 1929. (Contr. Boyce Thompson Inst. Plant Res. 2: $143-158,1929$.

This paper gives the results of experimental work to determine the effect of ultra-violet radiation on both host and mosaic virus.

\section{Arthur, J[oseph] C[harles], \& Bolley, H[enry] L[uke].}

Bacteriosis of carnation. Indiana Agric. Expt. Station. Bull. 59, 40 p., 1896.

This is the so-called yellows disease of carnations which is probably a virus disease. The author at first believed it to be due to bacteria and later to insects, such as aphids, thrips and red spider. 


\section{Artschwager, Ernst F[riedrich]}

Histological studies on potato leaf-roll. Journ. Agric. Res. 15: 559-570, 1918.

Typical leaf roll plants do not always show necrotic conditions. Plants affected with other troubles may show pathological changes in the phloem. Gives a very thorough discussion of phloem necrosis.

Occurrence of phloem necrosis in leaf roll tubers. Phytopathology 12(4) : 193-194, 1922.

The necrosis increases with the growth of the shoots.

Occurrence and significance of phloem necrosis in the Irish potato. Journ. Agric. Res. 24(3) : 237-245, 1923.

Gives the results of histological studies on plants with this disease.

Studies on the potato tuber. Journ. Agric. Res. 27(11) : 810835, 1924.

The author does not discuss virus diseases but the paper is of: interest to students of these maladies because of the explanation of. peculiar protozoan-like struetures of cytoplasmic origin which some. workers have believed to be protozoa and the causes of virus diseases.

\section{Ashby, S[ydney] $\mathbf{F}$ [rancis]}

Leaf roll disease of Irish potatoes. Jamaica Journ. Agric. Soc. 23: 44-46, 1919.

A comment on Wortley's paper (Phytopathology 8: 507-529, 1918.) The author recommends preventive methods especially roguing.

Mottling of yellow stripe disease of sugar cane. Jamaica Journ. Agric. Soc. 23: 344-347, 1919.

A compiled account of this disease now prevalent in Puerto Rico and Southern United States. Deseription of damage, symptoms, distribution, varieties attacked and control means are given. The disease is not known in Jamaica.

Diseases of plants-Sugar cane. Jamaica Dept. Agric. Ann. Rpt. 1920 : 26, 1920.

Brief reference to sugar eane mosaic. First record in Jamaica.

The mosaic, mottling or yellow stripe disease of sugar cane. Jamaica Dept. Agric. Leaflet, 13 p., 1920.

Popular. 
Plant diseases.-The mosaic disease of cane. Agric. News (Barbados) 20(496) : 142-143, 1921.

A popular discussion of sugar cane mosaic.

A case of simple cure. Trop. Agric. (Trinidad) 1(4) : 62-63, 1924.

A review of Dr. G. Wilbrink's paper in Areh. Java Suikerindus. 1: in 1923.

Obscure plant diseases of widespread occurrence. Sugar cane mosaic. Report of Proc. Imp. Conf. London p. 122-131, 1924. (Rev. Appl. Mycol. 4(7): 442, 1925.)

Behavior of some varieties of cane to mosaic disease in the Hawaiian Islands. Trop. Agric. (Trinidad) 2(6):132-134, 1925. (Rev. Appl. Mycol. 5(1) : 3, 1926.)

A review.

Three serious cane diseases not yet reported from the British West Indies. Proc. Ninth West Indian Agric. Conf. p. 8489, 1925 .

\section{Asunción, Silvestre}

Mosaic disease and its effect in the sugar industry in the Philippine Islands. Philippine Agric. Rev. 18(1):33-38, 1925. (Sugar 28(2) : 79-80, 1926.)

Sugar-cane growing in the Philippines. Methods of cultivation and fertilization, varieties of sugar cane in use.-Insect pests and diseases. Facts About Sugar 21(17):394-396, 1926.

\section{Atanasoff, $\mathrm{D}$ [imitr]}

(A study into the literature on stipple-streak and related diseases of potato.) Meded. Landbouwhoogeschool (Wageningen) 26(1): 1-52, 1922.

(Stipple-streak of potato.) Meded. Landbouwhoogeschool (Wageningen) 24(5):1-32, 1922.

Discussion of the importance of the disease, deseribes the symptoms and gives the results of inoculation experiments. 
(Stipple-streak of potato.) Rpt. Int. Conf. Phytopathology and Econ. Entom. 32 p., H. Veeman \& Sons, 1923.

A record of transmission of this disease by inoculation and by aphids.

Methods of studying degeneration diseases of potato. Phytopathology 14(11) : 521-533, 1924.

A discussion of the confusion among workers and suggestions for an improvement of methods.

New studies on stipple-streak disease of potato. Phytopathology $15(3): 170-177,1925$.

A study on masked carriers, of the virus diseases.

(The stipple-streak disease of potato. A complex problem.) Bull. Soc. Bot. Bulgarie 1:43-52, 1926.

The author gives the result of several experiments which show that plants may have virus diseases without showing symptoms. He believes that his work may explain the results obtained by Johrson by inoculating plants with juice from apparently healthy potatoes.

Sprain or internal brown spot of potatoes. Phytopathology 16(10) : 711-722, 1926.

The author gives a discussion of this disease and the results of experimental work which lead to the belief that it is caused by an unknown organism.

Net-necrosis of the potato. Phytopathology 16(12):929-940, 1926.

The author gives a review of the literature, a very complete deseription and the results of experimental work which he summarizes as follows: "Net-necrosis is a tuber symptom, not of leaf roll, but Aucuba mosaic. Spindle sprout, supposed by some to develop on those potato tubers affected with leaf roll and with net-necrosis, has no relation to leaf roll.",

Le "net necrosis" et "stipple streak" sur le pomme de terre. (Net-necrosis and stripple-streak of the potato.) Univ. Sofia Yearbook 1925-26, 4:1-6, 1926.

A preliminary report in which the author states that the net-necrosis of W. A. Orton differs from the necrosis associated with leaf roll. 
Mosaic disease of flower bulb plants. Bull. Soc. Bot. Bulgarie $2: 51-60,1928$.

This paper gives a list of susceptible bulb plants, symptoms and other data.

(Tobaceo diseases.) Sofia Govt. Print. Off. 140 p., 1930.

Brief statement of mosaic disease.

Plum pox: A new virus disease. Univ. Sofia Faculty of Agric. Yearbook 1932-33:11, 1933.

Bitter pit of apples: A virus disease? Yearbook of the University of Sofia, Fact. Agric. 1933-34, 12 : 31-67, 1934.

A very thorough account of the subject and experimental evidence indicating that the diseases is caused by a virus.

(Is bitter pit of apples a virus disease?) Phytopath. Zeitschr. $7(2)$ : 145-168, 1934.

In this article the author gives evidence which tends to show that bitter pit of apples is a virus disease.

Virus diseases of plants: A bibliography Houdojnk Print. Co. Sofia, 219 p. 1934.

A bibliography giving a list of about 3,724 titles of papers in which virus diseases and similar maladies receive attention.

\section{Atwood, G[eorge] G[rey]}

Peach yellow and little peach. New York Dept. Agric. Bull. 61: 1719-1742, 1914.

\section{Auchinleck, C. G., \& Crispeyn, C. P.}

Observations on the occurrence of bunchy top disease of plantains. Ceylon Dept. Agric. Yearbook 1925:33-35, 1926.

A record of treatments given before the eause of this disease was determined.

\section{Aumiot, J[ust]}

Experiences de rejeunissement et de perfectionnement de la pomme de terre. (Experiences on the rejuvenation and improvement of the potato.) Rev. Gén. Bot. 33:183-189, 244 263, 1921. 


\section{Averna-Saccá, Rosario}

Algunas das moestias cryptogamicas do tabaco Nicotiana tabacum. (Some of the eryptogamic diseases of tobaceo $\mathrm{Ni}$ cotiana tabacum.) Bol. de Agric. Sao Paulo, Brasil, 23(7-8) : 201-268, 1922.

Sobre a presença de um protozoario nos tecidos da canna de assucar atacadas pelo "mosaico". (On the presence of a protozoa in tissue of cane attacked by mosaic.) Bol. de Agric. Sao Paulo, Brasil, 27 (8-9) : 183-204, 252-273, 303-319, 388-398, 1926 ; $28: 173-182,1927$.

A histological study in which the author describes a protozoan living in diseased plants. The author believes this organism to be the causal agent.

Badami, B. S. R., \& Iyengar, C. S. R.

The bio-chemistry of the spike disease of sandal (Santalum album Linn.) I. Note on the influence of chlorine on starch accumulation in disease. II. The role of manganese in health and disease. Mysore Sandal Spike Invest. Committee. Bull. 2, 12 p., 1932.

Report of studies on the composition of healthy and spike-diseased sandal (Santalum Album L.) leaves. A low chloride concentration coexist with an excess of starch and a relatively increased diastatic activity in diseased leaves. In regard to manganese the authors declare that spike disease is not due to a lack of it.

\section{Bailey, Irving W[idmer]}

Slime bodies of Robina pseudo-acacia. Phytopathology 13(7): 332-333, 1923.

Micro preparations of the phloem of tissue of Robina pseudo-acacia showed slime bodies described by Strasburger. They are similar to the bodies described by Nelson as associated with mosaic.

\section{Bailey, L[iberty] H[yde]}

Some troubles of winter tomatoes. Cornell Univ. Agric. Expt. Sta. Bull 43 : 149-158, 1892.

A description of winter blight of tomatoes which is now recognized as a virus disease.

Peach yellows. Cornell Univ. Agric. Expt. Sta. Bull. 25, 1890. Bull. 75 : 383-403, 1894.

Gives a description and a discussion. 


\section{Baissac, Louis}

La cane a sucre est encore indemne de mosaïque á Maurice. (Sugar cane still unaffected by mosaic in Mauritius.) Rev. Agric. L'Tle Maurice (43): 7-10, 1929.

\section{Bakke, $\mathbf{A}$ [rthur] L[awrence]}

The comparative rate of desiccation of tubers from normal and diseased potato plants. Phytopathology 9(12) : 541-546, 1919.

This paper is a record of physiological studies which the author summarizes as follows:

(1) Curly-dwarf potato tubers on being desiccated reach equilibrium with evaporating power of the air before normal potatoes of the same variety.

(2) The diseased tubers contain more suberin at the start, but later fissures are developed which cause the curly-dwarf tubers to reach their equilibrium earlier.

(3) Curly-dwarf potatoes which are completely dried, on being placed in water show a greater absorption than desiccated normal tubers similarly placed.

\section{Bald, J[ames] G[rieve,] \& Samuel, G[eoffrey]}

Investigations on the spotted wilt of tomatoes II. Australian Council for Sci. \& Indus. Res. Bull. 54, 24 p., 1931.

$\&$

Some factors affecting the inactivation rate of the virus of tomato spotted wilt. Ann. Appl. Biol. 21(2):179-190, 1934.

The authors state that the inoculum of tomato wilt when stirred in the process of inoculation lost its virulence more rapidly than when left undisturbed and that the rate of inactivation was increased by bubbling air through it. The exclusion of free nitrogen in the bubbling air process practically does not interfere with the rate of inactivation. The authors give the results of six reducing agents tested, (sodium sulphite, sodium nitrite, ferrous sulphate, tannic acid, hydro. quinone acid, eysteine hydrochloride), and discuss them.

\section{Ball, E[lmer] $\mathrm{D}$ [arwin]}

The leafhopper of the sugar-beet and their relation to the curly-leaf conditions. U.S.D.A. Br. Ent. Bull. 66: 32-52, 1910.

The beet leafhopper and the curly-leaf disease that it transmits. Utah Agric. Expt. Sta. Bull. 155, 56 p., 1917.

A review of the literature on the curly-leaf and the beet leaf-hopper. Gives the symptoms and distribution and expresses the opinion that the insects are the cause of the disease.

\section{Barber, C[harles] A[lfred]}

Report on spike disease in Coorg. Indian For. 29:21-31, 1903. 
The mosaic or mottling disease of sugar cane. The main facts of the case to date. Int. Sugar Journ. 23(265) : 12-19, 1921.

A review of the studies on sugar cane mosaic by Johnson, Grey, Edgerton, Earle, Fawcett, Stevenson and Brandes.

On insect transmission of mosaic, especially in Java. Int. Sugar Journ. 25(295) : 346-351, 1923.

Review of Dr. G. Wilbrink's paper in Meded. Proefst. Java Suikerind. 10, 1922.

La situación actual en relación con el matizado en Cuba. (The present position as regards mosaic in Cuba.) Rev. Agric. Puerto Rico 13(4):265-272, 1924. (Int. Sugar Journ. 26 (309) : 469-473, 1924.)

An account of the present status of the literature on the subject with a discussion on the disease.

The influence of mosaic on yield in Louisiana. Int. Sugar Journ. 26(311) : 581-582, 1924.

Review of Brandes's paper in F'acts About Sugar 18(26): 610-61I, 1924.

Experimental Agriculture in Jamaica. The campaign against mosaic. Int. Sugar Journ. 26(309): 474 476, 1924.

Account of the position of sugar cane industry in Jamaica in regard to sugar eane mosaic disease and campaign to eradicate it.

Streak disease of Uba cane in Natal. Int. Sugar Journ. 27 (321) : 472-479, 1925.

Review of Mr. Storey's paper on the subject in Rpt. Proc. Imp. Bot. Congr. p. 132-144, 1924. The author gives a review of our know]edge of this disease, including history, symptoms, range of effects (susceptibility in varieties and wild grasses), and transmission.

The Coimbatore cane seedlings in Bihar. Int. Sugar Journ. 28 (326) : 75-77, 1926.

The Havana Conference on cane diseases. Inter. Sugar Journ. $30(359): 575-582,1928$.

A record of the discussion on diseases of sugar cane. The greater part of the discussion was devoted to mosaic disease of sugar cane. 


\section{Baribeau, [Charles Henri] B[ernard]}

La mosaïque de la pomme de terre. (The mosaic of the potato.) Scie. Agric. 1:181-183, 1921.

\section{Barker, H[enry] D., \& Neal, D. C.}

Plant diseases in Mississippi during 1923. Quart. Bull. State Plant Board Mississippi. 3(1): 13-33, 1924.

Popular notes on sugar cane, potato and sweet potato mosaic.

Plant diseases and pests in Haiti. Int. Rev. Sci. \& Pract. Agric. n. s. 4(1) : 184-187, 1926. (Rev. Appl. Mycol. 5(9): $583,1926$.

\section{Barreto, B[raulio] T.}

Algo sobre la extirpación del matizado. (Facts on mosaic eradication.) Rev. Agric. Com. \& Trab. Cuba 7(4) : 12-13, 1924. (Agricultura 2:8-9, 1924.)

La situación de la enfermedad "Mosaico" en la Provincia de Camagüey. (Mosaic disease situation in the Province of Camagüey.) Agricultura 1:150-152, 1925.)

Barrus, IM[ortimer] $\mathbf{F}$ [ranklin]

Physiological diseases of potatoes. Quebec Soc. Prot. Plants 9th Ann. Rpt. 1916-17: 45-53, 1917.

Potato mosaic and certified seed. Potato Mag. 4:13-14, 1918. Popular.

\section{\& Chupp, Charles D[avid]}

Yellow dwarf of potatoes. Phytopathology 12(3):123-132, 1922. (Abstract.) 12(1) : 39, 1922.

A description of the disease which is new.

$\&$

Potato diseases and their control. New York State Agric, Coll. Ext. Bull. 135, 123 p., 1926.

A popular publication giving good descriptions.

\section{Barss, H[oward] P[hillips]}

International potato disease conference. Potato Mag. 2(2):56, 27-30, 1919.

Brief discussion, chiefly on leaf roll, mosaic and spindling sprout diseases. 
Bean blight and bean mosaic. Oregon Agic. Expt. Sta. Rpt. Dept. Bot. \& Plant Path., Crops Pest \& Hort. Rpt. 3:192196, 1920.

Notes on bean mosaic. Recommendations, for the control of the disease.

Bean mosaic. Oregon Agric. Expt. Sta. Crop Pest \& Hort. Rpt. 3(1915-1920) : 195-196, 1921.

Brief notes on the occurrence of this disease in Oregon. The author states that the disease is produced (mosaic) by the presence of some organism so minute that it eannot be detected by the highest powers of the microscope. Some control measures are given.

\section{Barton-Wright, Eustace, \& IIc Bain, Alan}

Studies in the physiology of the virus diseases of the potato: A comparison of the carbohydrate metabolism of normal with that of leaf roll potatoes. Trans. Roy. Soc. Edin. 57(11): 309-349, 1932.

A very detailed account of the authors' experiments and observation, under control conditions, about the formation of and the nature of translocatory sugars in healthy and leaf roll potatoes. The disease was transmitted by means of Myxus persicae successfully in all cases.

Recent advances in botany. Chapter 9. Virus diseases of plants. Philadelphia 1922. (Phytopathology 22(11):929932, 1932.)

\section{\& Mc Bain, Alan}

Possible chemical nature of tobacco mosaic virus. Nature 132 (3348) : 1003-1004, 1933.

In this short paper the authors report their observations while studying Johnson's No. 1 tobacco mosaic. They describe the several reactions obtained and as conclusions, they found a white crystalline compound containing no nitrogen and yet highly infectious which is considered by the writers to preclude the "living entity" theory of the tobaceo mosaic virus. In its precipitation with safranin it shows affinities with the proteolytic enzymes.

Studies in the physiology of the virus diseases of the potato. II. A comparison of the carbohydrate metabolism of normal with that of erinkle potatoes; together with some observations on carbohydrate metabolism in a "carrier" variety. Ann. Appl. Biol. 20(4):526-548, 1933.

Continuation of previous work. The present investigation was con- 
cerned with the formation of earbohydrates in healthy and crinkle infested potato plants, and the nature of sugar or sugars in transport. A series of observations were also made to determine whether there were any differences in the carbohydrate metabolism when a latent virus (paracrinkle) was present in a variety.

$\&$

Studies in the physiology of the virus diseases of the potato. III. A comparison of the nitrogen metabolism of normal with that of leaf-roll potatoes. Ann. Appl. Biol. 20(4) : 549589, 1933.

Continuation of previous work. The present investigations is concerned with the differences between the nitrogen metabolism of healthy and leaf roll affected potato plants.

\section{Baudys, $\mathbf{E}$ [duard]}

Hospodarska Fytopathologie. Dil 1. Prednasky o chorobach hospodarskych rostlin. (Agricultural phytopathology. Part 1. Lectures on diseases of agricultural plants.) Brno. Rolnicka Tiskarna (Agricultural Press) 327 p., 1929.

Second part on virus diseases.

Fytopathologicke poznamky V. (Phytopathological notes V.) Ochrana Rostlin 9(5-6) : 108-128, 1929. (With German summary.)

Phytopathologické poznamky VII. Ochrana Rostlin 11(6) : 178197, 1931.

Studies on virus diseases of the following crops: soybean, plum, apricot and peach.

\section{Baur, E[rwin]}

Zur Aetiologie der Infektiose Panachierung. (About the etiology of infectious variegation.) Ber. Deutsch. Bot. Ges. 22 (8) : 453-460, 1904.

Ueber die infektiose chlorose der malvaceen. (About the infectious chlorosis of Malvaceae.) Sitzungsb. Klg. Preuss. Akad. d. Wissensch. Bd. 1, p. 11-29, 1906.

The infectious chlorosis of the Abutilon is latent and develops under favorable conditions. Transmitted by grafting.

Weitere Mitteilungen über die infectiöse Chlorose der Malvaceen und über einige analogen Erscheinungen bei Ligustrum und Laburnum. (Further information on infectious chlorosis 
of Malvaceae and on several similar chlorosis appearing on Ligustrum and Laburnum.) Ber. Deutsch. Bot. Ges. 24:416428. 1906 .

Über infectiose Chlorosen bei Ligustrum, Laburnum, Fraxinus, Sorbus, und Ptelea. (About infectious chlorosis on Ligustrum, Laburnum, Fraxinus, Sorbus, Ptelea.) Ber. Deutsch. Bot. Ges. 25 (7) : 410-413, 1907.

The variegations on many plants is due to infections ehlorosis as proved by grafting.

Bemerkungen zur der arbeit: H. Lindermuth, Studien über die sogennannte panaschure und über einige begleitende erscheinungen. (Observations on the work: H. Lindermuth, Studies on the so-called variegations and some accompanying phenomena.) Land. Jahrb. Bd. 37(5):895-897, 1908.

Ueber eine infecktiose Chlorose von Euonymous japonicus. (On an infectious chlorosis on Euonymous japonicus.) Ber. Deutsch. Bot. Ges. 26(18) : 711-713, 1908.

Chlorosis of Euonymous japonicus argenteo-marginatus is not infectious but that of $E$. japonicus aureo-marginatus is infectious.

Das wesen und die Erblichkeits-verhaltnisse der "Varietates albo morginatae hort. von Pelargonium Zonale. (On the nature and hereditary conditions of the horticultural variety albo marginatae of the Pelargonium Zonale. Zeitschr. Ind. Abst. Vererb. 1: 330-351, 1909.

Zur aetiologie der infektiosen panaschierung. (On the etiology of infectious variegations.) Bot. Ges. 22:453-460, 1904.

\section{Bawden, F. C.}

A study on the histological changes resulting from certain virus infections of the potato. Proc. Roy. Soc. London, ser. B. $109: 74-85,1932$.

The author describes three types of necrosis-(1) acronecrosis, (2) acropetal necrosis and (अ) leaf roll necrosis which is Quanjer's phloem neerosis. 
Infra-red photography and plant virus diseases. Nature 132 (3326) : 168, 1933.

The author deseribes the results of his experiments and observations in infra-red photography of virus diseased plants.

Bayon, H. P.

Virus diseases of bacteria, plants and vertebrates. Journ. Trop. Med. \& Hyg. 29(2) : 17-37, 1926.

Beale, Helen Purdy see Purdy, Helen Alice p. 297.

Beaumont, A[lbert,] \& Hodson, W[illiam] E[dgard] H[umphreys]

Sixth Annual Report of the Seale-Hayme Agricultural College,

Newton Abbott, Devon, for the year ending September 30, 1929.

Virus diseases of potatoes are discussed.

\section{Beauverie, J[ean Jules]}

La Maladie de la pomme de terre: "Enroulement et mosaïque."

(The potato disease: Curl and mosaic.) Rev. Gén. Sci. 32 (6) : 175-182, 1921.

Quelques aspects de la dégénérescence des plantes, applications au parasitisme. (Some aspects of plant degeneration, applications to parasitism.) Rev. Gén. Bot. 40:206-225, 264276, 1928.

\section{Beauverie, Marie-Antoinette}

Les maladies a virus d'apres les travaux recents. (Recent work on virus diseases.) Rev. Bot. Appl. \& Agric. Colon. 8(8081) : 1-12, 334-339, (82) : 404-410, 1928.

A review of work.

Les maladies á ultravirus des plantes. (The ultraviruses diseases of plants.) Ann. ser. Bot. \& Agron. Tunisie 9(1-2): $1-173,1932$.

A very comprehensive discussion of the subject subdivided into nine aspects. It is followed by a bibliography of 762 titles.

Bechhold, H., \& Schlesinger, IM.

Grösse von virus der mosaikkrankheit der Tabakpflanze. Phytopath. Zeitschr. 6(6):626-631, 1933.

\section{Beckwith, C[harles] S[teward,] \& Hutton, S[idney] B.}

Cranberry false blossom and the blunt-nosed leafhopper. New Jersey Agric. Expt. Sta. Bull. 491, 16 p., 1929. 
This disease has been known in New Jersey since 1915 and has become abundant since 1920. The authors give a description of the diseased plant, the life history of the insect and methods of control.

Cranberry false blossom. New Jersey Agric. Expt. Sta. Circ. 275, 4 p., 1933.

Popular information about cranberry false blosson in New Jersey, which is becoming a very serious disease in the State. The author formulates, as means of control, the flooding and spraying of the bogs to eliminate the insect carrier, the blunt nosed leafhopper (Euscelis striatulus).

Bedson, S. P., \& Bland, J. 0. W.

A simple method for determining the electrical charge carried by virus particle. Brit. Journ. Expt. Path. 10:67, 1929.

\section{Behrenz, J[ohannes]}

Weitere Beiträge zur Kenntnis der Tabakspflanze. Landwirstch. Versuch. 52:214 432, 1896. (Justs Bot. Jahresb. (Rev.) 28: 1900. Zeitscher. f. Pflanzenkh. 10:192-193, 1900.)

\section{Beijerinck, IM[artinus] W[illem]}

Ueber ein Contagium vivum fluidum als Ursache der Fleckenkrankheit der Tabaksblatter. (About the "Contagium vivum fluidum" as the cause of leaf-spot disease of tobacco leaf.) Verhandel K. Akad. Wetensch. Amsterdam, Sect. 2, deel 6, (5) : 1-22, 1898. (Centr. Bact. II Abt. 5:27-33, 1899.)

Over een contagium vivum fluidum als oorzaak van de Veeckziek te der Tabakblanden. (About the "Contagium vivum fluidum" as the cause of leaf-spot disease of tobacco.) Verlag Koninkl. Akad. van Wetensch. te Amsterdam, Wis. en Natuurk Afd. van Zaterdag 7(6) : 229-235, 1898.

Bernerkung zu dem Anfsatz von Herr Iwanowski Tabaksplanze. Cent. f. Bkt. 25:310-311, 1899.

De l'existence d' un contagieux vivant fluide agent de la Nielle des feulles de Tabac. (About the "Contagium vivum fluidum" as the cause of leaf-spot disease of tobacco.) Achiv. Neerland des Sc. Extractes et Nat. ser. 3:164-186, 1899. 
Uber ein Kontagium vivum fluidum als Ursache Flekenkrankheit der Tabaks-blätter. (About the "Contagium vivum fluidum" as the cause of leaf-spot disease of tobacco.) Centr. Bakt. Abt. II, 27-33, 1899.

\section{Beke, L[adislaus] von}

Beiträge einer Blattrollkrankheit der Kartoffelpflanze. (Contribution to leaf roll disease of the potato.) Jahresb. Ver. Angew. Bot. 10:145-155, 1912.

\section{Bell, A[rthur] F[rank]}

Cane diseases in Louisiana and West Indies. Australian Sugar Journ. 18(10) : 601-607, 1927. (Louisiana Planter (Abstract) $78(8): 147-148,1927$.

Report of the sugar pathologist. Queensland Bur. Sugar Expt. Sta. Ann. Rpt. 28:10-13, 1928.

A brief note on inspection for Fiji and mosaic of sugar cane.

The distribution of sugar cane mosaic. Ref. Book Sugar Industry of the World 7:31-32, 1929.

Report of the results of the observations made by the author during 1924-1928, while visiting the most important sugar cane producing centers. Concludes by inserting a list of the seven major diseases of sugar cane with their geographical distribution.

Work of the Division of Pathology. Queensland Br. Sugar Expt. Sta. Ann. Rpt. $30: 36-41,1930$.

The author states that Fiji disease is prevalent in the Bunderberg area. Gives some Coimbatore canes as susceptible to mosaic.

The Fiji disease menace in Southern Queensland. Queensland Agric. Journ. 38(5) : 417-420, 1932.

A brief history, description of symptoms and method for control.

Dwarf disease of sugar-cane. Queensland Br. Sugar Expt. Sta. Div. Path. Bull. 3: 3-12, 1932. (Farmers' Bull. 8, 8 p., 1933.) A very complete deseription of this new virus disease.

Benecke, F.

Proefhemingen ter bestrijding der "sereh". Semarang. 27 p., 1890. 
Is het mogetijk uit typische "sereh" stekkengezond suikerriet te telen? Meded Proefstat Midden-Java te Semarang $10 \mathrm{p}$. 1890 .

De bestrijding der onder der naam "sereh" saamgevatte ziekteverschijnselen van het Suikerriet. Semarang 16 p. 6 Sept. 1891.

"Sereh". Onderzoekingen en beschouwingen over oorzaken en middelen. Meded. Proefstat. Midden-Java 6: 61-94, 1893.

\section{Bennett, C[arlyle] W[ilson]}

Disease control in black raspberries. Michigan Agric. Expt. Sta. Quart. Bull. 6: 12-14, 1923.

Popular.

Peach yellows and little peach situation in Michigan. Michigan State Hort. Soc. Ann. Rpt. 56:187-196, 1926.

Popular.

Virus diseases of raspberries. Michigan Agric. Expt. Sta. Tech. Bull. 80, 38 p., 1927.

The author discusses the history, economic importance and gives symptoms of the diseases. Also the results of extensive experimental work on dissemination which is by Amphorophora rubi and Aphis rubiphila.

Some raspberry mosaic symptoms. Phytopathology (Abstract) $19(1): 89,1929$.

Further observations and experiments on the curl disease of raspberries. Phytopathology 20(10):787-802, 1930.

From experiments the author concludes that there are two viruses (Alpha and beta) responsible, according to variety, for curl disease of raspberries.

Further observations and experiments with mosaic disease of raspberries, blackberries and dewberries. Michigan Agric. Expt. Sta. Bot. Sect. Tech. Bull. 125, 1932.

Description of the general types of bramble mosaic. Consideration about insect vectors and their behaviour. 
48 THE JOURNAL OF AGRICULTURE OF THE UNIVERSITY OF P. R.

Berg. A. J. J.

Over den invloed eener warmwaterbenbandeling op de kieming van reetstekken. Arch. Suikrind. Nederl. Indië. 34(3) : 82 $89,1926$.

\section{Bergman, H. F., \& Truran, W. E.}

An apparent case of transmission of cranberry false blossom through a natural graft. Phytopathology 23(8):670-672, 1933.

The author describes a case of apparent transmission of cranberry false blossom through a natural graft which up to this date was practicable only with the aid of the leafhopper Ophiola striatula.

\section{Berkeley, G[arven] H[ugh]}

Report of the Dominion Field Laboratory of Plant Pathology, St. Catherine, Ontario. Dept. Agric. Expt. Farms, Div. Ann. Rpt. 1923 : 16-20, 1923.

A report on the virus diseases of raspberries.

\section{\& Jackson, A[ngus] B.}

Raspberry diseases. Phytopathology (Abstract) 14:347, 1924. $\&$

Studies in raspberry diseases, mosaic, leafcurl, rosette and wilt. Canada Dept. Agric. Pamphlet n.s. 72, 15 p., 1926.

Report of the Dominion Field Laboratory of Plant Pathology, St. Catherine, Ontario. Dept. Agric. Expt. Farms, Div. Bot. Ann. Rpt. 1926: 59-102, 124-130, 1927.

Tomato diseases. Canada Dept. Agric. Div. Bot. Bull. 15, 1927.

Studies on tomato streak. Sci. Agric. (Canada) $7(6): 210$ $223,1927$.

Strawberry mosaic. Canada Dom. Bot. Rpt. 1927: 128-130, 1928.

Streak disease of the tomato. Ontario Dept. Agric. Ann. Rpt. Veg. Growers' Assoc. 25: 52-59, 1930.

Diseases of the raspberry. Canada Dept. Agric. Pamphlet n.s. 120, 23 p., 1930. 
A popular discussion (Rev. of Pamphlet N.S. No. 72) summarizing recent information regarding mosaic, leaf curl, rosette or bramble streak in Canada.

Tomato streak: transmission of the disease by seed. Canada Rpt. Dom. Botanist, St. Catherine, Ontario, Ann. Rpt. 1930: 128, 1931.

Suspected strawberry mosaic. Canada Dept. Agric. Div. Bot. Rpt. Dom. Botanist $1930: 125-126,1931$.

This disease has the appearance of being due to virus but there is no absolute proof.

, \& Madden, G. 0.

Transmission of streak and mosaic diseases of tomato through seed. Sci. Agric. (Canada) 13(3):194-197, 1932; 13(7) : 455-457, 1933.

The authors give evidence that these diseases can be transmitted through the seeds. They also demonstrated that the viruses of both diseases existed in the seeds.

Bersch, W[ilhem J. K.]

(The leaf-roll disease of the potato in moor lands.) Zeitsch. Moorkultur u. Torfverwert., 8(2):90-96, 1910.

\section{Besaude, Matilde}

Flagellates in plants. A review of foreign literature. Phytopathology 15(5):273-281, 1925.

This paper does not discuss virus disease, but is of interest because of the protozoan theory of virus diseases.

A degenerescencia das batatas. (The degeneration of potato.) Actualidades Biol. 4: 61 p., 1931.

This is a discussion of the properties of the viruses, cell inclusion, types of virus diseases, classification, losses, resistance and susceptibility and influence of environment.

Betancourt, P. E.

El mosaico en Cuba. (The mosaic in Cuba.) Rev. Agric. Com. \& Trab. Cuba 7:23-25, 1925.

\section{Bewley, W[illiam] F[leming]}

Minute organisms isolated from the virus of mosaic disease of tomato. Nature 112(2825) : 903, 1923.

A preliminary paper giving the results of attempts to grow a virus in culture. Brittle bodies, resembling bacteria were found on the glass above the liquid. 
Mosaic disease of tomato. Cheshut Expt. \& Res. Station Ann. Rpt. 8:42, 1923.

Mosaic disease of cucumber. Expt. \& Res. Sta. Cheshut Herts. 1925 Ann. Rpt. 11: 86-89, 1926.

\section{\& Corbett, W[ilfred]}

Mosaic disease of tomato. Expt. \& Res. Sta. Cheshut Herts. Ann. Rpt. 13:51-59, 1928.

Plant viruses. Nature 126(3178):471, 1930. \& Bolas, Bernard, J.

Aucuba or yellow mosaic of the tomato plant: Reaction of infected juice. Nature 125(3143):130-131, 1930. (Rev. Appl. Mycol. 9(7) : 417, 1930.)

The results of experiments which indicate a destruction of chlorophyl.

\section{, \& Corbett, W[ilfred]}

The control of cucumber and tomato mosaic disease in greenhouses by the use of clean seed. Ann. Appl. Biol. 17(2) : 260-266, 1930.

Mosaic disease of cucumber and tomato is decidedly transmissible. Roguing of diseased plants is a way to clean seed. The use of clean seed reduced the infection.

The nature of the virus principle in mosaic disease. Nature $127(3203)$ : 442, 1931.

Details of observations made by the author is given.

The nature of the virus principle in mosaic disease. Expt. \& Res. Sta. Cheshut Herts. 17: 45-46, 1932.

The author prepared juices from mosaic and healthy plants which were infected with culture of bacterial organism isolated from diseased stems. The infected juice became almost elear in 24 hours, which suggested bacteriophage type. No change occurred when aucuba mild mosaic and striped disease were used.

\section{Bijl, P. A. van der}

Agriculture in the winter rainfall area. The work of an important institution. (Ex Annual Rpt. Sec. of Agri. Year ending June 30, 1931). Farming in South Africa, 6:354358, 1931. 
Reports a virus disease on Raphanus raphanistrum, Calendula officinalis, Tithonia diversifolia and Passiflora sp.

\section{Bijlert, A[lbertus] van}

Opmerking, omtrent de verbreiding van een viekziekte, Meded.

Slands Plantutuin. 43:49-52, 1899.

Observations about the spread of the diseases on the field.

\section{Binkley, A[lmond] $\mathbf{I}$.}

Transmission studies with the new psyllid-yellows disease of

Solanaceous plants. Science n.s. $70(1825): 615,1929$. (Rev. Appl. Mycol. 9(5) : 332, 1930.)

Transmission of the disease by means of Paratriozoa cockerelli indicates that this disease is caused by a virus.

Transmission studies with the new psyllid-yellows disease of

Solanaceous plants (a preliminary report). Proc. Amer. Hort. Sci. 1929 : 248-254, 1930.

The 1928 tomato variety work at the Agricultural Experiment Station was a complete failure because of this disease which is carried by Paratriozoa cockerelli. This insect also transmits the disease to Capsicum annurm, Solanum Pseudocapsicum and eggplant.

\section{Biourge, [le Chanoine] $\mathrm{P}$ [h.]}

La vaie cause de la degénérescence de la pomme de terre non pas Virus filtrant mais microbe (Bac. ruber N. et L.) (The true cause of the degeneracy of the potato is not a filterable virus but a microbe (Bac. ruber N. et L.) Agric., Louvain, 7 p., 1930.

Nouvelles recherches sur les maladies de la pomme de terre dites á virus filtrants. (New investigation on the diseases of potatoes due to filterable viruses.) Agricultura 32(2) : 77114, 1932.

\section{Birkeland, J[orgen] M.}

Electrophoretic studies on purified plant viruses. Phytopathology (Abstract) 23(1):4-5, 1933.

Experiments in acquired immunity in tobaceo mosaic and spot necrosis. Phytopathology (Abstract) 23(1):5, 1933. 
Serological studies of plant viruses. Bot. Gaz., 95(3):419 436, 1934.

The author states:

1. That in addition to the antigenic constituents of healthy plants an antigenic element was found accompanying and inseparable of the virus itself. Antibodies accompanying one virus is specific to it.

2. That viruses may be freed from the antigenic constituents of healthy plants, but not from the specific antigenic factors accompanying.

3. That close association of the antigenic factor with infectivity and the specific nature of the antigenic fractions the different viruses strongly suggest that this specific antigenic factor is either the virus itself or a virus-plant-protection complex in which the virus plays the role of haptene. Precipiting test should prove to be a valuable aid in the further classification of plant viruses.

\section{Birmingham, W. A.}

Conditions resembling American peach rosette. Agric. Gaz. N.

S. Wales $31: 581-582,1920$.

Description and suggestions for control.

\section{Bisby, G[uy] R[ichard], \& Olaas, G.}

Potato diseases in Minnesota. Minnesota Agric. Expt. Stat. Bull. 190, 44 p., 1920.

Includes brief popular notes on several virus diseases of the potato.

\section{Blackman, V[ernon] H[erbert]}

Discussion on some similarities and dissimilarities between plant and animal diseases, with special reference to immunity and virus diseases. Brit. Med. Journ. 1922 (3225) : 718-722, 1922.

\section{Blake, Maurice A[din]}

Peach yellow and little peach. New Jersey Agric. Expt. Sta. Bull. 226, 26 p., 1910.

Extensive discussion of the symptoms of these two diseases and also a discussion of winter injury.

\section{\& Connors, C[harles] $\mathrm{H}$ [enry]}

Peach yellow and little peach at Vineland. New Jersey Agric. Expt. Sta. Rpt. 1916: 72-74, 1917.

\section{A[lois]}

\section{Cook, Melville T[hurston,] \& Schwarze, C[arl]}

Studies on peach yellow and little peach. Phytopathology (Abstract) $7(1): 76-77,1917$. 


\section{\& Connors, C[harles] H[enry]}

Recent studies on peach yellows and little peach. New Jersey Agric. Expt. Sta. Bull. 356, 62 p., 1921. (Phytopathology (Abstract) $11: 140-142,1921$.)

Records of very thorough field studies of these diseases.

Prominent enemies of the peach. Amer. Fruit Growers 43(2): 8, 21, 31-33, 1923.

Blakeslee, A[lbert] F[rancis], \& Avery, B. T.

Mutations in the Jimson weeds. Journ. Heredity 10:111-120, 1919.

A graft-infectious disease of Datura resembling a vegetative mutation. Journ. of Genetics 11(1) : 17-36, 1921.

An apparent case of non-Mendelian inheritance in Datura due to a disease. Proc. Nat. Acad. Sci. $7: 116-118,1921$.

\section{Blanchard, E[mile] \& Perret, Claude}

La enroulement de pomme de terre. (Leaf roll of potato.) Compt. Ren. Acad. Agric. France 3(31) : 894-895, 1917.

La maladie de l'enroulement des pommes de terre. (Leaf-roll disease of potatoes.) France Ann. Serv. Epiphy. 6:320-326, 1918.

Recherches relatives a la maladie de l'enroulement de la pomme de terre affectuées dans le departement de la Loire. (Experiments on leaf roll disease of potatoes in the Department. of Loire.) France Ann. Sèrv. Epiphy. 5:242-252, 1918.

The authors reported in the article the susceptibilty of differen varieties and stated the date of appearance of the disease in 1918 Informed also that the use of stable manure and nitrate of soda reduced the losses due to the disease. The causal agent is not found in the soil, nor in the surface of the tuber.

\&

Sur l'enroulement des feuilles de la pomme de terre. (Leaf roll of potatoes.) Compt. Rend. Acad. Agric. France 5(10): 356-358, 1919.

After several years of experiments the authors believe that nitrogen hunger is the chief symptom of the disease. Is considered a degenerative disease due to intensive asexual propagation. Good fertilizing may improve the growth. 
\&

La maladie de l'enroulement de la pomme de terre (Leaf roll disease of potato.) France Ann. Serv. Epiphy. 7:294-303, 1921.

The authors disagree with Quanjer and others. They believe the disease to be physiological.

\section{Blaringhem, L[ous Florimond]}

Mosaïque hereditaire chez le pois Pisum sativum. (Hereditary mosaic in peas Pisum sativus.) Compt. Rend. Acad. Sci. (Paris) 175(26) : 1432-1434, 1922.

\section{Blattny, C[tibor Eugen Marie Karel]}

Studie o mosaikovych chorobach rostlin kulturnich, hlavne Bramboru. (Studies of diseases of cultivated plants, chiefly of the potato, related to mosaic.) Zemedelisky Archir. 15(910) : 459-482, 1924. (With French summary 16(1-2):8.)

Account of mosaie of Clerodendon fragrans.

(Uncommon diseases and pests of potatoes in 1925 ) Ochrana Rostlin 5: 74-76, 1925.

(Preliminary report of the irradiation of potatoes affected with leaf roll with $B$ and radium rays.) Ochrana Rostlin, Prag 6(3) : 48-53, 1926.

(Virus diseases of raspberries and blackberries.) Ochrana Rostlin, Prag. 7(3-4) : 62-70, 1927.

(International experiments in Holland and Czecho-Slovakia on the degeneration of potato seed in different regions due to virus diseases.) Zemedesky Archiv., Prag 19:327-330, 423$438,1928$.

O methodáck studies virusovych chorob u chmele. (Methods of studying the transmission of Hop virus diseases.) Ochrana Rostlin 8(2-3): 51-56, 1928.

(The mosaic of the lily of the valley (Convallaria majalis L.) Ochrana Rostlin Prag 9(1): 19-21, 1929. 
Poznamky o virovych a pribuzuych choroback rostlin I. (Notes on virus and similar diseases of plants I.) Ochrana Rostlin 10(4-5) : 130-138, 1930. (With German summary.)

Several virus diseases are briefly discussed.

Studio o kaderavosti Chmele. (Studies on the "Kaderavost" disease of Hop.) Recueil de Trav. des Inst. des Recherches Agron. de la Rep. Tehecoslovaque Prag. 46, 44 p, 1930. (With German and French summaries.)

An extensive discussion about "Kaderavost" disease of hop being in Czecho-Slovakia for 45 years. It is regarded as a virus disease.

Pokus S pasazi vira brambose. (Experiment on the passage of potato virus.) Ochrana Rostlin 10(3):65-70, 1930.

The virus can be transmitted from the tuber of a potato so resistant that it does not show symptoms to a susceptible variety that does show symptoms.

Virové choroby. (Virus diseases.) Ochrana Rostlin 11(3-4): 138, 1931.

A report on the condition for the year.

Lze Zjistiti pritomost vira pusobiciho nekteré choroby Bramboru $\mathrm{v}$ jéjich prenasesi, msicich? (Can the viruses that cause certain potato diseases be detected in their aphid vectors?) Vestn. Kral. Ces. Spol. Nank. 7 p., 1931.

Only one difference between vectors from diseased and healthy plants was observed. In the majority of the former the aureola around the cell nucleus was dark, in the latter it was clear.

\section{\& Vukulov, V.}

Mosaic bei Epiphyllum truncatum. (Mosaic on Epiphyllum truncatum.) Gartenbauwissenchaft 6:425-432, 1932. (Zeitschr. Pflanzenkrank. (Abstract.) 43(2): 88-59, 1933.)

Description of a virus disease on the eactus Epiphyllum truncatum.

\section{Blodgett, F[orest] IM[ilo,] \& Fernow, Karl [Hermann]}

Testing seed potatoes for mosaic and leaf-roll. Phytopathology (Abstract) 11(1) : 58-59, 1921.

The relation of time and temperature to the killing of potatoes and potato mosaic virus. Phytopathology (Abstract) 12(1): 40-41, 1922. 


\section{Fernow, Karl [Hermann,] \& Perry, F[rank] R [ichard]}

Testing seed potatoes for mosaic and leaf-roll. Phytopathology (Abstract) 12(1) : 40-41, 1922.

Time-temperature curves for killing potato tubers by heat treatments. Phytopathology 13(11) : 465-475, 1923.

The experiments reported in this work were conducted with particular reference to mosaic and leaf-roll diseases.

Hot water and hot air treatments of potatoes. Phytopathology (Abstract) 13(1) : 55, 1923.

Tobaceo mosaic on potatoes. Phytopathology 17(10): 727-735, 1927.

The author gives the results of eross inoculation experiments. The results agree with those obtained by Johnson and Fernow.

A potato virus on peppers. Phytopathology 17(11): 775-782, 1927.

The author gives the results of inoculating peppers with potato virus. The resulting diseases appears to be the same as mosaic virus from potatoes used by Fernow on Nicandra Physalodes and Nicotiana glutinosa.

Blood, H[erbert] L[oran]

A "streak" of tomatoes produced by a disturbing principle from apparently healthy potatoes in combination with tomato mosaic virus. Phytopathology 18(3):311-312, 1928.

Richards, B[ert] L[orin], \& Wann, F[rank] B[urkett]

Studies of psyllid yellows of tomatoes. Phytopathology (Abstract) 23(11): 930, 1933.

\section{Boas, Friedrich}

Die zuchterische Bekampfung der Blattrollkrankheit der Kartoffel. (Control through breeding of the leaf-roll disease of potatoes. Illustr. Landw. Zeitg. $37: 341-342,1917$. (Zeitschr. Pflanzenkrank. 29 : 54, 1919.)

The author makes distinctions between hereditary and non hereditary leaf-roll. The latter is due to Fusarium.

Beiträge zur Kenntnis des Kartoffelabbauses. (Contribution to the knowledge of deterioration in potatoes.) Ztschr. Pflanzenkrank. 29(5-6):171-176, 1919.

The author states that very insignificant difference in hydrogen-ion 
concentration may have marked effect on metabolism. He found in his experiments that without exception the cell sap of sound plants showed appreciably more acidity than diseased plants in regard to catalase, his experiments gave obvious differences.

Bohm, F.

Die züchterische Bekämpfung der Blattroll krankheit. (The breeding against leaf roll disease.) Ill. Landw. Zeitung. No. $52,1917$.

\section{Bohme, R. W.}

Einige Fälle spontaner Infektion mit echtem tabak-Ring flecken-Virus. (Some cases of spontaneous infection with the true tobacco ring spot virus.) Phytopath. Zeitschr. 6(5) : 507-515, 1933.

Report of observations of development of a virus apparently identical to ring spot on tobacco. Information in regard to mechanical transmission, no insect transmission of this disease has apparently been recorded.

Vergleichende Unterasuchungen mit Stämmen des " $X$ " und " $Y$ " virus. (Comparative studies on strains of the " $\mathrm{X}$ " and "Y" viruses.) Phytopath. Zeitschr. 6(5):517-534, 1933.

In his experimental work the author differentiated four " $X$ " vi. ruses on potatoes and three distinct forms of the " $Y$ " virus on the basis of their effects on various hosts of which Nicotiana sylvestris and Solanum aculeatissimum showed the most characteristic symptoms. Other very valuable data is included as to transmission experiments.

\section{Bohutinsky, G[ustav]}

Beiträge zur Erforschung der Blattrollkrankheit. (Contribution to the investigations on leaf-roll disease.) Monastchefte fur Land-Wirtschaft. Jahrg. 2(4) : 118-130, 1909. (Zeitschr. fur das Land-Wirtschaft. Versuchswesen in Oesterreich, Jahrg. 13(7): 607-633, 1910.)

\section{Bolas, Bemard D., \& Bewley, W[illiam] F[leming]}

Aucuba or yellow mosaic of the tomato. II note on the metabolism. Nature 126(3178): 471, 1931.

The authors suggest that the virus acts on the starch to form (1) nitrogen and protein, (2) attacks the chlorophyll and causes a mottling and (3) reacts on the respiration of the plant. 
Physiological investigations of mosaic disease in the garden tomato. Expt. \& Res. Sta. Cheshut Herts. 16: 62-67, 1930.

A study of the influence of temperature and light. The period of incubation varies with the mottle type by temperature and light. The most pronounced mosaic was with blue-green light.

Physiological investigations of mosaic disease. Expt. \& Res. Sta. Cheshut Herts. 17 : 47, 1932.

The virus in the living tissue can be destroyed by the passage of a direct electric eurrent of 5.0 mieroamps. per sq. em. of tissue.

\section{Bonazzi, Augusto}

Study on sugar cane mosaic. Science n.s. 64(1665) : 529-530, 1926. (Rev. Appl. Mycol. 6(3): 184-185, 1927.)

The author describes a method of inoculating sugar cane by drilling a hole into healthy cane and inserting a plug of corresponding size cut from a mosaic cane.

\section{Boncquet, P[ierre] A[uguste] \& Hartung, W[illiam] J[ohn]}

The comparative effect upon sugar beet of Eutettix tenella

Baker from wild plants and from curly top beets. Phytopathology 5(6): 348-349, 1915.

This is a brief note giving the results of experiments. Insects from curly top beets carried the disease to healthy beets. Insects from wild uninfected plants did not produce the disease until after having fed on diseased beets.

Presence of nitrates and ammonia in diseased plants. Its significance with regard to crop rotation and soil depletion. Journ. Amer. Chem. Soc. 38(11) : 2572-2576, 1916.

Wild vegetation as a source of curly-top infection of sugar beet. Journ. Econ. Ent. 10(4) : 392-397, 1917.

Bacillus morulans n. sp. A bacterial organism found associated with curly top of the sugar beet. Phytopathology 7:269. 289, 1917.

No proof that this organism is the eause of the disease. This paper gives the results of extensive studies on an organism found in sugar beets.

Discovery of curly leaf of sugar beet in the Argentine Republic. Phytopathology 13(10): 458-460, 1923.

Also reported the finding of Entettix tenella. 
Bonde, R.

The spread of spindle tuber by the knife. Amer. Pot. Journ. 4: 51-52, 1927.

Popular.

\section{Böning, $\mathbf{K}[\operatorname{arl}]$}

Die Mosaikkrankheit der Rübe. (Mosaic disease of beet.) Forchungen usw. Heft 3:81-128, 1926. (Ztschr. Pflanzenkrank. Bd. $37: 19-15,1927$.

Uber die Wechselseitige Uebertragbarkeit der Mosaikkrankheiten von Rübe und Spinat. (Reciprocal transmission of beet and spinach mosaic.) Centr. Bakt. II Abt. 71:490497, 1927.

Spinach mosaic was transferred to beets by Aphis fabae and Mitcrosiphum sp. Spinach mosaic was transferred to spinach by inoculation but beet mosaic could not be transferred in this manner.

Die Kalifornische Blattrollkrankheit der Rübe. (California leaf-roll disease of sugar beet.) Centr. Bkt. II Abt. 72(1524) : 379-398, 1927.

A review of the literature on curly top and mosaic of the sugar beet.

Die Mosaikkrankheit der Ackerbohne Vicia faba L.) (The mosaic disease of broad beans (Vicia faba L.) Forsch. Gebtet. Pflanzen. Kr. 4:43-111, 1927.

\section{\& Schaffnit, [Johannes Martin] E[rnst Christian Otto]}

Die Mosaikkrankheit der Rübe. (The mosaic disease of beet.) Zeitschr. des Vereins der Dent. Zuck-Indust. Bd. 77, 1927. (Technisches Teil. Heft 844:13-72, 1927. Forsch. Geb. Pflanzenkrank. 3: 8-128, 1927. Zeitschr. Pflanzenk, 37(1-2): 19-35, 1927.)

Panaschierung und Mosaikkrankheit. (Variegation and mosaic disease.) Gebt. Pflanzen. u. d. Immu. in Pflanzenrich Heft. $4: 16-22,1927$.

Uber den gegenwärtigen Stand einiger die Erforschung der Viruskrankheiten betreffenden Fragen. Prakt. Blätt Pflanzenb. u Schutz. 5: 33-42, 1927. 
Die Mosaikkrankheit des Tabaks. An die: Bericht über des Auftreten von Krankheiten und Schädlingen am Tabak im Jahre 1927. (The mosaic disease of tobacco. In his Report on the diseases and pests occurring during the year 1927.) Arb. aus der Bayer. Lands. Pflanzenb. Pflanzen sch. Heft 4: 36-40, 1928.

Account of the occurrence of the disease, discussion and comparative data of other workers on the subject.

Ist die durch die Blattwanze (Piesma quadrata Fieb.) hervorgerufene Erkrankung des Rübe eine Viruskrankheit? Anzeigq. Schädlingskunde 4:8-10, 1928.

Beobachtungen aus der Praxis über die wechselnde Aüspragung der Merkmale der Mosaikkrankheit der Kartoffel im Verlaufe der vegetationsziet. (Field observations on the variations of the symptoms of potato mosaic disease during the growing season.) Blätter Pflanzenb. n. Pflanzenschutz 5(12):308$315,1928$.

A study of the masking of symptoms with reference to its bearing on inspection.

Beiträge zum Studium der Infektionsvorgänge pflanzenzlicher Viruskrankheit. I. Mitteilung. (Contribution to the study of the infection processes of the virus diseases of plants. Part I.) Zeitschr. fur Prasitenkunde 1(1):198-230, 1928. (Rev. Appl. Mycol. $7: 659-660$, 1928.)

The author discusses the rate of spread of the virus and the resuits of double inoculations.

Insecten als Ueberträger von Pflanzenkrankheiten. (Insects as carriers of plant diseases.) Zeitschr. Angew. Ent. 15(1) : 1929.

Krankheiten, Schädlige und Witterungssehaden am Tabak im Jahre 1929. Prakt. Blatt. Pflanzend. u. Schuts. 8:27-33, 1930 .

Deformationskrankheit an Rübe und Spinat. (Deformation disease on beet and spinach.) Zeitschr. Pflanzenk., Pflanzenpath. u Pflanzenschut. 40(7) : 315-323, 1930. 
A description of a leaf deforming diseases of beets and spinach, Rumex obtusifolius and $R$. crispus. It is transmitted by Aphis rumicis and Myzus persicae.

Zur Atiologie der streifen-und Krauselkrankheit des Tabaks. (On the etiology of the stripe and curl disease of tobacco.) Zeitschr. fur Parasitenkunde 3(2): 103-141, 1931.

Description of the disease with full account of these studies. Believes that these diseases are carried in the soil. No evidence of seed transmission. Inoculated both diseases into Nicotiana tabacum N. macrophylla and $N$. rustica.

Booberg, K. G.

De bergbibitaanplant op Java. (The cultivation of mountain sets in Java.) Arch. voor Java Suikerindustrie. Deel II 40 (37) : 761-767, 1932.

The sereh disease is of no importance owing to the use of resistant varietes. The hill nurseries are decreasing.

Borg, P[aul]

Appendix F. Report of the Plant Pathologist. Reports on the working of (Multa) Govt. Depts. during the financial year 1927-28, p. T15-T16, 1929. (Rev. Appl. Mycol. 9(3):158, 1930.)

Borisevich, G. F.

(The mosaic of the leaves of the sugar beet.) In V. P. Muraviov. Mozaichnye Bolezni Sakharnoi Svekly (Mosaic diseases of sugar beet.) Kiev, SS. U. Soiuzsakhara p. 141-160, 1930. (English Abstract p. 158-160.)

Sugar-beet leaf mosaic is very common in Ukrania ranging from 15 to 100 per cent on mother beets and from 0.5 to 100 per cent on first year beets. The author also discusses carriers, wild hosts, sugar content, deterioration and insect control.

Bouriquet, A. G.

La rosette de l'arachide á Madagascar. (Peanut rosette disease in Madagascar.) Agron. Colon. 20(160) : 105-108, 1931.

A disease which appears to be the same as the one reported from Africa.

Les maladies du Manioc á Madagascar. (Cassava disease in Madagascar.) Rev. Path. Veg. \& Ent. Agric. 19(8-9-10): 290-297, 1932.

Brief morphological and economic account of the chief diseases in Madagascar, among which mosaic disease of cassava is discussed, giving control methods. 


\section{Bouygues, $\mathrm{H}[\mathrm{enri}]$}

Sur la Nielle des feuilles du Tabac. (La "Nielle" of tobacco

leaf.) Compt. Rend. $137: 1303-1305,1903$.

\section{\& Perreau}

Contributions a l'étude de la nielle des feuilles de Tabac. (Contribution to the study of "La Nielle" of the tobacco leaves.) Compt. Rend. 139 : 309, 1904.

\section{Bovell, J [ohn] R[edman]}

Sugar cane mosaic. Barbados Dept. Agric. Ann. Rpt. 19211922 : 19, 1922.

\section{Boycott, A. G.}

The transmission from life to death: The nature of filterable viruses. Smithson. Inst. Ann. Rpt. 1929 : 323-343, 1929. Proc. Roy. Soc. Med. Path. Sect. 22(1) : 55-69, 1929. Nature 123: 91-98, 1929.) (Proc. Roy. Soc. Med. London 22(1) : 55-69, 1929.)

\section{Bradford, F. C., \& Joley, Lloyd}

Infectious variegation in the apple. Journ. Agric. Res. 46(10): 901-908, 1933.

The authors refer to a paper reporting infectious variegation of apple published in France before 1835. They report the occasional occurrence of the disease in United States. Description of the behaviour of the disease.

\section{Brandenbourg, E[rnst]}

Die Mosaikkrankheit (Gelbfleckigkeit) des Spinats und ihre Ubertragung durch Insecten. (The mosaic disease (Yellow spot disease) of spinach and its transmission by insects.) Zeitschr. Pflanzenkrank u. Schutz. 37(5-6): 173-182, 1927.

Ueber Mosaikkrankheiten an Compositen. (Mosaic disease of Compositae.) Forsch. Gebiet Pflanzenkr. 5:39-72, 1929.

A discussion of a mosaic of Lactuca sativa var capitata and Dahtia variabilis and of mottling of some other members of this family.

\section{Brandes, E[lmer] W[alker]}

The mosaic disease of sugar eane and other grasses. U.S.D.A. Bull. 829, 26 p., $1919 . \quad$ (Minist. Agric. Indus. Com. ser. Inf. Rio de Janeiro 33 p., 1926.)

Gives a history of the disease, distribution and losses in the United States, symptoms, varietal susceptibility, other hosts, nature of the disease methods of transmission and methods of control. 
Artificial and insect transmission of sugar-cane mosaic. Journ. Agric. Res. 19(3) : 131-138, 1920.

Gives the results of series of experiments demonstrating that sugar cane mosaic is transmitted by Aphis maidis.

Mosaic disease of corn. Journ. Agric. Res. 19(10) :517-522, 1920.

Gives the symptoms and distribution of the disease. Also experiments showing that Aphis maidis is a carrier.

Mechanics of inoculation with sugar-cane mosaic by insect vectors. Journ. Agric. Res. 23(4) : 279-283, 1923.

Gives a review of the literature and deseribes the mechanics of inoculations.

\section{\& Klaphaak, Peter J[ohn]}

Cultivated and wild hosts of sugar cane or grass mosaic. Journ. Agric. Res. 24(3) : 247-262, 1923. (Rev. Appl. Mycol. 2: 584 585, 1923. Rev. Appl. Ent. ser. A 11:449, 1923.)

Gives the result of testing 40 species of grasses to determine their susceptibility to mosaic. Makes statement that thirteen species of grasses are susceptible to the virus of sugar-cane mosaic. Give the results of inoculation experiments.

Growth stimulation and pest and disease control by hot-water treatment of sugar-cane seed. Louisiana Planter 71(19): 371-372, (20)392-394, (21)412, 1923. (Rev. Appl. Mycol. 3 : 301-302, 1924.)

Hot water treatment had no effect on sugar-cane mosaic. \&

Breeding of diseases resistant sugar plants for America. Ref. Book Sugar Indus. of the World, July 1923.

Mosaic's role in limiting Louisiana yields. (El rol de la enfermedad del mosaico en limitar los rendimientos de Luisiana.) Rev. Indus. Agric. de Tucumán 15(1-2) : 29-33, 1924. (Facts About Sugar 18(26):610-611, 1924, Int. Sugar Journ. 26 (311) : 581-582, 1924.)

Mosaic is one of the many factors causing low yields. This is a popular paper containing much valuable data.

Kavangerie sugar cane in Puerto Rico. Facts About Sugar 21 (18) : 422-424, 1926. 
Potash not a Panacea. Facts About Sugar 25(19) : 472, 1930.

Controversial. Reply to Mr. Otto Hasch in regard to the use of potash to cure sugar eane mosaic disease.

Breeding for resistance to mosaic. Facts About Sugar 26(11): 490-493, 1931.

Reports that Saccharum robustum from Papua appears to be free from mosaic. The disease was found in Papua on several varieties of S. officinarum and on Coix lachryma-jobi. The author also reports it on a number of hybrid varieties.

\section{Breda de Haan, J[acob] von}

Eene nieuwe suikerriet ziekt in W. Indie. (A new sugàr cane disease in the West Indies.) Teysmania 4:544-548, 1893.

De gele strepenziekte bij suikerriet. (Yellow stripe disease on sugar cane.) Teysmania 4:511-522, 1893.

Vooloopige mededeeling over het Peh Sem der Mosaiickziekte bij de Deli-Tabak. Teysmania p. 567-584, 1899.

\section{Breemen, P[ieter] J[ohan] von}

Eenige Waarnemingen Omtrent het zwermen van Aphis maidis Fitch. (Some observations concerning the imigrations of Aphis maidis Fitch.) Arch. Meded. Java Suikerind. 18:513543, 1926. (Facts About Sugar 21(39): 919, 1926.)

Gives the results of traping the insect which indicates that they have definite periods for migration. The sudden outbreaks of the disease are correlated with the periods. Agrees with J. Alfaro from Cuba.

Strepenziekte en bladluizen. (Stripe disease and leaf lice.) Arch. Java Suikerind. 1926: 910-912, 1926.

Aphis maidis op suikerriet bij Pasoervean. (Aphis maidis on sugar cane at Pasoervean.) Arch. Java Suikerindus. 35(3): 557-577, 1927.

This paper reports a continuation of the author's studies on the swarming of Aphis maidis. The author recommends the roguing of the field in advance of the swarming so as to remove the centers of infection. 
Verdere-waarnemingen omtrent het zwermen van Aphis maidis Fitch. (Further observations on the migrations of Aphis maidis Fitch.) Arch. Meded. Java 35:583-588, 1927.

Proven over strepenziekte met Klaboes in het vije veld. (Yield despite stripe disease in five fields at Klaboes.) Arch. Java Suikerindus. 13 : 579-582, 1927.

\section{Brehmer, G[ustav] von}

Die anatomische und mikrochemischen veränderungen der Kartoffelleptoms. (The anatomical and microchemical changes in the leptome of the potato.) Rept. Inter. Conf. Phytopath. \& Econ. Ent. Holland 1923 : 79-85, 1923.

The author discusses necrosis, obliteration, and necrobiosis. Necrobiosis is an old age character of both normal and diseased plants. Necrosis is a character of leafroll plants. Obliteration is a character of plants that are dying after maturity.

Der Einfluss der Kalidüngung auf die Blattrollkrankheit der Kartoffell. (The influence of potash fertilization on the leaf roll disease of potato.) Ernährung d. Pflanze 20:12, 1924.

Een cytologisch onderzoek van Strepenziekte bij Zuikerriet en andere planten. (A cytological study of stripe disease of sugar cane and other plants.) Meded. Proefst. Java Suikerindus. 11:337-371, 1926. (Rev. Appl. Mycol. 5(12): 765-766, 1926.)

The author reports the finding of intracellular bodies in mosaic disease of sugar cane and gives a general discussion of the subject.

\section{\& Barner, J.}

Uber die Viruskrankheiten der Kartoffel. (On the virus diseases of the potato.) Biol. Reichst. f. Land-und Forst. 18(1): 1-56, 1930.

Biologische Bekampfungsmethoder der Viruskrankheiten. (Biological methods to combat virus diseases.) Forstschitte der Medizin 49(8). 1931.

Uber die Viruskrankheiten verschiedner Kulturpflanze. (On virus diseases of different cultivated plants.) Second Int. Congr. Comp. Path. (Paris) p. 365, 1931. 
Vergleichende Pathologie und Biologische Bekämpfungsmethoden der Viruskrankheiten im allgmeinen. (Comparative biological and pathological methods to combat virus diseases in general.) Second Int. Congr. Comp. Path. (Paris) 2 : 358 362,1931 .

\section{\& Rochlin, Emilia}

Histologische und mikrocheminsche Untersuchungen über pathologische Gewebeveränderungen viruskranker Kartoffelstanden. (Histological and microchemical investigations on the pathological changes of the tissues of virus-diseased potato plants.) Phytopath. Zeitschr. 3(5): 471-498, 1931.

The authors give evidence that nutritional disturbances give symptoms similar to those resulting from virus diseases.

Les maladies á virus de diverses plantes cultivées. (Virus diseases of different cultivated plants.) Deuxiémé Congr. Inter. Path. Comp. (Paris) 1:355, 1931.

\section{Brewer, P[earl] H[arvey,] Kendrick, J[ames] B[lair,] \& Gardner;} IIax W[illiam]

Effect of mosaic on carbohydrate and nitrogen content of the tomato plant. Phytopathology 16(11) : 843-851, 1926.

Chemical studies which show that soil conditions did not materially affect the two diseases. In most cases there was a reduction of total weight and in all eases a reduction of carbohydrates as a result of mosaic. No reduction in nitrogen content.

\section{Kraybill, H[arry] R[eist,] \&}

Purification of the virus of tomato mosaic. Phytopathology 17 (10) : 744, 1927.

A description of two methods which the authors believe to be an improvement over past methods.

\section{\&}

Purification and certain properties of the tomato mosaic virus. Phytopathology (Abstract) 19(1): 108, 1929.

\section{Max W[illiam]}

Samson, R[ayburn] W[alter,] \& Gardner;

Purification and certain properties of the virus of typical tomato mosaic. Phytopathology $20(12): 943-950,1930$.

This paper is a continuation of previous work, effect of different filters, temperature and $\mathrm{pH}$ concentration on the virus is discussed. 


\section{Brick}

Neues über die Blattrollkrankheit der Kartoffel. (News about the leaf-roll disease of the potato.) Krög. Ratgeb. Obst-u Gartenb. 4, No. 4, 1924.

\section{Brierley, Philip}

Studies on mosaic and related diseases of dahlias. Contr. Boyce Thompson Inst. 5(2) : 235-288, 1933.

Extensive and careful experimental work performed in partial fulfilment of the requirements for the degree of Doctor of Philosolophy in the Graduate School of Cornell University.

Virus diseases of Dahlia. Phytopathology (Abstract) 23(1):6, 1933.

Different types of the disease are discussed as well as its insect vector (Myzus persicae) and other ways of transmission.

Dahlia mosaic and its relation to stunt. Bull. Amer. Dahlia Soc. 9(65) : 6-11, 19, 1933.

Cross-inoculation on virus diseases of dahlia, which the author states is not synonymous with "stunt". Notes on the transmissibility and control of the disease.

\section{\& Mc Whorter, Frank P.}

A mosaic disease of bulbous iris. Phytopathology (Abstract) 24(1) : 4, 1934.

\section{Brierley, W[illiam] B[roadhurst]}

On a case of recovery from mosaic disease of tomato. Ann. Appl. Biol. 2(4) : 263-266, 1916.

Economic importance of virus diseases of plants. Brit. Soc. Adv. Sci. Rpt. (Abstract) 91: 493, 1923.

\section{Brittlebank, C[harles] C.}

Tomato diseases. Victoria Dept. Agric. Journ. 17:231-235, $498-500,1919 ; 18: 413-416,1920$.

A description of the spotted wilt of tomato.

\section{Britton-Jones, H. R.}

Stripe disease of corn (Zea mays L.) in Trinidad. Trop. Agric. (Trinidad) 10(5) : 119-122, 1933.

The author observed since 1929 a stripe disease of corn which occurred in Trinidad and elosely resembling that deseribed by Stahl in Cuba. That disease was associated with the leafhopper Peregrinus maidis as vector, both in Cuba and Tanganyka. The author describes 
the disease and his observations on inoculation studies. A similar disease resembling the one under discussion was observed also on sorghum.

\section{Brock, J. A.}

Cause of mosaic disease discovered by science. Facts About Sugar 16(1): 14-15, 1923.

Review of Nelson, Kunkel and Mc Kinney's work, on bodies associated with mosaic disease.

\section{Brooks, A[rchibald] J[oseph]}

Causes of mosaic discovered by science. Facts About Sugar $16: 14-15,1923$.

Popular reference to works by Nelson, Kunkel and MeKinney.

Report on the Agricultural Department, St. Lucia. Imp. Dept. Agric. West Indies Rpt. Agric. Dept. St. Lucia 1918-1919, 32 p., 1920.

Rosette disease investigations. Gambia Dept. Agric. Ann. Rpt. 1927-28: 11-16, 1928.

Annual Report of the Department of Agriculture, Colony of the Gambia, for 1928-29, p. 54, 1929. (Rev. Appl. Mycol. 9(1) : 20, 1930.)

Annual Report of the Department of Agriculture, Colony of Gambia, for the year ending March 31st, 1932, 18 p., 1932.

The rosette of the peanuts is not carried in the seed. Many other plants, such as Petunia, Vinca, Calliopsis, Calendula, Chrysophyllum Cainito and Lagerstroemia, show symptoms. The vectors is Aphis labruri (A. Leguminosae). The author also reports a chlorosis which can be transmitted.

Brooks, C[harles], \& Fisher, D. F.

Jonathan spot, bitter pit and stigmonose. Phytopathology 4 (6): : 402-403, 1914.

Description of these diseases, in that date the true cause of bitter pit was not known.

-

Irrigation and bitter pit. Phytopathology (Abstract) 6(1): 111, 1916.

\section{Brooks, F[rederick] T[om]}

Virus diseases of plants. Nature 112(2826) : 955, 1923.

This paper is a review and discussion of papers by Murphy, Quanjer, Whitehead and Salaman. 


\section{Brown, B[enjamin] $\mathbf{A}$ [rthur]}

The causes of degeneration of Irish potato in Connecticut. Connecticut (Storrs) Agric. Expt. Sta. Bull. 160:325-380, 1929.

The author gives the results of field studies over the period from 1922 to 1928 which shows conclusively that mosaic, leaf roll, spindle tuber and similar diseases are the chief causes of potato degeneracy in Connecticut.

Degeneration of potatoes in Connecticut. Amer. Potato Journ. $7(5):$ 140-142, 1930.

A popular discussion of the subject.

\section{Brown, $\mathrm{N}$ [icholas] $\mathrm{E}$ [dward]}

Abutilon Thompsonii and other species. Gard. Chron. 48:427. 1910.

\section{Brown, W[illiam], \& Blackman, V[ernon] H[erbert]}

Field experiments on the deterioration of the Scotch potato seed in England. Ann. Appl. Biol. 17(1):1-27, 1930.

Data is given of the results obtained in the experiments. The main fact is that virus disease affects to a great extent the potato seed and the early lifting or shading has no marked effect of a purely phy. siological nature.

\section{Bruner, S[tephen] C[ole]}

Notas sobre la enfermedad del mosaico de la caña de azúcar. (Notes on sugar-cane mosaic disease.) Rev. Agric. Com. \& Trab. Cuba 2(9) : 532-533, 1919.

The disease is infectious in character. Healthy plantings became infected from nearby diseased plantings.

La enfermedad del mosaico o de rayas amarillas de la caña de azúcar en Cuba. (The mosaic or yellow stripe disease of sugar cane in Cuba.) Rev. Agric. Com. \& Trab. Cuba 2(9): 437-441, 1919.

Record of the occurrence of the disease and a review.

Algunas observaciones sobre la enfermedad del "mosaico" o "rayas amarillas" de la caña de azúcar. (Some observations on the "mosaic" or "yellow stripe" disease of sugar cane.) Rev. Agric. Com. \& Trab. Cuba 4(6) : 616-620, 1921.

A review of work on resistant varieties in Puerto Rico, Hawaii and Jamaica. Gives a list of susceptible and resistant varieties. 
Exploración biológica y fitopatológica en la Provincia de Pinar del Río. (Biological and fitopathological exploration in the Province of Pinar del Río.) Rev. Agric. Com. \& Trab. Cuba $5(4): 27,1922$.

Records the occurrence of mosaic disease on sugar cane in Taco Taco in the Province of Pinar del Río, Cuba.

Sobre la trasmisión de la enfermedad del mosaico o rayas amarillas en la caña de azúcar. (On the transmission of mosaic or yellow stripe disease of sugar cane.) Rev. Agric. Com. \& Trab. 5(1) : 11-22, 1922.

Bibliografía. La enfermedad de las "rayas amarillas" en la caña. (Bibliography. The sugar-cane "yellow stripe" disease.) Rev. Agric. Com. \& Trab. Cuba 5(2) : 32-33, 1922. A review of a paper by Simonetto.

El mosaico y otras enfermedades y plagas de la caña en Cuba. (Mosaic and other cane diseases and pests in Cuba.) Mundo Azucarero 2(1): 20-27, 1923. (Louisiana Planter 70(22): 452-455, 1923. Rev. Appl. Mycol. 2: 523-524, 1923.)

The mosaic does not appear to spread as rapidly in Cuba as in

Puerto Rico. Recommends the use of resistant and immune varieties.

La enfermedad del mosaico de la caña de azúcar. (Mosaie disease of sugar cane.) Cuba Est. Expt. Agron. Circ. 60, 16 p., 1923. (Facts About Sugar 18(14) : 329, 1924.)

A discussion of conditions in Cuba.

La enfermedad del mosaico de la caña de azúcar. (Mosaic disease of sugar cane.) Argentina, Ind. Azucarera 29(366): 228-237, 1924.

Sobre el daño que ocasiona el "mosaico" a la caña de azúcar. (On the damage eaused by "mosaic" to sugar cane.) Cuba Est. Expt. Agron. Circ. 61: 3-14, 1925.

La situación respecto al "mosaico" de la caña de azúcar en Jamaica. (The situation in regard to sugar-cane mosaic in Jamaica.) Rev. Agric. Com. \& Trab., Cuba 8(1):74-76, 1926. (Agricultura (Santiago de las Vegas) 1(1):160-162. 1925.) 


\section{Brunnich, J. C.}

Report of the Agricultural Chemist. Queensland Dept. Agrie \& Stock, Ann. Rpt. 1923: 28-31, 1924.

Notes on bunchy top disease of bananas.

\section{Bryant, M. W.}

Report on the conference on the phony peach disease held at Memphis, Tennessee, on December 13, 1932. Trans. Illinois Hort. Soc. 66: 217-226, 1933.

Objections to quarantine pointed out. It was argued that the disease is controllable by eradication and destruction of infested trees an? that it is not transmissible by propagation.

Bryce, G.

The "bunchy top" plantain disease. Dept. Agr. Ceylon, Leaflet 18, 2 p., 1923.

Popular.

Buchwald, N. F.

Omm virussy gdomme hos planterne. (On the virus diseases of plants.) Naturens Verdens 1933, p. 447-470, 1933.

Brief historical sketch of researches on virus diseases of plants and discussion of the various aspects of the problem now undergoing investigations. Review of the most recent work.

\section{Bunzel, H[erbert] $\mathrm{H}$ [orace]}

A biochemical study of the curly-top of sugar beet. U.S.D.A. Br. Plant Indus. Bull. 277, 27 p., 1913.

(The role of oxidases in curly-top of sugar beets.) Biochem. Ztschr. 50(3-4) : 185-208, 1913.

Oxidases in healthy and in eurly dwarf potatoes. Journ. Agric. Res. 2(5) : 373-404, 1914.

Chemical and physiological studies with special reference to the oxidase activity of the plants.

Oxidase reaction in healthy and blighted spinach. Journ. Agric. Res. 15(7) : 377-380, 1918.

Report of the results obtained in his studies on the subject. He states that the results obtained resembles those obtained in several other plant diseases. In the case of the mosaic of tobacco, leafcurl of potatoes, eurly-top of sugar beets and eurly dwarf of potatoes the diseased material shows a greater power to transfer atmospheric oxygen to eertain aromatic compounds than the healthy plants. 
72 THE JOURNAL OF AGRICULTURE OF THE UNIVERSITY OF P. $R$.

\section{Burger, O[wen] $\mathrm{F}$ [rancis]}

Report of the Plant Pathologist. Florida Agric. Expt. Sta. Ann. Rpt. 1920-21: 25 R-28 R, 1921.

Brief notes on mosaic disease of several economic plants.

Report of the Plant Pathologist. Florida Agric. Expt. Sta. Ann. Rpt. 1922-23 : 52 R-102 R, 1923.

Notes on mosaic disease of several economic plants. Some of them are records. Sweet potato mosaic is discussed to some extent.

Report of the Plant Pathologist. Florida Agric. Expt. Sta. Rpt. 1924-25, 1925.

First record of eggplant mosaic disease.

\section{Burkholder, W[alter] H[agemeyer]}

Bean diseases in New York State in 1916. Phytopathology (Abstract) $7(1): 61,1917$.

\section{$\mathrm{W}$ [alter]}

\section{Hawley, I[ra] MI[yron,] \& Lindstrom, E[rnest]}

Some results of the New York State bean investigations. Proc. New York Fruit Growers' Ass'n. 17th Ann. Meeting 17:120$125,1918$.

\section{\& Muller, A[lbert] S[tanley]}

Hereditary abnormalities resembling certain infectious diseases in beans. Phytopathology 16(10): 731-737, 1926.

This paper includes a discussion of a disease which resembles mosaic. It is designated as a "pseudo mosaic."

\section{Burnett, G[rover,] \& Jones, Leon K[ilby]}

In contrast with seedling stock, apparently healthy potato tubers are virus carriers. Phytopathology (Abstract) 20(10): 854-855, 1930.

The effect of certain potato and tobaceo viruses on tomato plants.

Washington Agric. Expt. Sta. Bull. 259, 37 p., 1931.

This paper gives the results of very interesting experiments. It is especially valuable for the data on latent viruses.

The distribution of the latent virus in tubers of commereial potatoes. Phytopathology (Abstract) 21(1) : 104, 1931. 
The longevity of the latent and veinbanding viruses of potato in dried plant tissue. Phytopathology 24(3) : 215-227, 1934. (Washington Agric. Expt. Sta. Sci. Paper 257.)

Trials of inoculation of dried inoculum on tobaceo and tomato plant, giving the results.

Stunt-A virosis of Delphinium. Phytopathology 24(5):467481, 1934.

The author describes the disease of Delphinium known as "stunt" or witches broom. The disease has been transmitted mechanically to several species of plants, but the insect vector has not yet been determined.

\section{Busch, Hans J., \& Wolf, Frederik A.}

Manufactured tobaceo, a source of inoculum for mosaic in flue-cured tobacco. Phytopathology 23(10) : 839-841, 1933.

Brief report of the results of investigations of manufactured tobaceo as source of inoculum for mosaic in flue-cured tobacco.

\section{Busch, W.}

Die mosaikkrankheit der Zukerrübe. (The mosaic disease of sugar beet.) Osteurop. Landw. Zeitg 4, No. 6, 1927.

\section{Butler, E[dwin] J[ohn]}

Report on "spike" disease among sandalwood trees. Indian For. App. Ser. 29(1) : 1-11, 1903.

Some characteristies of the virus diseases of plants. British Med. Journ. 1922: 963-964, 1922. (Sci. Prog. 17(67):416431, 1923.)

Classifies the virus diseases into four groups. Gives a general diseussion of the problems.

Virus diseases of plants. Proc. Pan Pacific Sei. Congr. 1:143149, 1923.

Report of some diseases of the tea and tobaceo in Nyasaland. Nyasaland Dept. Agric. Ann. Rpt. 1928: 30, 1929.

\section{Butler; O[rmond Rourke]}

Effect of size of seed used in eommercial planting on the incidence of leaf-roll and mosaic in potatoes. Journ. Amer. Soc. Agron. 22(1) : 75-77, 1930.

A brief record of some experimental work. 


\section{\& Murray, H. L.}

Effect of nitrate of potash on the vigor and productivity of healthy and leaf roll. Green mountain potato plants and their progenies. Journ. Amer. Soc. Agron. 24(11) : 881-887, 1932.

Report of results of experiments. In conclusion it was noticed that nitrate of potash applied to some of the cultures not only increased yields but also resulted in loss of vigor in the progeny of the fertilized piants.

\section{Button, H[arry] $\mathrm{F}$ [reeman]}

Scoundrel in stripes. Gard. Mag. 34:108, 116, 1921.

\section{Caesar, L[awson]}

Peach diseases. Peach yellows and little peach. Ontario Dept. Agric. Bull. 201: 43-59, 1912.

Some little known but destructive diseases reported. Ontario Agric. Coll. \& Expt. Farm. Ann. Rpt. 38:28, 1912.

A record of raspberry yellows and tomato mosaic.

Some data on peach yellows and little peach in Ontario. Phytopathology (Abstract) 10(5):318, 1920.

\section{Caldwell, John}

The physiology of virus diseases in plants. I. The movement of mosaic in the tomato plant. Ann. Appl. Biol. 17(3):429443, 1930.

The movement in the plant of the causative agent of virus disease is discussed. The relevant data in the literature is summarized.

This paper gives the results of experiments which demostrated that the virus it not earried in the xylem.

The physiology of virus diseases in plants. II. Further studies on the movement of mosaic in the tomato plant. Ann. Appl. Biol. 18(3) : 279-298, 1931.

Experiments with aucuba mosaic in tomato are discussed. These results support the general thesis that the causative agent does not normally travel in the xylem stream.

Studies in the physiology of virus diseases in plants. III. Aucuba or yellow mosaic of tomato in Nicotiana ghtinosa and other hosts. Ann. Appl. Biol. 19(2) : 144-152, 1932.

When the aucuba or yellow mosaic of tomato is injected into Nicotiana glutinosa and Datura stramonium the symptoms are different from those produced by this little multiplication of the virus. 
The physiology of virus diseases in plants. IV. The nature of tomato. Ann. Appl. Biol. 20 : (1)100-116, 1933.

The author summarizes this paper as follows: "In this paper the symptoms of aucuba mosaic of tomato in N. glutinosa are described. A method is discussed whereby it is possible to count the spots formed after inoculation with juice diluted to different strengths. The fact that the number of spots formed is proportional to the amount of dilution is taken as indication the number of virus particles present in the juice. It is shown that the amount of virus present in the juice does not increased after agitation or after treatment with proteolytic enzymes. With trypsin and diastase they were decreased. This decrease it is suggested, is due to the absorption rather than to the destruction of the virus. The amount of multiplication of the virus in the tissues of $N$. glutinosa, is examined and compared with the much greater multiplication in tomato tissues.

The physiology of the virus diseases in plants. V. The movement of the virus agent in tobaceo and tomato. Ann. Appl. Biol. 21(2) : 191-205, 1934.

The author reports the results of experiments on the movement of the virus of aucuba or yellow mosaic of the tomato. Also of experiments on the transmission of six different viruses in the seed of tomato or tobacco, which were negative. The author suggests that the chances of seed transmission of these viruses are very slight. Other observations are given and concludes that the virus apparently moves in the direction opposite to that of the metabolites.

The physiology of virus diseases in plants. VI. Some effects of mosaic on the metabolism of the tomato. Ann. Appl. Biol. $21(2)$ : 206-224, 1934.

The author revises the literature dealing with the effect of virus diseases on the metabolism of the host plants. He reports the results of his experiments and observations on the aucuba or yellow mosaic in tomato. According to the author the metabolism of the plant is not affected during the stage of development. He found that the respiration process is somewhat affected by the disease, the output of $\mathrm{CO} 2$ by the host tissues is higher than the healthy ones. This is attributed to an increase in the efficiency of the enzyme system of the diseased plants.

\section{Calinissa, M. R.}

The occurrence of bunchy-top and root-knot in Abacá. Phil. Jour. of Agric. 2(2) : 121-127, 1931.

Plants of Musa textilis may be infected with both diseases which causes some confusion. 
Attempts to re-establish abacá plantation in Cavite, previously wiped out by bunchy top. Philippine Journ. Agric. 2(3): 209-221, 1931.

The efforts have not been encouraging. Ten introduced varieties are more of less susceptible. The use of fertilizer was not successful.

Caluwe, P. de

(The leaf curl of potatoes.) Handel. Vlaamsch Natuur en Geneesk Cong. 12(2) : 195-200, 1922.

\section{Calvino, Mario}

Informe de los años 1918, 1919 y 1920 de la Estación Experimental Agronómica, Santiago de las Vegas, Cuba. (Annual Report for the years 1918, 1919 and 1920 of the Agricultural Experiment Station, Cuba), pp. 547-550, 1920.

Doce puntos relacionados con el mosaico de la caña y el modo de combatirlo. (Twelve points related to sugar cane mosaic disease and methods to control it.) Rev. Agric. Com. \& Trab. Cuba, 5(12) : 6-7, 1924.

Nuevas orientaciones en la selección de caña para semilla. (New orientations in sugar cane seed selection.) Rev. Agric. Com. \& Trab. Cuba, 5(12) : 8-10, 1924.

\section{Campbell, D. Curl}

Communications to the Board of Agriculture. 3:219, 1802.

\section{Campbell, E[lmer] G[rant]}

Potato leaf-roll as affecting the carbohydrate, water and nitrogen content of the host. Phytopathology 15(7) : 427-430, 1925.

A brief paper giving the results of studies indieated in the title.

\section{Camuñas, IManuel}

Report of the Commissioner of Agriculture and Labor, 19th Ann. Rpt. Govt. Porto Rico to Secretary of War, Washington, D. C., Appendix LX pp. 685-707, 1919. (Rev. Appl. Ent. ser. A. 9:332, 1919.)

A record of the occurrence of mosaic of sugar cane in Puerto Rico.

\section{Carne, W[alter] M[illard]}

Spotted wilt of tomatoes. W. Australia Dept. Agric. Leaflet 116, 1923.

Popular. 
Lithiasis and bitter pit of pears. Journ. Dept. Agric. W. Australia 2 Ser. 4(2): 202-206, 1927.

Description of these two diseases before the cause was known.

Mosaic and leaf roll of potatoes. Journ. Dept. Agr. W. Australia 2 Ser. 4(2) : 322-329, 1927.

Bitter pit in apples: Some recent investigations. Journ. Australian Council Sci. \& Indus. Res. 1(6) : 358-365, 1928.

Report of recent observations. This work was done before the eause was known.

A preliminary note on a theory as to the origin of bitter pit in apples. Journ. Dept. Agric. W. Australia 2 Ser. 4(3): 382-385, 1927.

The author attributes the bitter pit of apples to excessive transpiration. He explains his conclusions, written before the cause was known.

Pittman, H. A., \& Elliot, H. G.

Studies concerning the so-called bitter pit of applies in Australia, with special reference to the variety Cleopatra. Australia Council Sci. \& Indus. Res. Bull. 41, 88 p., 1929.

This is a preliminary report. It reviews the literature, describes the disease, and gives control measures. This paper was written before the true cause of the disease was known.

Carpenter, C[larence] W[illard]

The Río Grande lettuce disease. Phytopathology 6:303-305, 1916.

The first record of this disease.

\section{Carrante, Vicenzo}

La produzione della patate da semente e le malattie da virus. (Potato production by seed and the virus disease.) L'Italia Agricola 11(4) : 439-463, 1933.

A well illustrated popular paper giving good deseription.

Carroll, E.

On the disease in potatoes called curl. Irish Farmers' \& Gard. Mag. 4: 248-251, 1837.

Historical.

\section{Carriére, E. A.}

Revue Horticole 52:444, 1880.

Mention of Pittosporum tobira variegata. 
Influence du greffon sur le sujet. (Influence of the graft upon the stock.) Rev. Hort. 59:58-59, 1887.

Mention of Pittosporum tobira variegata, Ilex, Rhammus, Acer psondoplatanus var. cuchlora.

Resistance in sugar beet to curly-top. Phytopathology (Abstract) 16(1): 87-88, 1926.

\section{Carsner, Eubanks}

Susceptibility of various plants to curly top of sugar beet. Phytopathology 9(9) : 413-421, 1919.

The author gives a list of susceptible plants obtained by experimental studies.

\section{, \& Stahl, C[owins] F[loyd]}

The relation of Chenopodium murale to curly-top of the sugar beet. Phytopathology (Abstract) 14(1): 57, 1924.

\section{- - - - - - - -, \&}

Progress report on curly-top of sugar beet. Phytopathology (Abstract) 14(2) : 122-123, 1924.

\section{- - - - -}

Studies on curly-top disease of the sugar beet. Journ. Agric. Res. 28(4) : 297-319, 1924. (Facts About Sugar, March 1925.) Gives review of the literature, the distribution of the disease and the leafhopper. Discusses the importance of the disease, the incubation period in the insect, the relation of the number of insects to the disease, the effects of. light and temperature, susceptibility, other hosts overwintering and methods. of control.

Spring infection of sugar beet leafhopper with curly-top virus. U.S. D. A. Official Rec. No. 34, 3 p. 1925.

A bean disease caused by the virus of sugar beet curly-top. Phytopathology (Abstract) 15(11): 731, 1925.

Attenuation of the virus of sugar beet eurly-top. Phytopathology $15(12)$ : 745-756, 1925.

Chenopodium murals, Rumex crispus and Sualda moquini are difficult to infect. The attenuation of the virus from these plants does not give immunity to beets.

Resistance in sugar beet to curly top. U.S.D.A. Circ. 388, 7 p., 1926. 
Based on the evidence reported the author hopes to find a resistant variety of beet to curly top.

Susceptibility of the bean to the virus of sugar-beet curly-top. Journ. Agric. Res. 33(4) : 345-348, 1926.

Brief account on the susceptibility of bean to the virus of sugarbeet curly-top, transmitted by the leafhopper Eutettix tenella Baker. Description of symptoms and enumeration of susceptible varieties of beans.

\section{\& Lackey, C[harles] F[ranklin]}

Further study on attenuation of the virus of sugar beet curlytop. Phytopathology (Abstract) 18(11): 951, 1928.

Mass action in relation to infection, with special reference to curly-top of sugar beet. Phytopathology (Abstract) 19(12) : 1137, 1929.

Abegg, F. A., Cormany, C. E., Elcock, H. A., Keller, W., Lowe, C. C., Owen, F. V., Park, D. A., Price, C., \& Skuderna, A. W.

Curly-top resistance in sugar beets and tests of the resistant variety U. S. No. 1. U.S. D. A., Tech. Bul. 360, 68 p., 1933. Gives the results of experimental work with this important variety.

\section{Carter, Walter}

Population of Eutettix tenellus Baker and the osmotic concentration of its hosts plants. Ecology 8:350-352, 1927.

The author does not discuss virus diseases, but this insect is of interest in connection with curly-top of sugar beet.

Extensions of the known range of Eutettix tenellus Baker and curly-top of sugar beets. Journ. Econ. Ent. 20 : 714-717, 1927.

A record of an outbreak of eurly-top of sugar beet in Montana and an abundance of the insect vectors.

Ecological studies of curly-top of sugar beets. Phytopathology (Abstract) 17(10): 747, 1927.

A technic for use with homopterous vectors of plant diseases with special reference to sugar-beet leafhopper, Eutettix tenellus. Journ. Agric. Res. 34(5)449-452, 1927.

A description of a device for artificial feeding of the insects. 
An improvement in the technique for feeding homopterous insects. Phytopath. 18(2): 246-247, 1928.

A very short paper in which the author describes the method.

Transmission of the virus of curly-top of sugar beet through different solutions. Phytopathology 18(8) : 675-679, 1928.

The author gives the results of experiments with leafhoppers as transmitting agents.

The purpose of predicting outbreaks of Eutettix tenellus Baker under present-day conditions. Journ. Econ. Ent. 22(1) : 154158, 1929.

A study which is of value in connection with the study of the curlytop of sugar beets.

Seasonal and regional variations in curly-top of sugar beets. Science 63(1625) : 213-214, 1926.

Observations indicate "That the abundance or searcity of beet leathoppers and presumably also the climatic conditions of a given area rather than the severe outbreaks occurred simultaneously throughout the range of the insects at periodic intervals."

Susceptibility of the virus of sugar beet curly-top. Journ. Agric. Res. 33(14) : 345-348, 1926.

The author gives proof that a disease of the beans is caused by the same virus as that causing the curly-top of the sugar beet and that it is earried by the insect (Eutettix tenella.)

Curly-top problems from the pathological standpoint. Utah Agric. Expt. Sta. Misc. Publ. No. 3, 1927.

Ecological studies of eurly-top of sugar beet. Phytopathology $19(5): 467-477,1929$.

"'The development of curly top appears to be more severe under conditions of high light intensity, temperature, and evaporation than under conditions where these factors are reduced in intensity. One experiment indicates that the conditions governing susceptibility to in fection are not the same as those conditioning the later development of the disease. Experiments on the control on external environment indicate that lampblack and zine oxide when sprayed onto the leaves, interfered with the normal functions of the plant and did not favor the development of the disease. Hydrated lime reduced the severity of the disease but did not affect the normal beet." 
Ecological studies of the beet leaf-hopper. U. S. Tech. Bull. 206: 114 p., 1930.

This paper does not deal with any virus disease but is of interest because the insect is a carrier of the curly-top of the sugar beet.

Some phases of the sugar-beet leaf-hopper problem. Journ. Washington Acad. Sci. 20:153-155, 1930.

Comparison of tobacco dust with other forms of nicotine in control of yellow spots of pineapples. Journ. Ecom. Ent. $25(5)$ : 1031-1035, 1932.

Tobaceo dust was superior to other nicotine preparations in the control of the vector (Thrips tabaci).

The pineapple mealybug (Pseudococcus brevipes (Ckl.) and wilt of pineapples. Phytopathology (Abstract) 22(12) : 996997, 1932.

The spotting of pineapple leaves caused by Pseudococcus brevipes (Ckl.) the pineapple mealybug. Phytopathology (Abstract) $22(12): 996,1932$.

The pineapple mealybug, Pseudococcus brevipes and wilt of pineapples. Phytopathology 23(3) 207-242, 1933.

The author gives excellent description of this disease and the results of experimental work by which he demonstrated that the disease is carried by this insect. There is no positive proof that this disease is due to a virus.

The spotting of pineapple leaves caused by Pseudococcus brevipes the pineapple mealy bug. Phytopathology 23(3): 243-259, 1933.

This insect causes two types of spots and it is not known that either of them is due to a virus. The power to cause green spots is transmitted from mother to young but not all the young ones have the power to transmit the disease.

\section{Casagrandi, 0.}

Virus filtrabili ed ultrafiltrabili (Tecnica e ricerche personnali). (Filterable and ultrafilterable viruses. Personal technique and researches). Bull. Atti. A. Acad. Med. Rome. 52(9) : 285288; (10) : 340-344, 1926. 


\section{Cation, Donald.}

Three virus diseases of the peach in Michigan. Michigan Agric. Expt. Sta. Cire. Bull. 146: 2 p., 1932.

A brief historical review of yellow and little peach and a description of a new virus disease to which he gives the name "red suture."

\section{Cayley, Dorothy III.}

"Breaking" in tulips. Gard. Chron. 83(2164) : 435-436, 1928. (Ann. Appl. Biol. 15(4) : 529-539, 1928.)

The author gives the results of experiment proving that the disease is infectious and transmissible.

Ecological studies of eurly-top of sugar beets. Phytopathology $19(5): 467-477,1929$.

A discussion of the environmental factors under which the symptoms are increased or decreased.

Ecological studies of the beet leafhopper (Euteftix tenella).

U. S. D. A., Tech. Bull. 806, 114 p., 1930.

This paper does not contain any data on virus diseases but is of interest because of the relation of the insect to the curly top of sugar beet.

"Breaking" in tulips. II, Ann. Appl. Biol. 19(2) : 153-172, 1932.

The disease is transmitted by grafting and by inserting plugs of diseased tissue into healthy bulbs. Experiments with filtered sap, have given negative results. Experiments of transmission to promote breaking have given negative results. The variety Keizerskroon is a true bicolor and the pattern is not of a virus.

Ceresa, G.

Control de la enfermedad del "Mosaico", (Mosaic disease con. trol). Rev. Agric. Com. \& Trab. Cuba 8(1): 5-9, 1926.

\section{Chapman, G[eorge] H[enry]}

Investigation relating to mosaic disease. Massachusetts Agric. Expt. Sta. Ann. Rpt. $20: 136-144.1908$.

Compares tomato and tobaceo mosaic, describes the former, gives results of studies with fertilizers and on the catalase of the plant. Also discusses susceptibility.

Mosaic allied diseases, with especial reference to tomato and tobacco. Massachusetts Agric. Expt. Sta. Ann. Rpt. 25: 94-104, 1913. 
Tobaceo mosaic eauses losses of more than one million dollars. Tomato mosaic in greenhouses only, and of little importance. Disease is physiological and may be caused by injuries to roots, improper sterilization of the seedbeds, etc. Not caused by mineral fertilizers. Infectious. Not contagious.

Effect of colored light on the mosaic disease of tobacco. Science n.s. 43(1111) : 537-538, 1916.

Gives the results of experiments to determine the effects of colored lights on tobacco mosaic. This is discussed more fully in Bull, 175 published in 1917.

Mosaic desease of tobacco, Massachusetts Agric. Expt. Sta. Bull. 175 : 75-117, 1917.

An extensive study giving a historical summary, a deseription of the disease, occurrence, economic importance, infectious nature, pathological anatomy of plant, methods of transmission, the effects of fertilizer and colored lights. Also a study of the enzyme activity of the plants. Believes the disease is due to a disturbance of the enzyme activities.

\section{Chapple, J.}

A method of potato management for preventing the curl. Path. and West of England Soc. Papers $7:$ 350-351, 1795.

Historical value.

\section{Chardon, Carlos $\mathbf{E}$ [ugenio]}

Informe anual del Patólogo Especial para el año fiscal de 1921-22. (Annual report of the Special Pathologist for the Fiscal year 1921-22.) Ins. Expt. Sta. Porto Rico Ann. Rev. 1921-22 : 67-74, 1922.

Resumen de la literatura del origen de las enfermedades del "Mosaico" en las plantas. (Review of the literature about the origin of "Mosaico" diseases of the plants.) Rev. Agric. Puerto Rico 9(4) : 13-22, 1922.

A review of the literature and list of publications.

\section{\& Veve, R[afael] A.}

Sobre la transmisión del matizado de la caña por medio de insectos. (About the transmission of sugar cane mosaic by means of insects.) Memoirs Ass'n, Sugar Tech. Porto Rico 1(1) : 9-12, 1922. (Rev. Agric. Porto Rico 9(2) : 9-20.) 1922. Facts About Sugar 15(14) : 281-284, 1922. Louisiana Planter \& Sugar Manuf. 69(19) : 323-324, 1922.

Give the results of experiments which proved that Aphis maides is a carrier. 
The transmission of sugar cane mosaic by Aphis maides under field conditions in Porto Rico. Phytopathology 13(1) : 24-29, 1923. (Rev. Appl. Mycol 2 : 390-391, 1923. Rev. Appl. Ent. ser. A. $12(2): 40,1924$. Rev. Agric. Com. \& Trab. (Cuba $7(2)$ : $37-41,1924$.)

This paper gives the results of experiments which demonstrate that the disease is carried by Aphis maides. Also some grass host of the disease. The same discussion in the preceding article.

La relación de ciertas yerbas con el matizado de la caña de azúcar. (Relation of certain weeds with sugar cane mosaic.) Rev. Agric. Puerto Rico 12 : 305-314, 1924. (Rev. Appl. Ent. ser. A. $12(2): 40,1924$.) Rev. Agric. Com. \& Trab. (Cuba) $7(2): 37-41,1924$.)

A study of the disease with special reference to Aphis maidis and certain grass hosts.

La transmisión del mosaico. (Transmission of mosaic.) Sugar 25 : $477-478,1924$.

Mosaic investigations at Central Cambalache. (Preliminary Report). Journ. Dept. Agric. Porto Rico 8(2) : 27-39, 1924, (Int. Sugar Journ. 27 (324) : 649-651, 1925. Rev. Appl. Mycol. 4: 505-506, 1924. Rev. Agric. Puerto Rico 13: 205-218, 1924. Facts About Sugar 19:569, 1924.)

"Mosaic" o matizado de la caña de azúcar. ("Mosaic" or mottling of sugar cane.) Rev. Agric. Puerto Rico 14:188197, 1925. (Rev. Appl. Mycol. 4:635, 1925.)

La revolución de las variedades de caña en Puerto Rico. (The varietal revolution of Sugar cane in Porto Rico.) Rev. Agric. Puerto Rico 18:117-127, 1927. (Rev. Appl. Mycol, 6:581, 1927. Planter \& Sugar Manuf. 78(22):429-430; (23) : 451453, 460, 1927. Journ. Dept. Agric. Porto Rico 11: 9-41, 1927.)

This paper includes a discussion of the relation of mosaic to the varietal revolution of sugar cane in Porto Rico.

The agricultural revolution in Porto Rico. Facts About Sugar 22 : 894-897, 1927. 


\section{Chatterju, N. C., et al}

Investigations on the spike-disease of Sandal. I. Résumé of the observations made to date. II. Report of progress made during the quarter ending 30th June, 1931, Indian Inst. of Sci. Bangalore, 16 p., 1931.

A review of the history of the disease and a sketch of recent work,

\section{Cheal W[illiam] F[rank]}

Investigations of hop mosaic disease field. Ann. Appl. Biol. $16(2): 230-235,1929$.

Proof that the disease is infectious and can be introduced by carrier plants.

\section{Chevalier, Aug[ust]}

Sus l'extension et la propagation de la maladie de la rosette d'Arachide au Senegal. Comp. Rend. Acad. Sci. (Paris) 193 (22) : 1115-1117, 1931.

The virus of the peanut rosette is transmitted by Aphis laburni. Tha disease also attacks the Sakhagayer, a peanut growing on fallow land. This appears earlier than the cultivated peanut and carries the disease from year to year.

\section{Chiel, The}

Stripe sick cane. South Africa Sugar Journ. 9:439-440, 1925.

The author believes that the stripe disease is a form of mosaic.

\section{Christie, G[eorge] I[rving]}

Report for 1921 of the Department of Botany. Indiana Agric. Expt. Sta. Ann. Rpt. 1921: 14-19, 1921.

Chu, H.

(The speciality of mosaic disease.) Ent. \& Path. Hangchow, China 2(12) : 219-240, 1934.

\section{Church, Margaret B [rooks]}

The relation of mosaic disease to pickling of cucumber. Phytopathology 11(1) : 28-29, 1921.

A study of the effect of the disease on the pickling quality of the eucumber.

\section{Ciferri, $R$ [afael]}

Measuring the intensity of discoloration of sugar cane leaves. Proc. Fourth Congr. Intern. Sec. Sugar Cane Technologists, 1932. (Facts About Sugar (Abstract) 27(6) : 260, 1932.)

The author describes his procedure and observations with the Moil nephelo-absortimeter while measuring the intensity of light through 
leaves of "Cristalina", variety of sugar eane which is susceptible to mosaic. The infected leaves showed that the opacity is about $27 \%$ greater than that of healthy foliage and practically eonstant.

Thickness of mottled and healthy sugar cane leaves. Proc.

Fourth Intern. Congr. Soc. Sugar Cane Technologist, 1932. (Facts About Sugar (Abstract) 27(6):260, 1932.)

Based on 17,620 micrometric measurements with galvanometric control of the trickness of mottled and healthy leaves of sugar cane varieties susceptible to mosaic. He observed that the diseased leaves are slightly thicker than the healthy ones.

\section{Cláusen,}

Die Blattrollkrankheit der Kartoffel. (The leaf roll disease of potato.) Märkischer Landwirt. 3:503, 1922. (Landw. Wochenbl. Schlezw. Holst. 72:587, 1922.)

\section{Clayton, $\mathbf{E}[$ dward] $\mathbf{E}$ [astman]}

Effect of early spray and dust applications on later incidence of cucumber wilt and mosaic diseases. Phytopathology 17 (7) : 473-481, 1927.

The most important vector is the striped beetle. Bordeaux and lead arsenate sprays led to a reduction in the mosaic due to control of insects. The spray treatments were better than the dust treatments.

Breeding for resistance to cucumber mosaic disease. Phytopathology (Abstract) 19(1): 85-86, 1929.

A study of the mosaic disease of erucifers. Journ. Agric. Res. $40(3): 263-270,1930$.

The mosaic of swede turnips (Brassica napobrassica) does not appear to be serious. It is carried by the cabbage aphid (Breviocoryne brassicae). Cauliflower and Brussel sprouts are slightly susceptible. Cabbage is highly resistant or immune. Chinese cabbage (B. chinensis), cultivated white (B. alba) and black mustard (B. nigra) and rape (B. napus) are susceptible. The symptoms vary on different hosts and are usually most severe at 65 to 75 degrees F.

Cucumber disease investigations on Long Island. New York (Geneva) Agric. Exp. Sta. Bull. 590, 20 p., 1931.

Conclusions are given that the only way of entrolling mosaic, tho ehief cause of the decline of cucumber in Long Island, is by develoring resistant varieties. 
Cleare, IL[aurence] D[elaney] Jr.

Report of the Biological Division. British Guiana Dept. Agric. Ann. Rpt. 1924: 65-68, 1926. (Rev. Appl. Ent. ser. A. 14: 238, 1926.)

\section{Cleveland, C[larence] R[ugg]}

The relation of insects to the transmission of potato leafroll and tomato mosaic in Indiana. Indiana Agric. Expt. Sta. Bull. 351, 24 p., 1931.

The author gives a relation and importance of insects as carriers of diseases, especially on tomato and potato. He gives methods of control and spraying schedules.

The relation to the transmission of potato leafroll and tomato mosaic in Indiana. Indiana Agric. Expt. Sta. Bull. 351, 24 p., 1931.

Considerations as to the different degrees of importance of the different insect vectors, e. g. the aphid Myzus persicae, the leafhopper Empoasca fabea, the pink and green potato aphids Macrosiphum solanifolii (M. gei) and the flea beetle Epitetrix cucumeris in the spread of mosaic on potato. In regard to tomato mosaic $M$. persicae is believed to be mainly responsible for transmission from tomato to tomato the potato leafhopper, Empoasea fabea, the onion thrips Thrips tabaci and the common red spider Tetranychus telarius are considered capable of transmitting tomato mosaic.

\section{Cleveland, L[emuel] $\mathbf{R}$ [oscoe]}

Some problems that may be studied by oxygenation. Science 63 : 168-170, 1926.

The author suggests the studying of a large number of diseases, including virus diseases by a method of oxygenation.

\section{Cleveringa, 0 . J.}

Verschillende belangrijke ounten voor het pootgoedoraagstuk bij aardappelen, in her vijzonder ook de rol die de afdeel. ingen, (del landbouwmaatsppijen) daarbij Kunnen vervullen. Tijdschr. Plantenz. 30(2): 17-26, 1924.

Certified seed gave good yield the first year but there was a rapid decrease the following years as a result of infection by virus diseases.

\section{Clinch, Phillis}

Cytological studies of potato affected with certain virus diseases.

Sci. Prov. Roy. Dublin Soc. 20 (15) : 143-172, 1932.

Detailed account of the author's cytological investigations of potato plants affected with certain virus diseases. Those types considered were: simple mosaic, crinkle, interveinal mosaic, aucuka mosaic, streaki, and leafroll. 


\section{Clinton, G[eorge] P [erkins]}

Chlorosis troubies. Illinois Agric. Expt. Sta. Bull. 40, p. 139, 1895.

Chlorosis troubles, aster, peach, raspberry yellows and tobaceo calico. Connecticut Agric. Expt. Sta. Ann. Rpt. 1903: 305, 341, 355, 363, 1903.

Gives record of mosaic disease on many plants.

Report of botanist. Connecticut Agr. Expt. Sta. Rept. 1905 : 270-273, 1906.

Deseription of a disease of onions called brittle on account of the brittleness of the leaves; although not described as a virus disease it appears as an early record of the disease which recently has been proved to be due to a virus and known as dwarf.

Lima bean chlorosis and tobacco calico. Connecticut Agric. Expt. Sta. Ann. Rpt. 1907: 341, 362, 1907.

Gives record of mosaic disease in many plants.

Notes on fungus diseases etc. for 1908. Connecticut Agrie. Expt. Sta. Ann. Rpt. 1908: 857-858, 865-866, 872-979, 1909.

Muskmelon chlorosis and mosaic diseases on several plants. Peach yellows and so-called yellows.

Thirty-third and Fourth Reports of the Botanist. Connecticut Agric. Expt. Sta. (New Haven) Rpt. 33-34: 735, 1910.

Gives record of mosaic disease in many plants.

Tobaceo calico. Connecticut Agric. Expt. Sta. Bull. 166:10. 1913.

String leaf tobaceo. Connecticut Agric. Expt. Sta. Ann. Rpt. $1913: 27,1913$.

Gives record of mosaic disease in many plants.

Chlorosis of plants with special reference to ealico of tobaceo.

Connecticut Agric. Expt. Sta. Ann. Rpt. 1914: 357-423, 1915.

Gives a discussion of types of ehlorosis, nomenclature, host prevalence, distribution, review of literature and results of his own experiments.

Mosaic or white pickle. Connecticut Agric. Expt. Sta. Ann. Rpt. 1915 : 430-431, 1916. 
A record. Also a record of chlorosis and erinkling of soy bean on page 446 .

Notes on plant diseases of Connecticut. Connecticut Agric. Expt. Sta. Rept. 1915(6) : 421-451, 1916.

Contains records.

New or unusual plant injuries and diseases found in Connecticut. 1916-19. Connecticut Agric. Expt. Sta. Bull. 222: 397-482, 1920.

Records of ehlorosis on Celastrus scandens and Ribes vulgare.

Peach "Yellow" Nature and cause of mosaic disease of plants. Connecticut Agric. Expt. Sta. Director's Rpt. 1924 : 207, 1925. Very brief reference.

\section{\& Anderson, P. J.}

Tobacco diseases observed in 1926. Connecticut Agric. Expt. Sta. Tobacco. Sta. Bull. 8:55T-57T, 1927.

\section{\& IIcCormick, F[lorence A.]}

Tobaceo mosaic. Connecticut Agric. Expt. Sta. Tobaceo SubSta. Bull. 10: 75T-82T, 1928.

\section{Cockerham, G.}

Variations in the total nitrogen content of normal and leafroll potatoes. Proc. Leeds. Phil. \& Lit. Soc. (Sci. Sect.) 2(8): 375-382, 1933.

Considerations of the pronounced disturbances in the metabolism of nitrogenous substances within the potato due to the presence of the leafroll virus. Discussion of results obtained with a great deal of tabulated data.

Coit, J. E.

Sun-blotch of the avocado, a serious physiological disease. California Avocado Assoc. Yearbook, p. 27-32, 1928.

This paper was written before it was demonstrated that the disease was due to a virus.

\section{Colby, A. S., \& Anderson, H. W.}

Diseases of brambles in Illinois and their control. Illinois Agric. Expt. Sta. Circ. 305, 1926.

Several virus diseases of brambles are deseribed. 


\section{Coleman, Leslie C[harles]}

Spike disease of sandal. Mysore State Dept. Agric. Mycol. ser. Bull. 3, 52 p., 1918.

After discussing the conditions under which the disease appeared the author concludes that it is a virus disease comparable to other virus diseases in behavior and that it is communicated by grafting and insects. The accumulation of starch in the leaves and the dying of root tips and haustoria are definite symptoms. This appears to be the first paper giving evidence that the disease is caused by a virus.

Transmission of sandal spike. Indian Forester 49(1): 6-9, 1923. Gives proof by means of grafting that this disease is due to a virus.

\section{Colón, E[mundo] D[imas]}

La enfermedad de las rayas amarillas. (Yellow stripe disease.) Porto Rico Ins. Expt. Sta. Circ. 14: 3-6, 1918.

Popular account of this disease new to Porto Rico.

Yellow stripe of sugar cane. Porto Rico Ins. Expt. Sta. Ann. Rept. 1918-19: 66-68, 1919.

The absorption spectrum of the chlorophyll in yellow striped sugar cane. Journ. Dept. Agric. Porto Rico. 3(4) : 43-53, 1919.

These studies indicated that there is no decomposition of chlorophyll.

La enfermedad de las rayas amarillas. (Yellow stripe disease.) Sugar 21: 52, 1919.

A brief popular diseussion.

Trabajos de investigación durante el año Fiscal 1919-20. Research work during the Fiscal year 1919-20. Rev. Agric. Puerto Rico 6(3) : 7-14, 1921. Rico.

A review of work done at the Insular Experiment Station of Puerto

Chemical changes in yellow striped sugar cane. Porto Rico Ins. Expt. Sta. Ann. Rpt. 1920-21:18-19, 1921.

\section{Condit, I[ra] [Judson], \& Horne, W[illiam] T[itus]}

A mosaic of the fig in California. Phytopathology (Abstract) 23(1): 7. 1933. 
Account of a disease which appears to be a true mosaic of fig. No insect vector of the disease has been detected. Transmission is discussed.

A mosaic of the fig in California. Phytopathology 23(11) : 887896, 1933.

A more detailed account than the preceding abstract and well illustrated. The authors discuss mosaic symptoms, variety susceptibility, vectors and field laboratory studies.

\section{Cook, IIelville T[hurston]}

Peach yellows and little peach. Bot. Gaz. 72(4) : 250-255, 1921.

Gives the results of histological studies to determine the translocation of starch.

The dissemination of peach yellows and little peach. Phytopathology 12 (3) : 140-141, 1922.

Evidence that these diseases are transmitted in nursery stock.

Estudio sobre la causa del matizado. (Studies on the cause of mottling.) Rev. Agric. Puerto Rico 13(6):373-376. 1924. (Rev. Appl. Mycol. 4:378, 1924).

A discussion of virus diseases with special reference to sugar cane mosaic.

The search for the cause of mosaic. Facts About Sugar 19(24): 570-571, 1924.

A popular paper.

Present knowledge of mosaic disease. Journ. Dept. Agric. Porto Rico 8(2):50-54, 1925, (Int. Sugar Journ. 27(324); 647-648, 1925.)

Popular.

Studies on the cytology of sugar cane mosaic. Phytopathology (Abstract) 15(1): 45, 1925.

The control of sugar cane mosaic. Facts About Sugar 20(30): 67-68, 1925.

A popular discussion of the disease in Porto Rico.

El dominio del matizado de la caña de azúcar. (The control of sugar cane mosaic.) Rev. Agric. Puerto Rico 14(1) : 7-9, 1925.

A popular discussions of the disease in Porto Rico. 
Histology and Cytology of sugar cane mosaic. Journ. Dept. Agric. Porto Rico 9(1):5-27, 1925. (Rev. Appl. Mycol. 5: 387-388, 1925. Rev. Agric. Porto Rico 15:291-293, 1925.)

The author gives a review of the literature on this phase of the subject and the results of his own studies. The chlorosis areas are slightly thinner than the green areas. The green areas are the same as a healthy leaf of the same age. The intracellular bodies are present but difficult to find. Chloroplasts are smaller and fewer in chlorotic than in healthy cells.

Sugar production and cane diseases. Facts About Sugar 20 (45) : 1068-1069, 1925. (Rev. Appl. Mycol. 5:187, 1925. Rev. Agric. Puerto Rico 15 : 273-276, 1925).

Popular.

El mosaico de la caña de azúcar en Puerto Rico. (Sugar cane mosaic in Porto Rico). Rev. Agric. Puerto Rico 17(5):6, 13, 1926. (Facts About Sugar 22(9): 203, 1927. Rev. Appl. Mycol. 6:318-319, 1926.)

Popular.

Photo-synthesis of the sugar eane plant. Journ. Dept. Agric. Porto Rico 10(3-4) : 239-242, 1926. (Rev. Appl. Mycol. 7: 198, 1926.)

The author reviews the literature on this phase of the subject and makes comparative studies of sugar-cane mosaic with his previous studies on peach yellow and little peach. In the ease of sugar cane the chlorotic areas do less photosynthetic work than the green areas but the translocation of carbohydrates is normal. In the case of peach yellows and little peach the translocation of carbohydrates is almost or completely inhibited.

Relationship of cane varieties to diseases. Journ. Dept. Agric. Porto Rico 9(4):277-282, 1926. (Rev. Appl. Mycol. 6:376, 1926.)

Contains a brief reference to mosaic.

The effect of mosaic on the content of plant cell. Journ. Dept. Agric. Porto Rico 10(3-4):229-238, 1926. (Rev. Appl. Mycol. $7: 197,1928$.

The author gives a review of the literature and the results of his own studies. The chlorotic areas are indistinct in the very young leaves. They became distinct with exposure to light. Later the chlorotic areas tend to become green. The chloroplasts are smaller and 
fewer in number than in the green areas, but increase in size and number with age. The chlorotic areas increase in size as a result of cell growth and cell division and not by the encroachment of the virus on the surrounding cells. The nuclei are usually enlarged and deformed.

Some effect of mosaic on the contents of the cells. Phytopathology (Abstract) 17(1):57, 1927.

The effects of some mosaic diseases on the cell structure and the chloroplasts. Phytopathology (Abstract) 20(1):142, 1930 .

The effect of some mosaic diseases on cell structure and on the chloroplasts. Journ. Dept. Agric. Porto Rico 14(2) : 69-101, 1930.

The author gives a review of the literature and the results of his own studies which are a continuation of previous studies in which he has used sugar cane, canna, tobacco, tomato and cowpea. The chlorotic areas are thinner than the green areas. The active agent inhibits the differentiation of the cell structure and of the chloroplasts. The earlier the attack, the greater the inhibition. The active agent does not penetrate the various parts of the leaf equally. The result is the chlorotic areas and variations in cell differentiation. There is no reason to believe that structure and development of chloroplasts are modified by the virus. It is a true case of inhibition. The development of cell structure is permanently checked but the chloroplasts of the chlorotic areas increase in size and number.

Distribución geográfica de las enfermedades de la caña de azúcar. (Geographical distribution of sugar cane diseases. Rev. Agric. Puerto Rico 25(5) : 170-172, 1930. (Facts About Sugar 26(1) : 24-26, 1931.)

A chart is given with explanatory notes showing the distribution of sugar cane diseases throughout the world.

La situación actual en enfermedades de la caña de azúcar en Puerto Rico. (The present situation of sugar cane diseases in Porto Rico.) Rev. Agric. Puerto Rico 24(12) : 227-231, 1930 .

Brief notes on sugar-eane mosaic disease in Puerto Rico. Advocates Prof. Earle's recommendations in regard to control methods, i.g. "roguing" and the planting of immune or resistant varieties. 
94 THE JOURNAL OF AGRICULTURE OF THE UNIVERSITY OF P. I.

Enfermedades de la caña de azúcar en Puerto Rico. (Sugar cane diseases in Porto Rico.) Ins. Expt. Sta. Puerto Rico, Circ. 94: 14-19, 1931.

Sugar-cane mosaic disease is the most important in Puerto Rico. In this paper the author discusses briefly the disease. Includes a short list of grasses which are also suseeptible to sugar-eane mosaic.

Undescribe symptoms of mosaic in Porto Rico. Phytopathology (Abstract) 21(1):117, 1931.

New virus diseases in Porto Rico. Phytopathology (Abstract) 21(1) : 124, 1931.

Some unreported virus diseases are briefly described. 1. A mosaic of Crotalaria striata; 2. A rare mosaic of Commelina longicaulis; 3. A bunchy-top of Carica Papaya; 4. A variegation of Abutilon hirtum; 5. A variegation of several species of Sida; 6. A mottling of mulberry.

Some undescribed symptoms of mosaic in Porto Rican Tobacco. Journ. Dept. Agric. Porto Rico. 15(2) : 189-191, 1931.

The author gives the results of cross-inoculation experiments and of studies on the histology of leaves of various ages. The results of these later studies are, (1) When leaves are inoculated before the tissues are fully differentiated there is an inhibition of the development of cell structure and chloroplastic; (2) When chlorotic areas are formed on leaves with fully developed tissues there is no change in cell structure but the growth of the chloroplasts was inhibited; (3) That the enlargement of the mosaic areas on young leaves is due to cell division and growth and not to invasion of surrounding cells by the virus.

The leaf spots of tobaceo; an after symptom of mosaic. Journ. Dept. Agric. Porto Rico. 15(2) : 183-187, 1931.

This appears to be the same as the spot described by Mayer in 1886 and which Iwanowoski and Polowzoff described later as "pockenkrankheit". The author believes these spots to be a late symptom of tobacco mosaic.

New virus diseases of plants in Porto Rico. Journ. Dept. Agric. Porto Rico, 15(2) : 193-195, 1931.

This paper records mosaic on Adenoropium gossypifolium and Ipomoea nil.

The effect of mosaic on cell structure and chloroplasts. Journ. Dept. Agric. Porto Rico. 15(2) : 177-181, 1931. 
The author reports the result of studies of the effect of mosaic on the cell structure and chloroplasts of Capsicum annuum, Crotalaria striata, Carica papaya, Eucharis amazonica and a hybrid Amaryllis. The results confirm the author's previous opinion that the effect of many viruses is inhibitory.

Action inhibitrice du virus des mosiques sur l'évolution cellulaire. (Inhibitary action of mosaic virus in the cellular evolution.) Deuxiéme Congres international de Pathologie Comparće. p. 1-8, 1932.

This paper is a résumé of some of the work of the author published in "The Journal of the Department of Agriculture of Puerto Rico".

Virus diseases of plants. Sci. Monthly. 36(4):355-359, 1933. Popular.

\section{Cook, O[rator] F[uller]}

Leaf-cut or tomatosis, a disorder of cotton seedling. U.S.D. A. Circ. $120: 29-34,1913$.

This is a brief discussion of a disease which may be due to a virus.

Branchysm, a hereditary deformity of cotton and other plants. Journ. Agric. Res. 3: 387-399, 1915.

It has not been proved that this is a virus disease but it has many of the characteristics of this group of plant diseases.

A disorder of cotton plants in China: club-leaf or cyrtosis. Journ. Heredity 11 : 99-110, 1920.

A description of the disease with evidence that it is due to a virus.

Malformation of cotton plants in Haiti. A new disease named smalling or stenosis, causing abnormal growth and sterility. Journ. Heredity 14(7): 323-335, 1923.

The author describes a disease which he calls "smalling" or "stenosis". Certain characters resemble some of the virus diseases but it is neither contagious nor infectious.

Acromania or "crazy-top" a growth disorder of cotton. Journ. Agric. Res. 28(8) : 803, 1924.

It is known that this disease is caused by a virus. The author describes the symptoms of this disease and also of brachysm, tomosis, hybosis, eytosis and stenosis. 


\section{Cooley, L. IM., \& Rankin, W[illiam] H[oward]}

Virus disease control experiments in black raspberry plantings in 1931. New York (Geneva) Agric. Expt. Sta. Bull. 601: 3-6, 1931.

The results of the work. A brief report.

Mild streak of black raspberries. Phytopathology 22(11) : 905910, 1932.

A description of a disease which is believed to be due to a virus. The cause has not been proved.

\section{Coons, G[eorge] $\mathrm{H}$ [erbert]}

The potato disease of Michigan. Michigan Agric. Expt. Sta. Bull. 66, 31 p. 1914.

Popular paper describing diseases, including virus diseases.

Notes on plant diseases of Michigan. (Cucumber mosaic of white pickle.) Michigan Acad. Sci. 17:125-126, 1915.

Michigan potato diseases. Michigan Agric. Expt. Sta. Sp. Bull. 85, 49 p., 1918.

Popular descriptions with illustration and distribution in Michigan are given about the following diseases: Curly-dwarf, leaf-roll, and mosaic. Methods of control are also given.

\section{\& Kotila, J[ohn] E[rnest]}

Mosaic in potato seed stock. Michigan Agric. Expt. Sta. Quart. Bull. \&(4) : 135-138, 1922.

Popular.

Michigan potato diseases. Michigan Agric. Expt. Sta. Sp. Bull. 125 : 3-55, 1923.

Popular.

et al.

Sugar beet strains resistant to leaf spot and curly top. U.S.D.A. Yearbook 1931:493-496, 1931.

\section{Cooper, Thomas]}

Mosaic disease of potato and tobacco. Kentucky Agric. Expt. Sta. Ann. Rpt. 1922 (1) : 22-24, 37-38, 1922.

\section{Cordingley, H., Grainger, J., Pearsall. W. H., \& Wright, A.}

The effect of mosaic disease upon certain metabolic products in the tobacco plant. Ann. Appl. Biol. 21(1):79-89, 1934. Based on analysis, the authors found that a higher proportion of 
nitrogen than of earbohydrates was present in the tobacco plant infected with mosaic disease. In diseased leaves protein breakdown is retarded and insoluble substances are less readily hydrolysed. The diseased leaves resemble older leaves in their metabolism.

\section{Corneli, E.}

Mal del mosaico su Patate. Ruggine su Grano in autunno. Mal del piombo su Peschi. (Mosaic disease of potatoes. Rust of wheat in Autumn. Silver leaf of peaches.) Riv. Pat. Veg. 23(1-2) : 51-52, 1933.

Brief notes on the occurrence of mosaic disease of potatoes in Perugia (Italy). Deseription of the disease.

\section{Costa Lima, Angelo da}

A propósito de una comunicacao do Dr. Puttemans sobre a mosaico da cana de assucar. (About letter from Dr. Puttemans related to sugar cane mosaic disease. Characas e Quitaes $34: 30-42,1926$.

(Mosaic and thrips in Brazil) Bol. Agric. Ind. Comm. Brazil $2: 38-41,1926$.

The writer believes that Thrips minuta var Puttemansi is the vector for mosaic of sugar cane.

\section{Costantin, Julien [Noel]}

La dégenérence des plantes cultivées et l'hérédité des caractéres acquis. (The degeneration of cultivated plants and the inheritance of acquired characteristics.) Ann. Soc. Nat. Bot. 4 : 267-297, 1922.

Cure d'altitude, (Altitude cure) Ann. Sci. Nat. Bot. ser. 10, $6: 271-283,1924$.

A propos des mutations de la pomme de terre. (Concerning mutations in the potato.) Ann. Sci. Nat. Bot. ser. X, 6(5-6) : 17-40, 1924.

Un nouvel essai sur les Pommes de terre montagnardes. (A new test on highland potatoes.) Ann. Sci. Nat. Bot. 8(3-6) : 355-362, 1926.

Un programme pour la lutte contre la dégénérescence des Pommes de terre. (A program for the fight against the degeneration of potato.) Ann. Sci. Nat. Bot. 9(1):281-284, 1927. 
La cure d'altitude, son emploi et son efficacité en vegetalé. Essai d'une théorie de ce phénoméne. (Altitude is used successfully as a cure in plant pathology. Essay of theory on that phenomenon.) Ann. Sci. Nat. Bot. 9(2) : 299-369, 1927.

L'emploi des hybrides javanier de la canne a sucre contre le Sereh et mosaique. (The use of javanese sugar cane hybrids against sereh and mosaic diseases. Rev. Bot. Appl. Agric. Col. 9(93) : 229-240, 1929.

A review of the work on hybrids for the purpose of obtaining canes that are resistant to sereh and mosaic.

Les certificats phytopathologique de non-dégénérescence de la pomme de terre dans l'Amérique du Nord. (Phytopathological certificates attesting the freedom of potatoes from degeneration diseases in North America.) Comp. Rendus Acad. des Sci. 14: 534-536, 1930.

The author gives a brief note of the results obtained in United States and Canada in controlling potato virus diseases.

Influence de L' Altitude en Pathologie Végétale. (Influence of altitude in plant pathology.) Rev. Bot. Appl. \& Agric. Trop. 10(3) : 851-860, 1930.

\section{\& Lebard, P[aul]}

Cultures experimentales de la pommes de terre dégínérées et saines en montagne et en plaine. (Experimental eultures of degerated and healthy potatoes in the mountain and in the plain. Acad. d'Agric. de France 16(30):1006-1010, 1930. (Compt. Rend. Acad. Sci. 191(22) : 1038-1041, 1930.)

After experimentation the authors conclude that the favorable influence of the climate at high altitude can not operate unless rigid selection is practiced.

Accroisement de la résistance á la maladie par l'altitude. (In. crease of resistance to the disease with the altitude.) Journ. Agric. Prac. 1(39) : 249-250, 1930.

Review of the observations of the behavior of different types of virus diseases and different host plants, to altitude.

Hérédité montagnarde acquise a la canne á sucre. Mountain heredity acquired by the sugar cane.) Comp. Rendus Acad. des Sci. 195(5) : 345-347, 1932. 
This paper summarizes the studies on resistance to degeneration diseases acquired by mountain-grown canes and calls attention to a correlation with morphological characters.

Importance de la mosaïque de la canne au point de vue de la dégénérescence. (Importance of cane mosaic under the point of view of degeneration.) Comp. Rend. Sci. (Paris) 194(19): 1614-1616, 1932.

Resistance to mosaic has been increased in Java by growing erops on mountain elevation.

La mosaïque de la canne á sucre. (Enseignements découlant de sa récente histoire.) (Sugar cane mosaic. What its recent history has taught us.) Agron. Col. 21(176) : 41-51, 1932.

A general review of the subject. He believes that the reduction in mosaic in POJ varieties is due to this mountain origin.

Technique de la lutte contre les maladies de dégénéréscence Perfectionnements importance pour l'agronomical coloniale. Agric. Prat. Pays Chauds 3(22) : 241-250, (23) : 321-336, 1932.

Diseased and healthy potatoes were planted. Healthy potatoes gave higher yields than the diseased and the diseased potatoes in high altitudes gave higher yields than in the lower elevation.

Les curieux cas de variétés mosáiquées á cent pour cent. (Cucious case of mosaic varieties $100 \%$.) Compt. Rend. Acad. Agr. de France. 18(34) : 1149-1155, 1932.

Mention of sugar cane and potato mosaic.

Röle des montagnes en agriculture. (The role of mountains in agriculture.) Rev. Agric. France. 64(12) : 350-354, 1932.

Le secret de Java. (The Java secret) Compt. Rend. Acad. Sci. Paris 195(19): 741-744, 1932.

In this article the author refers to the success obtained in Java breeding cane seedlings at high altitudes to prevent sereh disease. He claims it, as a prove to cure of the "altitude" for certain diseases.

et al.

Experiences sur la cure en montagne de la pomme de terre. (Experiences on the mountain cure of the potato.) Ann. Sci. Natur. Bot. 14(2) : 327-341, 1932. 
Variations de la virulence dans les dégénérescence de pomme de terre. (Variations in virulence in the degeneration of potatoes.) Compt. Rend. Acad. Sci. 196(17) :1186-1189, 1933.

General account on virus diseases virulence especially on the potato.

L' immunité de la canne P. O. J. 2878 est-elle absolue? (Is the immunity of the cane P. O. J. 2878 absolute?) Compt. Rend. Acad. Sci. 196(18) : 1261-1264, 1933.

This article refers to the immunity of P. O. J. 2878 eane to sereh disease.

Résumé historique se rapportant á la genése des conceptions sur la dégénérescence des plantes cultivées. (Historical summary about the origin of the conception of the degeneracy of cultivated plants.) Compt. Rend. Acad. Sci. 196(7) : 449-451, 1933.

\section{Cottier, W.}

The transmission of virus disease of the potato by insects leafroll. New Zealand Journ. of Sci. and Tech. 13(2) : 85-95, 1932.

Experiments were conducted which demonstrated that leaf-roll of potato was transmitted by Myzus persicae, but not by $M$. pseudosolani, Macrosipium gei, Erythroneura Zealandica, Thrips tabaci or Melanphthalma gibbosa. The shortest period of incubation in the plant was 29 and the longest 51 days.

\section{Cotton, $\mathbf{A}[$ rthur] $\mathbf{D}$ [isbrowe]}

Mosaic disease of potatoes. Journ. Ministry Agric. Great Britain 28: 335-340, 1921.

Mosaic disease of potatoes. Gard. Chron. 70:131, 1921. Popular.

The situation with regard to leaf-curl and mosaic in Britain.

Roy. Hort. Soc. Inter. Potato Conf. Rpt. 1921 : 152-166, 1922.

Confirms work of Dutch and American students. Discusses suscepti. bility, environment and insects.

Potato leaf-eurl demonstration. Journ. Ministry Agric. (Great Britain) 28(11) : 1019-1021, 1922. 
Diseases in cane. Further notes on the subject of eane diseases, mosaic. Queensland Br. of Sugar Expt. Sta. Director's Rpt. 24th Ann. Rpt. p. 54-57, 1924.

Sugar pests and diseases in the Mackey District. Queensland Agric. Journ. 21(5) : 363-368, 1924 (Rev. Appl. Mycol. 3: 686-687, 1924.)

Reports sugar-cane mosaic. Aphis maidis not reported in list of sucking insects.

Sugar cane diseases in the South. Australian Sugar Journ. 16 : 596-597, 604-605, 1924.

The detection and control of lily diseases. Lily Yearbook, Roy. Hort. Soc. 1933. (Roy. Hort. Soc. (London) p. 194210, 1933.)

The author describes mosaic disease which occurred in the following species of lilies: Lilium longiflorum, L. trigrinum, L. humboldtii, and $L$. croceum; in these species the disease appears in a mild form, while in $L$. auratum, $L$. speciosum and $L$. caudidum is much more severe. Aphis gossypii the insect vector is abundant. Control measures are given.

Cottrell-Dormer, W.

Iliau disease of sugar cane. Australian Sugar Journ. 16: 838, 1925 .

Diseases of sugar cane. Australian Sugar Journ. 16:543, 545$546,1924$.

Cane pests and diseases. Queensland Agric. Journ. 22(4): 275-277, 1924. (The Cent. Sugar Journ. 16(12):833-835, 1924. Rev. Appl. Mycol. 4:242, 1924.)

Contains brief reference.

Cane diseases and pests. Queensland Agric. Journ. 23(1): 66-68, (4)271-272, 1925. (Rev. Appl. Mycol. 4: 267-268, 1925. Rev. Appl. Ento. ser. A. 13 : 348 1925.)

Brief reference on mosaic of sugar cane.

Report to the Director of the Bureau of Sugar Experiment Stations on mosaic disease in Mackay Areas. Australian 
Sugar Journ. 18(1) : 53-54, 1926. (Queensland Agric. Journ. 25(4) : 316-319, 1926. Rev. Appl. Mycol. 5:632, 1926.)

Mosaic has increased 300 per cent in two years. Recommends that corn and sorghum should not be grown near cane. Gives list of susceptibility hosts. Also recommends removal of Panicum colonum, $\boldsymbol{P}$. sanguinale and Setaria aurea. Aphis maidis was plentiful on $\boldsymbol{P}$. colonum.

Sugar cane pests in the district of Proserpine and Mackay. Queensland Agric. Journ. 25(4) : 312-319, 1926. (Rev. Appl. Ent. ser. A. $14: 365-366,1926$ )

\& Wood, E. J. Ferguson.

Fiji disease situation in Queensland. Queensland Agric. Journ. 28(2) : 125-141, 1927.

A general discussion of the disease with special reference to the situation in Queensland.

\section{Cottrell, R[oy] H[udson]}

Résumé of the relation of eurly-top to commercial sugar beet production. Utah Agric. Expt. Sta. Misc. Pub. No. 3, 1927.

\section{Cowdry, E[dmund] V[icent]}

The nature and significance of cellular inclusion bodies in diseases due to filterable viruses. Journ. Bact. 13(1) : 20-21, 1927.

The micro-chemistry of nuclear inclusions in virus diseases. Sci. $68: 40-41,1928$.

This paper has reference to virus diseases of animals but the method is of some interest to plant pathologists.

Cowgill, H[orace] $\mathrm{B}$ [ranson]

Report of the Plant Breeder. Porto Rico Ins. Expt. Sta. Ann. Rpt. 1917-1918, p. 78-104, 1918.

\section{Crawford, $\mathbf{R}$ [aymond] $\mathbf{F}$ [rank]}

Over-wintering of mosaic on species of Physalis. Phytopathology (Abstract) 11(1): 47, 1921.

\section{Crawley, J[osiah] T[homas]}

Control of the mosaic disease in Cuba. Facts About Sugar $22: 554-555$, 1927. (Rev. Appl. Mycol. 6: 752, 1927.)

Gives results of roguing and seed selection. 


\section{Cross, W[illiam] E[rnest]}

The Kavangeric cane. Louisiana Planter \& Sugar Manuf. 63: 397-399, 1919.

Kavangerie proved to be immune. The author also gives a discussion of its desirable and undesirable qualities.

Las posibilidades de las cañas de Java en Louisiana. (The possibilities of the Java canes in Louisiana.) Rev. Indus. Agric. Tucumán. 11: 118-121, 1921.

La Estación Experimental Agrícola de Tucumán. Su contribución a la Industria Azucarera de Puerto Rico.) The Agricultural Experiment Station at Tucumán. Its contribution to the Sugar Industry of Porto Rico.) Rev. Indus. Agric. Tucumán 13(11-12) : 207-211, 1923.

A controversy.

\section{\& Fawcett, G[eorge] L[orenzo]}

La enfermedad del mosaico en Luisiana. (The mosaic disease in Louisiana.) La Industria Azucarera. Argentina 30 (376) : 975-979, 1924.

Cañas resistentes al mosaico en Tucumán. (Canes resistant to mosaic at Tucumán.) Industria Azucarera, Argentina 30 (370) : 660-661, 1924. (Louisiana Planter \& Sugar Manuf. 73 : 468-469, 1924. Facts About Sugar 19(11) : 250-251, 1924.) Int. Sugar Journ. 27:551, 1925.)

Popular. Deterioration of certain varieties believed to be due to mosaic. Controversy.

La importancia de la enfermedad del mosaico en Louisiana y las posibilidades de éxito de las "Cañas de Java" en ese país. (The importance of mosaic disease in Louisiana and the possibilities of success of the "Java canes" in that country.) Rev. Indus. Agric. Tucumán 15(1-2): 22-28, 1924. (Rev. Appl. Mycol. 4:123-124, 1925.)

A very general discussion of conditions in Louisiana.

The problem of sugar cane yield in Louisiana. Facts About Sugar 18:442-443; 19 : 181-185, 442, 1924.

A comparison of mosaic conditions in Louisiana and Tucumán. 
THE JOURNAL OF AGRICULTURE OF THE UNIVERSITY OF P. R.

El mosaico de la eaña en Cuba. (Sugar cane mosaic in Cuba.)

Rev. Agric. Com. \& Trab. Cuba 7(4):9-10, 1924. Popular.

The problem of disease and other sugar cane yield factors in

Louisiana. Facts About Sugar 18:442-443, 1924.

Contains a brief note on mosaic.

Present needs in cane disease control. A rejoinder to Mr. A. H. Lee. Int. Sugar Journ. $27: 26-31,1925$.

Enfermedades de la caña de azúcar en Tucumán. (Sugar cane diseases in Tucumán.) Sugar 27(2):103-104, 1925.

La importación de la caña Kavangire en Puerto Rico. (Kavangire cane importation into Porto Rico.) El Mundo Azucarero 14(5) : 145-149, 1926. (Planter \& Sugar Manuf. 77 : 327330,1926 .)

Controversial.

The P.O.J.-979 variety in Tucumán. The Planter \& Sugar Manuf. 78(1): 8, 1927.

The P. O. J. eanes in Louisiana. Facts About Sugar 22:1230 1231, 1235, 1927.

Cruz, Francisco B., \& Bruner, S[tephen] C[ole]

Una visita de inspección a la Zona de tabaco en Cabaiguan. (An inspection of the tobacco region of Cabaiguan.) Rev. Agric. Comercio y Trab. Cuba 13(10) : 34-38, 1931.

A variety known as Puerto Rico which is probably Nicotiana lanceolata is very susceptible to mosaic. A small planting of $N$. hava nensis was almost free from the disease.

Cunningham, G[ilbert] C[ameron]

Report of the Dominion Field Laboratory of Plant Pathology, Fredericton, N. B. Canada Expt. Farms, Div. Bot. Interim Rpt. 1921: 57-67, 1921.

Report of Dominion Field Laboratory of Plant Pathology, Fredericton, N. B. Canada Expt. Farms, Div. Bot. Interim Rpt. 1921-22 : 23-30, 1922. 


\section{Curtiss, C[harles] F[ranklin]}

Plant Pathology studies and Entomology work in Iowa Agricultural Experiment Station. Iowa Agric. Expt. Sta. Ann. Rpt. 1922 : 24-35, 39-43, 1922.

Mosaic diseases of cucumber and other plants. Iowa Agric. Expt. Sta. Ann. Rpt. 1923: 39-40, 1923.

First record for Iowa of several plants affected with mosaic diseases.

\section{Curzi, IM[ario]}

Malattie del pesco caratterizzate de filliscosi ("Phony disease" e "malattie del pennacchio") Boll. Staz, Patol. Veget.) Firenze 11(3): 221-243, 1931.

Su una clorosi maculata della rosa. (A chlorotic spot of rose.)

Bull. R. Staz. Patol. Veg. 12(4) : 365-376, 1932.

Description of a chlorosis on roses. The disease is supposed to be due to the varietal sensibility to soil alkalinity.

\section{Cuthbertson, D[avid] C[unninghame]}

The relation of leaf and other diseases of the potato to the crop. Journ. Roy. Hort. Soc. 50(1) : 21-27, 1925.

Cutler, G[arner] H[omer,] \& Sandford, G[uthierie] B[rown]

Potato Diseases. Alberta Univ. Col. Agric. Field Husb. Cire. 7, 23 p., 1921.

Dade, H. A.

Cassava mosaic. Gold Coast Dept. of Agric. Year book 1930. Bull. 23 : 245-247, 1931.

The disease was observed on Manihot apii in 1926. It is spreading rapidly and the outlook is serious.

\section{Dafert, F[ranz] W[ilhelm]}

Bercht uber staatliche Massnahmen anlasslich des Anftretens und der Verbreitung der Blattrollkrankheit der Kartoffel in den Jahren 1908, bis 1910. (Mitteilugen des Komitees zum Studium der Blattroll-krankheit der Kartoffel, No. 1.) Zeitschrift fur das Land-wirtschaftlich Versuchsweseen in Oesierreich, Jahrg. 14(5) : 757-758, 1911.

\section{Dale, H. H.}

Introducing a discussion on the biological nature of the viruses. Brit. Ass'n. Adv. Sci. Centenary Meeting, London, Section 1, Physiology, 10 p., 1931. (Nature 128(3232) : 599-602, 1931. Agric. \& Live Stock, India 2(1):66-73, 1932.)

This paper is devoted to an effort to define virus. 


\section{Damf. A[lfonse]}

Bibliografía de los principales trabajos relativos al mosaico de la caña de azúcar que se han publicado a partir del descubri.miento de la enfermedad hasta el año 1929. (Bibliography of the leading articles related to sugar cane mosaic published from the discovery of the disease to the year 1929.) Boletín Mensual (Mexico) Oficina Federal para la Defensa Agrícola 3(5-8) : 186-236, 1929.

\section{Dana, B[liss] F.}

Mosaic and related diseases of potato and other crops. Washington Agric. Expt. Sta. Bull. 208: 33-34, 1926.

Brief notes on experimental work conducted during the year in regard to virus diseases.

Diseases of vegetable and field crops (other than cereals) in the United States in 1928. U.S.D.A. Plant Disease Reporter Suppl. $68:$ 15-109, 1929.

Mention of mosaic and curly-top of muskmelon, pumpkin, squash, and watermelon, ringspot of muskmelon, and yellows of lettuce.

Some experiments with mechanical transmission of the curly top virus. Phytopathology (Abstract) 22(12) : 997-998, 1932. The author used Seín's method with varying results.

Curly top of vegetable investigations. Oregon State Hort. Soc. Ann. Rpt. 24:81-84, 1932.

A summary of our knowledge of the virus diseases of sugar beets, tomatoes, beans, pumpkins and squashes.

The curly-top disease of vegetables in the Pacific Northwest. Oregon Agric. Exp. Sta. Circ. Inf. 67, 4 p., 1932.

\section{\& IMcWhorter, F. P.}

Mosaic disease of horse-radish. Phytopathology (Abstract) 22 (12) : 1000-1001, 1932.

Reports this disease which causes a dwarfing and yellowing.

\section{Daniel, L.}

Recherches sur la greffe des Solanum. (Researches on the grafting of the Solanum.) Comp. Rendus Acad. Sci. p., 1075, Nov. 29,1920 . 


\section{Darlington, $\mathrm{H}$ [aywars] $\mathbf{R}$ [adcliffle]}

Yellow stripe of daffodils. Journ. Roy. Soc. (London.) 34:161166, 1908.

\section{Darnell-Smith, G[eorge] P [ercy]}

"Bunchy top" in banana. Agric. Gaz. New South Wales 31: 583-584, 1920.

Gives description of the disease and recommends the destroying of the diseased plants. Reports the isolation of bacteria and a Fusarium.

Bunchy top in bananas. Trop. Agric. (Ceylon) 55(6) : 380-381, 1920.

Suspicion of the occurrence of bunchy top on bananas, and recommendations are made regarding measures of control.

Bunchy top in bananas. Agric. Gaz. N. S. Wales 34(12): 846, 1923.)

A brief note written before the cause was known.

\section{\& Tryon, $\mathrm{H}$.}

Banana bunchy-top disease. Queensland Agricultural Journ. $19: 33,1923$.

Bunchy top disease in bananas. Queensland Agric. Journ. $21(3)$ : 169-179, 1924.

A discussion of symptoms and possible causes.

\section{Dastur, J[ehangir] F[ardunji]}

The mosaic disease of sugar cane in India. Agric. Journ. oft. India. 18(5) : 505-509. (Rev. Appl. Ent. ser. A. 11:543, 1923.)

A record of resistant varieties.

A mosaic-like disease of sugar cane in the central provinces in 1926. Agric. Journ. of India. 21(6) : 429-432. (Rev. Appl. Ent. ser. A. 15:127. Rev. Appl. Mycol. 6:186, 1926.)

Report of a disease different from but similar to mosaic.

Sugar cane mosaic. Fourth Congress Intern. Soc. Sugar Cane Technologists Puerto Rico, 1932, Bull. 24, 4 p., 1933.

General account of sugar-cane mosaic disease as to its history, nature and behavior. 
108. THE JOURNAL OF AGRICULTURE OF THE UNIVERSITY OF P. $R$.

Davidson, W. D.

A review of literature dealing with the degeneration of varieties of the potato. Econ. Prov. Roy. Dublin Soc. 2(21-22): 331-389, 1928.

The rejuvenation of the champion potato. Econ. Prov. Roy. Dublin Soc. 2(21) : 319-330, 1928.

\section{Davis, Everett F[ogg]}

Some chemical and physiological studies on the nature and transmission of "infectious chlorosis" in variegated plants. Ann. Missouri Bot. Garden 16(2) : 145-213, 1929.

The author gives the results of extensive studies on Euonymous and Abutilon. He could not confirm the studies of Baur concerning the effects of light.

Davis, E. W.

Notes on collection of the sugar beet leafhopper showing the extension of its known range into British Colombia and to the coast in Washington and Oregon (Eutettix tenella.) Journ. Econ. Ent. 20 : 581-586, 1927.

This paper gives some data on the range of this insect which is the carrier of the virus of the curly-top of sugar beet.

\section{Davis, J[ohn] J[une]}

Biological studies on three species of Aphididae. U. S. Dept. Agric. Bur. Ent. Tech. ser. Bull. 12:123-168, 1909.

Virus and life. Nature 125(3149): 351, 1930.

A controversial note.

\section{Davis, $R$ [obert] L[esley]}

Java-Barbados hybrids in Porto Rico. Planter \& Sugar Mafg. 83(5) 83-85, 100 (6) : 103-104; (7) : 123-125, 1929. (Rev. Appl. Mycol. 9(2) : 132, (1930).

Mayagüez 3, 7 and 42-Three cane varieties immune to mosaic. Porto Rico Agric. Expt. Sta. Agric. Notes No. 52, 2 p. (Mimeograph.) 1930.

The three varieties Mayagüez 3, 7 and 42 produced from crossing POJ-2725 and SC-12(4) appeared to be resistant to mosaic.

Report of the Plant Breeder. Porto Rico Agric. Expt. Sta. Rpt. 1931 : 13-22, 1932.

Includes a report on some sugar canes commercially resistant to mosaic. 
Mayagüez 28, 49 and 63, three sugar cane varieties commercially resistant to mosaic. Agric. Notes, Porto Rico Agric. Expt. Sta. Mayagüez 61, 6 p., 1932.

A report on the behavior of these and other varieties.

Sugar cane crosses with Kassoer selfs. Trans. Fourth Intern. Soc. Sugar Cane Tech. 1932. (Facts About Sugar (Abstract.) $27(5): 218,1932$.

Tests with erosses of Kassoer as to susceptibility to mosaic disease of sugar eane.

Sugar cane seedling mosaic elimination. Trans. Fourth Congr. Intern. Soc. Sugar Cane Tech. 1932. (Facts About Sugar (Abstract) 27(5): 219, 1932.

Experiments to determine the optimum spacing and planting methods for obtaining data on the reaction of sugar-cane seedling to mosaic. Under Mayagüez (Puerto Rico) conditions, it was found that mosaic will spread in 8 months for a distance of 50 feot along a single row of a susceptible variety.

Report of plant breeder. Porto Rico Agric. Expt. Sta. Ann. Rpt. 1932 : 11-17, 1933.

Report of the work done during the year with mosaic-resistant seedlings.

\section{Davis, W[illiam] $\mathrm{H}$ [arold]}

Chlorotic corn. Proc. Iowa Acad. Sci. 24:459-460, 1917.

\section{Decoux, L.}

La frisolée de la betterave sucriere. (The curling of the sugar beet.) La Sucriere Belge 44:177-185, 1924.

A description of the symptoms of the disease and a discussion of quarantines.

\section{Deerr, Noel}

The yellow stripe cane disease. Facts About Sugar 10(10): 190-191; (11) : 210-211: (12) : 232-233, 1920.

Deighton, F. C.

Report of the Mycological Section. Ann. Rpt. Lands and Forests Dept. Sierra Leone for the 1928: 14-19, 1929. (Rev. Appl. Mycol. 9(1) : 18-20, 1930.)

Contains reference to mosaic of Manihot glaziovii and rosette of peanuts. 
Mycological work. Sierra Leona Dept. Agric. Ann. Rpt. 1931: 20-25, 1932.

Report on virus disease of cassava, Locheria rosea and Sesamum radiatum.

\section{Delacroix, Edward G[eorges]}

La Vouille Blanche du Tabac et la nielle ou maladie de la mosaique. (The "Vouille Blanche" of tobacco and the "Nielle" or mosaic disease.) Compt. Rendue 140:678-680, 1905. (Rev. Zeithschrf. f. Pflanzenkh, 16:239, 1906.)

The disease "la nielle" reported by Prillieux and Delacroix 1894, was not true mosaic but a bacterial disease (Vouille blanche). Believes the "pockenkrankheit" of Iwanowski and "spotting" of Sturgis may be the same as Vouille blanche.

Recherches sur quelques maladies des Tabac en France. (Investigations of some tobacco diseases in France.) Ann. Inst. Nat. Agron. Paris. 2 Ser., 5: 92, 1905. (Rev. Centr. Bakt. $20: 193,1905$.

\section{De Long, D[wight] M[oore]}

The occurrence of the beet leafhopper, Eutettix tenella Baker, in the Eastern U. S. Journ. Econ. Ent. 18: 637-638, 1925.

An entomological record.

\section{Delplace, E.}

Essais de sélection en vue de parer la dégénérescence des pommes de terre faits en Loir-et-Cher de 1924 á 1928. (Tests of selection made in Loir-et-Cher in 1924 to 1928 with the view to guard against the potato degeneration.) Bull. Mens. Soc. Nat. Hort. France 5(2) : 287-289, 1929.

A popular paper suggesting methods of contrel.

\section{Demarre, J. B.}

Progress of pecan rosette control. Proc. 27th. Ann. Convent. Georgia-Florida Pecan Growers' Assoc. p. 38, 40, 42-43, 45, 1933. (Chem. Abstract 27(22):5880, 1933.

The author reports his success controlling pecan rosette with applications of zine sulphate to the soil or placed in holes in the trunks of the trees.

\section{Detmers, F[rederika]}

Diseases of the blackberry and raspberry. Ohio Agric. Expt. Sta. Rpt. 4:128-129, 1891. 
Diseases of blackberry and raspberry. Conn. Agric. Expt. Sta. Rpt. $1903: 4-5,1903$.

\section{Dey $\mathbf{P}$ [romode] K[umar]}

A note on the control of sugar cane mosaic in the eastern districts. Bull. Dept. Agric. U. Prov. Agric. \& Ondh. Bull. 46: 7, 1929.

\section{Dickson, B[ertram] T[homas]}

Some plant diseases in the greenhouse. Quebec. Soc. Protec. of Plants. Ann. Rpt. $12:$ 46-48, 1920.

A mosaic-like disease of Cineraria. Quebec Soc. Prot. of Plants. Ann. Rpt. 46-47, 1920.

Diseases of the potato: mosaic and mosaic dwarf. Sci. Ayric. $2: 93-96,1921$.

Studies on mosaic. Phytopathology (Abstract) 11(4):202, 1921.

Plant diseases of 1920-21. Quebec Soc. Prot. of Plants. Ann. Rpt. 13: 66-67, 1921.

Studies concerning mosaic diseases. Me Donald College (Quebec) Tech. Bull. 2, 125 p., 1922.

A very lengthy discussion giving symptoms of several mosaic diseases, histological studies, effects of light and methods of transmission.

\section{\& MIcRostie, A[ordon] $\mathbf{P}$ [eter]}

Further studies on mosaic. Phytopathology (Abstract) 12(1) : 42, 1922.

Plant diseases of 1921 in Quebec. Quebec Soc. Prot. Plant, Ann. Rept. (1921-22) 14:52-58, 1922.

Further studies on mosaic. Phytopathology (Abstract) 12:16, 1922.

Further studies on mosaic 1. Phytopathology (Abstract) 12: 42, 1922. 
Raspberry mosaic and curl. Sci. Agric. 3(9) : 308-310, 1923. Gives brief history, symptoms, susceptibility and insect transmission.

Temperature studies in mosaic disease. Phytopathology (Abstract) $13(1): 42,1923$.

\& Hood, E. G.

Temperature studies in mosaic disease. Phytopathology (Abstract) $13(1): 42,1923$.

Studies in disease susceptibility. (Tobacco mosaic) Quebec Soc. Prot. Plant. Ann. Rpt. 1922-1923 : 15-60, 1923. (Sci. Agric. 3: 307, 1923.)

Mosaic studies IV. Phytopathology (Abstract.) 14(7):346, 1924.

Tobaceo and tomato mosaic. (1) Longevity of the virus of tobaceo mosaic. Science 62(1609): 298, 1925.

The juice from a mosaic tobacco plant kept in a sealed bottle for 5 years retained its vitality. The symptoms of tomato streak or stripe resulted from an inoculation with a mixture of potato and tomato mosaic juices.

Mosaic of rhubarb. Quebec Soc. Prot. Plants. Ann. Rpt. 1924-25. $17: 36-37,1925$.

A record of mottling and dwarfing. Inoculation experiments gave negative results.

Virus diseases. Quebec Soc Prot. of Plants, Ann. Rpt. (1925

26) $18: 10-13,1926$.

Popular.

\section{Dickson, Thomas}

Observations on the disease in the potato generally called the curl; pointing out the most probable method of prevention; with account of the result of a few experiments made on the subject. Memoir, Caledonia Hort. Soc. 5:49-59, 18 p. 1814 (Abstract in Stephens Book of the Farm 5:203, 1847.) 


\section{Dijk, J. van}

Verband tusschen shjmisierkte en mozaikziekte. (Relation between gumosis and mosaic.) Meded. Deli Proest. Medan, 2, ser., No. 11, p. 13-15, 1930.

\section{Dijk, M. D.}

Inloed van den rootijd van aardappels op het optreden van degeneratis-ziekten in den natelted (Influence of potato harvest time on the occurrence of degeneration diseases in the progeny.) Landb. Tijdschr. 36:209-223, 1924.

A discussion of the susceptibility with reference to races and environments.

\section{Dix, W[alter]}

(Leafroll of potato.) Fuhling's Landw. Ztg. 62(6) : 214-222, 1913.

\section{Dobroscky, I[rene] D[orothy]}

Is the aster yellows virus detectable in its insect vector? Phytopathology 19(11): 1009-1015, 1929.

This paper gives a record of studies in which the results were negative.

Cranberry false-blossom disease spread by a leafhopper. Science $70(1826)$ : 635, 1929.

Studies over a period of three years show that Euscelis striatulus is able to transmit the virus.

Morphological and cytological studies on the salivary glands and alimentary tract of Cicodula sexnotata (Fallen) the carrier of aster yellows virus. Contrib. Boyc. Thompson Inst. 3(1) : 39-58, 1931.

Studies on cranberry false blossom diseases and its insect vectors. Contr. Boyce Thompson Inst. 3(1) : 59-83, 1931.

A study of the salivary glands and alimentary canal did not show any difference between healthy, and disease carrying insects.

\section{Dobrosky, I. B.}

Insect studies in relation to cranberry false blossom disease. Amer. Canberry Growers' Ass'n. Prot. Ann. Meetg. 58:6-7, 10-11, 1928.

Popular.

\section{Dobrosky, T. L.}

(Non parasitic diseases of the potato.) Morbi Plantarum Leningrad 16(2): 121-135, 1927. 
114 THE JOURNAL OF AGRICULTURE OF THE UNIVERSITY OF P. R.

\section{Doby, G[éza] K[arl] von}

Biochemische untersuchungen uber die Blattrollkrankheit der Kartoffel. (Biological studies on potato leafroll disease.) Zeitsch. fur Pflanzenk, 20:401-403, 21(1/2):10-17, (16) : 321$336 ; 22(4): 204-211 ;(7): 401,403,1912$.

Die Amylase bei den gesunden und bei den von der Blattroll. krankheit befallenen Kartoffelknollen. Kiserletügyi Közlemenyek 19: 956-968, 1915.

\section{\& Bodnár, János}

Biochemische Untersuchungen über die Blattrollkrankheit der Kartoffel. V. Die Amylase blattrollkranker Knollen. (Biochemical investigations on the leaf-roll disease of potato. V. The amylase in leaf roll diseased tubers.) Zeitschr. Pflanzen krankh. 25:4-16, 1915.

Dodds, H. H.

Menace of streak disease. South African Sugar Journal. 9: 549, 1924.

South African Sugar Association Experiment Station. South Afr. Sugar Journ. 9:311-313, 1925.

A comparative study of streak diseased and healthy cane. The author gives the result of experiments for the control of insects and the use of fertilizer for the control of the disease.

Memorandum on methods of controlling streak diseases. South Afr. Sugar Journ. 9(5): 337, 1925.

Streak diseases in Mauritius. Disease Proved Similar to Natal. South Afr. Sugar Journ. 9:583, 1925.

Treatment of streak disease: South Afr. Sugar Journ. 9(9): 593-599, 1925.

Acquired Resistance of POJ-213 to mosaic. South Afr. Sugar Journ. 12(10) : 627-629, 1928.

Fongaat group members visit the Experiment Station. Afr. Sugar Journ. 14(4) : 265, 267, 269, 1930.

Streak disease of sugar-cane immunity in POJ-2714 and POJ-2725. 


\section{\& Fowlie, $\mathbf{P}$.}

Experiments to test the effects of streak disease of Uba cane. South Afr. Sugar Journ. 16(4):231-233, 1932.

Description of experiments and results obtained.

The origin of mosaic disease. South African Sugar Journ. 16(11) : 617, 619, 1932.

The information given in this article is the result of data gathered by the author while visiting Puerto Rico to attend the International Congress of the Association of the Sugar-Cane Technologists held on February, 1932. He refers here to the mosaic of sugar cane in Puerto Rico.

\section{\& Fowlie, P.}

Effect of streak disease on Uba cane. South African Sugar Tech. Ass'n. Vol. 8, 1934.

Popular notes in regard to spread of the disease. Recommends to plant Co. 281, P. O.J. 2878, 2727 and 2714 canes to replace Uba on account of their resistance to streak.

\section{Dodge, B[ernard] O[gilvie]}

Notes on cucurbit mosaic. Phytopathology (Abstract) 12:4243, 1922.

\section{Doolittle, S[ears] P[olydore]}

A new infectious mosaic disease of cucumber. Phytopathology, (Abstract) 6(2) : 145-147, 1916.

Gives a description and the results of successive inoculation experiments.

\section{\& Gilbert, W[illiam] Williams}

Further notes on cucumber mosaic disease. Phytopathology (Abstract) 8(2):77-78, 1918.

Seed transmission of cucurbit mosaic by the wild cucumber. Phytopathology (Abstract) 9(8) : 326-327, 1919.

Thirteen out of 110 plants grown from seed of wild cucumber (Micrampelis lobata) were diseased.

The mosaic disease of cucurbit. U.S.D.A. Dept. Bull. 879: 69 p., 1920.

Gives symptoms, pathological anatomy, history, nature, methods of transmission, overwintering and other valuable data.

The relation of wild host plants to the overwintering of cucurbit mosaic. Phytopathology (Abstract) 11(1):46-47, 1921. 
116 THE JOURNAL OF AGRICULTURE OF THE UNIVERSITY OF P. R.

\section{\& Walker, $\mathbb{M}[$ arion] $\mathbf{N}$ [ewman]}

Notes on cucurbit mosaic. Phytopathology (Abstract) 12(I): 42-43, 1922.

\section{\& McKinney, $\mathrm{H}$ [arold] $\mathrm{H}[\mathrm{all}]$}

Intracellular bodies in the phloem tissue of certain plants and their bearing on the mosaic problem. Phytopathology, 13 (7) : 326-329, 1923.

This paper gives the results of studies on the phloem tissue of mosaic and healthy plants. The authors describe protozoa-like bodies such as were described by Strasburger for Robinia pseudacacia.

\section{\& Walker, IM[arion] $\mathbf{N}$ [ewman]}

Cross-inoculation studies with cucurbit mosaic. Science n.s. 57 (1477) : 477, 1923.

This paper gives the results of cross inoculation studies.

The mosaic disease of melons and cucumber. Iowa State Hort. Soc. Rpt. 57 : 393-396, 1923.

Popular.

\section{Walker, $\mathrm{M}[$ [arion] $\mathrm{N}$ [ewman]}

Experiments of the control of cucurbit mosaic. Phytopathology (Abstract) 14(1): 56, 1924.

Control of the cucurbit mosaic in the greenhouse. U. S. D. A. Circ. 321, 5 p., 1924.

This paper gives general discussion of the disease with special attention to other host plants which earry the virus over winter.

\section{\& Walker, $\mathbf{M}[$ arion] $\mathbf{N}$ [ewman]}

Further studies on the overwintering and dissemination of cucurbit mosaic. Journ. Agric. Res. 31(1) : 1-55, 1925.

A very extensive paper giving results of cross inoculations and the study of transmission by insect vectors. Recommends removal of host plants in which the disease passes the winter.

\section{\& Jones, $\mathrm{F}[\mathrm{red}] \mathrm{R}[\mathrm{emel}]$}

The mosaic in the garden pea and other legumes. Phytopathology 15(12) : 763-771, 1925.

The disease occurs on Pisum sativum and Lathyrus odoratus. It ean be transferred to Trifolium pratenses in which it probably passes the winter.

\section{\& Walker, IM[arion] $\mathrm{N}$ [ewman]}

Control of cucumber mosaic by eradication of wild host plants. U.S. D. A. Bull. 1461:14 p., 1926. 
This paper gives the results of a number of experiments on methods of control, including studies of the disease on other plants and also studies on transmission by insects.

$\&$

Investigations of cucumber mosaic. Canner 63(18):25-27; (19) : 21-22, 1926.

Popular.

$\&$

Aphis transmission of cucumber mosaic. Phytopathology (Abstract) 18(1):143, 1928.

Soil transmission of tobacco mosaic and streak in the greenhouse. Phytopathology (Abstract) 18(1):155, 1928.

Greenhouse mosaic control. Wisconsin Hort. 20:61-62, 1929. Popular.

\section{\& Blood, H[erbert] L[oren]}

Investigation of tomato streak. Phytopathology (Abstract) $20(1): 134,1930$.

\section{\& Sumner, C[harles] B[uchanan]}

The occurrence of the Australian spotted wilt of tomatoes in Wisconsin. Phytopathology (Abstract) 21(1):106, 1931.

A virus disease appeared in Wisconsin similar to spotted wilt from Australia. It is readily transmissible to tomato by artificial inoculation.

Commelina nudiflora, a monocotyledonous host of celery mosaic. Phytopathology (Abstract) 21(1):114, 1931.

\section{\& Wellman, F. L.}

Commelina nudiflora, a monocotyledonous host of celery mosaic. in Florida. Phytopathology 24(1):48-61, 1934.

General discussion of the disease which has been observed during the past four years in Florida. The disease may be transmitted mechanically and by Aphis gossypii. Hosts are discussed. The virus does not appear to persist in the soil nor in the seed. Eradication of Commeline nudiflora is recommended as control for celery mosaic under Florida conditions.

\section{Dorst, J[acobus] C[ornelis]}

Overbrenging van mozaikziekte door beschadiging of aaraking van planten. Landbouwkd, Tijidschr. No. 509: 512-517, 1930. 


\section{Dosdall, Louise}

A mosaic disease of Gladiolus. Phytopathology 18(2):215-217, 1928.

A description of the disease with evidence that it is due to a virus.

\section{Doty, $\mathbf{R}$ [alph] $\mathbf{E}[\mathrm{are}]$}

A yellow stripe disease survey. H. S. P. A. Expt. Sta. Circ. 35, 71 p., 1920.

\section{Dover, C.}

Preliminary report of the sub-station using spike-disease of Sandal. (Santalum album Linn.) I. An introductory survey of the problem. Indian For. Rec. Calcutta $17(1): 1-53,1932$.

\section{Doyer, Lucie C[hristine]}

Iots over gozendheistvestand der zaaizden in verschillende jarem. (Notes on the state of health of seed material in different years.) Tijdschr, over Plantenzickten 34(4):65-74, 1930.

Popular discussion of bean mosaic.

Untersuchungen uber den Gesundheitsszuztand des Saatguts. (Investigations on the state of health of seed.) Comp. Rend. Assoc. Internat. d'Essais de Semences 13-13, p. 41, 1930 (English Summary.)

The author gives a scheme of classification of the various types of seed injuries, including infection by parasitic fungi and virus diseases. Important examples of each are discussed.

\section{Drake, C. J., Tate, H. D., \& Harris, H. IM.}

Preliminary experiments with Aphids as vectors of yellow dwarf. Iowa Sta. Coll. Journ. Sci. 63: 347-355, 1932.

A description of the methods. The vectors are bean aphid (Aphis rumicis), apple green aphid (Rhopalosiphium prunifoliae), green peach aphid (Myzus persicae), melon aphid (Aphis gosypii), potato aphid (Macrosiphum gei) and corn aphid (Aphis maidis).

Insects as vectors of yellow dwarf of onions. Science n.s. 75 (1943) : 341-342, 1932.

A report of recent studies on insect vectors. The disease has been transmitted by Aphis rumicis, A. maidis, Rhopalosiphium prunifoliae and Cicadula sexnotata.

\section{Harris, H. M., \& Tate, H. D.}

The relationship of aphids to the transmission of yellow dwarf of onions. Journ. Econ. Ent. 26(4) : 841-846, 1933. 
The authors found over 50 distinct species of aphids in Iowa. They found them capable of transmitting the disease during their first feeding on diseased plants and 3 or 4 days after the plant has been inoculated by the aphids it becomes a source of infection and harbours the virus. The aphid loses its virulence very quickly. A list is given of the species of aphids studied which are capable of acting as vectors of yellow dwarf in field and greenhouses.

\section{Dschounkowsky, E.}

Le "mosaïque" du tabac. (Tobacco mosaic.) XIV éme Congrés Intern. D’ Agric. R. 13(4) : 1-2, 1929.

\section{Duboys, C[harles]}

Project relatif á l'organisation départementale de la sélection de la Pomme de terre parles offices départamentaux de la région de l'Quest. (Projects in relation with the departamental organization of potato selection for the offices of the department of the west region.) Off. Agric. de l'Quest, 1921.

Quelques conseils sur la sélection de la Pomme de terre dans la lutte contre les maladies dites de dégénérescence. (Some advices on potato selection in the fight against the so-called degeneration disease.) Off. Agric. Rég. de l'Quest, 1921.

La sélection de la Pomme de terre en Hollande. (Potato selection in Holland.) Off. Agric. Rég. de l'Quest, 1921.

La lutte contre la dégénérescence des pomme de terre dans l'Ouest de la France. (The campaign against degeneration, of potatoes in the West of France.) Rev. Bot. Appl. 2(14): 586-589, 1922.

\section{Duchartre, $\mathbf{P}$.}

Innoculation de la panachure par la greffe; Exposé historique. (Inoculation of mottling by grafting; historical account.) Belgian Hort. $20: 113-118,1870$.

\section{Ducomet, V[ital]}

Station de physiologie et de pathologie des plantes cultivées. Semmis de Pomme de terre. (Physiology and pathology station for cultivated plants. Potato seeds.) Ann. Ec. Nat. Crignon 1920-21 : 114-142, 1921. 
De la dégénérescence des végétaux multipliés par vois asexuée. (The degeneration of the plants propagated by the asexual way.) Journ. Soc. Nat. d'Hort. France, Juillet, 1921.

Observations et expériences sur les maladies de dégénérescence, de la Pomme de terre. (Observations and experiments on degeneration diseases of the potato.) Bull. Soc. Path. Vég. France 9(1): 29-38, 1921.

Gives the results of studies at various altitudes. Seventy varieties were studied and none were free from degeneration diseases. Found the leaf-roll and curly-leaf on Solanum maglia, S. commersonii and $\mathbf{S}$. calcasii.

\section{\& Foex, $\mathbf{E}[$ dmond] $\mathbf{E}[$ tienne]}

Notes sur les maladies de la dégénérescence de la Pomme de terre. (Notes on the degeneration of potatoes.) Rev. Bot. Appl. et Agric. Col. 2 :325-330, 1922. (Min. Agric. Ann. Epiphyties 8: 27-93, 1922.)

The authors believe these diseases due to leaf-roll, mosaic and similar diseases.

Sur la visibilité des symptomes de la mosaïque de la Pomme de terre. (Visibility of potato mosaic symptoms.) Rpt. Int. Conf. Phytopath. \& Econ. Entom. p., 29-43, H. Veenman \& Sons. Wageningen, 1923.

A record of additional symptoms on mosaic plants.

Les principales maladies de la Pomme de terre. Les moyens de les prévenir. La selection. Conservation des tubercules. (The principal diseases of the potato: Means of preventing them, selection and preservation of the tuber.) Offs. Agric. p., 16, Libraire Agric. de la "Maison Rustique" Paris, 1923.

Dégénérescence de la Pomme de terre et degré de maturité du tubercule semence. (The degeneration of potatoes and the stage of maturity of the seed tuber.) Rev. Path. Vég. et Ent. Agric. 11(3) : 183-188, 1924.

Tubers that are harvested early produced plants with less leaf-roll than tubers that were harvested later.

Dégénérescence de la Pomme de terre. (Degeneration of the potato.) Ann. Econ. Nat. d'Agric. Grignon 1921-1922, 8 : 96-136, 1924. 
Les maladies de la Pomme de terre. Caractéres auxquels on les reconnait. Moyens de les combattre et de les prevenir. (Diseases of the potato. Characters by which to recognize them. How to control and prevent them.) Librairie de la "Maison Rustique", Paris 32 p., 1925.

Nouvelles observations sur la filosité de la Pomme de terre. (New observations on "Filosité" of potato.) Rev. Path. Veg. et Ent. Agric. 13:172-178, 1926.

This disease may be associated with leaf-roll or other virus diseases.

Maladies de dégénérescence de la Pomme de terre. Comptes Rendus Scéances Congrés Nationale pour la lutte contre les ennemies des Cultives, tenu á Lyon en juin 1926. (Degeneration diseases of the potato. Proceedings of the National Congress for the fight against the enemies of crops, held at Lyon on June 1926.) Sev. Agric. du P.L.M., 1927: 68-82 1927.

La mosaïque de la betterave. (Mosaic of sugar beet.) Rev. Path. Vég. et Ent. Agric. 15(1) : 24-29, 1928.

The author gives results in graphics and tables of an experiment with two lines of mosaic sugar beets. He reaches the conclusion that although the weight remained apparently the same in the yield there is a difference of 1 per cent in sugar content in favor of the healthy beets. 16 per cent compared to 17 per cent.

La filosité de la Pomme de terre, maladies á crises. ("Filosité") of the potato, an intermittent disease.) Rev. Path. Vég. et Ent. Agric. 15(7) : 184-185, 1928.

Continuation of previous experiments. In this case the author started with 15 tubers of the 1924 crop. Planting year after year lead to the conclusion of intermittency. Advises roguing for control.

La mosaïque de la Betterave et la selection. (Beet mosaic and selection.) Bull. Assoc. Intern. Selectionneurs de Plantes de Grande Cult. Gembloux 2(2):44-48, 1929. (Abstract in Resumption Genetica 4(5):242, 1930. Rev. Appl. Mycol. 9 (10) : 620, 1929.

These experiments have demonstrated the possibility of transmitting beet mosaic by seeds and by infection from Aphis. 


\section{Duffield, C[harles] W[illiam]}

Nettle-head in hops. Ann. Appl. Biol. 12(4) : 536, 1925.

This disease was supposed to be due to nematodes. Cause is doubt. ful as some characteristics are of a virus disease.

\section{Dufrénoy, Jean}

Les maladies de Pomme de terre dans les Haute-Pyrénées. (Diseases of the potato in the High Pyrenees.) Bull. Soc. Path. Vég. France. 8: 137-138, 1923.

La transmission des maladies des plantes par voie biologique. (The transmission of plant diseases by biological means.) Report of a paper read before the Société de Pathologie comparée on the 10th of April 1923, 9 p. (Rev. Gen. des Science $32(13): 389,1923$.

Le tabac blanc. (White tobaceo.) Ann. Epyphites 13:43-47, 1927.

La mosaïque de la canna de sucre. (Sugar cane mosaic.) Ann. Epyphites 14(1) : 25-36, (3) : 199-210, 1928.

Introduction á l'etude eytologique des plantes affectées par des maladies á virus. Ann. Epyphites 14(2) : 163-174, 1928.

The author studies the plastids and mitochondria of both fresh and fixed material of mosaic plants. The degeneration of the cell contents appeared to be analogous to that caused by certain physiochemical agents and to certain fungi and bacteria.

Les mosaïques du tabac. (Mosaic of tobaceo.) L'Off. Agric. Regional du Massif Centrale Bull. 9:3-11, 114-125, 1928.

Condition d'hypotomic des cellules affectées par la mosaïque. (Hypotomic conditions of cells affected by mosaic.) Compt. Rend. Soc. de Biol. 98: (17) :1499-1500, 1928. (Rev. Appl. Mycol. $7(10): 660,1928$.

The author found that epidermal tissue of leaf affected with mosaic disease showed vesicular alteration of the plastids and mitochon. dria. The staining of the vacuoles by neutral red is very irregular in the discolored areas. It was shown that cells of the mosaic tissue were in a marked hypotomic condition. 
Les vacuomedes cellules de Canne de sucre affecteés de mosaïque. (The vacuoles of the cells of sugar cane affected with mosaic.) Compt. Rend. Soc. Biol. 99 : 503-505, 1928.

Cytological studies of plant tissue affected with mosaic disease. Phytopathology (Abstract) 18(1):154, 1928.

Modifications des mitochondries et des planties dans less cellules des Haricots affectées de mosaïque. (Modifications of the mitochondria and the plastids within the cell of the leaves of beans affected with mosaic.) Compt. Rend. Soc. Biol. 98(5) : 373-374, 1928.

La mosaïque du blé, (Wheat mosaic.) Bol. R. Staz. Pat. Veg. Florenz, n.s. 9(3) : 298-304, 1929.

Discussion and description of the disease based on McKinney'm studies.

Changes induced in cells of sugar cane by mosaic. Proc. Pacific Sci. Cong. (Java) 4(4) : 25-27, 1929.

\section{\& Hédin, L[ouis]}

La mosaïque des feuilles du Monioc au Cameroun. (Mosaic of Cassava leaves in the Cameroons.) Rev. Bot. Appl. 9(94): 361-365, 1929. (Rev. Appl. Mycol, 9(1):11, 1930.)

The disease is severe in the Cameroons and in the greater part of West Africa.

Les maladies á virus aux États Unis. (Virus diseases in the United States.) Rev. Bot. Appl. et Agric. Trop. 9(9):685693, 1929.

Les maladies á virus chez les vegetaux. (Virus diseases of plants.) Rev. Path. Hyg. Gen. (366-367) : 1-18, 1929.

, \& Stamatinis, N., \& Srejanni, J.

Etudes cytologiques sur la mosaïque du tabac. (Cytological studies on tobacco mosaic.) Rev. Path. Vég. et Ent. Agric. 16(3) : 106-117, 1929.

This paper gives the results of studies on the mitochondria, striated and vacuolated bodies in cells of mosaic plants. 
Les recéntes études cytologiques relatives aux maladies á virus. (Recent eytological studies in regard to virus diseases.) Rev. Path. Comp. et Hyg. Gen. 5: 213, 229, 366-367, 1929.

La Canne á Sucre en Florida. (Sugar cane in Florida.) Rev. Bot. et Agric. Trop. 9: 34-38, 1929.

Études cytologiques relatives aux maladies á virus. (Cytological studies relating to virus diseases.) Phytopath. Zeitschr. 1(2) :151-167, 1929. (Rev. Appl. Mycol. 9(1) : 47, 1930.)

La mosaïque de la Canne á Sucre. (Sugar cane mosaic.) Ann. Epiphities 14(3): 199-210, 1929. (Rev. Appl. Mycol. 9(1) : 61, 62, 1930.

The disease causes a modification of the vacuolar system of the cells and appears to prevent the mitochondria from developing into chloroplasts.

Les taches du tabac. (The tobaceo spots.) Bull. Off. Agric. Massif, Central, $10:$ 121-123, 1929.

Leaf tissues may be killed by virus diseases developing white spots or ring spots. The living cells surrounding these spots show a degeneration of the chloroplasts, plastids and cytoplasm.

Étude cytologique des taches blanches du tabac. (Cytological study on the white spots of tobacco.) Rev. Path. Vég. Ent. Agric. 16(4-5) : 146-159, 1929.

The changes induced in the cytoplasmic structure of cells by virus diseases. Fifth Int. Bot. Congr. Cambridge, 1930 : 367$368,1930$.

Les maladies á virus chez les plantes. (Virus diseases of plants.) Rev. Gén. Sci. 41(8) : 237-243, 1930.

A discussion of the desintegration of the plastids. The starch is translocated and the plastids appear as vesiculated bodies.

Études cytologiques relatives aux maladies á virus. (Cytological studies in relation with virus diseases.) Phytopath. Ztschr. 2(1) : 151, 1930. 
Les maladies á virus au Congrés de Botanique de Cambridge. (The virus diseases in the Botanical Congress at Cambridge.) Rev. Path. Compt. (Paris) 12 p., 1930.

Maladies á virus du Tabac. (Virus disease of tobacco.) Phytopath. Ztschr. 2 : 321-340, 1930.

A deseription of the contents of cells from healthy and virus tobacco as seen under the ultramicroscope.

Les mosaïques des plantes tropicales et subtropicales de l'Ouest Africain. (The mosaic of tropical and subtropical plants of West Africa.) Rev. Bot. Appl. \& Agric. Col. 10(107) : 568$571,1930$.

Notes on manihot, tobaceo, peanuts and eapsicum virus diseases.

Les modifications pathologiques de structure des cellules végétales. (The pathological modification of the vegetable cell structure.) Ann. Inst. Nat. Agric. 2 ser. 23:1-104, 1930.

La modification locale du cytoplasme des cellules végétales affectées par des virus. (Local modification of the cytoplasm of vegetable cells affected with mosaic.) Compt. Rend. Soc. Biol. (Paris). 107(21) : 868-870, 1931.

La rétention de l'eau par la cellule végétale: maladies d'hypotonie et maladies d'hypertonic. Rev. Path. Compt. et Hyg. Gén. 31 : 212-223, 1931.

A study in physiology. Mosaic inhibits photosynthesis and the sugar content is low. Other diseases eause carbohydrates to be stored.

Mosaique des tulips. (Mosaic of tulips.) Compt. Rend. Soc. de Biol. 108(27) : 51-53, 1931.

The author described a mosaic in France which is similar to "breaking" 'in England.

Cytologie des cellules de plantes affectées par des maladies á cirus et de plantes carencées. (Cytology of the cells of plants affected and not affected with virus diseases.) Second Intern. Cong. Path. Compt. (Paris) 1: 309, 1931. 
Deuxiéme congrés de pathologie comparée. Second Intern. Congress of comparative pathology.) (Paris) Oct. 14-18, 1931. Phytopath. Ztschr. 4:455-459, 1932.

Discussion of virus diseases.

Die viruskrankheiten. (The virus diseases.) Phytopath. Ztechr. 5(1) : 75-83, 1932.

A study of the effects of mosaic of the chondriome. The author used Borrel's supercolation technique for the study of epidermal cells.

Die viruskrankheiten. (The virus diseases.) Phytopath. Ztechr. $5(1)$ : 85-90, 1932.

He reports elear breaking and selfbreak. Transmitted by Myzus persicae and Macrosiphum gei.

Differentiation of green and yellow mosaic virus in tobacco. Phytopathology (Abstract) 23(1): 10, 1933.

\section{Duggar, B[enjamin] $\mathbb{M}$ [inge], \& Karrer J[oanne] L[aura]*}

The size of the infective particles in mosaic disease of tobacco.

Ann. Missouri Bot. Garden 8(2) : 343-355, 1921.

Gives the results of experiments with filters which indicate the possibility of a minute organism.

\section{\& Armstrong, J[oanne] $\mathrm{K}$ [arrer] *}

Indications respecting the nature of the infective particles in the mosaic disease of tobacco. Ann. Missouri Bot. Garden, $10(3): 191-212,1923$.

After a general discussion of the subject, the authors give a review of enzyme, bacterial and protozoa theories. This is followed by a very excellent discussion of the nature of the causal agent.

The effect of treating the virus of tobaceo mosaic with the juices of various plants. Ann. Missouri Bot. Garden 12(4): 359-366, 1925.

The authors give the results of mixing the juice from tobaceo mosaic plants with the juice of other plants and pokeweed juice on Bacterium prodigiosum.

Effects of certain organic substances on the virus of the typical tobacco mosaic. Amer. Journ. Bot. (Abstract) 16(10):845, 1929. 
The nature of mosaic diseases. Proc. Intern. Congr. Plants

Sci. Ithaca, New York. 2:1231-1242, 1929.

The author reports the results of grinding and filtration experiments and says,- "I am forced to the conclusion that the infectious agency is a particle of almost inconceivably small size, certainly too small to represent an organism with the usual characteristics.

Some significant properties of the virus of typical tobacco mosaic Science (Abstract) 69(1795): 555, 1929.

The problem of seed transmission of the typical mosaic plant. Journ. of Bact. 19(1) : 20, 1930. (Rev. Appl. Mycol. 9:413, 1930. Phytopathology (Abstract) 20:133, 1930.

The results of experiments with protein and other complex substances which may be involved in the absorption of mosaic virus of tobacco. A considerable variety of seeds were used in this work. The author calls attention to the probability of some relationship of transmission of the virus to absorption and its inactivation by stored proteins.

Standardization technique in certain studies. Phytopathology (Abstract) 20(1) : 141, 1930.

\section{\& Hollaender, $\mathbf{A}$.}

Ultra violet radiation. Science n.s. (Abstract) Suppl. 72(1988) : 26, 1933.

The authors report that mosaic virus was found to resist up to 150 times the amount sufficient to kill one of the bacterial species.

Standardization and relative purification technique with plant virus preparations. Proc. Soc. Exper. Biol. \& Med. 30(8): 1104-1109, 1933.

The author describes his tentative standard method for the relative purification of the tobaceo mosaic virus.

\section{\& Johnson, Burt}

Stomatal infection with the virus of typical tobacco mosaic. Phytopathology 23(12) : 934-948, 1933.

In this paper there is presented a discussion of the technique of spraying tobaceo leaves with a virus suspension in the effort to determine whether or not stomatal infection may occur.

\section{\& Hollaender, A.}

Irradiation of plant viruses and of microorganisms with monochromatic light. I-II. Journ. Bact. 27:219-239, 241-256, 1934. 


\section{Dunlap, A[lbert] A[tkinson]}

The chlorophyll content of normal and mosaic leaves of tobacco.

Amer. Journ. Bot. (Abstract) 15(10):622, 1928.

Effects of mosaic upon the chlorophyll content of tobacco. Phytopathology 18(8) : 697-700, 1928.

Diseased plants contain less chlorophyll than normal plants.

Changes in total nitrogen, total carbohydrates, and carbon dioxide production in leaf tissue, caused by virus diseases. Amer. Journ. Bot. (Abstract) 16(10) : 844-845, 1929.

The total nitrogen and carbohydrates, and the relative rates of respiration in virus-infected plants. Amer. Journ. Bot. 17 (5) : 348-357, 1930.

These experiments showed an increase in nitrogen and a decrease in carbohydrates in the foliage of mosaic plants, and the reverse in peach yellows.

The carbohydrates of healthy and mosaic tobaceo leaves. Amer. Journ. Bot. (Abstract) 17(1047), 1930.

Carbohydrate variations accompanying the mosaic disease of tobaceo. Amer. Journ. Bot. 18(5) : 328-356, 1931.

Tobaceo mosaic diseased plants showed a reduction in the amounts of reducing sugars, disacharids, dextrin, starch and pentosans. The starch appeared to be converted into simpler compounds. Sugars accumulated to greater degree in mosaic plants.

Duriez, C.

A propos des maladies de dégénérescence de la pomme de terre. (In regard to potato degeneration diseases.) Rev. Hort. 49(14) : 367-368, 1927.

\section{Durrel, L[aurence] W[ood]}

Notes on early dwarf symptoms on Irish potatoes. Phytopathology (Abstract) 7(1):71, 1917.

\section{Dvorak, MI[ayne]}

The effect of mosaic on the globulin of potato. Journ. of Infect. Diseases. 41(3): 215-221, 1927.

The author concludes that the disease has had an influence on the precipitation of the globulin. 


\section{Dyckerhoff, $F$.}

Infektionsversuche mit der Rubenblattwouze (Piasma quadrota) au Zukerrubenkeimlingen im Jahre. Auzeig. Schadlingskunde 3: 78-84, 1927.

Bemerkunde zu dem Aufsatz von K. Boning: 1st die durch die Blattwauze hervorgerufche Erkrankung der Rube cine Viruskranheit? Auzeig. Schadlingskunde 4:17-18, 1928.

\section{Dykstra, Theodore] $\mathrm{P}$ [eter]}

Leafroll transmission from potato to other solanaceous plants by means of Myzus persicae. Phytopathology 20(10):853, 1930 .

Weeds as possible carriers of leaf roll and rugose mosaic of potato. Journ. Agric. Res. 47(1) : 17-32, 1933.

Report of experiments in transmission of leaf-roll and rugose mosaic of potatoes to solanaceous weeds.

The author concludes that the investigations have established that: under certain conditions solanaceous weeds growing in proximity to. potatoes may become infected with certain virus diseases of the crop: and may serve as sources of the infection in the crop.

Earle, F[ranklin] S[umner]

Health and disease plants. Journ. N. Y. Bot. Gard. 3: 195-202. 1902.

A popular paper in which the author refers to peach yellows, tobaceo mosaic, ete.

Instrucciones para la eradicación de la enfermedad de la caña. (Instructions for the sugar cane disease eradication.) Ins. Expt. Sta. Porto Rico Circ. 14:6-8. 1918.

Recommends the planting of healthy canes and roguing.

Informe leído ante la Asociación de Productores de Azúcar de Puerto Rico. (Report read before the Sugar Producers' Association of Porto Rico.) Rev. Agric. Puerto Rico 2(1): $5-10,1918$.

Eradication as means of control in sugar cane mosaic or yellow stripe. Ins. Expt. Sta. Porto Rico Bull. 22, 17 p., 1919.

Gives the results of field studies on distribution and methods of control and also of experiments to determine methods of transmission. 
The Year's experience with sugar cane mosaic or yellow stripe disease. Journ. Dept. Agric. Porto Rico 3(4):3-33. 1919. Gives the results of field studies for control.

The resistance of cane varieties to the yellow stripe disease. Ins. Expt. Sta. Porto Rico Bủll. 19, 19 p., 1919.

Field studies to determine relative resistance and susceptibility.

The yellow stripe or sugar cane disease. Ins. Expt. Sta. Porto Rico Ann. Rept. 1918-19: 18, 1919.

Instrucciones para la eradicación de la enfermedad del mosaico de la caña. (Instructions for sugar cane mosaic disease eradication.) Sugar 21:51-52. 1919.

A brief popular discussion.

Carta Circular No. 4. (Circular Letter No. 4.) Rev. Agric. Puerto Rico 3(1) : 51-52, 1919.

The mosaic or new sugar cane disease. Louisiana Planter \& Sugar Manuf. 63:167, 1919.

The author eriticised Mr. R. M. Gray's article (Louisiana Planter \& Sugar Manuf. 63:90) and declares that a stalk of cane once infested never recovers. Also states that Grey probably confused mosaic with other sugar-cane diseases.

El mosaico de la caña o matizado. El estado actual de la epidemia. (Sugar cane mosaic disease or mottling. The actual stage of the epidemic.) Ins. Expt. Sta. Porto Rico Cire. 22, 8 p. 1920.

Review of the work done in the Island to eradicate the disease.

La extirpación del mosaico (Mosaic eradication.) Sugar 23: 114-115, 1921.

Importantísima carta (Very important letter.) Cuba Rev. Agric. Com. \& Trab. 1(4) : 68-70, 1921.

Annual Report of the expert in sugar cane disease, 1920-21. Ins. Expt. Sta. Porto Rico Ann. Rpt. 1920-21: 59-62, 1921. 
Experiences with mosaic disease. Uba found to be immune in Cuba. South African Sugar Journ. 7(5) : 427-428, 1923. (Rev. Appl. Mycol. 2 : 525-526, 1923.)

In a report of the spread of the disease and on the immunity of some varieties.

Mosaic disease danger. Prompt action needed to stop its spread in Cuba. Facts About Sugar 16:230-231, 1923.

The disease is spreading rapidly in Cuba and very little is being done to control it.

Mosaic eradication urged. (Urge la extirpación del matizado.) Facts About Sugar 19(11) : 253, 1923 (Rev. Agric. Porto Rico 13(4) : 249-250. Australian Sugar Journ. 16(3):615-616. 1925.)

Sugar cane mosaic and sugar cane chlorosis. Facts About Sugar. $19(16)$ : 372, 1924.

A discussion of the characters of true mosaic and chlorosis.

Kavangerie in Porto Rico. (A reply to D. W. May.) Facts About Sugar 21:925-927, 1926.

Controversy.

Sugar Cane and Its Culture VII \& 355 p., 24 figs. New York. (Mosaic p. 110-124), 1928.

\section{East, $\mathbf{E}[$ dward] IM[urray], \& Weston, Jr. W[illia]m H[enry]}

A report on the sugar mosaic situation in February, 1924, at Soledad, Cuba. Harvard Inst. Trop. Biol. \& Med., Contrib. 1, 52 p. 1925. (Rev. Appl. Mycol. 5(10):582-583. 1926.)

A statement of the purpose of this Journal and a discussion of the mosaic at Soledad, Cuba.

Immunity to sugar cane mosaic acquired by the host. Proc. Nat. Acad. Sci. 17(6) : 331-334, 1931. (Sugar News 12(11) : 795-796, 1931.)

The author uses precipitin experiments according to the Uhlenhuth method. The tests not conclusive but are suggestive.

\section{Eastham, J[ohn] W[illiam]}

Some potato disease problems in British Columbia. Sci. Agric. 4(3) : 89-94, 1923. 
Plant disease survey of central British Columbia. Agric. Journ. British Columbia 9(10): 224-225, 233, 1923.

Report of Provincial Plant Pathologist, Vancouver. British Columbia Dept. Agric. Ann. Rpt. 1929. 24:135-139, 1930. Infectious chlorosis of roses; a record of this disease.

Eastwood, H. W.

Bunchy top control. Early identification, eradication of infective aphids, and destruction of diseased stools. Agric. Gaz. New South Wales 44(8):611-614, 1933.

Recommendations of practical methods for the control of bunchytop in bananas under New South Wales conditions.

Eberhardt, \& Chevalier

Un nouveau traitement pur les maladies de la Pomme de terre. (A new treatment for the potato diseases.) Rev. Hort. Algérie $30(9)$ : 200-202, 1926.

\section{Eckerson, $\mathbf{S}$ [ophia] $\mathrm{H}$ [ennion]}

An organism of tomato mosaic. Bot. Gaz. 81(2) : 204-209, 1926.

(Contr. Boyce Thompson Inst. Plant Res. 1:109-114.)

The author found flagellate organisms causing the destruction of chloroplasts in mosaic tomatoes.

\section{\& Kraybill, $\mathrm{H}$ [enry] $\mathrm{R}$ [eist]}

Separation of fern leaf from mottling in tomato mosaic. Phytopathology (Abstract) 17(1):57-58, 1927.

Edgerton, C[laude] W[ilbur], et al

The mosaic disease. Louisiana planter \& Sugar Manuf. 63: 252-255, 350, 1919.

Stenographic report of a meeting of the Louisiana State Sugar Planters' Association on the mosaic disease of sugar eane.

Mosaic or mottling disease of sugar cane. Louisiana Agric. Expt. Sta. Div. Agric. Expt. Circ. 32, 6 p., 1919. (Louisiana Planter Sugar Manuf. 62(25): 397, 1919).

Popular discussion. The presence of sugar-cane mosaic disease is reported. Similar or probably identical to that disease in Puerto Rico.

A method of selecting $\mathrm{L}-511$ cane free from mosaic disease for planting purposes. Louisiana Agric. Expt. Sta. Bull. 176, 7 p., 1920. (Louisiana Planter \& Sugar Manuf. 65 (16): 252-253, 1920.)

The eharacter of this paper is indicated by the title. 


\section{\& Moreland, C[layton] C[apers]}

Sugar cane diseases. Louisiana Agric. Expt. Sta. Ann. Rpt. 1920 : 16-17, 1920.

\section{\& Tiebout, G[eorge] L[eroy]}

Mosaic disease of the Irish potato and the use of certified seed. Louisiana Agric. Expt. Sta. Bull. 181, 15 p., 1921.

Describes the disease and gives the results of field tests with certified seed, effects on yield, and influence of climate.

Loss from mosaic. Louisiana Planter \& Sugar Manuf. 71:30, 1923.

Department of Plant Pathology. Louisiana Agric. Expt. Sta. Ann. Rpt. 1922. 34:17-18, 1923.

Tolerance and resistance to the sugar cane mosaic. Journ. Agric. Res. 29(10):501-506, 1924. (Louisiana Planter \& Sugar Manuf. 74:188-190, 1925. Rev. Appl. Mycol. 4:379, 1925.. Int. Sugar Journ. $27(321): 482-483 . \quad 1925$.

The disease spreads rapidly in Louisiana and roguing has not been successful. The results of tests with tolerant varieties are given.

\section{\& Tims, E[ugene] C[hapel]}

The sugar cane disease situation in 1923 and 1924. Louisiana Agric. Expt. Sta. Bull. 191, 44 p., 1924 (Louisiana Planter \& Sugar Manuf. 74(5) : 88-90, (6) : 110-112, (7) : 130-132, 1925. Rev. Appl. Mycol. 4:312-313, 1925.)

Gives the results of experimental work to determine resistance and tolerance.

Selecting for resistance to the sugar cane mosaic. Phytopathology (Abstract) 15(1) : 45-46, 1925.

Taggart, W[illiam] G., \& Tims, E[ugene] C[hapel] The selection of cane seed. Louisiana Agric. Expt. Sta. Bull.

195, 18 p., 1926 (Manila Daily Bull. 67(62): 15, 1926).

This paper gives the results of experiments; were very suggestive and encouraging.

\& Tims, E[ugene] C[hapel]

Investigations on the sugar cane disease situation in 1925-26. Louisiana Agric. Expt. Sta. Bull. 197 : 3-7, 1927. (Rev. Appl. Mycol. 6: 641-642, 1927).

The writers report obtaining varieties resistant to mosaic by selection of seed cuttings. 
134 THE JOURNAL OF AGRICULTURE OF THE UNIVERSITY OF P. R.

Disease resistant of P.O.J. 213 Cane. Sugar Bull. Nov. 15, 1928. (Facts About Sugar 23(50):1190, 1928. Rev. Appl. Mycol. 8: 264-265, 1928.)

A study of important varieties with reference to disease resistance.

Tims, E[ugene] C[hapel] \& IVil, P[ercy] J[oseph]

Plant Pathology. Louisiana Agric. Expt. Sta. Ann. Rept. 192829 : 52-57, 1930.

Several years' investigations of the authors showed the tolerance to mosaic disease by certain strains of sugar cane.

\section{Egiz, S[amuel] A.}

Tabakovodstvo. Glavoe Upravlenie Zemledieüa i Zemlenstroistva. Department Zemledielüa, Obshchchedostynnia Sorvschenüa sel skekhoiiaistvennykh Uchezhdnü i Spetsialistow po Sel' Skokhoziaistvennoi chasti (Russia), No. 9, 1912.

\section{Elliott, J[ohn] A[sbury]}

A mosaic of sweet and red clover. Phytopathology 11(3) : 146148, 1921.

The disease is the same as the mosaic of sweet clover (Melilotus alba), reported November 1920. Can be transmitted by cross-inoculation to Vicia faba and Medicago arabica.

\section{Elmer, Otto $\mathrm{H}[$ erman]}

Mosaic cross-inoculation studies. Iowa Acad. Sci. Proc. 29 : 205-206, 1922.

Very brief preliminary paper.

Mosaic cross-inoculation and insect transmission studies. Science n.s. 56(1448) : 370-372, 1922.

A preliminary paper. Iowa Agric. Expt. Sta. Res. Bull. 82 (1925).

Studies of insect transmission and cross-inoculation of mosaic on the Solanaceae, Cucurbitaceae and Leguminosae. Iowa Acad. Sci. Proc. 29:311-312, 1922.

Mosaic cross-inoculation studies. Phytopathology (Abstract) 14(1) : 55, 1924.

Transmissibility and pathological effect of the mosaic disease. Iowa Agric. Expt. Sta. Res. Bull. 82 : 39-91, 1925. (Rev. Appl. Ent. ser. A $13: 563,1926$.) 
This paper gives the results of a large number of cross-inoculation experiments. Also a considerable amount of data concerning insect vectors.

Inhibition of mosaic infection. Phytopathology (Abstract) 16 (1) : 67-68, 1926.

A mosaic resistant variety of cucumber. Phytopathology (Abstract) $17(1): 48$, 1927. (Trop. Agric. (Trinidad) 4:135, 1927.)

\section{Elze, D[avid] $\mathrm{L}$ [eon]}

(Insect transmission of curl disease of potato.) Int. Conf. Phytopath. \& Econ. Ent. Ann. Rpt. p. 35. H. Venman \& Sons. Wageningen, 1923.

De verspreiding van virusziekte nvan de Aardappel (Solanum tuberosum) door insects. (Transmission of virus disease of potato by insects.) Ins. voor. Phytopath. Lab. voor Mycol. en Aardappelonderzoch. Meded. 32:90, 1927. (With English summary. (Meded. Landbouwhoogschool Wageningen $31(1): 1-90,1927$.)

A classification of virus diseases with reference to insect carrier. List of insects and the results of transmission experiments.

\section{\& Quanjer, H[endrick] $\mathbf{M}[$ [arius]}

Phloemnecrose en netnecrose van de aardappel in America en Europa. (Phloemnecrosis and netnecrosis of the potato in America and Europe). Overgedrukt nit de Mededeelingen van de Landbouwhoogeschool. Deel 33(8) : 1-10, 1929. (Rev. Appl. Mycol. 9:47, 1930.)

The author made a comparative study of European and American potatoes with these diseases and gives a discussion of differences. $H_{\theta}$ believes the leaf-roll on the two sides of the Atlantic to be the same.

Die Ubertragbarkekit mit dem Samen von aukuba-Mosaik sowie blattroll. (Phloemnekrose) der kartoffel. (The transmissibility by the seed of aucuba mosaic and leaf roll. (phloemnecrosis) of the potato.) Phytopath. Zeitschr. 3(4):449-457, 1931.

The author gives the results of experiments in which he transmitted these two diseases by the seeds and by grafting.

De overgang van virusziekten met het zaad, in het bijzonder 
bijode aardappel. (The transmission of virus diseases through the seed, particularly in the potato plant.) Voordracht gehouden voor de Nederlandschs Planenzietekundige (Phytologische) Vereeningen op de Landbouweek te Wageningen op den 24 sten Juli 1931.) Tijdsch. Plantenziekt 37 (10) : 189-199, 1931.

The author gives a review of the literature and the results of grafting aucuba mosaic, leaf-roll and healthy potatoes. Some of the plants contracted the diseases.

The relation between insect and virus as shown in potato leaf roll, and a classification of viroses based on this relation. Phytopathology 21(6) : 675-686, 1931.

A discussion on the ability of several insects to transmit potato leaf-roll. Gives a classification based on relation of virus diseases to insects.

\section{Emmerez de Charmoy, D[onald] d'}

Mode de transmission de la mosaïque de la canne á sucre. (Mode of transmission of sugar cane mosaic.) Rev.. Agric. Ile Maurice $12:$ 240-341, 1923.

Mauritius: Die Mosaikkrankheit des tabaks. (Mauritius: The mosaic disease of tobaceo.) Inst. Landw. Rundschan. Rom. $19: 775,1928$.

\section{\& Guézé, $P$.}

Situation actuelle de la mosaïque á la Réunion. (Present situation of mosaic in Reunion.) Rev. Bot. Appl. \& Agric. Trop. 13(143) : 495-499, 1933.

Suggestions and description of suitable legislation tending to eradicate sugar-cane mosaic disease from Reunion.

\section{Ensign, M[artin] $\mathbf{R}$ [ussell]}

Sweet potato mosaic. Phytopathology 9(4) : 180-181. 191.9.

The author describes the symptoms of the disease and compares yieids with healthy plants and states that there is no evidence that it is transmitted directly to neighboring plants.

Eristavi, E. II., \& Mordvintzeff, A. I.

A brief survey of plant diseases in Abkhasia in 1929. (English Summary) Abkhasia Agric. Expt. Sta. Sukhum 41, 20 p., 1930.

Brief notes on tomato mosaic and white leaf spot reported as virus disease. 


\section{Esau, Katherine}

Studies of the breeding of sugar beets for resistance to curlytop. Hilgardia 4(14) : 415-441, 1930.

The author gives a brief statement concerning the disease in the United States and experimental evidence with hybrids which indicate that it is possible to develop resistant varieties.

Sugar beet resistant to curly-top. Facts About Sugar 25:610612, 1930.

Pathologic changes in the anatomy of leaves of the sugar beet, Beta vulgaris, affected by the curly-top disease. Phytopathology 23(9) : 679-712, 1933.

An extensive account of the writer's studies on the subject at the California College of Agriculture. She states that eurly-top induces pronounced anatomical changes in affected leaves involving hypertrophy, hyperplasia, hypoplasia and necrosis. She explains and describes these disorders.

Cell degeneration in relation to sieve-tube differentiation in curly-top beets. Preliminary note. Phytopathology 24(3): 303-305, 1934.

Brief preliminary notes of cytological studies made by the author.

\section{Esmarch, F[erdinand]}

Zur kenntnis des stoffwechsels in blattrollkanken Kartoffeln. (Studies on the metabolism in potato leafroll disease.) Zeitschr. Pflanzenkr. $29: 1-20,1919$. (Ang. Bot. 1:125, 1919.)

Anatomical studies of leaf-roll. The author agrees with Quanjer in regard to the translocation of starch and concludes that rolling of the leaves oceurs as a consequence of the disturbed metabolism present internally. He doubts however, that Quanjer's phloem necrosis may be regarded as cause of the reduced translocation of starch.

Beiträge zur Anatomie der gesunden und Kranken Kartoffelpflanze. Anatomie der vegetativen Organ. (Contribution to the anatomy of the normal and diseased potato plant. Anatomy of vegetative organs.) Landw. Jahrb. 54:161-266, 1919.

The author gives the results of extensive studies. He states that phloem of mature plants is always necrotic. Therefore, the phloem necrosis theory is obsolete.

Die phloemnecrose der Kartoffel. (Phloem necrosis of the potato) Ber. Deutsch. Bot. Gas. 37:468-470. 1919. 
Phloem-necrosis is found in both healthy and diseased plants, especially mature parts. When present in young plants it is evidence of premature ripening. It is of no value in diagnosing leaf-roll.

Neues von der Blattrollkrankheit der Kartoffel. (News of the leafroll disease of potato.) Naturwiss. Wochenschr. N. F. 18 : 594-595, 1919 .

Neuere Anschauungen über dir Blattrollkrankheit der Kartoffeln. (New contemplation about the leaf-roll disease of the potato). Kartoffelzeitg. 13(16). 1923. (Nachrichtenbl. Pflanzenschutzdienst $3(4): 25-26,1923$.)

Blattrollkrankheit oder nicht? (Leaf-roll disease or not?) Sächs. Landw. Zeitschr. 74: 543-545. 1926.

Das Blattrollen der Kartoffel. (The leaf rolling of the potato.) Die Kranke Pflanze 3:143-146, 1926.

Die Blattrollkrankheit der Kartoffel. (The leaf roll disease of the potato.) Monographien Zum Pflanzenschutz, 8, 91 p., 1932 .

This paper includes history, geographical distribution, economic importance, histology, physiology, transmission, environmental factors and control. The author believes the causal agent is a living entity.

Euler, [Chelpin] Hans [Karl August Simon] von, Hertzsch, W [alther IMyrback] S., Runehjelm, D[agmar Elisabet] \& Forssberg, A[rne Gunnar]

(Chemical changes in infectious chlorosis in leaves of Abutilon.) Arkiv. Kemi Mineral Geol. 10B(13):1-6, 1930. (Chemical Abstracts 25(7): 1554. 1931.)

Abutilon leaves affected with infectious chlorosis are stated to bo characterized by a much lower catalase activity, a higher proportion of amino nitrogen, less chlorophyll, xanthophyll and carotin, and less tryptophane than the normal green areas.

Recherches chemiques sur l'action de deux virus des végétaux. (Chemical investigations on the action of two viruses of plants.) Second Intern. Congr. Comp. Path. Comp. Rend. Communications $2: 459-461.1931$.

Comparative biochemical studies on tobaceo plants suffering from mosaic, Abutilon striatum with infectious chlorosis and healthy plants. 


\section{IMoritz, 0.}

Chemische Beiträge zur Kenntnis der chlorophydefekte. (Chemical contribution to the study of chlorophyll deficiency.) Ark. Kemi Mineral. Geol. Stockholm 10: A 1-15, 1931.

et al

Vergleichende Versuch über verschiedene Arten von Chlorophylldekten. Zeitschr. Indust. Abstamm. u. Vererbungsl. $60: 1-15,1931$.

\section{Evans, I[lltyd] B[uller] Pole}

Report No. VI, Botany and Plant Pathology. Journ. Agric. Dept. South Africa 9(6) :542-546, 1924. (Rev. Appl. Mycol. $4: 332-333,1925$.)

Contains references to rosette of peanuts and mosaic and streak of sugar cane.

\section{Evans, Paul}

Peach rosette. Missouri State Fruit Expt. Sta. Bull. 11, 1904. A popular paper describing the disease.

\section{Eyer, J. R., \& Crawford, R[aymond] F[rank]}

Observations on the feeding habits of the potato psyllid (Paratrioza cockerelli Sulc.) and the pathological history of the "psyllid yellows" which it produces. Journ. Econ. Ent. 26 (4) : 846-850, 1933.

Description of the symptoms of psyllid yellows. Account of the authors' studies on the mode of feeding of the insect vector of the Eyles, $\mathbf{F}$. disease, Paratrioza cockerelli.

Tobacco mosaic in Southern Rhodesia. Selection for resistance. Rhodesia Agric. Journ. 23(3) : 248-252, 1926.

A popular discussion.

\section{Faes, H[enry]}

Le portegreffes resistant á la chlorose. (Stocks resistant to chlorosis.) Prog. Agric. et Vitie 83: 83-85, 1925.

\section{Fajardo, T[ranquilino] G[anzón]}

Progress in the experimental work with the transmission of bean mosaic. Phytopathology (Abstract) 18(1): 155, 1928.

Studies on the mosaic disease of the bean (Phaseolus vulgaris

L.) Phytopathology $20(6): 469-494,1930$.

There appears to be but one mosaic disease of the bean. It develops best at 20 to 28 degrees C., is partly masked at 28 to $32 \mathrm{d \theta}$ - 
grees and completely masked at 12 to 18 degrees. The virus exists in all aerial parts of the plant and is transmitted in some seeds. It is also transmitted by Aphis rumicis, Myzus persicae, Macrosiphum solanifolii and a mealy bug.

Studies of the properties of the bean mosaic virus. Phytopathology 20(11) : 883-888, 1930.

The author continues his previous work. He compares the bean mosaic with other plant mosaic viruses and other mosaic types.

\section{\& IMarañón, G.}

The mosaic disease of Sinamar, Pachyrhizus erosus. Urban, Phil. Journ. of Sci. 48(2) : 129-142, 1932.

The authors describe a disease of sincamas,-Pachyrhizus erosus (P. angulatus).

Fallada, 0 .

(Diseases of sugar beets) Osterr. Unger. Ztschr. Zuckerindus. u. Landw. 39(1): 42-48, 1910.

\section{Faris, J[ames] $\mathbf{A}$ [braham]}

El mosaico de la caña de azúcar. Historia de esta enfermedad en la caña Dominicana. (Sugar cane mosaic. History of this disease in the Dominican cane.) Rev. Agric. Santo Domingo 17:73-76, 90-95, 105-108, 1922. (Rev. Appl. Mycol. $3: 437,1923$.)

A popular discussion of the disease and suggestions for the use of resistant varieties for control.

Proc. 2nd. Int. Conf. of sugar Cane Technologists, Havana p. 99-100, 1927.

Field control of sugar mosaic in Cuba. The Reference Book of the Sugar Industry of the World. 7:32-35. 1929.

A popular discussion with a great deal of field data concerning Cuban conditions.

Some pathological effects of the mosaic disease of sugar eane. Planter \& Sugar Manuf. 82(21) : 404-405, 1929.

El dominio del mosaico de la caña de azúcar en el campo cubano. (The range of mosaic of sugar cane in cuban plantations.) Bol. Unión Panamericana 64(9) : 968-983, 1930.

The author gives three marked zones that occur in Cuba in regard to the degree of spread of the disease. Gives the varieties best adapted to each zone and in each season. 
The utilization of varieties in the field control of sugar cane mosaic and root disease in Cuba. (A preliminary report) Trop. Plant Res. Foundation Scient. Contr. 20, 69 p., 1931. The author gives a large amount of data demonstrating that the use of resistant varieties is the most satisfactory method for the control of these diseases.

\section{Farquharson, C. 0.}

Reports of the Mycologist. Nigeria Dept. Agric. 1912-1913. 1913.

Record and description of a disease on cotton (Gossypium peruvianum and $G$. vitifolium) which the author names "Leaf curl" and has all the characteristics of a virus disease.

\section{Fawcett, G[eorge] L[orenzo]}

Una enfermedad de la caña producida por condiciones desfavorables de clima y suelo. (A sugar cane disease caused by unfavorable climatic and soil conditions.) Rev. Indus. Agric. Tueumán 8:136-140, 1917.

La enfermedad de las rayas amarillas de la caña. (Yellow stripe disease of sugar cane.) Rev. Indus. Agric. Tucumán $10: 46-48,1919$.

The disease is widely distributed on the Java varieties. Kavangerie is immune and D-1135 is resistant.

Notas sobre la extirpación del mosaico de la caña. (Notes on sugar cane mosaic eradication.) Rev. Indus. Agric. Tucumán 11:74-76, 1920.

The yellow stripe or mosaic disease in Argentina. Louisiana Planter \& Sugar Manuf. 64:41, 1920.

Reports the disease as having been in Argentine for 15 years or more. It is abundant but not serious.

Las primeras investigaciones sobre el mosaico en Java. (The first investigations on mosaic disease in Java.) Rev. Indus. Agric. Tucumán $11: 121-123,1920$.

A review of the work of Kobus and Wilbrink and Ledeboer.

Enfermedades de la caña de azúcar en Tucumán. (Diseases of sugar cane in Tucumán.) Rev. Indus. Agric. Tucumán 13(1-2) : 1-46, 1922. (Reprinted: id. 15(7-8) : 103-111, 1925. 
Estación Expt. Tucumán Bol. No. 1, 21 p., 1924. Rev. Appl. Mycol. 2: 338-340, 4(6) : 378, 1925.)

The author describes sugar-eane mosaic, which was found in all susceptible varieties cultivated in Argentine. The nature of the disease is unknown. It may be transmitted artificially, but the natural vectors are insects. Diseased canes always produce diseased plants; there is no possible cure at this time. Roguing as a means for eradication resulted in a failure, the only advisable method up to the present is the selection of healthy canes for planting.

La transmisión del mosaico. (The transmission of mosaic.) Sugar 25:684, 1923. (Rev. Indus. Agric. Tucumán 13(7-8): 129-131, 1923. Rev. Appl. Mycol. 3:367-368, 1924.)

A review of the work of Brandes and others on insect transmission.

La desinfección de la caña por la calefacción. (Sugar cane disinfection by heat.) Rev. Indus. Agric. Tucuman 13(1112) : 205-206, 1923.

This paper gives the results of attempts to control mosaic by treatment with hot water. The results were negative.

El mosaico de la eaña de azúcar. (The mosaic of sugar cane.) Rev. Indus. Agric. Tucumán 14(1-2) : 6-8, 1923 (Rev. Appl. Mycol. $3: 485$, 1924.)

A popular discussion of the subject.

El mosaico o enfermedad de las rayas amarillas de la caña. (Mosaic or yellow stripe disease of the sugar cane.) Rev. Indus. Agric. Tucumán 15(7-8) : 103-111, 1925. (Rev. Agric. Com. \& Trab. Cuba 8(1):23-29, 1926.)

A popular discussion of the mosaic including information on vectors and method of control.

La desinfección de la caña. (Sugar cane disinfection.) Sugar $27(1): 53,1925$.

A popular review of Dr. Wilbrink's hot-water treatment of cane.

Encrespamiento de las hojas de la remolacha azucarera. (Leaf curl of the sugar'beet.) Rev. Indus. Agric. Tucumán 16(3-4) : $39-46,1925$.

Sugar beets of Argentine are attacked by a disease called "Encres" pamiento" which is different from curly top. It is carried by a leafhopper, Aceratogallia sanguinolenta. 
The curly top of sugar beet in Argentine. Phytopathology 17 (6) : 407-408, 1927.

Agallia sticticollis Stal. transmits the disease.

Las manchas blancas de las hojas de la caña. (The white spots of the sugar cane leaves.) Rev. Indus. Agric. Tucumán 17: 259-261, 1927. (Louisiana Planter \& Sugar Manuf. 80:263264, 1928.)

El encrespamiento de las hojas de la remolacha y el insecto trasmisor. (The curling of the leaves of the beet and the insect vector.) Rev. Ind. Agric. Tucumán 18(5-6):61-66, 1927.

Popular discussion.

Apuntes sobre el mosaico de la caña de azúcar. (Notes on mosaic of sugar cane.) Rev. Indus. Agric. Tucumán 18 (11-12) : 205-209, 1928. (Rev. Appl. Mycol. 7:743, 1928.)

A discussion of varieties not completely immune to mosaic.

Departamento de Botánica y Patología Vegetal. (Department of Botany and Plant Pathology.) Rev. Indus. Agric. Tucumán 18(9-10) : 172-174, 1928. (Rev. Appl. Mycol. 7:562, 1928.)

Notes on different virus diseases of economic plants. Mosaic is the only important disease. Given the results of tests of P. O. J. 2725.

La clorosis de la caña recién brotada. (Chlorosis of recently sprouted cane.) Rev. Indus. Agric. Tucumán 19(7-8) : 214$215,1929$.

El cultivo y las plagas del tabaco. (The cultivation and plagues of tobacco.) Rev. Indus. Agric. Tucumán 19(7-8) : 215216, 1929.)

A brief note.

Las plantaciones de caña sin mosaico en Tucumán. (The cane plantations free from mosaic in Tucumán). Rev. Ind. Agric. Tucumán 21 : 126-127, 1931.

Report of the negative results obtained in Argentine by the roguing method for eradication of sugar-cane mosaic. 
144 THE JOURNAL OF AGRICULTURE OF THE UNIVERSITY OF P. R.

\section{Fawcett, $\mathbf{H}$ [oward] $\mathbf{S}$ [amuel]}

New symptoms of psorosis, indicating a virus disease of citrus. Phytopathology (Abstract) 23(11) : 390, 1933.

Account of record of the observations made by the author of this disease. Transmission by budding and by root euttings was successful. He also suggests that two other citrus diseases, leprosis and ring blotch, with symptoms on older leaves of the same general nature, should be investigated as to the possibility of their virus origin.

New information on psorosis or scaly bark of citrus. California Citrograph 18(12): 326, 1933.

Additional data in regard to the new virus disease studied by the author.

Fenne, S. B.

Field studies of the ringspot disease of Burley tobaceo in Wash ington County, Virginia. Phytopathology 21(9): 891-899, 1931.

Steam sterilization of soil did not prevent the disease. The stick weed (Verbesina altemifolia) and sweet clover (Melilotus alba) are natural hosts.

Ferdinandsen, C[arl Christian Frederik], Rostrup S[ofie] \& Ravn, F [rederik] K[olpin]

Oversigt over Landbrugsplanternes Sygdomme i 1917. (Report on Diseases and pests in farm crops in 1917.) Denmark. Tidskr. Plantev. Landbr. 25:314-340, 1918.

The authors mentioned 69 plant diseases in the report, among which mosaic disease on beets eaused a loss of 50 per cent of the crop and potato leaf-roll was listed as very conspicuous.

Ferguson, John H.

The particle size of biological units. Journ. Phys. Chem. 36 (12) : 2849-2861, 1932. (Rev. Appl. Mycol. 12 : 308, 1933.) A review.

\section{Fernow, Karl H[ermann]}

Spindling tuber or marginal leaf-roll. Phytopathology (Abstract) $13(1): 40,1923$.

A new host for potato mosaic (Nicandra physaloides) Phyto. pathology (Abstract) 13(1):40-41, 1923.

Interspecific transmission of mosaic diseases of plants. Cornell. Univ. Agric. Expt. Sta. Memoir $96:$ :-34, 1925. 
The author gives the results of a large number of cross-inoculation experiments. He says-"A review of the literature discloses also the fact that most authors have omitted consideration of a factor here shown to be important, namely, the identity of the mosaic concerned."

Potato growing in Bermuda. Amer. Potato Journ. 8(6):150153, 1931.

Leaf-roll potato plants give no yield in Bermuda.

\section{\& Black, L. M.}

Yellow dwarf in New York State. Amer. Potato Journ. 9(7): 116-117, 1932.

The disease has been known since 1917, severe in recent years. The severity appears to be correlated with dry weather and high temperature.

A partially masked mosaic of potatoes. Amer. Potato Journ. $10(12)$ : 235-245, 1933.

Report of results of experimental work, given in tabular form, followed by a discussion of its interpretation.

\section{Ferraris, T[eodoro]}

Peach yellows, peach rosette e l'arriciamento del pesco ín piemonte. Curiamo le Piante. Torino 6:101-114, 1928.

Fife, J. II.

A method of artificial feeding the sugar-beet leafhopper. Science n.s. 75(1938): 465-466, 1932.

A description of the method.

Figueroa, $\mathbf{C}[$ arlos] $\mathbf{A}$ [rturo]

The mottling disease of cane and the sugar production of Porto Rico. Journ. Dept. Agric. Porto Rico 3(4):35-43, 1919.

A statistical study to determine the extent of the losses.

Filho, A. F. 0.

O combato contra o "Mosaico" de canna de assucar. (The fight against the "mosaic" of sugar cane.) Brazil Agric. 12 : 65-70, 1927.

\section{Finch, A[lton] H., \& Kinnisọn, A[llen] F[isher]}

Pecan rosette: soil, chemical and physiological studies. Arizona Agric. Expt. Sta. Tech. Bull. 47:407-442, 1933.

According to the authors' statement pecan rosette has been in Arizona for over twenty years, and caused the abandonment of the orchards in several counties. They present a fully detailed account of their study of this disturbance. 
146 THE JOURNAL OF AGRICULTURE OF THE UNIVERSTTY OF P. R.

\section{Findley, W. M.}

Potato golden wonder and virus diseases. Gard. Chron. 77 (1992) : 154, 1925.

Brief popular notes.

\section{Fisher, C[ecil] E[rnest] C[laude]}

Cause of the spike disease of sandal (Santalum album). Indian Forester 44:570-575, 1918.

The author adheres to the idea of infectious nature of the disease in opposition to the autogenetic theory in support of Coleman statements. It is suggested that the disease was introduced by American missionaries on Lantana Camara which suffers from a disease whose agent is uitra-microscopic and carried by sucking insects.

Fletcher, T[homas] B[ainbrigge]

Report of the Imperial Entomologist. Agric. Inst. Pusa (India)

Sci. Rpt. 1926-27: 56-67, 1928. (Rev. Appl. Ent. Ser. A. $16: 357-358,1928$.)

\section{Flexner, S[imon]}

Some problems in infection and its control. Science n.s. 36: 685-702, 1912.

Believes that tobacco mosaic is caused by ultra-microscopic organism or filterable viruses.

\section{Foex, [Edmond] E[tienne]}

La maladie de l' enroulement des feuilles de Pomme de terre dans le conton d' Orchis nord. (The potato leaf-roll disease in the North Orchis District.) Bull. Soc. Path. Vég. France $1: 42-48,1914$.

\section{, \& Perret, Claude}

Maladies dan Pomme de terre (Potato diseases.) Vie. Agric. et Rurale 3(5) : 129-134, 1914.

Quelques causes de dégénérescence chez la pomme de terre. (Some causes of degeneration of the potato.) Journ. Soc. Nationale Hort. (France) 21:204-207, 1920.

A description of leaf-roll and mosaic and a discussion of a paper by Emile Schribaux.

Quelques causes de dégénérescence chez la pomme de terre. (Some causes of degeneration in the potato.) Compt. Rend. Acad. Agr. France 1920:398-407, 1920. 
La nécrose du liber de la tige de Pomme de terre atteinte de la maladie de l' enroulement. (Stem necrosis in potatoes affected with leaf roll.) Compte Rend. Acad. Sci. (Paris) $170(22)$ : 1336-1339, 1920.

La dégénérescence de la Pomme de terre. (Degeneration of the potato.) Journ. Agric. Pract. 33:275-279, 326-329, 344-346, 365-367, 1920.

La maladie de l' enroulement de la pomme de terre. (The leaf roll disease of potato.) Ann. Epiphytes 7:281-287, 1921.

This paper gives the results of microchemical studies on phloem necrosis.

Enroulement et leptonécrose. (Leaf-roll and leptonecrosis.) Bull. Soc. Path. Vég. (France) 8:148-149, 1921.

Les relations entre leptonécrose et l' enroulement. (Relations between leptonecrosis and leaf-roll.) Bull. Soc. Path. Vég. (France) 8(1): 25-29, 1921.

A résumé of Quanjer's studies.

Maladies á virus filtrants.-Mosaïque. (Filterable virus diseases.-Mosaic.) Rev. of (1) Butler, Edwin John. Some characteristies of the virus diseases of plants. Sci. Prog. 17: 416-431, 1923. (2) Dickson, Bertram Thomas. Studies concerning mosaic diseases. MacDonald Agric. Coll. Tech. Bull. 2, 125 p. 1922. (3) Nelson, Ray. The occurrence of protozoa in plants affected with mosaic and related diseases. Michigan Agric. Expt. Sta. Tech. Bull. 58, 28 p. 1922.) Rev. Path. Vég. et Entom. Agric. 10: 88-93, 1923.

This paper is a review of papers by Butler, Dickson and Nelson as mentioned above and a discussion of the enzymatic and parasite theories.

Les maladies á virus chez les végétaux. (Virus diseases of plants.) Rev. Path. Compa. 25(272) : 241-256, 1925; 26(293) : 39-73, 1926.

\section{Folsom, Donald}

Potato mosaic. Maine Agric. Expt. Sta. Bull. $292: 157-184$, 1920. 
148 THF .JOURAL OF AGRICULTURE OF THE UNIVERSTTY OF P. $R$.

Description and comment on effects of the disease. A study of methods of transmission and control.

\section{\& Schultz, E[ugene] S[chultz]}

Potato leaf roll. Maine Agric. Expt. Sta. Bull. 297:37-52, 1921.

Describes the disease and discusses methods of transmission and eontrol.

Potato spindle tuber. Maine Agric. Expt. Sta. Bull. 312 : 21-44, 1923.

Gives general discussion of the disease which is carried in the juice containing parts of the plant and is transmitted by Aphis. Gives recommendations for its control by seed selection, roguing and isolation.

\section{\& Schultz, E[ugene] S[chultz]}

The importance and natural spread of potato degeneration dis. eases. Maine Agric. Expt. Sta. Bull. 316, 28 p., 1924.

Gives the effects of these diseases on yield, based on experimental field studies.

Advances in the study of virus diseases of Irish potatoes in 1923. Potato Ass'n. Amer. Proc. 10th Ann. Meeting p. 3942, 1924.

A popular discussion of the subject.

Experiments and observations in Maine, 1924. Potato News Bull. 1: 316-317, 1924.

Rugose mosaic reduced the yield five times more than mild mosaic. Witches' broom was reported from Maine and transmitted experimentally.

\section{\& Schultz, E[ugene] $\mathbf{S}[$ chultz]}

Methods of conducting the seed plot and its importance in potato improvement work. Potato Ass'n Amer. Proc. 12th Ann. Meeting, 1925.

A popular discussion.

\&

Methods to be observed to prevent spread of virus diseases in potatoes grown from seed stock. Potato Ass'n Amer. Proc. 1925 Ann. Meeting $11: 20-26,1926$.

Popular. 
Virus diseases of the potato. Quebec Soc. for Prot. of Plants 18th Ann. Rpt. 18:14-29, 1926.

A popular review of the subject.

\section{Schultz, E[ugene] S[chultz], \& Bonde, R[einer]}

Potato degeneration diseases. Natural spread and effect upon

yield. Maine Agric. Expt. Sta. Bull. 331:57-112, 1926.

This paper gives much valuable data concerning the effect of these diseases on yield and on the spreading of diseases.

Uniformity of nomenclature for the viruses of Solanum tuberosum. Phytopathology 17(3):161-165, 1927. (Maine Agric. Expt. Sta. Bull. 342 (Abstract) p. 234-235, 1927.)

The author discusses the desirability of a uniform system of naming viruses.

Net-necrosis versus stem-end browning in Aroostook potatoes. Amer. Potato Journ. 7(9) : 251-256, 1930.

The author discusses these diseases with reference to regions in which the potatoes are grown and varietal susceptibility.

Virus diseases of the potato. Potato Ass'n Amer. 17th Ann. Meeting Proc. 1930: 83-101, 134-140, 1931.

A review of the recent literature (1928-1930) on the potato virus diseases is given. Considerations are given under different aspects.

Why potatoes run out. New Hampshire Hort. Soc. Ann. Rpt. 19: 90-98, 1931.

Popular account of the subject.

Potato virus diseases in 1931. Amer. Potato Journ. 9:173-181. 1932.

A review of the subject for the year.

Growing seed potatoes under an aster cloth cage. Amer. Potato Journ. March, 1934.

Description and details of an experiment conducted by the author to avoid spread of virus diseases.

\section{Forsteneichner, F[ranz]}

Die mosaikkrankheit des Manioks. (The mosaic disease of Maniocs.) Tropenflanzer 35: 349-350, 1932.

A record. 


\section{Fortún IMartínez, Gonzalo \& Bruner, Stephen C[ole]}

Investigaciones sobre la enfermedad del mosaico o rayas amarillas de la caña de azúcar. (Investigations on mosaic or yellow stripe disease of sugar cane.) Rev. Agric. Com. \& Trab. Cuba $3: 441-445,1921$.

The results of a field test with 52 varieties of cane to determine resistance and susceptibility.

El mosaico o rayas amarillas de la eaña de azúcar. (The mosaic or yellow stripe of sugar cane. Rev. Agric. Com. \& Trab. Cuba 6(1) : 4-8, 1924.

¿Cuál es el origen del matizado en Cuba? (What is the origin of mottling in Cuba?) Rev. Azucarera (Argentina) No. 374: 1089, 1924.

\section{Foster, $\mathbf{A}[$ rthur] $\mathbf{C}[$ rawford]}

"Curl" and its cure. Nat. Potato Soc. Ann. Rpt. pp 25-29, 1905 .

\section{Fracanzani, G. A.}

Mosaicatura del Tabaco. (Tobaceo mosaic) Boll. Tecn. R. Ist. Sperim, Colt. Tabacchi "Leonardo Angeloni" Scafati (Salerno) 29(4) : 244-247, 1933. (Giornale di Agric. Domenica (Italy) $10(1): 5,1933$.

Description of the disease and his experiments in Salerno, Italy, were it appears very serious. He reports his attempts to control the disease with injections of ferrous sulphate, which seems to be successful.

\section{Fracker, S[tanley] B[lack]}

Varietal susceptibility to false blossom in cranberries. Phytopathology 10 : 173-175, 1920.

A brief discussion of the subject.

\section{Frank, A. B.}

Eine neue Kartoffelkrankheit? (Is a new potato disease?) Centralb. Bakt. II. 3:403-408, 1897.

Refers to the eurl disease of potatoes.

Bemerkungen über die Kräuselkrankheit und verwandte staudenkrankheiten der Kartoffeln. (Observation of the disease of potatoes and related diseases of the stem.) Centralb. Bakt. II. 4: 683-687, 1898. 


\section{Frank, Arthur}

Mosaic, a serious disease of potatoes. Western Washington Expt. Sta. Bi Mo. Bull. 10:64, 1922.

A record of the occurrence of the disease in Washington.

Selection of disease-free berry plants. Western Washington Expt. Sta. Bi Mo. Bull. 10:110-111, 1923.

Record of four virus diseases.

Diseases and insect pests of raspberries and their control. Western Washington Expt. Sta. Bi Mo. Bull. 11: 79-81, 1923.

Facts regarding the mosaic disease of raspberry and loganberry in Western Washington. Western Washington Expt. Sta. Bi Mo. Bull. 12(2) : 48-51, 1924.

A popular discussion of the subject.

1924 information on winter injury, mosaic and other diseases of raspberries in Western Washington. Washington State Hort. Ass'n. Proc. 20:128-135, 1924.

A popular discussion of the subject.

\section{Franklin, H[enry] J[ames]}

Falșe blossom. Wisconsin State Cranberry Growers' Ass'n. Meeting 41:10-17, 1928.

Massachusetts Agric. Expt. Sta. Ann. Rpt. for the Fiscal Year ending Nov. 30, 1930. (Bull. 260). pp. 345-346, 1930.

Report cranberry false blossom.

\section{Freeman, $\mathbf{E}$ [dward] $\mathbf{M}$ [onroe]}

Report of the Division of Plant Pathology and Botany. Minnesota Agric. Expt. Sta. Rpt. 1920: 51-53, 1920.

\section{\& Leach, J[ulian] G[ilbert]}

Report of the Division of Plant Pathology and Botany. Minnesota Agric. Expt. Sta. Rpt. 1921: 74, 1921.

\section{Freeman, W[illiam] G[eorge]}

Sugar cane mosaic. Trinidad \& Tobago. Administration Report of the Director of Agric. 1922, 12 p., 1923. 
Administration Report of the Director of Agriculture of the Department of Agric. Trinidad \& Tobago, 1921, 12 p., 1922. (Rev. Appl. Mycol. 2: 394, 1923.)

Refers to campaign for the eradication of mosaic.

\section{Freiberg, G[eorge] W[illiam]}

Studies in the mosaic disease of plants. Missouri Bot. Gard. Ann. Rpt. 4(2) : 175-232, 1917.

A lengthy paper giving results of microchemical studies to determine difference in chemical elements in diseased and healthy plants. Also studies on physiological relations, plot experiments, temperature, moisture and light relations, methods of transmission and a discussion of recent investigations.

\section{Freise, $\mathbf{F}$ [riedrich] W.}

Cane diseases and plagues in Brazil. Mosaic, sereh, iliau disease and gummosis are the most prevalent.-low yields attributed largely to losses caused by these agents. Facts About Sugar 25(24) : 613-614, 1930.

A popular discussion of cane diseases in Brazil.

\section{Freitag, Julius H., \& Severin, H[enry] H[erman] P[aul]}

List of ornamental flowering plants experimentally infected with curly top. U.S.D.A. Plant Disease Reporter 17(1): 2-5, 1933.

Experiments of transmission of curly-top disease of sugar beet by the leafhopper Eutettix tenella. It was tried on 90 species of ornamental flowering plants which include 72 genera and 33 families. A list of the artificially infected plants is inserted.

Froberville, L. F. de

Degeneration of the Uba Cane. South Africa Sugar Journ. $7: 303-305,1923$.

\section{Fromme, F[red] D[enton]}

Diseases of cereal and forage crops in the United States in 1920. U. S. D. A. Br. Plant Indus. Plant Disease Bull. sup. $15: 173,1921$.

\section{$\mathrm{N}$ [oel]}

\section{Wingard, $\mathbf{S}[$ amuel] $\mathbf{A}[$ ndrew], \& Priode $\mathbf{C}[\operatorname{arl}]$}

Ring spot of tobacco; an infectious disease of unknown cause. Phytopathology $17(5)$ : 321-328, 1927.

A description of the diseased plants and the results of infection experiments. 


\section{Fukano, Hiroshi}

Effects of tobaceo mosaic upon the growth of Bac. aroideae Townsend the cause of tobaceo hollow stalk. Bulteno Scie. Fajutl. Terkult. Kjusu Imp. Univ. Fukuoka, Japan 4(1):45-51, 1930.

(A Japanese paper with English summary.) The juice from mosaic plants was passed through a Berkefeld filter and put in Czapek's solution. It accelerated the growth of the bacteria.

\section{Fukushi, Teikichi}

(On the mosaic of tobacco.) Journ. Plant Prot. 14(4) : 217-232, (5) 269-276, (6)333-339, (7)385-392, 1929.

The author gives a review of the literature, describes the symptoms and the pathological anatomy, gives the host range and the nature of the virus.

(On the cause of the tobaceo mosaic disease.) Agric. Hort. $4(11)$ : 1273-1283, 1929.

A review of the subject.

Effects of certain alkaloids, glucosides and other substances upon the infectivity of the mosaic tobacco juice. Trans. Sapporo Nat. Hist. Soc. 11(2) : 59-69, 1930. (A Japanese paper with English summary.)

The author gives the results of a series of experiments which demonstrate that tobaceo virus is very resistant to many ehemicals.

Aster yellows in Japan. Agric. \& Hort. 5 : 577-584, 1930.

No parasitic organism accounting for the disease has been found.

On the mosaic disease of broad beans. Journ. Plant Protect. $17(11): 707-712,1930 . \quad$ (12) : 779-784, 1931.

The author discusses the host range, symptom, etiology and transmission of the disease.

(On the modes of tranmission of the mosaic disease of tobacco.) Journ. Sapporo Soc. Agr. \& For. 22 (102) : 305-320, 1931.

The author discusses the methods of transmission and says that the virus was obtained in 25 out of 30 packages of commercial tobacco.

On the intracellular bodies associated with the dwarf disease of rice plant. Trans. Sapporo. Nat., Hist. Soc. 12(1) : 35-41, 1931. 
A contribution to our knowledge of virus diseases of plants in Japan. Trans. Sapporo Nat. Hist. Soc. 12(2-3) : 130-141, 1932.

A general review of the virus diseases in Japan. There are 71 species, included in 51 genera and 15 families. The new ones are Primula obconica, P. denticulata, Crotalaria juncea, Iris pumila, and I. tectomum, carnation and lilies.

On some properties of the tobacco mosaic virus. Japan Journ. Bot. 6(3) : 381-392, 1933.

A review of this phase of the subject and the results of the author's recent studies. Tobaceo mosaic virus was absorbed by kaolin and aluminia. The virus was most virulent at $\mathrm{Ph}, 4-7$.

Transmission of the virus through the eggs of an insect vector.

Proc. Imperial Acad. 9(8): 457-460, 1933.

The author demonstrated that the virus of the dwarf disease of rice could be transmitted by Nephotettix apicolis hatched from eggs of virulent parent, without the young feeding on diseased plants. This is the first record. of transmission through the eggs.

Fuller, C.

Mealie variegation. First Report Government Entomologist Natal. 1899-1900:17-19, 1901.

This is the first record describing streak disease of sugar cane.

\section{Fulmek, L[eopold]}

Pelargonien - Kräuselkrankheit. (Pelargonium - Curl disease.)

Oesterr. Gartenzeitg $12: 112-115,1917$.

\section{\& Stiff, $\mathbf{A}[$ nton]}

Ueber im Jahre 1920 orschienene bemerkenswerte Mitteilungen auf dem Gebiete der tierischen und pflanzlichen Feiden der Kartoffelpflanze. (Note worthy contributions published during 1920 to the study of insect and vegetable pests of the potato.) Centralblatt für Bakt., Abst. 2 Lief 54: (20-24); 492-529, 1921.

\section{Funaoka, S[eigs]}

Beitrage zur Kenntnis der Anatomie panaschierter Blätter. - (Contribution to the knowledge of the anatomy of variegated leaves.) Biol. Zentralbl. 44:343-384, 1924. 


\section{Gadd, C[aleb] H[erbert]}

Observations on the plot of plantains affected by the bunchy top disease at Paradeniya. Ceylon Dept. Agric. Yearbook 1925 : 36-37, 1927.

A record of testing varieties. None of them are resistant.

Bunchy top disease of plantains. Trop. Agric. (Ceylon) 66(1) : 3-9, 1926.

A general discussion and geographical distribution.

Gaget, J.

La dégénérescence des pommes de terre. (Degeneration of potatoes.) Journ. Agric. Pract. 35: 316-318, 1921.

The author discusses the relation of insects to the disease and the diffeulty of eliminating them.

\section{Gandía Córdova, Ramón}

La enfermedad de la caña. (The disease of sugar cane.) Rev. Agric. Puerto Rico. 3(1):63, 1919.

Popular account discussing the occurrence of the disease in Puerto Rico.

\section{Garbowski, L[udwik]}

Choroby virusove Ziemniaków w okrésie 1928-1932. (Virus diseases of potatoes during the period from 1928 to 1932.) Prace Wydz. Chrób Róslin Panstw. Inst. Naukow, Gospod. Wiejsk. w Bydgoszey (Trans. Phytopath. Sect. State Inst. Agric. Sci. in Bydgoszcfi), 13:3-136, 1933.

The author divides this article in two parts. Part $I$ is a review of the more recent developments in the study of potato degeneration, analyzing the two tendencies, one towards the virus principle and the other towards physiological causes. In the second part he presents a very comprehensive, detailed and tabulated account of his field observations of potato varieties from Poland, Germany, England and Holland.

\section{Garcke}

Zur Blattrollkrankheit. (Leaf-roll disease.) Die Kranke Pflanze. 3: 41-42, 1926.

\section{Gard, IM[edéric]}

Sur la chlorose de noyer cultivé. (Chlorosis of cultivated walnut.) Rev. Path. Vég. \& Ent. Agric. 3: 264-266, 1926.

\section{Gardner, Max W[illiam,] \& Kendrick, James B[lair]}

Soybean mosaic. Journ. Agric. Res. 22(2):111-114, 1921. Original description and results of inoculation experiments. 
Turnip mosaic. Journ. Agric. Res. 22(3) : 123-124, 1921.

Original deseription and results of inoculation experiments. , \&

Overwintering of tomato mosaic. Bot. Gaz. 73(6)469-485, 1922.

(Phytopathology (Abstract) 12(1): 15, 41-42, 1922.)

Evidence indicating that the disease overwinters in several species of Physalis.

\&

Tomato mosaic. Indiana Agric. Expt. Sta. Bull. 261, 24 p., 1922

Gives history, distribution, losses, susceptibility, related plants, symptoms and spread.

\&

Field control of tomato mosaic. Phytopathology 13(8) : 372$375,1923$.

Gives results of control of the disease by the eradication of virus carrying weeds. Physalis subglabrata and Solanum carolinense are the most important.

-...-.-.-.-., \&

Potato leaf-roll in Indiana. Indiana Agric. Expt. Sta. Bull. 284, 23 p., 1924.

Gives the results of yields based on experimental plantings. Also discusses spread, immune varieties and methods of control.

Department of botany report. Indiana Agric. Expt. Sta. Ann. Rpt. 1924:13-20, 1924.

Reports that potato leaf roll reduced yield from 38 to 66 per cent. Also new evidence has been obtained that a very destructive streak (winter blight) of tomatoes is a severe manifestation of mosaic.

Hyperplastic erushing of the tracheal tubes in mosaic tomato stem. Phytopathology 15(12) : 759-762, 1925.

A very interesting paper on histological studies.

Necrosis, hyperplasia and adhesions in mosaic tomato fruits. Journ. Agric. Res. 30(9) : 871-888, 1925.

A very interesting paper on histological studies.

Indiana plant diseases, 1925. Indiana Acad. Sci. Proc. 36 (1926) : 231-247, 1927.

Notes on virus diseases of bean, Trifolium arvensis, T. subterraneum, T. incarnatum, T. resupinatum, cow-pea, eggplant, pepper, tomato and velvet bean. 


\section{Kendrick, James B[lair]}

Potatoes.-A virus disease menace to tomatoes. Hoosier Hort. 9(1) : 5-16, 1927.

A popular discussion.

, \&

Potato mosaic and leaf-roll: Spread and effect on yield.

Trans. Indiana Hort. Soc. p. 158-168, 1928.

This paper gives valuable data based on field studies.

\section{Gates, R. R[uggles]}

Ultramicroscopic organisms of filterable viruses. Nature 11 (2950) : 692, 1926.

\section{Gaylord, F[ay] C[laude,] \& Gregory C[harles] T[ruman]}

More and better potatoes. Indiana Agric. Expt. Sta. Bull. 89,

24 p., rev., 1923.

\section{Geerts, J[ohannes] $\mathbb{I}$ [arinus]}

Het optreden van Strepenziekte in den westmoeson van 1923-

1924. (The occurrence of stripe disease in the west monsonn of 1923-1924.) Arch. Java Suikerind. 46:1295-1331, 1924. (Rev. Appl. Mycol. 4:244-245, 1925. Facts About Sugar $20(2): 34,1925$.)

This is a discussion of the status of the mosaic (not stripe) of sugar cane in Java at the present time. The paper contains much statistical data.

\section{Gertz, 0 [tto Daniel]}

Makrokenieska ägghivileprof a blad. (Macrochemical test ot leaves.) Bot. Not. 1917:1-35. (Zeitschr. Pflanzenk. 29: 5152 ; 1919.)

\section{Ghesquiere, J[ean]}

Sur la "mycosphaerellose" des Feuilles du manioc. (On mycosphaerellosis of cassava leaves.) Bull. Inst. Roy. Colon. Belge 3(1) : 160-178, 1932.

In a foot note to this paper the author states that the carrier of mosaic is an Aleurodid,-Bemisia mosaicivecto n. sp.

\section{Ghimpu, V.}

Bolile eu virus ale Tutunului. (Virus diseases of tobacco.) Bul. Cultivarei si Fermentarei Tutumului. Bucarest 21(2): 163-214, 1932. 
158 THE JOURNAL OF AGRICULTURE OF THE UNIVERSITY OF P. $\boldsymbol{R}$.

Detailed account of the author's field observations based on controlled experiments of four virus diseases of tobaceo occurring in Rumania. These are: mottled mosaic, ring spot, veinbanding and spot mosaic. A bibliography of 120 titles is appended. The author also considers his inoculation experiments and cytological studies of diseased tobaceo plants.

Afectuinile patologice si inamicii Tutunului din Romania in 1932. (Pathological troubles and pests of tobacco in Rumania during 1932.) Bull. Cultivarei si Fermentarei Tutunului, Bucarest. 21(4) : 9, 1932.

Notes on virus diseases of tobacco occurring in Rumania.

Sur les maladies á virus de quelques Solanées. (On the virus diseases of some Solanaceae.) Compt. Rend. Soc. Biol. 112 (11) : 1113-1115, 1933.

List and description of some Solanaceous plants which have been found affected with virus diseases in Rumania, description and classification of the diseases.

\section{Giddings, $\mathbf{N}[$ ahum $] \mathrm{J}[$ ames, $]$ Allard, $\mathrm{H}[$ arry] $\mathbf{A}[$ rdell] \& Hite, $\mathrm{B}$ [ert] $\mathrm{H}$ [olmes]}

Inactivation of the tobacco-mosaic virus by high preassures. Phytopathology 19(8):749-750, 1929. (Rev. Appl. Mycol. 9 (2) $: 138,1930$.)

No infection occurred with juice subjected to a pressure of 130,000 pounds. The enzyme zymase was inactivated at a lower pressure.

\section{Gigante, $R$ [oberto]}

Ricerche preliminari sopra un' alterazione non parassitaria delle olive. (Preliminary researches on a disorder not parasitic of the olive.) Rendic. R. Accad. Lincei. 17, 6(1):99-103, 1933.

\section{Gilbert, A[lfred] $\mathbf{H}[\mathrm{olley}]$}

Correlation of foliage degeneration diseases of the Irish potato with variations of the tuber and sprout. Journ. Agric. Res. $25(6): 255-266,1923$.

Gives the results of studies whereby the author was able to correlate symptoms of certain diseased on certain varieties.

Spindle tuber and giant hill. Potato News Bull. 1:291-292, 1924.

These two diseases are definitely recognized. 
Studies on spindle tuber of potato. Potato Ass'n. Amer. Proc. 1924 Ann. Meeting 11:101-102, 1925.

A popular discussion of the subject.

"Giant hill" potatoes a dangerous source of seed: A new phase of spindle tuber. Vermont Agric. Expt. Sta. Bull. 245, 16 p., 1925.

This paper gives symptoms and method of control.

Net-necrosis of the potato. Phytopathology 17(8):555-561, 1927.

Several types of necrosis are found in potatoes .One is definitely associated with leafroll.

Net necrosis of the potato tuber. Amer. Potato Journ. 4(8): 90-92, 1927.

Popular discussion.

Production of potato tuber necrosis. Science 67(1740):464 465, 1928.

The author grew healthy and leafroll potatoes in cages. Myzus persicae was colonized on diseased plants and then transferred to the healthy plants. When the potatoes were harvested, the healthy plants were found to show phloem necrosis.

Net-necrosis of Irish potato tubers. Phytopathology (Abstract) $19(1): 82,1929$.

Net-necrosis of Irish potato tuber. Vermont Agric. Expt. Sta. Bull. 289, 36 p., 1928. (Rev. Appl. Mycol. 9(7) : 476, 1930.) The author gives a review of the literature, a description of the disease and a very lengthy study of the histology.

\section{Gilbert, W[illiam] W[illiams]}

Cucumber mosaic diseases. Phytopathology 6(2) : 143-144, 1916. A brief statement giving the distribution of the disease.

Cucumber diseases in the Middle West. Phytopathology (Abstract) 6(1) : 104-105, 1916.

\section{Gloyer, W[alter] O[scar]}

Effect of straw mulch on potato leaf-roll. Phytopathology (Abstract) 10(1):60, 1920. 
Goddard, E[rnest] J[ames,] Magee, C[harles] J., \& Collard, H. Bunchy top in bananas, (12) Queensland Agric. Journ. 24(5): 424-429, 1925. (Fruit World Australasia 25:519-522, 1925.)

The disease is earried by an Aphid, Pentalonia nigro-nervosa. The sieve tubes undergo modifications.

Bunchy top in bananas: Final report of investigation committee. Queensland Agri. Journ. 25(6) : 506-510, 1926.

Bunchy top of bananas. Journ. Council Sci. \& Indus. Res. (Australia) 2(1): 24-27, 1929.

The disease attacks all speeies of bananas and Manila Hemp, but has not been found on any plants other than species of Musa. The author describes the symptoms and gives suggestions for its control.

Virus diseases of plants. Nature 40(1): 1929.

Virus diseases and their bearing on the cell theory and other biological concepts. Proc. Roy. Soc. Queensland $40(1): 2-$ 12,1929 .

\section{Gold, T[heodore] S[edgwick]}

Report of Commissioner on peach yellows. Connecticut Board of Agric. Sec. Rpt. 1896.

Gives a discussion with special reference to legal regulations.

Golding; F. D.

A vector of leaf curl of cotton in Southern Nigeria. Empire (,otton Growing Rev. 7(2):120-126, 1930.

Reports of experiments to determine insect vectors of "leaf curl" of cotton. It was found an unidentifield Aleurodid is able to transmit leaf curl in cotton.

\section{Goldstein, Bessie}

Cytological study of living cells of tobacco plants affected with mosaic disease. Bull. Torrey Bot. Club 51(6):261-273, 1924.

A study of the living cells of mosaic tobaceo plants in which she describes the movements of the intracellular bodies.

A cytological study of the leaves and growing points of healthy and mosaic tobaceo plants. Bull. Torrey Bot. Club 53(8): 499-599, 1926.

This paper gives a review of the literature, the symptoms of the disease, a discussion of the strains of mosaic, methods of transmission, symptomless carriers, filtration and other properties of the virus, influence of environment on symptoms and a very thorough study of the histology and cytology of diseased plants. 
The $\mathrm{X}$ bodies in the cells of dahlia plants affected with mosaic disease and dwarf. Bull. Torrey Bot. Club 54(4) : 285-293, 1927. Phytopathology (Abstract) 17(1):52, 1927.

This paper gives a discussion of the $\mathrm{X}$ bodies found in dahlia.

Nuclear form as related to funtional activities of normal and pathological cells. Bot. Gaz. 86(4) : 365-383, 1928.

A discussion of the effects of the disease on the nuclei.

Goldsworthy, M[arion] C.

Attempt to cultivate the tobacco mosaic virus. Phytopathology $16(11)$ : 873-875, 1926.

The author duplicated the work of Olitsky but the virus did not. increase in the culture.

Gontiére, J. F'.

Sur quelques maladies du tabac. (Some tobacco diseases.) Journ. Agric. Pract. 64:659-571, 1900. (Rev. Centralbl. f. Bkt. 7 : 733, 1901.)

\section{Goot, $\mathbf{P}[$ ieter $]$ van der}

Overzicht der voornaamste ziekten van het aardappelgewas in Java. (Survey of the principal disease of the potato in Java.) Inst. Plantenziekten Bull. 18, 42 p., 1924.

Aateekening over aadappeleultuur en virusziekten in Ned-Indië.

(Plans on potato culture and virus diseases in Ned-India.) Tijdschr. Plantenziekten 31:167-178, 1925.

\section{Goseco, A[ndres] $\mathbf{P}$.}

The transmission of the Fiji disease of the sugar cane. Sugar News 7(10): 736-739, 1926.

\section{Goss, $R$ [obert] W[hitmore]}

Effect of environment on potato degeneration diseases. Nebraska Agric. Expt. Sta. Bull. 26, 40 p., 1924.

This is a very thorough discussion of symptoms with reference to environments, based on field tests.

\section{\& Peltier, Geo[ge] L[eon]}

Further studies on the effect of environment on potato degeneration diseases. Nebraska Agric. Expt. Sta. Bull. 29, 32 p., 1925.

Field studies devoted largely to the influence of climatic factors on the symptoms of the various diseases. 
Effects of spindle tuber disease on sprouting. Potato News Bull. 2: 261-262, 264, 1925.

Diseased tubers sprout later than healthy tubers. Sometimes the diseased tubers fail to produce plants but form tubers from the seed piece.

A simple method of inoculating potatoes with spindle tuber disease. Phytopathology 16(3): 233, 1926.

The author's work shows that the disease can be transmitted in this manner. The loss in the next crop was 52 per cent.

Transmission of potato spindle tuber by eutting knives and seed piece contact. Phytopathology 16(4) : 299-304, 1926.

This paper gives the results of experiments which indicate that the disease may be transmitted by eutting knives and by contact with freshly cut seed pieces.

Transmission of potato spindle tuber by grasshoppers. (Locustidae) Phytopathology 18(5):445-488, 1928. (Phytopathology (Abstract) 18(1):140, 1928.)

The author presents evidence that the disease is carried by grasshoppers. He believes that the importance of the aphids has been over-estimated.

The rate of spread of potato virus diseases in Western Nebraska. Journ. Agric. Res. 39(1) : 83-74, 1929. (Rev. Appl. Mycol. 9 (1) : 51-52, 1920.)

This paper gives very interesting field data from field experiments with several virus diseases.

Insect transmission of potato-virus diseases. Phytopathology (Abstract) 20(1): 136, 1930.

Spindle tuber and unmottled eurly dwarf were transmitted by grasshoppers (Melanoplus sp.) flea beetle (Epitrix cucumeris and Systena elongata), the tarnish plant bug (Lygus pratensis) and the Colorado potato beetle (Leptinotarse decemlineata). The spindle tuber was transmitted by the leaf beetle (Disonycha triangularis).

The symptoms of spindle tuber and unmottled curly dwarf of the potato. Nebraska Agric. Expt. Sta. Res. Bull. 47, 39 p., 1930.

The author gives a review of the literature and a discussion of symptoms with reference to environment. The symptoms are modified in plants grown under glass and tuber symptoms increase under high soil moisture content and under high soil temperatures. 
Infection experiments with spindle tuber unmottled curly dwarf of the potato. Nebraska Agric. Expt. Sta. Res. Bull. 53, 36 p., 1931.

Field experiments and observations are discussed by the author.

\section{Gounaux, C[laude] B[ernard]}

Mosaic disease of sugar cane in Louisiana. Louisiana Planter $65: 269,1920$.

Recommendations for roguing.

Sugar cane test field work. Louisiana Agric. Expt. Sta. Bull. 202, 32 p., 1928. (Rev. Appl. Mycol. $7: 741,1928$. )

A report on varieties resistant to mosaic and other diseases.

\section{Gowdey, C[arlton] C.}

Relationship of insects to mosaic disease of sugar cane. Jamaica Dept. Agric. Ann. Rpt. 1924 : 19-20, $1924 . \quad$ (Rev. Appl. Ent. ser. A $12: 442-445,1924$.)

\section{Grainger, J[ohn]}

An infectious chlorosis of the dock (Rumex obtusifolius.) Leeds Phil. Soc. Sci. Sect. 1(8) : 360, 1928.

An attempt to cultivate the virus of tobaceo mosaic in vitro. Leeds Phil. Soc. Sci. Sect. Proc. 2(1):33-35, 1929. (Rev. Appl. Mycol. 9: 564, 1930.)

The appearance of bean mosaic in England. Leeds Phil. Soc.

Sci. Sect. Proc. 2(1) : 32, 1929.

The first record of this disease in England.

\& Cockerham, G.

Some properties of the virus extract of dock mosaic. Leeds Phil. Soc. Sci. Sect. 2(3) : 120-124, 1930.

Procedure of experiment is explained. Although these results did not afford conclusive proof that the cause of chlorosis in docks is a virus, they are considered sufficient to justify the provisional classification of this disturbance among this group of diseases. Rumex obtusifolius and $R$. lanceolatus were studied and observed.

\section{\& Angood, Edith}

The insect transmission of raspberry mosaic. Leeds Phil. Soe

Sci. Sect. Proc. 2(4) : 183-184, 1931.

Conclusions were reached by the authors as to capability of $A$ phis mubiphila in transmitting raspberry mosaic in England. 
164 THE JOURNAL OF AGR:CULTURE OF THE UNIVERSITY OF $P$. $R$.

The movement of tobacco mosaic virus in its host. Ann. Appl. Bio. $20(2)$ : 236-257, 1933.

Extensive work explaining his experiments on the subject.

\section{\& Heafford, Rachel IM.}

Some effects of the ordinary tobacco mosaic upon the developmental anatomy of the host plant. Proc. Leeds Phil. Soc. Scienst. Sect. 2(9): 406-415, 1933.

Brief report of the results obtained by the authors' studies of the effect on the developmental anatomy of tobacco leaf of Johnson's No. 1 virus or ordinary tobacco mosaic.

Virus diseases of plants. Oxford Univ. Press. 104 p., 1934.

A brief but very complete discussion of our knowledge of virus diseases up to date in which the author includes methods of work.

\section{Gram, Ernst}

Kan vi kontrollere vs fra Bladrullesygen. (Can potato leafroll be controlled by inspection?) Vort Landbrug (Copenhagen) $41: 416-417,1922$.

The author urges the use of localities as "sanatoria" and the practice of rigid inspection.

Forsog med oalsstedets indflydelse paa kartoffelens bladrullesyge. (Potato leaf-roll influenced by the origin of the tubers.) Tidsskr. Planteavl 28:769-806, 1922. (Int. Conf. Phytopath., Holland p. 38-39, 1923.)

A review of our knowledge of this disease with the results of field experiments. The author reports that the disease was less prevalent when May and June were cool and moist.

Einfluss des Anbauortes auf die Blattrollkrankheit der Krrtof. fel. (Influence of local conditions on the leaf roll disease of potato.) Angew Botanik 5(1):1-20, 1923.

\section{\& Rostrup, Sofie}

Oversight over Sydomme hos Landbrugets og Havebrugets kulturplanter i 1922. (Survey of the diseases of cultivated agricultural and horticultural plants in 1922.) Tidsskr. for Planteavl. 24(2) : 236-307, 1923.

\&

Oversight over Sydomme hos Landbrugets og Havebrugets Kulturplanter i 1923. (Survey of the diseases of cultivated 
agricultural and horticultural plants in 1923.) Tidsskr. Planteavl. 30(3) : 361-412, 1924.

Mosaikeyge i Drivhusene. (Mosaic diseases in greenhouses:) Gartner Tidende 8 p., 1924.

Mosaikeyge i Rodfrugterme. (Mosaic in root crops.) Vort. Landbrug 43 : 181-184, 1924.

Records of occurrence and discussions.

Mosaikeyge hos Korsblomstrede. (Mosaic in crucifers.) Dansk. Fravl., Kobenhavn (Abstract) 8:41-42, 1925.

\section{Granovsky, A[lexander] $\mathbf{A}$ [nastacievitch]}

Alfalfa "yellow top" and leafhopper (Empoasca fabae.) Journ. Econ. Ent. 21(2) : 261-267, 1928.

This disease appears to be due to a virus but the proof is not positive. It is associated with the common potato leafhopper Empoasca fabae.

Differentiation of symptoms and effect of leaf-hopper feeding on histology of alfalfa leaves. Phytopathology (Abstract) 20 (1) : 121, 1930.

\section{Grant, Theodore J.}

The host range and behavior of the ordinary tobacco-mosaic virus. Phytopathology 24(4) : 311-336, 1934.

Based on experiments the auther states that the host range of the ordinary tobacco-mosaic virus has been extended to include 29 species, representing 14 widely separated families. It was generally regarded as limited to eertain species of the Solanaceae. In the non-solanaceous hosts the symptoms are marked by variations from masked symptoms to typical chlorosis, mottling, malformations, necrosis and stunting. The distribution of the virus also varies. The author describes also the behavior of the virus in those non-solanaceous host. Also gives account of intracellular bodies associated with ordinary mosaic virus established cytologically.

\section{Gratia, A.}

Pluralité antigénique et identification sérologique des virus de plantes. (Antigenic plurality and serological identification of plant viruses.) Compt. Rend. Soc. Biol. 114(35) : 923-924, 1933.

The author followed Purdy's serological experiments with tobacco mosaic. He gives briefly but comprehensively the results obtained from which he concluded that the antigenic plurality of plant viruses is evident. 
Qualité antigénique des virus des plantes et des bactériophages. (The antigenic quality of plant viruses and bacteriophages.) Compt. Rend. Soc. Biol. 114(35) : 925-926, 1933.

Based on the results obtained in the preceding experiments the author gives his observations as to the antigenic qualities of the virus under studies. He also calls attention to the analogies between tobaceo mosaic and the bacteriophage which he is likewise inclined to refer to exogenous agency.

Identification sórologique et classification des virus des plantes. Distinction entre l' antigene mosaïque et l' antigéne vegétal. (Serologic identification and classification of plant viruses. Distinction between mosaic and plant antigen.) Compt. Rendus. Soc. Biol. (Paris) 115(11) : 1239-1241, 1934.

\section{Gratz, L[evi] 0[tto,] \& Schultz, E[ugene] $\mathbf{S}$ [chultz]}

Observations on certain virus diseases of potatoes in Florida and Maine. Amer. Potato Journ. 7(8):187-200, 1930.

The symptoms and results of these diseases are practically the same in the two places.

Diseases and climate pertaining to the Florida and Maine sections. (Potato virus diseases.) Phytopathology 20(4) : 267288, 1930.

Transmission of spindle tuber of potatoes through the usual commercial practices. Proc. Potato Assoc. Amer. 1930. 17: 73-82, 1931.

\section{Gravier, Gabriel}

Conferencia pronunciada por el, Dr. Carlos E. Chardon, Comisionado de Agricultura de Puerto Rico en la Estación Experimental Agronómica sobre la enfermedad del mosaico o matizado de la caña de azúcar. (Conference delivered by Dr. Carlos E. Chardon, Commissioner of Agriculture of Porto Rico in the Agricultural Experiment Station on "mosaic" or "mottling" disease of sugar cane.) Rev. Agric. Com. \& Trab. Cuba 7(8) : 29-32, 1925.

\section{Green, Samuel B[owdlear]}

Leaf curl of raspberry. Minnesota Agric. Expt. Sta. Rpt. p. $230,1894$. 


\section{Gregory, C[harles] T [ruman,] \& Hansen, A[lbert] A[ugust]}

Cucumber and muskmelon mosaic. Market Growers 31:180, 1922.

Popular.

\section{Grey, Robert $\mathbf{M}[$ elrose]}

The new cane disease in Cuba. Louisiana Planter 63(6):90, 1919.

The author states that the "yellow stripe" has been known in Cubs for eighteen years, that infected cuttings frequently produced healthy plants and that the disease has not caused injury. It appears to be influenced by weather.

Sobre la enfermedad del matizado en la caña. (On sugar cane mosaic disease.) Rev. Azuc. \& Agric. 1(6): 132-134, (7): 157-160, 1921. (Louisiana Planter 63:199, 1921.)

The author states that the disease which he has been studying is the "yellow stripe" and that,-Climatic conditions have a direct influence on the appearance, diminution and self-eradication of mottling chlorosis on field plants. During moist, wet, warm weather when growth action is rapid it is more readily expelled.

\section{Griffiths, David}

Daffodils. U.S.D.A. Circ. 122, 73 p., 1930.

Under "diseases" a group of conditions known as "broken" is mentioned which comprises, mottling, mosaic, yellow stripe, grey disease, etc., some of which are believed to be due to a virus.

Grieve, B. J.

"Rose wilt" and "dieback". A virus disease of roses occurring in Australia. Australia Journ. Expt. Biol. \& Med. Sci. 8 (2) : 107-121, 1931.

A description of a disease that can be transmitted by filtered juice.

Groene, F. de

Verschil in toeneme in het percentage mosaikziekte bij. Eigenheimers, verbouwd op zware Klei en lichte zavelgrond. Tijdschr. Plantenziekten 36(1) : 13-16, 1930.

The experiment showed that potato mosaic is more easily transmitted in sandy soil than in heavy loams.

Mededeelingen over proeven met. Eigenheimer in den Wilhelminapolder met. betrekking tot de verbreiding der mozaiekziekte. Landbouwk. Tidschr. 42(509): 553-561, 1930.

\section{Grove, $\mathbf{A}[$ rthur]}

Diseases of lilies. Gard. Chron. 81:178-179, 197-199, 1927. 
The diseases of lilies. Gard. Chron. 86:10, 1929.

The diseases of lilies. Gard. Chron. 88(2290)408-409, 1930.

The author calls the attention to the probability that the mosaic disease of lilies is found in the Japanese imported stock.

The diseases of lilies. Gard. Chron. 89(2302) : 110, 1931.

Short article giving explanatory notes on a series of photographs received by the author and calling the attention to the alarming increase of mosaic on lilies from imported stock from Japan.

Grubb, N. H., \& IMassee, A. IM.

Raspberry mosaic. East Malling Res. Sta. Kent, Ann. Rpt. 1923 : 131-133, 1924.

Guba, E. F.

Strawberry gold disease. Massachusetts Agric. Expt. Sta. Ann. Rpt. (Bull. 280) 1931:204, 1932.

The author reports a disease transmitted by the seed with marked stunting and necrosis, characteristies of a virus disease. Vegetative propagations aequired the disease.

"Suspected mosaic" of the strawberry. Phytopathology 23 (8) : 654-661, 1933.

The author reports a disease on strawberries named "gold leaf" in Massachusetts and restricted to the Hovard 17 variety. The same disorder is designated as "suspected mosaic", by Berkeley and "non infectious ehlorosis" by Clark. It is evidently identical with the chlorosis, yellows or xanthosis studied by Plakidas. The author concludes with a description of the disease and his observations on transmission.

\section{Gulyás, Antal}

A dohany levél márvásyozott foltossága (panaschirozottsága) és a mozaik. (A chlorosis of tobacco leaves and the mosaic disease.) Kiserletügyi Kö zlemények 31(3) : 261-273, 1928.

The author describes a chlorosis which is not a virus disease and compares it with mosaic.

Untersuchungen über die Blattfleckenkrankheiten des Tabaks. (Investigations about the leaf spot diseases of tobaceo.) Jahrb. K. ung. Land. Akad. Debrecen 1928:20-24, 1928.

\section{Güssow, $\mathrm{H}$ [ans] T[heodor]}

Leaf-roll in tomatoes. Phytopathology 6(6):447, 1916.

A leaf-roll similar in appearance to the leaf-roll of potatoes. 
Observations on obscure potato troubles. Phytopathology 8 (9) : 491-495, 1918.

In Part III potato streak disease of potato is diseussed. Streaks are similar to those sometimes found in mosaic but no connection was found between the two diseases. No organism was found. In Part II potato mosaic could not be transferred by contact but was transmitted by inarehed graft.

Bean mosaic. Canada Dept. Agr. Expt. Farms. Interin Rept. of Bot. 1921-22 : 26-27, 1922.

\section{Gutermann, C[arl] $\mathbf{E}[$ dward] $\mathbf{F}$ [rederick]}

A preliminary report on mechanical transmission of the mosaic of Litium auratum. Phytopathology 18(12) : 1025-1026, 1928. A description of methods.

The lily disease investigation fellowship. Hort. Soc. New York, Yearbook p. 34-37, 1929.

Diseases of lilies. For the lily diseases investigations fellowship. Hort. Soc. New York, Yearbook, 1930:51-152, 1931. (Final summary of the work on diseases of lilies. Boyce Thompson Inst. Prof. Paper 1(19) : 146-197, 1931.)

A part of these papers is devoted to the mosaic disease. First record by Stewart in 1896. Description of symptoms pathogenicity, transmission by Aphis gossypii and control.

\section{Haas, A[lbert] $\mathbf{R}[$ ichard] C[arl], Batchelor, L[eon] D[exter] \&} Thomas, E[1lis] $\mathbf{E}[$ dward]

Yellows or little-leaf of walnut trees. Bot. Gaz. 86(2) : 172-192, 1928.

This disease is not infectious and there is no proof that it is due to a virus.

Hach, Otto

Cane varieties, mosaic disease and fertilizers in the West Indies.

Facts About Sugar 25(16):377-379, 1930.

Popular discussion on fertilizer suggesting the use of potash to control mosaic disease on sugar cane.

Haddon, F. C.

Cane mosaic and insects. Hawaiian Planters' Rec. 32(1): 130-142, 1928, (Rev. Appl. Mycol. $7: 742-743$, 1928, Facts About Sugar 23(32): 758-759, 1928.

The author transmitted mosaic to 22 different species of grasses and obtained different characteristics. 
170 THE JOURNAL OF AGRICULTURE OF THE UNIVERSITY OF P. $R$.

\section{Haegele, R. W.}

The beet leaf-hopper (Eutettix tenellus Baker): a survey in

Idaho. Idaho Agric. Expt. Sta. Bull. 156, 28 p, 1927.

This paper does not contain any discussion of a virus disease but is of interest becausse of the relation of the insect to sugar-beet curlyleaf disease.

Field studies of the beet leafhopper Eutettix tenellus Baker.

Idaho, Agric. Expt. Sta. Bull. 182, 51 p., 1932.

This paper does not deal with a virus disease but is of value because this insect is a vector for the curly leaf of sugar beet.

\section{Hall, A. D[aniel]}

The breaking of tulip species. Gard. Chron. 85(2215):423, 1929.

Virus diseases of plants. Gard. Chron. 91(2364) : 293-294, 1932.

Brief account on virus diseases of garden plants, more especially on Monocotyledonous among which are mentioned: tulip, gladiolus, freesia, lily, iris, crocus, sternbergia, and narcissi.

The transmission of tulip breaking. Gard. Chron. 93(2420): 330-331, 1933.

Report of experiments in tulip breaking transmission by means of insect vectors. The insects used were Myzus persicae, Macrosiphum gei and Anuraphis tulipae.

\section{Hall, C[onatant] J[ohan] J[acob] van}

Ziekten en plagen der cultuurgervassen in Nederlandsch Indie in 1922. (Diseases and pests of economic plants in the Dutch East Indies in 1922.) Meded. Inst. voor Plantenziekten 58, 42 p., 1923.

Ziekten en plagen der cultuurgervassen in Nederlandsch Indie in 1923. (Diseases and pests of economic plants in the Dutch East Indies in 1923.) Meded. Inst. voor Plantenziekten, 64, 47 p., 1924.

Nine neue Kaffee-Krankheit in Nederländisch-Indien. (A new coffee disease in the Netherland Indies.) Intern. Landw. Rundschan p. 864, 1928.

Phloem necrosis of coffee. 


\section{Halle, Thore] G[ustafson]}

On leaf-mosaic and anisophylly in paleozoic equisetale. Svensk.

Bot. Tidskr. 22 : 230-235, 1928.

\section{Hallier, E.}

Die Ursache der Kräselkrankheit. (The cause of curl disease.) Zeitschr. Parasitenk. 4(2) : 48, 1875.

Historical value only.

Die Kräuselkrankheit der Kartoffeln. (The curl disease of potato.) D. Landw. Presse 79, 86, 87, 1876.

\section{Historical.}

\section{Hamann}

Die Blattrollkrankheit der Kartoffeln. (The leaf roll disease of potatoes.). Hess. Landw. Zeitg. 81:311, 1911.

\section{Hamblac, $\mathrm{H}$.}

La mosaïque de la canne á sucre. (The mosaic of sugar cane.)

Journ. Stat. Agron. Guadeloupe 3:86-91, 1923.

\section{Hamblin, Charles O[swald]}

Spotted wilt of tomatoes. Agric. Gaz. New S. Wales 32(1) : 50, 1921.

The disease appears to be infectious but the method of transmission has not been observed.

Overwintering of spotted wilt of tomatoes. Agric. Gaz. of New South Wales. 32(8) : 547, 1921.

A brief statement that this disease is earried through the winter in old plants.

\section{Hamilton, IIarion A.}

Notes on the culturing of insects for virus work. Ann. Appl. Biol. 17(3) : 487-492, 1930.

The author gives a method for keeping pure and uninfected cultures of aphides for virus work.

On three new virus diseases of Hyoscyamus niger. Ann. Appl. Biol. 19(4) : 550-667, 1932.

They are deseribed as Hy. I, Hy. II, Hy. III, Hy. IV. They oceur on other solanaceous plants including the potato. Hy. II, Hy. III, will not pass through a Chamberland or $\mathrm{L}-3$ filter but are transmitted to all hosts, except tomato, by Myzus persicae. 


\section{Hanken, H. A.}

Verslag van de proefneming gedaan in "De Wilhelminapolder" in verband met den achteruitgang van aardappel-ppotgved afkomstig van gelipke afstamming in een streck maar op verschillende grondsoort. Tijdschr. Plantenziekten 31:163$165,1925$.

\section{Hansford, C[lifford] G[erarld]}

Sugar and mosaic disease of eane. Journ. Jamaica Agric. Soc. $27(8)$ : 865-869, 1923.

History and description of the disease. Methods of transmission and control.

The mosaic disease of sugar cane. Jamaica Dept. Agric. Microbiol. Circ. 2, 14 p., 1923.

A very complete popular discussion of this disease.

Mosaic disease of canes. Journ. Jamaica Agric. Soc. 27:961964, 1923.

The author discusses the spread of the disease, methods of eradication and the results of experimental work.

Forms of mosaic disease. Journ. Jamaica Agric. Soc. 29(1): 13-14, 1925.

A brief statement of different types of chlorotic diseases. A paper read by the author, discussing infection, transmission, and necessity of control.

Mosaic diseases of sugar cane. West Indies Agric. Conf. Proc. 1924, 9: 76-82, 1925. (Rev. Appl. Mycol. 5(2) : 134, 135, 1926.)

This paper is devoted almost entirely to control and includes a a discussion of transmission by Aphis Maidis.

\section{\& Murray, P[ercival] W[aterhouse]}

The mosaic disease of sugar cane and its control in Jamaica. Journ. Dept. Agric. Microbiol. Circ. 6, 39 p., 1926. (Int. Sugar Journ. 29(341) : 240-242, 1927. Rev. Appl. Ent. Ser. A. 15: 96, 1927. Rev. Appl. Mycol. 6:185, 1927.)

This is in reality two papers. The first by the senior author giving general discussion of symptoms, cause, transmission, hosts, effects on the cane and methods of control. The second by the junior author stating his experience in field control of the disease. 
Annual Report of the Mycologist. Uganda Dept. Agric. Ann. Rpt. 1920: 48-49, 1931.

Mosaic is still the most important sugar-cane disease. P. O.J. 213, 2725 and 2727 are planted as resistant or immune varieties. Streak disease of corn prevails but is not found in sugar cane.

\section{Hanson, $\mathbf{A}$ [rthur] $\mathbf{P}$ [anton]}

Mosaic disease. Journ. Jamaica Agric. Soc. 28: 242-243, 1924. The author discusses symptoms, effects and methods of control.

\section{Haring, C[larence] MIelvin]}

The beet leafhopper Eutettix tenella, Baker. California Agric.

Expt. Sta. Ann. Rpt. 1920-21:41-42, 1922.

Harreveld, $\mathrm{Ph}$ [ilippus] van

Strepenziekte in bibittuinen (Stripe diseases in nurseries.) Arch. voor de Java Suiker Indus. 18:919-922, 1919.

An unusual outbreak of the disease in nurseries was noticed this year. Planting of healthy cuttings improved the conditions.

Gelestrepenziekte en bladuizen. (Yellow-stripe disease and leaf lice.) Arch. voor de Java Suiker Indus. 30(16) : 261-262, (17) : 362-364, 1922. (Korte Meded. Proefstation Java Suiker Indus. No. 4, 1922.)

A popular discussion.

\section{Harrington, F[rank] IVI.}

Tuber indexing versus tuber-uniting and roguing in seed po-

tato production. Amer. Potato Journ. 9(8): 128-131, 1932. A summary of field studies.

\section{Harris, R. V.}

Grafting as a method for investigating a possible virus disease of the strawberry. Journ. Pom. \& Hort. Sei. 10(1) : 35-41, 1932 .

Description of method.

The strawberry "yellow edge" disease. Journ. Pom. \& Hort. Sci. 11(1) : 56-76, 1933.

Account of two years experimental work, the results of which showed that the disease is of the virus type transmissible by grafting, gives method of control.

The commercial control of raspberry-mosaic disease. East Malling Res. Stat. Ann. Rpt. 1932:149-151, 1933. 
174 THE JOURNAL OF AGRICULTURE OF THE UNIVERSITY OF P. R.

Description of work done on the establishment of mosaic-free nurseries of raspberries. Full directions are given for the planting and maintenance of such nurseries.

\section{Hart, W. C., \& Rengaswamy, s.}

Preliminary investigations into the cause and cure of spike diseases of sandal (Santalum album) in the North Salem Division. Madras Presidency. Indian Forester 52(8):373-390, 1926.

An outline of methods.

\section{Harter, L[eonard] L[ee], \& Whitney, W[ill] A[lvah]}

Masking sweet potato mosaic. Phytopathology 19(10) : 933942, 1929; (Rev. Appl. Mycol. 9: 267, 1930.)

The author reports the masking on new growth at 38 degrees $\mathbf{C}$.

\section{Hartley, Carl Pierce}

Pale dwarf disease of plant (Arachis hypogaea). Phytopathology $17: 217-225,1927$.

A report on a disease found in Java. The author has found this disease in seedlings grown from seed from Africa.

\section{Haasis, Ferdinand W[ead]}

Brooming disease of black locust (Robina pseudoacacia). Phytopathology 19(2) : 163-166, 1929.

A description of a disease resembling peach yellows but the authors do not give any proof that it is caused by a virus.

A Brooming disease of Robina pseudoacacia transmitted by grafts. Phytopathology (Abstract) 23(1):13, 1933.

\section{Harvey, $\mathbf{R}$ [oney] $B$ [eecher]}

Hydrogen-ion changes in the mosaic disease of tobaceo plants and their relation to eatalase. Journ. Biol. Che. 42:397-400, 1920.

\section{Haskell, Royal J[oyslin], \& Martin, George H[amilton]}

Summary of plant disease in the United States in 1918. II Diseases of field and vegetable crops. U.S.D. A. Br. Plant Industry. Plant Disease Bull. Suppl. 2:42-83, 1919.

The Fiji disease of sugar cane. Trop. Agric. (Ceylon) 56: 381-383, 1921.

\section{Wood, Jessie I [da]}

Diseases of cereals and forage crops in the United States in 1928. U. S. D. A. Plant Disease Reporter Suppl. 71:259-323, 1929. (Rev. Appl. Mycol 9(2) : 93, 1930.) 


\section{\& Archer, William A[ndrew]}

Salsify yellows. U.S.D.A. Plant Disease Reporter 13:139140. (Rev. Appl. Mycol. 9:224, 1930.)

United States of America: Plant Disease survey notes. International Bull. Plant Protect. 3:179-180, 1929. (Rev. Appl. Mycol. 9:288; 1930.)

Reports celery yellows caused by aster yellows virus and transmitted by Cicadula sexnotata.

\section{\& Wood, Jessie I[da]}

Diseases of plants in the United States in 1929. U.S.D.A. Plant Diseases Reporter Suppl. 75.

\section{Handuroy, .P.}

Les untravirus. Deuxiéme Congr. Intern. Path. Comp. (Paris) Rpts. 1 : 321-338, 1931.

\section{Hause, $\mathrm{H}$.}

Transfer of variagation from scion to stock. Gard. Chron. 1893 : 849, 1893.

It refers to Horse chestnut.

\section{Hawley, I [ra] $\mathbb{M}$ [yron]}

Relation between curly-top and beet leaf hopper. Utah Agric. Expt. Sta. Misc. Pub. No. 3. 1927.

Hayes, T. $\mathbf{R}$.

Groundnut rosette disease in the Gambia. Trop. Agric. (Trinidad) 9(7) : 211-217, 1932.

A review of our knowledge of the subject with the results of studies of weed carriers.

\section{Heald, F[rederick] D[e Forest]}

Division of Plant Pathology. Washington Agric. Expt. Sta. Bull. 245 : 47-50, 1930.

The works of $\mathrm{L}$. $\mathrm{K}$. Jones are reported in regard to the rate of spread of tomato streak. Brief notes on other virus diseases are given.

Forty-second Annual Report Washington Dept. Agric. for the fiscal year ending June 30, 1932. Washington Agric. Expt. Sta. Bull. 275, 34 p., 1932.

Account of studies on little leaf or rosette of apple, peach and cherry, and latent veinbanding viruses of potato. 


\section{\& Burnett, G.}

A virus disease of perennial delphiniums. Bull. Amer. Delphiniums Soc. 2(2) : 14-21, 1934.

\section{Hédin, L[ouis]}

Culture du manioc en cŏte d' Ivoire; observations complémentaires sur la mosaïque. (Culture of manioc in Ivory Coast supplementary observation on mosaic.) Rév. Bot. Appl. Agri. Trop. 11: 558-563, 1931.

\section{Hedlund, [Johan] T[eodor]}

(Some observations on the leaf-roll disease of the potato) Tidskr. Landtman. $31: 512-515,532-541,1910$. (Abstract: in Bot. Centralbl. 114(22) : 567-568.) 1910.

Uber die gewöhnchsten krankheiten der kartoffel. (About the common diseases of potato.) Tidskr. f. Landtman, 15 p., 1913.

\section{Heim, Roger}

Maladies á virus et maladies bactériennes des plantes coloniales; état actuel de la question. (Virus and bacterial disease of colonial plants; actual state of the question.) Cryptog. Exotique, (Paris) 4(2): 104-110, 1931.

\section{Hein, I[1lo]}

Changes in plastids in variegated plants. Bull. Torrey Bot. Club. 53: 411-418, 1926.

The author makes a study of a number of plants and says:-“"In all these cases it would seem that the spotting must be caused by a chlorophyl destroying agent which spreads radially and disorganizes the plastids as it penetrates from cell to cell."

\section{Heintzel, K[urt Gustav] Emil}

Contagiose Pflanzenkrakheiten ohne Microben unter besonderer Berücksichtingung der Mosaikkrankheit der Tabakablätter. (Contagious plant diseases not bacterial on peculiar contact transmission of the mosaic disease of tobacco leaves.) Inang Diss. Univ. Erlangen, p. 1-45, 1900.

\section{Hell, W. F. van}

Onderzockingen over Ziekten van Lilies. (Investigations on lily diseases.) Theasis Univ. of Utracht, 116 pp., 1931.

The author records yellow flat in Holland on L. longiforum var, giganteum and formosum and mosaic on L. longiflorum, L. aurantum and L. speciosum. 


\section{Ienderson, L[ouis] $\mathbf{F}$ [ourniquet]}

Tomato blight. Idaho Agric. Expt. Sta. Ann. Rpt. 1904:155, 1905.

\section{Ienderson, $\mathbf{R}$ [obert] $\mathbf{G}$ [ordon]}

Transmission of tobaceo ring spot by seed of Petunia. Phytopathology 21(2) : 225-229, 1931.

The author discusses the subject briefly, giving results of experimental work.

\section{\& Wingard, $\mathbf{S}[$ amuel] $\mathbf{A}[$ ndrew]}

Further studies on tobacco ringspot in Virginia. Journ. Agric.

Res. 43(3) : 191-207, 1931.

Natural infections on many plants have been reported. The symptoms differ from true ring spot in severity. It has been suggested that this is due to attenuation of the virus. Jimson weed and cataloupe are natural hosts. Thermal death point is between $60^{\circ}$ and $70^{\circ} \mathrm{C}$. The virus is readily inactivated by desiccation. The paper contains much other valuable data.

Increasing the resistance of tobacco ring spot virus to ageing $i n$. vitrio by use of carbolic acid. Phytopathology (Abstract), 23(1) : 14-15, 1933.

Effect of air temperature on tobaceo ring-spot infection. Phytopathology (Abstract) 24(1):10-11, 1934.

Occurrence of tobacco ring-spot-like viruses in sweet clover. Phytopathology 24(3) : 248-256, 1934.

Discussion of the natural occurrence of ring-spot-like viruses on sweet clover. The authors reports a new virosis of sweet elover, describing its symptoms. The virus is infectious on tobaceo, producing symptoms of the necrotic-pattern type but distinctly different from the symptoms of ring spot.

\section{Ienderson, W. J.}

Indexing as a control measure for the yellow dwarf disease of onion. Phytopath. (Abstract) 20(1):115, 1930.

Varietal susceptibility, distribution and control of yellow dwarf onion. Phytopathology (Abstract) 21(1) : 123, 1931.

Studies of the properties and host reactions of the onion to the yellow dwarf virus. Phytopathology (Abstract) 22(1):11, 1932 . 
178 THE JOURNAL OF AGRICULTURE OF THE UNIVERSITY OF P. R.

\section{Henning, E[rnst Johan]}

Kort översikt over vitktigare smittosamme sjukdomar hos potatisen. Stockholm: Wilhelmssons Boktr. 28 p., 1915.

\section{Herbert, D. A.}

Bitter pit of apples. The crushed cell theory. Phytopathology $12(10): 489-491,1922$.

Discussion of the theory. Written before the cause was known.

\section{Heribert-Nilsson, $\mathbf{N}$ [ils]}

Sortshesistens och lokalinfectionsfrihet med avseende pa bladrullsjukan hos potatis. (Varietal resistance and local freedom from infection in connection with potato leaf-roll.) Weibull Arsbok 21 : 30-33, 1927.

\section{Hernández, Adrián}

Yellow stripe disease of cane in the Philippines. Sugar Central \& Planters' News 1:36, 1920.

Mosaic diseases. Philippine Islands Br. Agric. Ann. Rpt. 1923: 167-168, 1924.

\section{Hernández Torres, C.}

Control del "mosaico" o "rayas amarillas" de la caña de azú. car. (Control of "mosaic" or "Yellow stripe" disease of sugar cane.) Rev. Agric. Com. \& Trab. Cuba 10(4): 16, 1928.

\section{Hertzsch, Walther}

Beitrage zur Infektiösen Chlorose. (Contribution on infectious chlorosis.) Zeitschr. für Bot. 20(2-3) : 65-85, 1927.

Two infectious diseases of Abutilon which have been confused by earlier writers.

Infektiöse chlorosen. (Infectious chlorosis.) Der Züchter 2 (7) : 196-199, 1930.

The author reports two forms of infectious chlorosis A \& B in Abutilon and other Malvaceae.

Heuberger, J. W., \& Moyer, A[ndrew] J.

Influence of mosaic infection on tomato yields. Phytopathology 21(7) : 745-749, 1931.

Tabulated results of experiments are given. Late infections cause less losses than early infections.

\& Norton, J. B. S.

Water loss in tomato mosaic. Phytopathology (Abstract) 23 (1) : 15, 1933. 
$\&$

The mosaic disease of tomatoes. Maryland Agric. Expt. Sta. Bull. 345 : 447-486, 1933.

Popular.

\section{Hiltner, L[orenz]}

Einige Bemerkungen über die Blattrollkrankheit der Kartoffeln.

(Some observations on the leafroll disease of potatoes.)

Prakt. Bl. Pflanzenb. u. Pflanzensch. 4:25-30, 1908.

Ueber den Zusammenhang der Blattrollkrankheit der Kartoffel in Bayern. (The actual state of ring and leaf roll disease of potatoes in Bayern.) Prakt. Bl. Pflanzenb, u Pflanzensch. 6: 86-87, 1908.

\section{\& Gentner, G[eorge]}

Ueber den Zusammenhang der Blattrollkrankheit der Kartoffel mit der Stärkeanhänfung in ihren Blättern. (On the relation of leafroll disease of potato with the starch accumulation in its leaves.) Prakt Bl. Pflanzenb. u. Pflanzensch. 16: 138-141, 1918.

Versuche uber die Uraschen der Blattrollkrankheit der Kartoffel. II Weitere Beobachtungen uber die "Stärkeschoppung" in Blattrolkranken Kartoffelstanden. Praktische Blátter fur Pflanzenbau und Pflanzenzencht. (Munchen) 17: 15-19, 3949, 1919.

\section{Himmelbaur, Wolfgang.}

Die Blattrolkrankheit der Kartoffel. ('The leaf-roll disease of the potato.) Wiener. Landw. Zeitg. 74:43-44, 1924.

\section{Hind, $\mathbf{R}$ [obert] $\mathbf{R}$ [enton]}

Toledo cane, a mosaic-immune variety. Sugar Central \& Planters' News 4(3) :105-107, 1923. (Rev. Appl. Mycol. 2:468, 1923.)

\section{Hinson W[alter] IM., \& Jankins, E[dward] H[opkins]}

The management of tobacco seed beds. Connecticut Agric. Expt. Station. (New Haven) Bull. 166, 1910.

A brief reference to calico (mosaic) in the seed beds. 


\section{Hockey, J[ohn] Fred[erick]}

Report of the Dominion Laboratory of Plant Pathology. Canada Dept. Agric. St. Catherine, Ontario Div. Bot. Rpt. 192223 : 32-43, 1923.

Mosaic and leaf curl of the cultivated raspberry. Canada Expt. Farms Cire. 1, 4 p., 1923.

The control of raspberry mosaic. Phytopathology (Abstract) $13(6): 292,1923$.

The control of spread of mosaic of potatoes by the use of nicotine dust. Rpt. Dom. Bot. 1927: 205, 1928.

\section{Hodgson, C. M.}

Spiked sandal wood. Indian Forester 44:66-71, 1918.

Spike disease of sandal. Indian Forester 44:325-334, 1918. "I write to record my opinion that spike is not caused by fire, Zyzyphus, Lantana (L. Camara) or any other of the environment but an internal ailment due to some germ or to some pathological condition."

\section{Hodson, W[illiam] E[dgar] H[umphreys]}

Narcissus pests. Min. Agric. \& Fisheries Bull. 51, 1932.

Hoffman, INI.

Plant diseases. Jahresber. Land. 24: 203-210. 1909

\section{Hoggan, Ismé A[ldyth]}

Cytological studies on virus diseases of solanaceous plants. Journ. Agric. Res. 35(7) : 651-672, 1927.

This paper gives a brief review of the literature and the results of a very thorough study on the virus diseases of a number of solanaceous plants. Special attention is given to the $\mathrm{X}$-bodies and other materials. "It is believed that the evidence presented in this paper is on the whole in favor of the view that the $\mathrm{X}$-bodies are not of the nature of a causal organism."'

\section{\& Johnson, James}

"Not Guilty"' is the verdiet against peach aphids. Wisconsin Agric. Expt. Sta. Bull. 405: 115-116, 1929.

Based on field observations and experimental tests the authors found out that Myzus persicae is not a vector of tobaceo mosaic disease. 
The peach aphids (Myzus persicae Sulz) as an agent in virus transmission. Phytopathology 19(2) : 109-123, 1929.

Mysus persicae transmitted cueumber virus to tobaeco and other solanaceous plants and from tobaceo to tobaceo, but it did not transmit tobaceo mosaie from tobaceo to tobaceo.

Transmission of cucumber mosaic to spinach. Phytopathology 20 (1) : 103-105, 1930.

Virus from mosaic cucumbers was transmitted to spinach by Myzus persicae and Macrosiphum sclanifolii. The symptoms resembles those of spinach blight.

Aphid transmission of plant viruses. Phytopathology (Abstract) $20(1): 133,1930$.

Studies on aphid transmission of plant viruses. Journ. Bact. 19(1) : 21-22, 1930. (Rev. Appl. Mycol. 9:413, 1930.)

Greenhouse experiments demonstrated that: (1) Myzus pseudosolani, and Macrosiphum solanifolii can transmit tobaceo mosaic virus from tomato to other solanaceous hosts, but cannot transmit it to tobacco. (2) Can transmit cucumber mosaic virus from tobacco and tomato. (3) Myzus circumflexus can transmit cucumber mosaic from tobaceo and tomato but eannot transmit tobaceo mosaic from tobaceo.

Further studies on aphid transmission of plant viruses. Phytopathology 21(2) : 199-212, 1931.

Studies on aphid vectors were conducted on different species of aphids to determine their ability to transmit the viruses of ordinary tomato mosaic. Evidence showed that aphids are unlikely to be responsible for any dissemination of ordinary tobaceo mosaic, so far as tobaceo is concerned.

Some factors involved in aphid transmission of the cucumbermosaic virus to tobaceo. Journ. Agric. Res. 47(9) : 689-704, 1933.

Report of the results of experiments obtained, given in detail. The aphid under study was Myzus persicae.

Some virus affecting spinach, and certain aspects of insect transmission. Phytopathology 23(5) : 446-474, 1933.

Results of observations and experiments made by the author in re- 
gard to the transmissibility of different viruses on Spinach (Spinacia oleracea) e. g. cucumber mosaic, sugar beet mosaic and tobacco ring spot mosaic virus diseases.

Holden, J. A.

Spindel-tuber disease. U.S.D.A. Circ. 5:27-28, 1927.

Report of an experiment to determine whether the spindle-tuber disease of potatoes is carried by irrigation water. The experiment gave negative results.

\section{Hole, R[obert] S[elby]}

Spike disease of sandal. Indian Forester 44:325-334, 1918.

A review of a paper by Venkataraman Ayyar (Indian Forester 44: 316-324) defending statements in a previous paper (Indian Forester 44: 430.) The disease was probably present before 1898. Believes that trenching experiments should be continued. Injury by fire may be a factor under dry conditions.

Spike disease of sandal. Indian Forester 44:461-462, 1918. Criticism of paper by Lushington and a defense of his own opinion.

Cause of the spike diseases of sandal. (Santalum album.) Indian For. 43:429-442, 1917. (Bot. Abs. 2:215, 1919.)

Cause of the spike disease of sandal. Indian Forest 45:133139, 1919.

Further information of the disease given in previous artieles.

Holland, T. H.

Plantains and bunchy top. Trop. Agric. (Ceylon) 66(2): 125, 1926.

Report of measures of control of the disease, which were unsuccessful.

Hollins, E.

Discussing eurl or degeneration of potatoes. Trans. Soc. Encouragement of Arts. Manuf. and Commerce 8, 1790. Read the 20th October, 1789.

Historical value.

Hallowell, E. A., IMonteith Jr., John., \& Flint, W. P.

Leaf hopper injury to clover. Phytopathology (Abstract) 17 (1) : 58, 1927.

Not due to a virus, but the symptoms are similar.

\section{Hollrung, Max}

(Annual Report on Plant Diseases.) Jahresber. Pflanzenkrank. $12(8): 356,1909$. 


\section{Holmes, Francis 0[liver]}

Monochromatic light photography in the study of mosaic disease. Phytopathology (Abstract) 18(1): 154, 1928.

Accuracy in quantitative work with tobacco mosaic virus. Bot. Gaz. 86(1) : 66-81, 1928.

A description, a method and the result of the experimental work.

Accuracy in comparing various eoncentrations of tobacco mosaic virus. Phytopathology (Abstract) 18(1):132, 1928.

Describes method of inoculation with needles and experimental results.

Cytological study of the intracellular body characteristic of Hippeastrum mosaic. Bot. Gaz. 86(1) : 50-58, 1928.

The author reports that no nucleus was found in the bodies but chondriosome were found. "Whether the body represents a stage in a foreign organism, a mass of plant cell cytoplasm containing virus, or a mass of the plant cell cytoplasm not immediately in contact with virus but stimulated by the diseased conditions is not known."

Ultra-violet light photography in the study of plant virus. Bot. Gaz. 86(1) : 59-65, 1928.

Gives results of photographic experiments for purpose of finding special structure in mosaic plants. The results were negative.

Local lesions in tobacco mosaic. Bot. Gaz. 87(1) : 39-55, 1929.

(Contri. Boyce Thompson Inst. 1:504-520, 1929.)

Gives the results of the inoculation of a number of species of Nicotiana with common tobaceo mosaic. Five species developed lesions. Gives a "standardized method for using $N$. glutinosa as a test plant for measuring the concentration of mosaie virus.

Inoculating methods in tobaceo mosaic studies. Bot. Gaz. 87 (1) : 56-63, 1929. (Contr. Boyce Thompson Inst. 1:521-528, 1929.)

This paper gives the results of several methods of mechanical inoculation and recommends the application of the virus to the surface before making the wounds.

Local symptoms of mosaic in the leaves of some Nicotiana species. Phytopathology (Abstract) 19(1):92-93, 1929. 
Local and systemic increase of tobacco mosaic virus. Amer. Journ. Bot. 17(8) : 789-805, 1930. (Boyce Thompson Inst. Contrib. 2(10) : 563-579, 1930.)

By means of measurements the author studies the concentration of virus in relation to local lesions and its spread in the plant.

Local lesions of mosaic in Nicotiana tabacum L. Boyce Thompson Inst. Contrib. 3(2): 163-171, 1931.

Local lesions of mosaic in Nicotiana tabaoum L. are described and discussed.

Local lesions of mosaic in Nicotiana tabacum. Phytopathology (Abstract) 21(1) : 119, 1931.

Movement of mosaic virus from primary lesions in Nicotiana tabacum L. Boyce Thompson Inst. Contr. 4(3) : 297-322, 1932.

A thorough description of the author's observations of the movement of the mosaic virus in primary lesion in Nicotiana tabacum $\mathbf{L}$. with description of symptoms produced by artificial inoculations.

Symptoms of tobacco mosaic disease. Contr. Boyce Thompson Inst. $4(3): 323-357,1932$.

The author describes primary and secondary symptoms resulting from inoculating tobaceo mosaic virus into Nicotiana, Solanum, Capsicum, Lycopersicum, Datura, Petunia, Nicandra, Lycium, Hyoscyamus, Marytynia and Phaseolus. The descriptions include a number of symptoms not recorded by previous workers.

Masked strain of tobacco-mosaic virus. Phytopathology (Abstract) 24(1): 11-12, 1934 .

Holmes Smith, (A) E.

Spotted wilt disease of tomatoes. Gard. Chron. 94(2445): 350, 1933.

Account of the occurrence of an outbreak of spotted wilt disease of tomatoes in Manchester (England). Description of the effect of the disease on the plant and on the erop. The author suggests the applications of calcium cyanide or the dusting of the foliage with naphthalene to eontrol Thrips tabaci the vector of the disease.

Hoog, J.

The breaking of tulips. Gard. Chron. 94(2452):471, 1933. Brief historical note of this disorder in tulips. 


\section{Hopkins, J[ohn] C[ollier] F[rederick]}

Mosaic disease of tobacco. Rhodesia Agric. Journ. 25:188194, 1928.

A popular paper.

Leaf spotting of tobacco caused by mosaic. Rhodesia Agric. Journ. 26(9) : 912-916, 1929. (Rev. Appl. Mycol. 9(2) : 138, 1930.)

A description of this type of mosaic on tobacco.

Plant Pathology in Southern Rhodesia during the year 1930. Rhodesia Agric. Journ. 28(4) : 384-389, 1931.

Masked tobacco mosaic is reported. Also ring spot virus disease of tobacco as a new record.

Leaf curl of tobacco in Southern Rhodesia. Rhodesia Agric. Journ. 29(9) : 680-686, 1932.

This paper gives the results of experimental studies. The disease is carried by white flies (Aleurodidae).

\section{Hori, $\mathbf{s}$.}

(Material for the study of dwarf diseases.) Journ. Plant Protect. 7:667-671, 1920; 8:117-120, 1921.

(Chlorosis or mosaic disease of cucurbits.) Agric. World 17 (16) : 22-30, 1922.

\section{Horne, $\mathbf{A}[$ rthur] $\mathbf{S}[$ amuel]}

The symptoms of internal disease and sprain, Journ. Agric. Sci. 3: 323, 1910.

On the potato leaf blotch and leaf eurl. Journ. Roy. Hort. Soc. (London) 36(3): 618-623, 1911.

Blotch and streak in potatoes. Journ. Roy. Hort. Soc. (London) $39(3): 607-614,1914$.

\section{Horne, W[illia]m T[itus,] \& Parker E[dwin] $\mathbf{R}$.}

The avocado disease sun blotch. Phytopathology (Abstract) $20(10): 852,1930$.

Record of a disease of avocado in California with characteristics of an infectious chlorosis. 
The avocado disease called sun blotch. Phytopathology 21: 235-238, 1931.

The disease is thought to be an infectious chlorosis.

The avocado sun-blotch disease. California State Dept. Agrie. Mo. Bull. 20 (7) : 447-454, 1931.

Popular article describing the disease. Practical methods of control are suggested.

Avocado diseases in California. Phytopathology 22(1): 12-13, 1932.

Abstract in which the author states that "Chlorosis and little leaf apparently parallel similar diseases of eitrus. Sun blotch, is an infectious disease."

\section{Horsfall, J[ohn] L[ouis]}

The effects of feeding punctures of Aphids on certain plant tissues. Penn. Agric. Expt. Sta. Bull. 182, 1923.

Gives the results of histological studies by which the author was able to follow the course of the probosis in the tissue of the plant.

\section{Howard, Albert}

Spike disease of peach trees, an example of unbalanced sap circulation. Indian For. 45:611-617, 1919.

The author believes that sandal spike is similar to peach spike and that it is due to the imperfect union of the root haustoria with the host.

Agriculture and Science. Agric. Journ. of India. 21(3) : 171182, 1926. (Sugar News 7(6):381-386; (7) :471-477; (8): 537-543, 1926.)

\section{Howdeniensis}

On the curl in potatoes. Young's Ann. Agric. 43:595-596, 1805.

\section{Howitt, John E[aton]}

Raspberry yellows and eane blight. Canad. Hort. 36(10) : 237238, 1913.

\section{\& Stone, R[oland] E[lisha]}

A troublesome disease of winter tomatoes. Phytopathology 6 (2) : 162-166, 1916.

This is evidently a virus disease but was not recognized as such at the time of the publication of this paper. 
Botany. Ontario Agric. Col. \& Expt. Farms, Ann. Rpt. 1918. 44 : 19-21, 72-78, 1919.

Brief references to mosaic diseases. Results of field studies.

Some observations made in inspecting for leaf-roll and mosaic. Phytopathology (Abstract) 10(5):316, 1920.

\section{Hunger, Friedrich W[ilhelm] T[obias]}

Die Mosaick-ziekte by Deli Tabak. (The mosaic disease on Deli Tobacco.) Deel. 1 Meded. unit. S' Lands. Plantentuin 63, 104 p., 1902.

Een voorloopige verlaring optreden het veelvuding optreden der Mosaickziekte bij Sumatratabak. (A preliminary statement showing the multeity manifested in mosaic disease of Sumatra tobacco.) Tijds. Nijverheid \& Landvouw in NedIndië 67:225-237, 1903.

Bemerkung zur Woods' schem Theorie über die Mosaikrankheit des Tabaks. (Remarks on Woods' theory upon the mosaic disease of tobacco.) Bull. Inst. Bot. Buitenzorg 17: 1-9, 1903.

Het Rupsen-Toeken by tabak in verband met het later optreden der mosaick-ziekte. Teysmannia 16:632-638, 1903.

(On the spreading of mosaic disease (Calico) on a tobacco field.) Inst. Bot. Buitenzorg Bull. 17:10-16, 1903.

Over de verspeding der mosaickziekte op een tabaksveld. (On the spreading of mosaic disease on a tobacco field.) Handl. v. h. 7 Vlamsch Natuur en Geneeskunding Congress p. 1-14, 1903.

Die verbreitung der Mosaikkrankheit infolge der Behandlug des Tabaks. Centralbl. f. Bakt. 11 : 405-408, 1904.

Over den aard der Cesmettelykheid der Mozaickziekte der Tabaksplant. Handl. v. h. 8. Vlaamsche Natuur en Geneeskundink Congress 3:45-50, 1904. 
Infloed van het verspenen van tabaks bibit. Korte Berichten Int's Lands. Plantentuin. Teymannia 15:58-64, 1904.

Neue Theorie zur Atiologie die Mosaikkrankeit des Tabaks. Ber. D. Bot. Ges. 23(8) : 415-418, 1905.

A brief, preliminary paper giving the author's theory of 'physiological catalytic"' action. Believes the mosaic of tobacco is due to a toxin which develops in the cells of the plant.

- Untersuchugen und Betrachtungen über die Mosaikkrankheit der Tabakspflanze. Ztschr. Pflanzenkrank. 15(5):257-311, 1905.

A more extensive paper than the proceeding which reviews the subject to date and reaffirming his opinion that the disease is due to an unorganized ferment which is different from an enzyme.

Onderzoekingen en Ceschouwingen over de mosaikziekte der tabaksplant. (Investigations and considerations on the mosaic disease of the tobaceo plant.) Amsterdam 1906.

Beschaduwing als prophylaxis tegen de Mosaikziekte der Tabak. Mededeel. Dept. Landbouw. 3:62-68, 1907.

Die Verbreitung der Mosaikkrankheit infolge der Behandlung des Tabaks. Centralbl. f. Bakt. 2(11) : 405-408, 1908.

\section{Hungerford, Cha[rle]s W[illiam]}

Leaf-roll, mosaic and certain other related diseases in Idaho. Phytopathology 12(3) : 133-139, 1922.

This is a discussion of several virus diseases in Idaho, giving their history

Preliminary results of experiments with leaf-roll and mosaic in Idaho. Phytopathology (Abstract) 13(11): 511-512, 1923.

Western yellow tomato blight. Idaho Agric. Expt. Sta. Bull. 131, 71 p., 1923.

\section{-_-_._. \& Ralder, John Milford}

Mosaic and leaf-roll of potatoes in Idaho. Phytopathology (Abstract) 14(2) : 123, 1924. 
\& Dana, B[liss] F.

Witches' broom of potatoes in the Northwest. Phytopathology $14(8): 372-383,1924$.

A very complete discussion of the symptoms and nature of the disease based on observations and studies.

A new virus disease of Delphinium in Idaho. U.S.D.A. Plant Disease Reporter 17(1): 5, 1933.

\section{Huntley, F[red] A.}

Tomato culture. Idaho Agric. Expt. Sta. Bull. 34:108-117, 1902.

\section{Husain, M. Afzal}

Leaf curl in cotton. Nature 126(3190):958, 1930.

Short note about the occurrence of this disease in Punjab, India.

Leaf-curl in cotton and other plants. Nature, $130(3278): 312$, 1932.

The disease is common in potato, tomato and pepper (C. annuum.)

\section{Hutchins, L[ee] IVI[ilo]}

Peach orchards in Georgia menanced by phony disease. U. S. D. A. Yearbook, 1927:499-503, 1928.

A brief statement concerning the spread of the disease and its effects on the fruit.

The cause and contagious nature of the phony disease of the peach. Proc. Ann. Meet. Georgia State Hort. Soc. 53:2532, 1929.

Popular discussion.

Phony disease of the peach. Phytopathology (Abstract) 19 (1) : 107, 1929.

The phony disease of the peach. Mississippi State Plant Board Quart. Bull. 10(1) : 1-11, 1930.

A review of the history of the disease and its geographical distribution in Southern United States.

The phony disease of the peach. Journ. Econ. Ent. 23(3): 555-562, 1930. (Rev. Path. Vég. 17(8-9) : 384, 1930.) 
Peach mosaic; a new virus disease. Science n.s. 76 (1962): 123, 1932. (Phytopathology (Abstract) 23(1):17, 1933.) The first record of this new disease.

Identification and control of the phony disease of the peach. Georgia Office of the State Entom. Bull. 78, 55 p., 1933.

Extensive considerations about the disease in the State of Georgia. Description of the disease and damages caused, methods for identifications of the malady. The author states also that circunstantial evidence points to the peach borer Aegeria exitiosa as the insect vector of the virus. As the only method of control he recommends the destruction of infested trees.

\section{Hutson, J. C., \& IIalcom, Park}

Investigation of the bunchy top disease of plantains in Ceylon. Trop. Agr. (Ceylon) 75(3):129-140, 1930.

A review and description of this disease and experiments demon. strating that it is carried by Pentalonia nigronervosa. Root disease is not necessarily associated with bunchy top. Eradication is the most satisfactory method of control.

Iachevskï, A.

Kratkü obzor sovremennogo sostoianüa uchenüa o vyrozhdenï $\mathrm{u}$ rastenii. (A brief review of the present status of the study of degeneration in plants.) Materialy po mikologü i Fitopatologii $7(1)$ : 195-207, 1928.

\section{Ichitkawa, Nobujiro}

On the similarity of mulberry dwarfs and peach yellows in regard to their symptoms and eause. Bot. Mag. Tokyo, 9: 82-89, 1896.

\section{Ikeno, J.}

Studies über eimen eigentümlichen Fall der infektiösen Buntblättrigheit bei Capsicum annuum. Ztschr. Wis. Biol. E. Planta $11(2)$ : 359-367, 1930.

\section{Illingworth, J[ames] $\mathbf{F}$ [ranklin]}

Yellow spot of pineapple in Hawaii. Phytopathology 21(9): 865-880, 1931.

A new disease which is very important. It is carried by thrips.

Preliminary report on evidence that mealy bugs are an important factor in pineapple wilt. Journ. Econ. Ent. 24(4): 877-889, 1931. 
Ito, $\mathbf{S}$.

Summary of four years' work on the subject in Hawaii. The author presents evidence that pineapple wilt is transmitted by Pseudococcus brevipes, Ckll. a mealy bug which infects the pineapple in Hawaii. He recommends biological control.

(Diseases of potatoes with special reference to the virus diseases.) Govern. Hokkaido Bur. Indust. Agric. Bull. 32, 24 p., 1930.

\section{Iwanowski, $\mathrm{D}$ [mitri Josiphowitachz Valerian Viktorowitch]}

Rjabucha bolesen tabaka, eja pritschini i sielstwo borbi snejen (Die Pokenkrankheit der Tabaspflanze.) (The spot disease of tobacco plant:) Mem. Acad. Imp. Sci. St. Petersburg 7 (37) : 23, 1890 .

Ueber zurie krankheiten der tabakspflanze. (About two tobacco diseases.) Bull. de l'Acad. Inspér d. Sci. St. Petersburg 2 (3) : 67-70, 1892. (Abstracted in Beihefte Botanisches Centb. Jahrg. 3:266-268, 1893.)

Ueber die mosaikkrankheit der tabakspflanze. (About the mosaic disease of tobacco plant.) Centrabl. f. Bakt. 5(8):250254, 1899 .

Ueber die mosaikkrankheit der tabakspflanze. (About mosaic disease of tobaceo plant.) Centrabl. f. Bakt. 7: 148, 1901.

Die mosaik und pockenkrankheit der tabakspflanze. (Mosaic and the spot disease of tobaceo plant.) Ztschr. f. Pfanzenkh. $12(4)$ : 202-203, 1902.

Discusses differences between mosaikkrankheit and pockenkrankheit.

Ueber die mosaikkrankheit der tabakspflanze. (About the mosaic disease of the tobaceo plant.) Ztschr. Pflanzendrank. 13(1) : 1-14, 1903. (Bot. Centbl. 40, 1903.)

An extensive study of the disease with references to the work of previous workers. He believed the disease to be due to bacteria but failed to isolate an organism. He gives the results of inoculation experiments, filtering and observations.

Iyengar, A. V. V.

Contributions to the study of spike disease of sandal (Santalum album Linn.) II \& III. Journ. Indian Inst. Sci. 11A(9) : 97109, 1928. 
Contributions to the study of spike disease of sandal. (Santalum album, Linn.) Part X. Seasonal Studies on healthy and partially spiked trees. Journ. Indian. Inst. Sci. 12A(20):295305, 1929.

This paper gives the results of chemical analyses of the leaves made during the period of the development of the disease. Also of healthy leaves during the same period.

\section{Iyengar, B. Narasimha}

Spike disease of sandal. Mysore Dept. Agric. Ann. Rpt. 1922 $23: 10-12,1923$.

A brief record of studies on sandal wood.

\section{Jackson, A[lbert] $\mathrm{B}$ [ruce]}

A possible cause of spike in sandal. Indian Forester 45:635, 1919 .

Suggests that the disease may be caused by excessive parasitism of sandal on sandal.

Jackson H[erbert] S[pencer] \& Osner, G[eorgie] $\mathbf{A}$ [din]

Potato diseases in Indiana. Indiana Agric. Expt. Sta. (Perdue Univ.) Circ. 71, 16 p., 1917.

\section{Jackson, L. W. R., \& Hartley, Carl}

Transmissibility of the brooming disease of Black Locust. Phytopathology 23(1): 83-90, 1933.

Detailed report of the authors in the transmissibility of brooming disease of Robina pseudacacia. The disease is considered to be caused by a virus. Attempts to transmit it by budding gave negative results, although it was successfully transmitted by grafting.

\section{Jaczwski, $\mathbf{A}$ [rthur] L[ouis]}

(Degeneration diseases of the potato according to the results of the investigations made in 1924.) Central Potato Cooperation Union, Moseow, 65 p., 1925.

(Witches' broom of potato.) Materials for Mycology \& Phytopathology 5(2): 117-128, 1926.

Mesures practiques contre les maladies de la dégénérescence. (Practical measures against the degeneration diseases.) Dé. fense des plantes, 4(1):62-77, 1927.

(A summary of the present status of the study of degeneration diseases in plants.) Mat. Mycol. \& Phytopath., Leningrad, $7: 195-207,1928$. 
(Ring spot of tobaceo leaves.) Ann. Inst. Expt. Agron. (Leningrad) 6:61-65, 1928. (Rev. Appl. Mycol. 9:347, 1930.)

A report of a ring spot which the author believes to be the same as the ring spot in the United States.

\section{Jagger, I[van] C[laude]}

Experiments with the cucumber mosaic disease. Phytopathology 6(2) : 148-151, 1916.

Gives the results of inoculation experiments and demonstrates that the disease is carried by Aphis gossypii Glover.

Two transmissible mosaic diseases of cucumber. Phytopathology (Abstract) 7(1):61, 1917.

Host of the white pickle mosaic disease of cucumber. Phytopathology 8(1): 32-33, 1918.

A brief note giving the hosts for this virus.

Mosaic disease of cucurbits. Phytopathology (Abstract) 8(2) : 74-75, 1918.

Transmissible mosaic disease of lettuce. Journ. Agric. Res. 20 (10) : 737-740, 1921.

Symptoms and transmission experiments.

Jaguenaud, G.

Recherches sur la dégénérescence de la pomme de terre. (Researches on the degeneration of the potato.) Compt. Rend. Acad. Agr. France. 17(10) : 318-322, 1931.

(Th influence of the soil and its position on the degeneration of th potato.) Compt. Rend. Acad. Sci. 193:582, 1931.

Janse, J. MI.

Proeve eener verklaring van sereh verschijn selen. Meded uit's Lands Plantentuin te Buitenzorg, 8:1-39, 1891.

\section{Janssen, J. J.}

Invloed der bemesting op de gezondheid van de aardappel. (Influence of manuring on the health of the potato.) Tijdschr. Plantenziek. 35(5): 119-151, 1929.

This paper is devoted primary to the relation of soils and fertilizers to the virus diseases. 
194 THE JOURNAL OF AGRICULTURE OF THE UNIVERSITY OF P. $\mathrm{R}$.

\section{Jarrett, Phyllis H.}

Streak. - a virus disease of tomatoes. Ann. Appl. Biol. 17(2) : 248-259, 1930.

A comparison of this disease with a disease produced by inoculation with a mixture of juice from mosaic potato and mosaic tobacco plants. The author concludes that the glass house streak of tomato does not contain potato virus. Tobaceo mosaic and tomato streak appear to be due to a single virus.

The role of Thrips tabaci Lindeman in the transmission of virus diseases of tomato. Ann. Appl. Biol. 17(3):444-451, 1930.

After experimentation to show the role of Thrips tabaci Lindeman in the transmission of virus disease of tomato, it is concluded that it does not transmit the disease under all conditions.

\section{Jehle, $\mathbf{R}$ [obert] $\mathbf{A}$ [ndrew]}

Disasterous effects of mosaic on the MeCormick potato. Maryland Agric. Expt. Sta. Bull. 282 : 215-219, 1926.

A popular paper giving valuable data.

\section{Jensen, $\mathrm{H}$ [jalmer]}

Ueber die Bekampfung der Mosaikkrankheit der Tabakpflanze. (About the control of mosaic disease of the tobacco plant.) Contrabl. f. Bakt. 15: 440-445, 1906. , et al.

(Pathology and physiology of tabaceo in the Crown Lands.) Proefstat. Vorsteland, Tabak (Dutch East Indies). Meded. 5: 7-78, 122-130, 137, 197-198, 1913.

A record of the work of Raciborski and Jensen for the years 18981911.

Eenige onderzeekingen over mozaikziekte bij de tabac. (Some investigations on mosaic disease of tobacco.) Meded. Proefstat. Vorsteland. Tabak 33:59-66, 1918.

The author reports that diseased plants may produce new foliage which does not show symptoms but this is not a proof that the plants have recovered.

\section{Jensen, James $\mathbf{H}$.}

Leaf enation resulting from tobacco mosaic infection in certain species of Nicotiana L. Contr. Boyce Thompson Inst. 5(1): 129-142, 1933.

This paper is the result of a study of outgrowths on the lower side of leaves of mosaic Nicotiana paniculata and $N$. tomentosa. They did 
not occur in plants shaded from direct sun light. Similar outgrowth occur occasionally on $N$. tabacum var. angustifolia grown from eutting but not on plants grown from the seeds. These outgrowths sometimes produce palisade cells on the lower surface.

Isolation of yellow-mosaic viruses from plants infected with tobacco mosaic. Phytopathology 23(12) : 964-974, 1933.

The author gives his observations in experimental work and concludes that viruses of yellow mosaic arise during multiplication of tobacco-mosaic virus in infected plants.

\section{Jiménez Núñez, F.}

Cultivo de la caña de azúcar. (Sugar cane cultivation.) Centro Nal. de Agric. (Argentina) Bull. 6:3-24, 1930.

\section{Jivanna Rao, P. S.}

The cause of spike in sandal. (Santalum album) Indian For. 46 : 469-487, 1920. (Bot. Abs. $7: 173,1921$.)

The physiological anatomy of the spiked leaf in sandal (Santalum Album L.) Indian For. 49(9):351-360, 1921. (Bot. Abs. $10: 285$, 1922.)

The cause of spike disease in sandal (Santalum album L.) Indian Sci. Congr. Proc. $11: 149,1924$.

The virus tleory in relation to spike disease of sandal. Imp. Bot. Confr. (London.) p. 357-359, 1924.

\section{Jochems, S[arah] C[amelia] J[ohannes]}

Ziekten van Deli-tabak. (Diseases of deli-tobacco.) Meded.

Deli Proefstat. Medan Sumatra 2 ser. 43, 39 p., 1926.

A popular discussion of many diseases, including virus diseases. Exceptionally well illustrated.

Eene niewe virusziekte van Deli-tabak, de Rotterdam B-ziekte. (A new virus disease in Deli-tobacco, the Rotterdam B-disease.) Meded. Deli Proefstat. Medam Sumatra Bull. 26, 26 p., 1928.

A record of a new virus disease of tobaceo under the name of "Rotterdam B-Disease".

Twee nieuwe virusziekten bij Deli-Tabak (Ringvlekziekte en nerfstreep.) (Two new virus diseases of Deli Tobacco (ring- 
spot disease and vein streak.) Deli Proefstat. te Medam, Sumatra Bull. 30, 24 p., 1930.

Description of these two diseases and record of inoculation experiments.

Jodidi, S[amuel] L[eo], Kellog, E[dward] H., \& True, Rodney $\mathrm{H}$ [oward]

Nitrogen metabolism in normal and blighted spinach. Journ. Agric. Res. 15 : 385-408, 1918.

The diseased plants have a low nitrogen content and a high ammonia content. The authors record a number of differences in chemical content between diseased and healthy plants.

IIoulton, S[tarley] C[heney,] \& IMackley, K. S.

Mosaic disease of spinach as characterized by its nitrogen constituents. Journ. Amer. Chem. Soc. 42:1061-1070, 1920.

A mosaic disease of cabbage as revealed by its nitrogen constituents. Journ. Amer. Chem. Soc. 42:1883-1893, 1920. (Science n. s. 52 (1355): 588, 1920.)

Joest, Ernest

Ueberkannte Ifektionsstoffe. Centralbl. f. Bak. 31:365, 1902. Joglar Rodríguez, F[rancisco]

"El mosaico" enfermedad del tabaco. ("The mosaic" disease of tobaceo.) Rev. Agric. Puerto Rico, 25(10): 150, 176, 1930. Popular discussion and deseription.

Johnson, A[aron] G[uy,] IIc Kinney, H[arold] $\mathrm{H}[$ all, $\mathbf{W}$ Webb, Robert W[illiam,] Leighty, Clyde E[vert]

The rosette disease and its control. U.S.D.A. Farmers' Bull. 1414, 10 p., 1924.

Popular.

\section{Johnson B[urt] Parker, \& Duggar B[enjamin] MI inge]}

Stomatal infection with the virus of tabacco mosaic. Phytopathology (Abstract) 20(1):141-142, 1930.

Concentration of the virus of the mosaic of tobacco. Amer. Journ. Bot. 21(1) : 42-53, 1934.

The author precipitated material containing virus with a direct 110 volt current and with several salts. Some carbons can be used to clarify the juice and leave the tobaceo in suspension. The author describes a method for preparing highly concentrated suspensions. There is a difference in the protein reaction of juices from healthy and mosaic plants. The positive protein reaction may be due to products associated with the virus. 


\section{Johnson, E[dward] M[arshall]}

Virus diseases of tobacco in Kentucky. Kentucky Agric. Expt. Sta. Bull. 306 : 289-415, 1930.

A ringspot-like virus disease of red clover. Phytopathology $23(9)$ : 746-747, 1933.

Report and description of a clover disease which shows virus like symptoms.

\section{Johnson G[eorge] W[illiam]}

The tomato, its culture, uses and history. Gard. Monthly, Vol. I, 1847.

\section{Johnson, James}

Diseases of tobaceo. Wisconsin Agric. Expt. Sta. Bull. 327, 27 p., 1914.

The relation of air temperature to certain plant diseases. Phytopathology 11(11) : 446-458, 1921.

Experimental evidence relating to the nature of the mosaic virus. Phytopathology (Abstract) 12(1):52, 1922.

The relation of air temperature to the mosaic disease of potatoes and other plants. Phytopathology 12(9) : 438-440, 1922.

The optimum temperature lies between 14 and $18^{\circ} \mathrm{C}$. The symptoms disappear with temperature above $20^{\circ} \mathrm{C}$.

\section{\& IMulvania MI[aurice]}

A new method of obtaining mosaic "virus". Science n. s. 60 (1540) : 19, 1924.

The extraction of the juice by hydraulic pressure.

A virus from potato transmissible to tobacco. Phytopathology (Abstract) 15(1) : 46-47, 1925.

The transmission of viruses from apparently healthy potatoes.

Wisconsin Agric. Expt. Sta. Res. Bull. 63, 12 p., 1925.

This paper gives the results of experiments which tend "to show that at least two different viruses are commonly, if not universally, present in most standard varieties of potatoes".

Mosaic disease on different hosts. Phytopathology 16(2) :141149, 1926. 
The author gives evidence that the mosaic of tobaceo due to five viruses which ean be differentiated by the reaction of other hosts when inoculated with them. They are: 1-ordinary tobacco mosaic, 2-cucumber mosaic, 3-petunia mosaic, 4-speckled tobaceo mosaic, and 5 -mild tobaceo mosaic.

The attenuation of plant viruses and the inactivating influence of oxygen. Science 64(1652): 210, 1926.

The virus of tobacco mosaic may be attenuated by growing the host at 35 to $37^{\circ} \mathrm{C}$. The action is more rapid in sandy than in clay soils.

New virus diseases of tobaceo and related plants. Phytopathology (Abstract) 16(1):66, 1926.

A record but no description.

Some points of view on the plant virus problem. Phytopathology 16(10) : 745-751, 1926.

The author emphasizes the need of greater knowledge of the specific properties of the viruses.

The classification of plant viruses. Wisconsin Agric. Expt. Sta. Res. Bull. 76, 16 p., 1927.

This paper gives the results of extensive experimental work from which the author describes ten viruses. The descriptions are based on the reaction of several host plants, resistance to aging, heat and chemicals.

The properties and behavior of potato rugose mosaic. Phytopathology (Abstract) 18(1) : 115, 1928.

Further studies on the attenuation of plant viruses. Phytopathology (Abstract) 18(1):156, 1928.

The classification of certain virus diseases of the potato. Wis conson Agric. Expt. Sta. Res. Bull. 87, 24., 1929.

This paper gives the results of the study of several virus diseases and includes transmission, aging in vitro, thermal death-point, tolerance, influence of chemicals, varietal susceptibility and symptoms which are variable.

\section{\& Butler Ogden, W[illiam]}

The overwinter of the tobacco mosaic virus. Wisconsin Agric. Expt. Sta. Res. Bull. 95, 25 p., 1929. (Rev. Appl. Mycol. 9 (3) : 207, 1930.)

This paper gives the results of extensive field experiments to determine the relative importance of various methods of overwintering. 


\section{\& Hoggan, Ismé A [ldyth]}

The challenge of plant virus differentiation and classification.

Fifth Int. Bot. Congr. Cambridge 1930:379-380, 1930. (Science $73(1880)$ : 29-32, 1931.) , \&

"Katahdin" a new variety of mosaic resistant potatoes. Science n. s. Suppl. 75(1938) : 12, 1932.

\section{\& Grant, Theodore J.}

The properties of plant viruses from different host species. Phytopathology 22(9): 741-757, 1932.

"The thermal death points, resistance to aging in vitro dilution tolerance, and the resistance to certain chemicals of the viruses of ordinary tobaceo mosaic, cucumber mosaic, tobaceo ring-spot, and tobacco spot necrosis (potato-rugose mosaic) have been compared in extracts from several species of host plants. The experimental results show that the host species in which the viruses developed did not radically influence the constancy of the properties of each virus. Some minor influences were noted that are hardly to be regarded as of sufficient magnitude to be of actual significance.

The contentions that have previously been made in the literature that plant viruses may be fundamentally changed by the host plant affected and that the properties of viruses cannot be adequately studied in a comparative way with the ordinary technique are consequently not supported by the results secured. It is believed that the properties of artificially transmissible plant viruses offer one of the most convenient and reliable criteria for their isolation, differentiation and classification.

Cucumber mosaic on tobaceo in Wisconsin. Phytopathology (Abstract) 23(3): 311, 1933.

Report of field observations. The author points out the occurrence of cucumber mosaic in an epidemic form on tobaceo. Appears on the basis of past field records to be unusual.

\section{Johnston, John R[obert,] \& Stevenson, John A[lbert]}

Fungi and diseases of sugar cane in Porto Rico. Journ. Dept. Agric. Porto Rico 1(4) : 228-233, 1917.

Brief notes: Early account of the occurrence of mosaic disease of sugar cane (called mottling) in Puerto Rico.

\section{K[eith] Nowell, W[illiam] \& Stevenson, John A[lbert]}

Diseases of sugar cane in tropical and subtropical America, especially the West Indies. West Indies Bull. 16(4) :298300, 1918.

Brief notes on sereh and mosaic disease of sugar cane, the first in Java and the second in Puerto Rico. Deseription of both diseases. 
The new cane disease in Cuba. The Louisiana Planter \& Sugar Mfg. 63(6) : 43, 1919.

The author declares that at least the disease is present in three provinces. Quarantine measures are recommended. The author discusses also the history of the disease in other countries.

La enfermedad "Mosaico" de la caña de azúcar. (The disease "mosaic" of sugar cane.) Sección de Sanidad Vegetal, Cuba, Circ. No. 6, 11 p., 1919.

The author gives popular discussion and recommendations.

The mosaic disease of sugar cane in 1923. (A discussion of. the problem to data.) United Fruit Co., Agric. Res. Dept. Pamphet, 35 p., 1923. (Louisiana Planter 73(1):10-11, (2) 30-32, (3)49-52, 1924. The Int. Sugar Journ. 26:469-473, 1924. A Rev. by C. A. Barber in Rev. Agric., Porto Rico 13: 265-272, 1924.)

A popular but very comprehensive discussion of this disease.

Control of sugar cane mosaic. Louisiana Planter 74(10): 190 191, 1925.

The disease spreads slowly in Cuba. Control by inspection and roguing is recommended.

Joly, R. L.

Les conséquences de la mosaïque du manioc. (The effects of Cassava mosaic.) Rev. de Bot. Appl. et d'Agrid. Trop. 11(114) : 99-104, 1931.

On Manihot utilissima and $\mathbb{M}$. dulcis. The former is the more resistant.

Jones, F[red] R[euel,] \& Granovsky, A[lexander] A[nastacievitch] Yellowing of alfalfa caused by leafhoppers. Phytopathology (Abstract) 17(1): 39, 1927.

Jones, G. H[oward,] \& Mason, T. G.

On two obscure diseases of cotton. Ann. Bot. 40 :(160) : 759-771, 1926.

Description of two diseases of cotton in Nigeria, "leaf curl" and "leaf roll". "Leaf curl" is a virus disease, while "leaf roll" is not infectious and is eaused by excessive soil humidity.

\section{Jones, $\mathbf{L}[$ eon] $\mathbf{K}$ [ilby]}

The effect and the rate of spread of "streak" on greenhouse tomatoes. Phytopathology 20(10): 851, 1930. 
Virus diseases of raspberry in Washington. Washington State Hort. Assoc. Proc. 26: 196-199, 1930.

The mosaic disease of beets. Washington Agric. Expt. Sta. Bull. 250, 16 p., 1931.

The author diseusses briefly the general aspects of the disease, coneluding that it is not in the soil and is transmitted by the mother beets. Curly-top is also present in Skajit County. Mosaic disease is also reported in garden beets, sugar beets, mangels and spinach.

A new method of inoculating with viruses. Phytopathology (Abstract) 22(12) : 998-999, 1932.

The sources of the viruses that causes streak of tomato. Phytopathology (Abstract) 22(12):999, 1932.

Caused by a combination of latent potato virus and common tobaceo mosaic.

\section{Anderson, E. J., \& Burnett, G[rover]}

(The latent virus of potatoes.) Phytopath. Zeitschr. 7(1): 93-115, 1934.

\section{Jones, Lewis R[alph] \& Shear, C[ornelius] L[ott]}

False blossom of cranberries. Wisconsin Agric. Expt. Sta. Bull. 240, 1914.

A report upon false blossom and other cranberry maladies. Wisconsin State Cranberry Growers' Ass'n Ann. Rpt. 27: 13-14, 1914.

Soil temperature as a factor in phytopathology. Plant World 20 : 229-237, 1917.

\section{Miller, IM[aude] \& Bailey E[rnest]}

Frost necrosis of potato tuber. Wisconsin Agric. Expt. Sta. Res. Bull. 46, 1919.

Experimental work on the relation of soil temperature to diseases in plants. Wisconsin Acad. Sci. Arts \& Letters. Trans. 20: 433-459, 1922.

\section{Johnson, James \& Dickson, J[ames] G[eere]}

Wisconsin studies upon the relation of soil temperature to plant diseases. Wisconsin Agric. Expt. Sta. Res. Bull. 71, 1926. 


\section{\& Riker, Regina [Emma] S[tockhausen]}

Progress with the control of aster wilt yellows. Phytopathology (Abstract) 19(1): 101, 1929.

, \&

Further progress with the control of aster wilt and yellows. Phytopathology (Abstract) 20(1): 129, 1930.

Wisconsin studies on aster diseases and their control. Wisconsin Agric. Expt. Sta. Res. Bull. 111, 39 p., 1931.

This publication includes a very complete discussion of aster yellows and its control.

The oldest known plant virus disease. Science. n.s. 75(2052) : $385,1934$.

This is a review of M. B. Me Kay and M. F. Werner's Historical sketch of tulip mosaic or "breaking",

\section{Jones, Philip II[allory]}

A Mycetozoan found in tobaceo plants with mosaic-like symptoms. Phytopathology (Abstract) 16(1) : 67, 1926.

Structure and cultural history of a mycetozoan found in tobacco plants with mosaic-like symptoms. Bot. Gaz. 81(4) : 446-459, 1926.

The author gives results of studies which lead him to believe that tobaceo mosaic is due to an organism which he describes under the name of Plasmodiophora tabaci.

Parasite Calkinsi on Plasmodiophora tabaci and its possible etiological role in tobacco mosaic. Arch. Protistenk. 62(2-3): 307-312, 1928.

The author describes an unidentified parasite which he believes to be the cause of the mosaic.

\section{Jones, Walter, \& Rawlins, T[homas] E[lsworth]}

Influence of spindle-tuber disease on the physiology of the potato tuber. Phytopathology (Abstract) 19(12): 1137, 1929.

\section{Jordi, Ernst}

(Report on plant diseases.) Jahresber Landw. Schule Riits, 1909-10: 108-114, 1910. 
Die Blattrollkrankheit der Kartoffel. (The leaf roll disease of potatoes.) Jabresher. d. Landw. Shule Rütti-zollikofen 191618. Anzew Bot. 1:216, 1919.

Die Blattrollkrankheiten der Kartoffel. (Leafroll diseases of potato.) Mitteil. Naturf. Ges. Bern. (Abstract) $1922: 36-37$, 1923.

\section{Jorstad, I [van]}

Beretning om plant ensykdommer i land og havebruket 1920-23. II Frikttraer og haervekster. (Report on plant diseases in agriculture and horticulture in 1920-23. II Fruit trees and small fruits.) Cristiania Grondahl and Sons Boktrykkeri, 73 p., 1923.

A record of cultivated raspberry mosaic.

\section{Jorgensen, C. A., \& Nielsen, O[laf]}

Kartoffelsorter og Kartoffelsygdomme. Orienterende undersgelser. (Potato varieties and potato diseases. Preliminary investigations.) Tidsskr. for Planteave 39(2):295-315, 1933.

A detailed and tabulated account is given of the authors' investigations in Denmark for five years, on the reaction of some standard va. rieties to late leaf roll, mosaic and other diseases.

\section{Kaiser, $\mathbf{P}$.}

Die Blattrollkrankheit der Kartoffel. (The leaf roll disease of potato.) Prakt. Ratgeb. Obstr-u Gartenbau 37:387-388, 1922.

\section{Kamerling, $\mathbf{Z}[\mathrm{eno}]$}

Onderzoekingen over onvodoenden groei ontijdig afsterven van rilt als gevlg van wortelziekten. Meded. van het Proefstation Suikerriet West Java No 48, 1900.

De gele-strepensiekten der bladeren. (The yellow stripe disease of the leaves. ). Proefstation Suikerriet West Java "Kakok" to Pekalongan, Verslag. 1902:76-81, 1903.

\section{Karunakara Menon, C.}

Does fire, or exposure of trees growing under shade, or damage to hosts lead to spike disease in sandal? Indian For. 45: 498-500, 1919. 


\section{Kasai, Mikio}

(Observations and experiments on the leafroll disease of the Irish potato in Japan.) Ber. Ohara Inst. Landw. Forsch, 2 (1) : 47-77, 1921 .

Gives a history of the disease in Japan.

(Mosaic disease of cucumber.) Agric. Lec. 5:42-71, 1923.

Investigations on the Nelson's Bodies as observed in the leafroll, mosaic and healthy plants. Ber. des Ohara Inst. Landw. Forsch. in Kuraschiki, Japan. (English trans.) 2(4) :443-461, 1924.

The author gives a review of the literature and the results of his studies on bodies found in the phloem tissues. He believes these bodies to be disentigrating nuclei.

(Studies on the potato leafroll.) Japanese Dept. Agric. \& Forsch. Bur. Agric. Mycol. \& Entom. Bull. 17, 70 p., 1926.

\section{Kellerman, $\mathbf{K}$ [arl] $\mathbf{F}$ [rederic]}

Leaf-cut or tomosis of cotton seedlings. U. S. D. A. Ann. Rpt. p. 159, 1918. (Br. of Plant Indust. Rpt. for 1918, p. 25.)

Phony disease of peach. U. S. D. A. Br. Plant Indst. Plant Dis. Rept. 14(17) : 171, 1930.

A record of occurrence of this disease.

Kelly, N. L.

Bureau of Sugar Experiment Station. Assistant Plant Pathologist, Report. Australia Sugar Journ. 18(3) : 171, 172, 1926. (Rev. Appl. Mycol. 5:696-697, 1926. Queensland Agric. Journ. 26(2): 115, 1926.)

Contains a brief discussion of mosaic of sugar cane and other diseases.

Assistant Pathologist Report. The Australian Sugar Journ. 18 (5) : 277-278, 1926.

Mosaic disease in cane. Sugar 18(3):171-172, 1926. (Queensland Agric. Journ. 25(6):498, 499, 1926.)

Bureau of Sugar Experiment Station. Cane pests and diseases. Queensland Agric. Journ. 26(2): 115, 1926. 
(ane pests and diseases. Queensland Agric. Journ. 27: (2) : 82, 83, 96, 98, 1927. (Rev. Appl. Mycol. 6: 375, 376, 1927.)

\section{Kendrick, James B[lair,] \& Gardner IM[ax] W[illiam]}

Soybean mosaic seed transmission and effect of yield. Journ. Agric. Res. 27(2) : 91-98, 1924.

The disease is transmitted through the seed. It reduces the yield of seed. The seed from diseased plants do not germinate well.

\section{Kerling, L[ouise] C[atharina] P[etronells]}

Microseopich onderzoek van pseudonet-necrose en Kringerigheid van de Aardappel, (Microscopic investigations of pseudo-net necrosis and "Krigeriheid" of the potato.) Meded. Landbouwhooschool Wageningen. 33(10):17, 1929. (Rev. Appl. Mycol. 9:477. 1930.)

The first disease is transmitted in the seed. The second occurs on certain soils. The microseopic characters are very similar.

Microscopic investigations of pseudonetnecrosis and Krigerigheid of the potato. Phytopathology (Abstract) 20(1):138, 1930.

The anatomy of the "Kroepoek-diseased" leaf of Nicotiana tabacum and of Zinnia elegans. Phytopathology 23(2): 175190, 1933.

A detailed description of the writer's observations in his anatomical studies on tobacco and zinnia leaves received from Java, which were affected by "common", and "transparent" types of "Kroepoek" (leaf curl).

\section{Keur, John Y.}

Seed transmission of the virus causing variegation of abutilon. Phytopathology (Abstract) 23(1):20; 1933.

Studies of transmission of the virus causing variegation in Abutilon thompsoni and $A$. mulleri in seedlings produced by crossing these two species.

Partial recovery and immunity of virus-diseased abutilon. Phytophathology (Abstract) 24(1) : 12-13, 1934.

\section{King, C[harlmers] J[ackson] \& Loomis, H[arold] Frederic}

Factors influencing the severity of the crazy-top disorder of cotton. U. S. D. A. Bull. 1484, 21 p., 1927. 


\section{Kinney, Addison}

Cane diseases in the Hawaiian Islands. The Planter \& Sugar Mfg. 76(10): 191-192, 1926. (Rev. Appl. Mycol. 5:518, 1926.)

Studies and estimate of losses due to mosaic.

\section{Krickner, Emil Otto, Oskar von}

Die blattrollrankheit der kartoffeln. (The leafroll disease of potatoes.) Deutsche Landro Presesse 45 No. 14, 1919. (Ztschr. Pflanzenkranklr. $29: 54,1919$.

Discussion of symptoms of true potato leafroll and separating it from other diseases. Cause not found.

\section{Kirk, T[homas] W[illiam]}

Potato diseases. New. Zeal. Dept. Agric. Ann. Rpt. 13: 346-363, 1905.

\section{Kirkpatrick, T[homas] W[infrid]}

Preliminary note on leaf-crinkle of cotton in the Geriza area. Sudan. Bull. Ent. Res. 21(2) : 127-137, 1930.

Control experiments indicated that a white fly (Aleurodidae) is the vector. Experiments with Empoasca fascialis, gave negative results.

Leaf-curl in cotton. Nature 125(3157) : 672, 1930. (Rev. Appl. Mycol. 9: 590, 1930.)

A disease of long staple cotton in the Sudan region appears to be caused by a virus and is transmitted by a species of Aleurodidae.

Further studies of leaf-curl of cotton in the Sudan. Bull. Ent. Res. $22(3)$ : 323-363, 1931.

The author adopts the name "leaf-curl" which is manifested by symptoms of "leaf-crinkle" on some varieties of cotton and mosais on others. Crinkle is transmitted by white flies (Bemisia gossipiperda). It attacks Hibiscus esoulentus, H. cannabinus, H. sabdariffa and Altheae rosea.

\section{Kirschner, $\mathbf{R}$.}

Die Blattrollkrankheit des hopfens. (The leafroll disease of hops.) Biol. Generalis Vienna 5:225, 1929. (Abstract in Fortschr. der Landw. 6(21):699-700, 1929. Rev. Appl. Mycol. 9(2) : 131, 1930.)

The author believes that this disease is due to manure.

Klapp, E. L.

Ukologie und Abbau der Kartoffel. (Ecology and degeneration of the potato.) Pflanzenzucht. 8(9): 213-218, 1932. 
Brief discussion of the various hypotheses of the etiology of the virus diseases. Gives also considerations of the potato degeneration problems in relation to the ecology in German and full details of a system of experimentation.

Der Abban der Kartoffel als Folge von Leistungsiibers-pannungen. (Potato degeneration as a sequel to overtaxation of the productive eapacity.) Pflanzenbau Pflanzenschutz $u$. Pflanzenzucht. 10(4) : 129-146, (5) : 161-197, 1933.

Continuation of previous work and observations in which the author develops his theory of an ecological basis for potato degeneration.

\section{Klebahn, Henrich}

Ueber eine Krankhafte Veränderung der Anemone memorosa L. und über inen in den Drüsenhaaren derselben Pilz. Ber. D. Bot. Ges. 15: 527-536, 1897.

Virus Krankheiten. (Virus diseases.) Plant 6(1):43-63, 1923 .

Die Alloiophyllie des Anemone nemorosa und ihre vermutliche ursache. (Alloiophylly on Anemone nemorosa and its probable cause.) Planta Arch. Wiss. Bot. 1(4) : 419-440, 1926. (Ztschr. Wis. Biol. Abt. Ber. Deussche Bot. Gesellech 43(32)-(37), 1926.)

Reports the finding of bacteria-like bodies in the cells. The disease is transmitted through the soil.

Ueber viruskrankheit und Alloiophyllie. (mit Demostrationen.) (Virus diseases and alloiophylly.) Naturwissenschaften (Abstract.) $16(45-47)$ : 1002, 1928.

Auschluss an alloiophyllie und viruskrangheiten. Plants 5:49_ 73, 1928.

Experimentalle und cytologische untersuchungen im anschluss an alloiophyllie und viruskrankheiten. Ztschr. Wiss. Biol. Abt. E. Planta 6(1) : 40-95, 1928.

The author describes the symptoms of alloiophylly a disease of Anemone nemorosa. The disease was produced by inoculation with filtered juice. The author also made a study of cell inclusions which be classified as follows; 1-amoeboid bodies; 2-thread-like bundles, and 3-striated bodies, all of which are founded in the phloem of both healthy and diseased plants; 4-trypanoplasts which are found in both healthy and mosaic potato and A. thompsoni. 
On scolecosomes and on similar bodies in mosaic diseased plants. Proc. Int. Congr. Plant Sci. (Ithaca, N. Y.) 1929: 1243-1248, 1929.

When Anemona ranunculoides and A. tripolia were inoculated with juice from $A$. nemorosa, scolecosomes were produced. Similar bodies were found in several other plants infected with virus diseases.

Fortsetzung der experimentallen Untersuchungen uber alloiophyllie und Viruskrankheiten. Phytopathology Ztschr. 4(1):1-36, 1931.

Efforts to cultivate tobacco mosaic virus gave negative results. The precipitate in sealed tubes for one year gave positive results when inoculated into plants.

Klemm, IM. J.

Mosaikkrankheiten der kulturpflanzen. (Mosaic diseases of cultivated plants.) Ostenrop. Landw. Ztschr. 9(11): 1932.

\section{Knight, Thomas Andrew}

On the prevention of the disease called curl in the potato. Hort. Soc. (London) Trans. 2:64-67, 1819. (Munster Farmers' Mag. 4: 68, 1816.)

Knorr, $\mathbf{P}$.

(Diseases of potatoes and their control.) Arb. Forschungsinst. Kartoffelban 4: 68-75, 1920.

(Potato diseases and their control.) Arb. Forschunsinst. Kartoffelban 6:114-121, 1922.

\section{Knowlton, George F[ranklin]}

Beet leafhopper and curly-top situation in Utah. Utah. Agric. Expt. Sta. Circ. 65, 12 p., 1927. (Facts About Sugar 22(32) : $768,1927$.

The beet leafhopper in Utah. A study of its situation and the occurrence of curly-top. Utah. Agric. Expt. Sta. Bull. 205, 23 p., 1928. (Rev. Appl. Mycol. 9(1): 9, 1930.)

A popular discussion of the transmission of the curly top of the sugar beet by Eutettix tenella.

Studies on the morphology of the beet leafhopper Eutettix tenellus (Baker.) Utah Agric. Expt. Sta. Bull. 212, 24 p., 1929. 
Studies on the beet leafhopper (Eutettix tenellus) Proc. Utah. Acad. Sci. $7: 57-58,1930$.

The beet leafhopper in northern Utah. Eutettix tenellus.) Utah Agric. Expt. Sta. Bull. 23, 64 p., 1932.

This paper does not deal with virus diseases but is interesting because the insect is a vector of the curly-top of the sugar beet.

\section{Kobus, J[acob] D[erk] \& Bokma de Boer, B.}

Selecttie van het Suikerriet. (Selection of sugar cane.) Arc. voor de Java Suiker Indust. P. 289-319, 1902.

Studien uber die Ursache der Blattrollkrankheit der Kartoffel und uber die Moglichkeit der Uebertrangung dieser Krankheit durch das Saatgut und den Boden. (Studies on the cause of leafroll disease of potato and on the possibiitity of transmission of this disease by means of seed and soil.) Ztschr. Landw. Ver. Osterr. 14(5) : 759-805, 1911.

\section{Broz, O[tto]}

Bericht uber die van der K. K. Pflanzenschuzstation im Jałre 1911 durchgefuhrten Versuche zum studium der Blattrollkrankheit der Kartoffel. (Report on the K. K. Plant Protection Station in the year 1911, about the experiments conducted on the studies of leafroll diseases of the potato.) (Mitteilungen des Komitees um Studium der Blattrollkrankheit der Kartoffel, No. 5. (Memoir of the committee for the study of the leafroll disease of potato. No. 5.) Ztschr. fur Landw. Ver. Osterr. Jahrg. 15(3) 179-247, 1912.

\section{Kornauth, $\mathbf{K}[\operatorname{arl}]$ \& Broz, Otto}

Ueber Blattrollkrankheit der Kartoffel VI. (Leafroll disease of the potato VI.) Ztrchr. Landw. Ver. Osterr. 16(3): 140, 1923. (Bot. Centralbl. (Abstract) 123(8): 200, 1913.)

(Important potato disease.) Monattish. Landw. 6(7) : 211-214, 1913.

Ueber dei Blattrollkrankheit der Kartoffel. (Potato leafroll disease.) Wiener. Landw. 64(41) : 382-383, 1914. 
Ueber der Blattrollkrankheit der Kartoffel. (Leafroll disease of the potato.) Zrscht. Landw. Ver. Osterr. 17(5):270-300, 1914.

\section{Koch, Karl Lee}

The potato rugose mosaic complex. Science n.s. 73(901):615, 1931.

Report that the rugose mosaic of the potato is the same as spotnecrosis in tobaceo and is caused by a combination of two distinct viruses.

The nature of potato rugose mosaic. Phytopathology 23(4): 319-342, 1933.

A rather extensive report of the author's experiments, fully discussed and tabulated. He confirms the evidence that rugose mosaic of potato is due to a combined action of the mottle virus normally present in healthy potatoes with "veinbanding".

\section{Kock, G[ustav], \& Kornauth, K.}

Studien über die ursachen der Blattrollkrankheit der Kartoffel und über die Möglichkeit der Uebertragung dieser Krankheit durch das Sastgut und den Boden. Zeitschr. Land. Versuchsw. Oesterr 14: 759-805, 1911.

Unsere gegenwärtigen Kenntnisse über die Blattrollkrankheit. (Our present knowledge on the leaf roll disease.) Monat. Landw. 2:379-383, 1909.

\section{\& Kornauth, $\mathbf{K}$.}

Beiträge zum Studium der Blattrollkrankheit. (Contribution to the studies on leafroll disease.) Monat. Landw. 3:365$369,1910$.

Die Blattrollkrankheit der Kartoffel. (The leafroll disease of potato.) Zeitschr. Landw. Versuchsw. Oesterr. 14: 737, 1911.

Die Blattrollkrankheit der Kartoffel. (The leafroll disease of potato.) Wien Landw. Zeitg. 64:382-383, 1914.

\section{et al.}

Studien über die Blattrollkrankheit der Kartoffel. (Studies on the leaf roll disease of potatoes.) Zeitschr. Landw. Versuchsw Oesterr. 17:270-300, 1914. 
Masseanauless als Mittel gegen den Abban. (Mass selection as a remedy for degeneration.) Osterr. Erscht. fur Kartoffelban, p., 45-47, 1930.

Popular.

Die "Viruskrankheiten" der Kartoffel. (The virus disease of the potato.) Osterr. Zrster. für Kartoffelban No. 2, 3 p., 1927.

Keeslag, F. D.

Die Kartoffelarkenung in Holland. Mitt. Deustch. Landw. Geselch. 14(23) : 505-508, 1930.

Potato seed selection for the gradual elimination of virus disease.

\section{Kofoid, Charles A[twood], Severinin, H[enry] Herman P[aul,] \& Swezy Olive.}

Nelson's spiral bodies in tomato not protozoans. Phytopathology, 13(7) :330-331, 1923.

This paper gives the results of the studies of both normal and diseased plants. Protozoan-like bodies were found in both and it was demonstrated that they were not trypanosomas.

\section{Köhler, E[rich]}

Stellungnahme zum Problem for Kartoffelbans. Die Kartoffel $10: 159-160,1930$.

Allgemeines uber viruskrakheiten bei pflanzen. (General information on virus diseases of plants.) Angew. Bot. 14(4) : $334-348,1932$.

A general review of the subject.

Die Rolle der Viruskrankheiten beim Kartoffelabbau. (The role of the virus diseases in potato degeneration.) Angew. Bot. 15 (2) :122-131, 1933.

The author states that the most important virus disease of potato in Europe, without a doubt is leaf roll, followed by K. M. Smith's X and Y, Murphy's and McKay's A and Köhler R 77 and H19.

Untersuchugen über die Viruskrankheiten der Kartoffel. I Versuche mit Viren aus der Mosaikgruppe. (Investigations 
212 TIIE JOURNAL OF AGRICULTURE OF THE UNIVERSITY OF $P$. $\mathrm{R}$.

on the virus diseases of the potato. I Experiment with viruses of the mosaic group.) Phytopath. Zeitschr. 5(6) :567-591, 1933.

A detailed account of the author's studies on the nature of five viruses isolated in Germany from potatoes, designated as M 23, M 29, H 19, R 77 and GA. Tests of these viruses were made on various hosts. Results are given.

Viruskrankheiten au Tomaten und Gurken unter Glas. (Virus diseases of tomatoes and cucumbers under glass.) Nachrichtenbl. Deutsch, Zenschutzdienst, 13(2) : 11-13, 1933.

Brief review of the knowledge of the virus diseases of tomatoes and cucumbers occurring in glasshouses.

Ein latentes Kartoffelvirus. (A latent potato virus.) Naturwissensch 21(31) : 578, 1933.

Report of the observations and results attained by the author studying the virus from an apparently health potato transmissible by rubbing with tobaceo, which is termed E 8 .

Untersuchgen über die Viruskrankheiten der Kartoffel. II Studien zur Blattrollkrankheit. (Investigations on the virus diseases of potatoes. II. Studies on leaf roll disease. Phytopath. Zeitschr. 6(4) : 359-369, 1933.

Continuation of previous work on potato leaf-roll disease. Transmission studies by means of the aphid Myzus persicae.

Kohler, E.

Die Viruskrankheiten der Kartoffel. (The virus diseases of the potato.) Biol. Reichsanst. für Land-und Fortwirtsch. Flugbl. 42, 4 p., 1933.

Brief popular account on the occurrence, etiology and control of leaf-roll mosaic, leaf eurl and streak of potatoes in relation to degeneration in Germany.

Untersuchungen über die viruskrankheiten der Kartoffel. III. Weitere versuche mit viren der mosaikgruppe. (Investigations on virus diseases of the potato. III. Further trials with viruses of the mosaic group.) Phytopath. Zeitschr. 7(1):130, 1934 .

Köning, C[ornelia] J[ohan]

Hollandasch Tabak. De Nature 17:368-373, 18:322-339, 357$366,1898$. 
Die Fleckenoder Mosaikkrankheit der Hollandischen Tabaks. (The spot or mosaic disease of Holland tobacco.) Ztschr. Pflanzenkarnk, Bd. 9(2):65-80, 1899.

\section{Koningsberger, V. J.}

Fidji-ziekte op Java. (Fiji disease in Java) Arch. voor de Java Suikerindus 38(25) :581-584, 1930. (Rev. Appl. Mycol. 10 (1) : 58-59, 1931.)

Notes on the observation of the occurrence of "Fiji" disease on canes imported from the Philippines, C. A. 12735 and C. 17. In the Philippines the most susceptible varieties are P.O.J. 288 and DI 52.

\section{Kopp, $\mathbf{A}[$ ndré $]$}

(Peanut rosette.) Rev. Bot. Appl. \& Agric. Colon. 4(30) : 129, 1924.

La mosaïque de la canne de sucre. (The mosaic of the sugar cane disease.) Rev. de Bot. Appl. 5(46) : 411-417, (47) : 519526, 1925. (Rev. Appl. Mycol. 5(1):2, 1926. Sta. Agrom. Guadalupe Tech. Bull. No. 1, 1926. Rev. App!. Ent. ser. A. $13: 530,1926$.

A general discussion of the subject.

La mosaïque de la canne á sucre. (The mosaic of sugar cane.) Rev. Agric. Tle Réunion (10-14):6-8, 1926.

Un cas de longue incubation de la mosaïque de la canne á sucre. (A case of long incubation of sugar cane mosaic.) Rev. Bot. Appl. et d'Agric. Trop. 11(113):37-39, 1931.

The author gives the observations on the slow spread of the disease.

\section{Emmerez de Charmoy, D[onald] d'}

Nouvelles constatations sur la maladies a virus de la canne á sucre et du mais. (New evidence about the virus of sugar cane and corn.) Compt. Rend. Acad. Sci. (Paris) 193:875, 1931.

Observations nouvelles concernant la mosaïque de la canne á sucre et la Streak du mais. (New observations concerning sugar cane mosaic and corn streak.) Sta. Agrom. Ile de la Réunion. Travaux Tech. Bull. 3, 10 p., 1932.

A brief description of the topography of the island. Owing to natural barriers it is impossible for the mosaic to pass from leeward 


\section{THE JOURNAL OF AGRICULTURE OF THE UNIVERSTTY OF P. R.}

to windward part of the island except by the aid of man. The mosaic was introduced 15 or 20 years ago, probably from Java. The disease has spread more abundantly on the leeward. Varieties Luizir and Post Mackay are very susceptible. Best varieties are disappearing because of mosaic and gummosis. Mosaic is carried by cuttings and by Aphis maidis which is abundant. Restricted to a relatively small area on the windward side. Difficult to understand why it is not more general on the windward side. Experimental work at the Station indicates that the disease may be dormant for very long periods of time. Streak is most common in Uba. Also occurs on other canes and corn but is rare on most canes except Uba and R. P. 8. It is transmitted from Coix Lachryma jobi to R. P. 6, by A. maidis. This is contradictory to results of Storey. Uba is more susceptible to virus from Uba than to virus from corn. Virus from Uba and corn does not appear to infect Eleusine indica, but the virus from POJ 213 does infect $E$. indica. The virus is carried by $A$. maidis from corn to corn and from cane to cane. It is also carried from Coix Lachryma jobi to cane. Cane growing near corn which is badly infected with the streak and infected with $A$. maidis did not contract the disease. This was also true of oats. Coix Lachryma jobi and some grasses appear to be reservoirs for the virus.

Situation actuelle de la mosaïque de la canne á la Réunion. (Actual situation of sugar-cane mosaic in Reunion. Travaux Tech. Ile de la Réunion, Bull. 3:11-19, 1932.

A discussion of the distribution and importance of the importation of eanes.

\section{Kornauth, K[arl,] \& Reitmair, O[tto]}

Die Blatrollkrankheit der Kartoffel und ihr Auftreten in Oesterreich. (The leafroll disease of potato and its occurrence in Australia.) Monastshefte fur Landw. Jahrg. 2(3): 79-90, 1909.

Studien uber die Blattrollkranheit der Kartoffel. (Studies on the leafroll disease of the potato.) Mit besonderer Berucksightigung ihres Auftreten und ihrer Vervreitung 1908 in Osterr. Ztschr. Landw. Versu. in Osterr. Jahrg. 3(3) :97-125, 1909.

Kostoff, D.

(Virus diseases causing sterility.) Phytopath. Zeitschr. 5(6): 593-602, 1933.

Report of the author's observations on certain abnormalities of the reproductive organs on some species and hybrids of Nicotiana, induced by virus diseases. He denominates the virus eausing sterility "female sterility virus". 
(A contribution to the sterility and irregularities in the meiotic processes caused by virus diseases.) Genetica 15(1-2) : 103$114,1933$.

Continuation of the previous work of the author at Leningrad on the female sterility virus of tobacco.

\section{Kotila, J[ohn] E[rnest]}

Mosaic and potato yields in Michigan. Michigan. Agric. Exp.

Sta. Quart. Bull. 5(4) : 188-189, 1923.

The author reports a loss of 32 per cent due to mosaic.

\section{\& Coons, G[eorge] H[erbert]}

Trypanosome-like bodies in Solanaceus plants. Phytopathology $13: 324-326,1923$.

This paper gives the results of studies of mosaic and normal plants. The authors found protozoa-like bodies in both but they do not believe them to be protozoa.

Transmission studies of virus diseases of potato in Michigan, 1926-27. Potato Ass'n. Amer. Proc. 14: 95-101, 1927.

A review of contribution to potato pathology which appeared in American publications during year, 1927. Potato Ass'n. Amer. Proc. 14: 226-232. 1927.

Roguing and potato virus disease control. Potato Ass'n. Amer. Ann. Meetg. Proc. 16th. 1929-30:164-168, 1930. (Rev. Appl. Mycol. 9:551, 1930.

This paper gives the results of roguing for the control of these diseases. The percentage of virus disease in the next crop was very high; mosaic and leafroll the highest. The author believes that Solanum dulcamara and Physalis grandiflora were sources of infection.

Experiments with the tuber index method of controlling virus diseases of potato. Michigan Agric. Expt. Sta. Bull. 117, 26 p., 1931.

A description of methods and results of experimental work.

\section{Kottman, G.}

The sereh eane disease. Sugar Cane 23:313-317, 1891.

\section{Kramer, S[imon] P [endleton]}

Experiment with bacterial filters and filterable viruses. Science

$65: 46,1927$

A brief account on the subject in general but not especially on plant viruses. 


\section{Krantz, F[red] A[lbert,] \& Bisby G[uy] $\mathbf{R}$ [ichard]}

Relation of mosaic to running-out of potatoes in Minnesota.

Minnesota Agric. Expt. Sta Bull. 197, 31 p., 1921.

Gives the history, symptoms and methods of transmission of this disease. Also field experiments to determine effect on yields.

\section{Kranzlin, G[ottfried]}

Untersuchungen an Panaschierten Pflanzen. (Investigations on

variegated plants. Zrscht. Pflnazenkrank. 18:193-203, 1908. A record of spectroscopic studies.

\section{Kraybill, Henry R[esist,] \& Eckerson, Sophie, H[ennion]}

Tomato mosaic. Filtration and inoculation experiments. Amer. Journ. Bot. 14(8) : 487-495, 1927.

Used a fritted glass filter and secured (1) a residue which produced mosaic, and (2) a filtrate which produced a fern leaf.

, \&

Separation of fern leaf from mottling in tomato mosaic. Phytopathology $17(1)$ : 57-58, 1927.

\section{Brewer, B[earl] H[arvey], Samson, R[oyburn]}

W[alter,] \& Gardner, Max W[illiam]

The separation from mosaic tomato plants of toxins which prodduce some of the typical symptoms. Phytopathology (Abstract) $19(1): 108,1929$.

A non-infectious leaf-deforming principle from mosaic tomato plants. Phytopathology, 22(7) : 629-636, 1932.

The authors induced a filiform leaf on tomato plants by heavy inoculations with preparations made from tomato plants but which was non-infectious for mosaic. Later growths were normal. The abnormality was not produced with preparations from healthy tomato plants.

Krüger, $\mathbf{K}$.

Beiträge zur Physiologic der Blattrollkrankheit der kartoffel. (Contribution about the physiology of the leafroll disease of potato.) Wiss. Arch. Landow. A. Arch. Pflanzenzan 9(3): 496-524, 1932.

\section{Krüger, W.}

Vorläufige Mitteilungen über die sogenannte "Serehkrankheit" des Zuckerrohres. Ber. Versuchstat. Zuckerrohr. in WestJava, Kagok-Tegal (Java) 1:126-179, 1890.

Weitere Mitteilungen über die Serehkrankheit der Zukerrohres zur Belenchtung des Standes der Serehfrage Ber. Versuchsstat 
Zuckerrohr in West-Java, Kagok-Tegal (Java) 2:122-219, 1896.

Extensive review of literature on sereh disease.

Ueber die Ursache der Serehkrankheit des Zucherrohres. Eine Kritik der Arbeit und Theorie von Wakker. (On the cause of sereh disease of sugar cane. A criticism of the work and theory of Wakker.) Deutsche Zuckerind. 23:225-235, 1898.

\section{Kufferath, H., \& Ghesquiere, J[ean]}

La mosaïque du manioc. (Mosaic of Cassava.) Compt. Rend. Soc. de Biol. 109(12) : 1146-1148, 1932. (Ann. de Gembloux $38(11)$ : 365, 1932.)

The authors report a second mosaic disease of Manihot utilissima, $M$. aipi and M. glaziovii. It is transmitted by an Aleurodidae. The record is from Belgian Congo.

\section{Kulkarni, G[okal] S[ubras]}

Mosaic and other related disease of crops in the Bombay Presidency. Poona Agric. Coll. Mag. 16(1) : 6-12, 1924.

\section{Kunkel, L[ouis] O[tto]}

A possinie causative agent for the mosalc disease of cane. $H$. S. P. A. Expt. Sta. Bot. ser. Bull. 3(1): 44-58, $1921 . \quad$ (Science n.s. $55: 73,1928$. Arch. Java Suikerindus. 1922: 356, 1922.)

Gives symptoms, distribution, varietal resistance and a very thorough discussion of the intracellular bodies which the author believes to be the cause of the disease.

A possible causative agent for the mosaic disease of corn. H.S.P.A. Expt. Sta. Bot. ser. Bull. 3(1) : 1-14, 1921.

Mosaic of sugar cane. Louisiana Planter 69(25):442-443, 1922.

Popular.

Mosaic disease on a new grass host. Hawaii Planters' Rec. $26(3): 163,1922$.

Insect transmission of yellow stripe disease. Hawaii Planters' Rec. 26(2) : 58-64, 1922. (Archiv. Java Suikerind. $30(21)$ : $357-358,1922$.)

Amoeboid bodies associated with Hippeastrum mosaic. Science 55: 73, 1922. 
Studies on the mosaic of sugar cane. H. S. P. A. Bull. Expt. Sta. Bot. ser. 3(2): 115-167, 1924. (Rev. Appl. Mycol. 3: 607-608, 1924.)

Discusses the nature of the disease, method of transmission to other host, effect of sun light and extensive studies on effects on commercial varieties.

Further studies on the intra-cellular bodies associated with certain mosaic diseases. H. S.P.A. Expt. Sta. Bot. ser. Bull. 3(2) : 108-114, 1924. (Rev. Appl. Mycol. 3: 598, 1924.)

Discusses the intra-cellular bodies in several species of plants.

Insect transmission of aster yellows. Phytopathology (Abstract) 14(1): 54, 1924 .

Histological and cytological studies on the Fiji disease of sugar cane. H. S.P. A. Expt. Sta. Bot. ser. Bull. 3(1):99-107, 1924.

Studies on the intra-cellular bodies by Lyon. The evidence is not sufficient to determine their nature.

Insect transmission and host range of aster yellows. Scier:ce n.s. $62(1614)$ : 524, 1926.

Mosaic and related diseases. Amer. Journ. Bot. 12(8):517$521,1925$.

The author discusses question concerning possible causes and methods of transmission and suggests lines of research.

Studies on aster yellows. Amer. Journ. Bot. 13(10) : 646-705. 1926.

Incubation period of aster yellows in its insect host. Phytopathology (Abstract) 16(1):67, 1926.

The author gives a description of the disease and experiments proving that it is earried by Cicadula sexnotata. It is not carried in seeds. It attacks more than 50 species of plants and overwinters in some of them. The same virus caused the Río Grande or white heart of lettuce, bunchy-top of Helichrysum and a disease of buckwheat.

Sterility caused by the aster yellow disease. Amer. Hort. Soc. New York. 3:243-244, 1927. 
"While most mosaic diseases including those that are seed-borne, do not seriously affect seed viability, aster yellows eause sterility in the China aster and in many other species. Diseased plants may pro. duce no flowers, abnormal flowers and no seed, or seeds that do not germinate.',

The corn mosaic of Hawaii distinet from sugar cane mosaic. Phytopathology (Abstract) 17(1)41, 1927. (Rev. Appl. Mycol. 6:438, 1927. Rev. Appl. Ent. ser. A. 15:283, 1927.)

Some characteristic of virus disease of plants. Journ. Bact. 13 (1) : 23-24, 1927.

Virus diseases of plants. In filterable viruses ed. by T. M. Rivers, p., 335-358, 1928.

A very excellent review of our knowledge of the subject to date.

Mayo Foundation Lectures. Lecture on plant pathology in relation to man. p., 17-32, W. B. Saunders Co. Philadelphia, 1928.

Further studies on the host range of aster yellows. Phytopathology (Abstract) 18(1) :156, 1928.

Wire screen fences for the control of aster yellows. Phytopathology (Abstract) 19:100, 1929.

Wilt resistant aster. Phytopathology (Abstract) 19(1):100, 1929.

The aster yellows disease. Proc. Intern. Congr. Plant Sci. Ithaca 2 : 1249-1253, 1929.

Transmission of sida mosaic by grafting. Phytopathology (Abstract 20(1) :128-130, 1931. (Rev. Appl. Mycol. 9:385, 1930.)

Transmission of aster yellows to the tomato. Phytopathology (Abstract) 20(1) : 129, 1930. (Rev. Appl. Mycol. 9: 418, 1930.)

Inoculation period by peach yellows as affected by point inoculation. Science (Abstract) 71(1846):516, 1930. 
Studies on aster yellows in some new hosts plants. Contr. Boyce Thompson Inst. 3(1) : 35-124, 1931.

A record of experimental transmission of this disease to 120 new hosts included in 30 families. The disease had not been transmitted previously to species in 15 of these families.

Local lesions in Aucuba mosaic of tomato. Phytopathology. (Abstract.) 22(1): 16, 1932.

Celery yellows of California not identical with the aster yellows of New York. Boyce Thompson Inst. Contr. 4(3) : 405-414, 1932.

The author describes transmission experiments using Cicadula sexnotata from aster, celery and earrot plants and concluded that the yellows from California differs from the aster yellows of New York in respect to transmission to celery, no other differences having yet been demonstrated.

Insect transmission of peach yellows. Contr. Boyce Thompson Inst. 5(1) : 19-28, 1933.

The author gives the results of experiments with a large number of insects and found that the disease was transmitted by Macropsis trimaculata. About 10 per cent of the trees contracted the disease.

Tobaceo and aucuba-mosaic infections by single units of virus. Phytopathology (Abstract) 24(1):13, 1934.

Studies on acquired immunity with tobaceo and aucuba mosaies. Phytopathology 24(5): 437-466, 1934.

The author deseribes the symptoms by which aucuba and tobacco mosaic may be distinguished on Nicotiana sylvestris. Then gives a thorough and detailed account of his observations.

\section{Kuribayashi, $\mathbf{K}$.}

(On the seed transmission of the bean mosaic.) Journ. Plant. Prot. 13: 199-219, 1926.

(On the relation between the stripe disease of rice plant and Delphacodes steriatellus Fall.) Journ. Plant. Prot. 18:565571, 636-640, 1931.

(Studies on the stripe disease of rice plant.) Nagano Agric. Expt. Sta. Bull. 2: 45-69, 1931. 


\section{Kuster, E[rnst]}

Ueber Mosaikpanaschierung und vergleichbere Erscheiungen.

(On mosaic varietion and comparable phenomena.) Ber. Destsch. Bot. Ges. 36:54-61, 1918.

Not mosaic disease. A discussion on mosaic patterns.

Ueber sektoriable Panaschierung und andare Former der sektorialer. Differenzierung. Monatshefte f. d. Natura. Unters. 12 : 84-87, 1919.

Pathologische Pflanzennatomie. 3 Mufi. 9-39, 1925.

Zur Atiologie des Panaschierungen. (On the etiology of variegation.) Ztschr. f. Planzenkrankkh. 36(5/6): 129-142, 1926.

Beiträge zur Kenntnis der panaschierten Geholze. 14-17 Mitt. Dtsch. Denwl. Ges. Jahrb. p., 258-271, 1926.

Uber Panaschierung. (About variegation.) Proc. Int. Cong. Plant. Sci. (Ithaca, N. Y.) p., 1254, 1929.

Beiträge zur Kenntnis der panaschierten Geholze 31-32. Mitt. Deutsch. Dendrol. Ges. Jahrb. 1931 : 343-348, 1931.

\section{Kuyper, J[an] *}

Overbrenging van Gelestropenziekte door Insecte. (Transmission of yellow stripe disease by insects.) Arch. voor de Java Indus. 30 : 337-358, 1922.

A discussion of a paper by Kunkel.

Het optreden van strepenziekte in den west-moesson van 192324. (The occurrence of stripe disease in the West Monsoon of 1923-1924.) Meded. Proofstat. Java Suiker Indus. 5 :141150, 1924.

Het optreden van sereh in maalriet-en bibituinen in 1925 . Meded. Proefts. Java-Suikerindust. No. 11:275-290, 1925.

Warwaterbehandeling van bibit tegen sereh. (Hot water treatment to "bibit" (seed) against sereh.) Arch. Suikerind. Nederl. Indie 33: 739-743, 1925. 
Bibittuinen, selectic op sereh on strepenzeikte. (Seed beds selection for sereh and stripe disease.) Meded. Proofstat. Java Suiker Indus. 23:949-955, 1926. (Rev. Appl. Mycol. 6: 379, 1927.)

Het verband tusschen slijmziekte en voorfgaande hegroeiing in de proef of Padang Boelen. Deli Proefts. Medan Vlugschr. 41, 5 p., 1927.

\section{Kutín, $\mathbf{A}$ [dolf]}

(Control of potato diseases in the field.) Ochrana Rostlin, Prag. 5:17-19, 1925.

Nomenclature of potato diseases and their causes.) Ochrana Rostlin, Prag. 5:27-28, 1925.

\section{Labergerie}

Action des circuits oscillants sur la dégénérescense des Pommes de terre. Compt. Rend. Acad. Sci. 192(22) : 1408-1410, 1931. Report of experiments with oscillatory circuits on the treatment and Labo, A. prevention of potato degeneracy.

Terapia di montagna in agricoltura. (Mountain therapeutic in agriculture.) Hiorg. Agric. della Domenica Piacenza 38 (39) : 425, 1927.

\section{Lacey, $\mathbf{M}$ [argaret] $\mathbf{S}$ [owerby]}

Protozoa and virus diseases of plants. Nature 112(2808) : 280 281, 1920.

The author reported the finding of protozoa-like bodies in the phloem of mosaic hop plants which resembled those reported by Nelson. She believes them to be degenerate nuclei.

\section{Lackey, C[harles] F[ranklin]}

Further studies of the modification of sugar-beet curly-top virus by its various hosts. Phytopathology (Abstract) 19(12): 1141-1142, 1929. (Rev. Appl. Mycol. 9:256, 1930.)

Attenuation of curly-top virus by resistant sugar-beets which are symptomatic carries. Phytopathology 19(10):975-977, 1929. (Rev. Appl. Mycol. 9: 282, 1930.)

The virus is attenuated by passing through resistant varieties. 
Virulence of attenuated curly-top virus restored by Stellaria media. Phytopathology (Abstract) 21(1) : 123-124, 1931.

Restoration of virulence of attenuated curly-top virus by passage through Stellaria media. Journ. Agric. Rech. 44(10): 755-765, 1932.

Virulent virus of the curly-top of sugar-beet becomes attenuated when passed through Chenopodium murale. This is due to a change in quality, rather than quantity. The attenuated virus from $C$. murale can be restored by passing it through Stellaria media. Virus from the beet is unchanged by its passage through $S$. media.

\section{Lafrenz, E.}

Die Blattrollkrankheit der Kartoffel. (The leafroll disease of potato.) Landw. Wochenbl. Schlesw. Holst. 72: 645, 1922.

\section{Lamkey, E[rnest] IIIichael] $\mathbf{R}$ [udoph]}

A consideration of yellows. Amer. Carnation Ass'n. Proc. 26: 25-35, 1917.

The stomata are closed. There is a reduction in quality or quantity of diastase and an increase in starch and oxidase.

\section{Lang, W[ilhelm]}

On the outbreak of the leafroll disease in Wurttemberg. Wurttemb. Wehnbl. Landw. (23) : 420-422 ; 444-445, 1909.

\section{Laphem, $\mathbf{M}[$ acy] H[arvey], \& Heileman, W[illiam]}

Field operations of the Bureau of soils. U. S. Dept. Agric. Soil

Survey of the Lower Salinas Valley, California, p. 506, 1901.

\section{Larose, E.}

Etat actuel de la culture de la Pomme de terre en Belgique, la possibilité de produire des plantes saines chez nous. (The present situation in potato culture in Belgium, the possibility of producing sound plants by us. Ann. de Gembloux, 32(2) : 265-288, 1926.

\section{Larsen, L. D.}

Diseases of the pineapple. Hawaii Sugar Planters' Ass'n. Path. Phys. Ser. Expt. Sta. Bull. 10, 1910.

The disease at that time was supposed to be due to a Fusarium.

\section{Laske, C[arl]}

Beitrag zur Kenntnis der Viruskrankheiten der Kartoffelpflanze, (Gontribution to the knowledge of virus diseases of the potato plant.) Angewandte Bot. (Abstract) 10(5):478-479, 1928. 


\section{Latham, H. A.}

Spike disease in sandal. Indian For. 44:370-372, 1918.

\section{Laubert, $R$ [ichard]}

Ueber die Bllattrollkrankheit der Syringen und die dabei auftretende abnorme Starkeanhaufung in den Blattern der Kranken Pfanzen. Gartenflora, 63:911, 1914.

\section{Lawrence, W[illiam] H[ereford]}

Insect posts and diseases of bush fruits. Better Fruit Mag. 7 :

18, 1912.

Popular.

\section{Leach, J[ulian] G[ilbert]}

Leafhopper injury to potatoes. Phytopathology (Abstract) 12: (1) : 37, 1922 .

\section{\& Stakman, E[lvin] C[harles]}

Garden truck diseases. Minnesota Agric. Expt. Sta. Rpt. 1922 : 99-100, 1922.

Cucumber mosaic. Minn. Hort. 54: 177-179, 1925.

Leak, G. D.

The breaking of tulips. Flor. Exch. 67:128-129, 1928.

Lebard, $\mathrm{P}$ [aul]

Relations entre l'altitude, l'humité et les substitutions de dégénérescence de la Pomme de terre. (Relations between altitude, humidity, and the forms of degeneration of the potato.) Compt. Rend. Acad. d'Agric. de France 16(30):999-1004, 1930.

A discussion on the subject based on observations made by the author in the French Alps.

Ledeboer, F.

Gelestrepenziekte. (Yellow stripe disease.) Arch. Suikerindus, Nederland. Indië. Jarg. 29: 1000-1001, 1921. (Deutschs Sinkerindus. $46: 501,1921$.)

Gelestrepenziekte. (Yellow stripe disease.) Arch. voor de Java Suiker Indus. 30 (21) : 359-362, 1922. (Facts About Sugar 22 : $557-577,583-588,769,839,24: 154.224,418,1923$. Int. Sugar Journ. 26:18-21, 1924. Rev. of Appl. Mycol. 2:233, 1923.)

The writer discusses a paper by van Harreveld and gives the results of his own studies with insects. 
Ziekten en Plagen. (Diseases and pests.) Verslag Ondera Cheribon, Proefts. Java Suikerindust, p. 12-16, 1922.

\section{Ledingham, J. C. G.}

The differentiation of plant virus. Rpt. Proc. 5th. Int. Congr. Bot. Cambridge. p. 374-379, 1930.

Lee, H[enry] Atherton \& Medalla, $\mathbf{M}$ [ariano] G.

Yellow stripe disease of cane in the Philippines. Sugar Cent. and Planters' News. 1(13):36; (14):12-17, 1920. (Sugar 23 : 53-54, 1921.)

\& Welles, C[olin,] G[ilchrist] \& IMedalla, IM[ariano] G.

Fiji disease of sugar cane in the Philippines. Philippine Agric. Rev. 14: 413-417, 1921. (Sugar 24:676-677, 1922.)

Cane disease in Negroes. Sugar Cent. and Planters' News: $2(21)$ : 568-569, 1921.

\section{\& Kopke, E[rnest] W.}

Mosaic disease of sugar cane in the Philippines. Philippine Agric. Rev. 14(4) : 418-421, 1921. (Sugar Cent. and Planters' News. 4(9) : 442-448. Rev. Appl. Mycol. 2:141. Rev. Appl. Ent. Ser. A. 11:348, 1921.)

A history and deseription of the disease.

, \& Medalla, $\mathbf{M}[$ ariano] $\mathbf{G}$.

The seasons' experiments on Fiji disease, mosaic disease and smut of sugar cane. Philipp. Agric. Rev. 14(4) : 402-412, 1922. (Rev. Appl. Mycol. 2:88, 89, 1923. Rev. Appl. Ent. ser. A. $11: 348,1923$.

This paper gives the results of field studies with these diseases.

\section{\& Locsin, Carlos, IVIontilla, Emilio, \& Ocampo, Ricardo}

Report of the Committee on cane disease. Philippine sugar Ass'n. Sugar Cent. and Planters' News 4(10) : 505-520, 1923. (Hawaii Planters' Rec. 30(1) : 38-48, 1926.)

A thorough report of sugar-eane diseases, especially Fiji, and mosaic.

Sereh disease of sugar cane in Singapore. (Phytopathology 13 (3) : 145, 1923.

A record of this disease on canes that had been introduced from Java. 
Present needs in cane disease control. Int. Sugar. Journ. 26 (310) : 543-545, 1921. (Trop. Agric. 64:35-37, 1925. Sugar 26:433-434. Id. Abst. (Spanish) 26:525, 1925.)

Sugar cane disease. (Digest of the proceedings of the first conference of the International Society of Sugar Cane Technologists, Honolulu, Hawaii 1924:9-12, 1925. (The Plant \& Sugar Mfg. 74(11):210-212, 1925.)

The common grasses in Hawaii in relation to mosaic or yellow stripe disease. Hawaii Planters' Rec. 30(2):270-278, 1926. A list of susceptible grasses.

Estimated damage by mosaic. Ann. Rpt. 7th Conv. Philipp. Sugar Ass'n 1929. (Facts About Sugar (Abstract) 25(13): 312-313, 1930.)

\section{\& Medalla M[ariano] G.}

P. O.J. 2878 is susceptible to cane smut. Sugar News. 12(4): 220-221, 1931.

Tabulation is given of three major cane diseases, in Luzón, Philippines. Smut, mosaic and Fiji. Percentage of susceptibility is given on each variety observed.

\section{Leefmans, $\mathbf{S}$ [alomon]}

Ziekten en plagen der cultuurgewassen in Nederlandsch-Indie in 1928. (Diseases and pests of economic crops in the Dutch East Indies in 1928.) Meded. Inst. voor Plantenziekten, 75: 96, 1929. (Rev. Appl. Mycol. 9(3): 160, 1930.)

Ziekten en plagen der eultuurgewassen in Nederlandsch Oest Indie in 1929. (Diseases and pests of cultivated crops in Dutch East Indies in 1929.) Meded. Inst. voor Plantenziezten 79. 100 p., 1930.

Leafroll and mosaic on potatoes was prevalent on the east coast of Sumatra.

\section{Lees, $\mathbf{A}[$ lan] $\mathbf{H}[$ enry]}

"Reversion" of black currants. Journ. Bath. West Countries Soc. 5 : 135-138, 1918.

Gives an explanation of the probable causes, which he believes to be due to a checking of the terminal growth. 
Reversion and resistance to big bud in black eurrants. Ann. Rpt. Agric. and Hort. Res. Sta. Long Asliton. Bristol. 5: 1127, 1918.

A method of identifying reversion of black currants. Univ. Bristol Ann. Rpt. Agric. and Hort. Res. Sta. p., 66-70, 1920.

The association of black currant mite, (Eriophyes ribis) with reversion disease. Ann. Rpt. Agric. and Hort. Res. Sta. Long Asliton, Bristol, 1921.

Reversion of black currants: A method of identification. Journ. Ministry Agric. (Great Britain) 27:1122-1127, 1921.

A description of the disease.

The association of black currant mite. (E. ribis) with reversion disease. Journ. Bath. West and South Co. 5(16) : 237241, 1922.

Statistical studies on the propagation of big bud and reversion disease of black currants. Ann. Rpt. Agric. and Hort. Res. Sta. Long Asliton, Bristol, 1922.

The percentage of diseased plants in a season ranged from nothing to 20 per eent.

Leaf character in reverted black currant. Ann. Appl. Biol. 9(1) : 49-68, 1922.

A discussion of symptoms and of agencies that are suspected as being causes of the disease.

Reversion in black eurrant. Gard. Chorn. III, 72 : 65, 1922.

The influence of reversion (Nettle Leaf) on successful black currant growing. Journ. Bath. West and South Co. 5(16): 180-182, 1922.

Ann. Rept. Agric. and Hort. Res. Sta. Long Asliton, Bristol, 1923 : 69-72, 1923.

Reversion disease of black currants; means of infection. Ann. Appl. Biol. 12(2):199-210, 1925. (Ann. Rpt. Agric. and Hort. Sta. Univ. Bristol 1925 : 66-76, 1925.) 


\section{Lehman, S[amuel] G[eorge]}

Tobacco Plant Pathology at the North Carolina Sta. North

Carolina Agric. Expt. Sta. Ann. Rept. p. 97-100, 1930.

Work in progress on tobaceo mosaic.

\section{Le Pelley, Richard, H[enry]}

Introductory note on virus diseases of plants in Kenya. Journ. Hist. Soc. 37 : 198-200, 1931.

A popular discussion.

\section{Leroux, L[ucien]}

La chloroses des plantes. (Chlorosis of Plants.) Rev. Gen. Sici. Pur. et Appl. 36:418-420, 1925.

\section{Lesley, J[ames] W[yvill,] \& Lesley, MIargaret] [Campbell] M[ann]}

The wiry tomato. A recessive mutant form resembling a plant affected with mosaic disease. Journ. Heredity, 19(8) : 337344, 1928.

The resistance of varieties and new dwarf races of tomato to curly-top (Western yellow blight or yellows.) Hilgardia 6 (2) : 27-44, 1931.

The resistance appears to be due to a tendency to eseape infection rather than a tolerance to the virus.

\section{Levshin, A. IM.}

(Occurrence of elytrosomes in the leaves of mosaic diseased sugar beet.) In V. P. Muraviov, Mozaichnye Bolezni Sakharnoi Svekly (Mosaic diseases of sugar beet.) Kiev. S.S.U. Souizsakhara p. 177-178, 1930. (English Abstract p. 178.)

The author's observations and studies confirm those by Schaffnit and Wever in regard to the occurrence of small bodies in mosaic-diseased sugar beets. $\mathrm{He}$ describes those bodies.

Lewin, C. J.

On the incidence of leaf curl of cotton in South Nigeria. Ni. geria Dept. Agric. Ann. Bull. 6: 70-77, 1927.

A history of the disease up to this time and the results of experimental work.

Lewton, Brain L.

Disease resisting varieties of plants. West Indian Bull. 4(1): 48-57, 1903. 
Likhité, V. N.

(The nature and relations of the intracellular inclusions present in the mosaic of tobacco.) Medeel. Landbouwhoogesch. Wageningen 33(1) : 3-25, 1929.

Cytological aspects of the virus diseases in plants. Mededieel Landbouwhoogesch. Wageningen 33(2): 1-12, 1929.

\section{Lind, J[ens]}

Stuchen uber die segennante Panashure und uber einge begleitende Erscheinungen. Landw. Jahrb. 36:807-862, 1907.

Runkelroerness mosaiksyge. (Mosaic disease in beets.) Tidsskrift for Planteave 22 : 444-457, 1915. (Int. Rev. of Sci. and Pract. of Agric. 7(5):747, 1916.)

\section{\& Rostrup, Sofie}

Maanedlige oversigter over sygdomme has Landbrugets. Kulturplanter fra staten plantepatologistke. Forsog, 1916.

\section{Lindemuth, H[ugo]}

Versammlung des Vereines zur Beforderung des Gatenbance am 1897. Gartenflora 46:537, 598, 1897.

Ueber verschiedene Arten den Panaschure, deren Uebertragbarkeit durch Transplantation und. Samenbestandigkeit. Gartenflora 54:125-128, 1905.

Studies uber die sogenannte Panaschure und uber einige begleitende Erschenungen. Landw. Jahrb. 36:807-862, 1907.

\section{Linford, IVIaurice] $\mathrm{B}$ [lood]}

Pineapple yellow spot transmissible by thrips. Pineapple News $4: 43-51,1930$.

Evidence showing that the disease is transmitted by thrips.

Yellow-spot disease of pineapple transmitted by Thrips tabaci Lind. Science n.s. 73(1888): 263, 1931. (Hawaii Pineapple Canners' Stat. 1:53-61, 1931.)

Thrips tabaci has been found responsible for the transmission of yellow spot disease of pineapple in Hawaii.

Further studies of transmission of the pineapple yellow-spot virus by Thrips tabaci. Phytopathology (Abstract) 21(10):999, 1931. 
The transmission of yellow-spot by Thrips tabaci. Pineapple Quart. 1(2) : 53-62, 1931.

A record of the experimental work. The disease occurred also on Emilia saggittata.

Streak a virus disease of peas transmitted by Thrips tabaci. Phytopathology (Abstract) 21(10): 999, 1931.

A streak disease of common peas (Pisum sativum) observed in 1928. Thrips tabaci transferred to peas from Emilia sagittata (E. flammea) developed the streak. T. tabaci transferred from peas to peas and to pineapple caused streak and yellow-spot. Streak of peas appears to be the same as yellow-spot of pineapple.

Transmission of pineapple yellow-spot virus by Thrips tabaci. Phytopathology 22(4) : 301-324, 1932.

Detailed report of the writer's observations on the transmission of the pineapple yellow-spot virus by Thrips tabaci. The author also considers the relation of the insect vectors with other plant hosts, e. g. Senecio hieracifolia, Bidens pilosa and Sonchus oleraceus.

\section{Linhart, G[yorgy] \& INezey, G[yuls]}

A Dohany Mozaikfetegsege. Kulonleny omat á Mezögardesagi szemle. Bol. 1890:1-10, 1890.

Die Californisch rübenkrankheit. (The Californian sugar beet disease.) Oesterr. Ungar. Ztschr. Zuickerindus. u. Landw. $30: 26-42,1901$.

\section{Link, Adeline IVae De Sale}

Mosaic and leafroll of the potato in the northwest. Phytopathology (Abstract) 13(1): 39, 1923.

Link, G[eorge] K[onrad] K[arl,] Jones, Philip IM. \& Taliaferro, W[illiam] $\mathrm{H}$ [ay]

Possible etiological role of Plasmodiophora tabaci in tabacco mosaic. Bot. Gaz. 82(4) : 403-414, 1926.

The results of experiments with this organism indicate that it is more abundant in diseased than in healthy plants.

\section{Lipschutz, B [enjamin]}

Ueber Mikroskopisch sichtbare, filtrierbare Virusarten. Ueber Strongyloplasmen. Centbl. Bakt. Abt. 1, Orig. 48:77-90, 1908. 
Die mikroskopich Darstellung des filtriebaren Virus (Chlamy* dozoa-Strongyloplasmen.) Kraus, R. und Uhlenhuth, P., Handbuch der mikrobiologischen Technik, 1:381-412, 1923.

\section{Liro, J. I[var]}

Ueber die mosaikkrankheit der Prunella vulgaris L. Ann. Soc. Zool-Bot. Fennicae Vanamo, 11:143-149, 1930.

Ledewijks, J[ohan] A[nthon] Jr.

Zur Mosaikkrankheit des Tabaks. (Mosaic disease of tobacco.) Trav. Bot. Neerlandais 7:107-129, 1910. (Bot. Centralbl. (Abstract) 114: 518, 1911. Centralbl. f. Bakt. $31: 324,1910$. )

\section{Loew, [Carl Benedict] Oscar}

Phytological studies of Connecticut leaf tobaceo. U.S.D.A.

Division of Veg. Phys. and Pathology. Rpt. 65:24-27, 1900.

Describes tobaceo mosaic and gives results of enzyme studies. Also results of experiments with fertilizer and seed bed treatments.

\section{Lojkin, IMary \& Vinson, Carl G[eorge]}

Effects of enzymes upon the infectivity of the virus of tobacco mosaic. Boyce Thompson Inst. Contr. 3(2) : 147-162, 1931.

The effects of pepsin, yeast extract, trypsin, papain and erepsin under experimental conditions is given. Boiling destroyed the capacity of the enzyme solution to reduce infectivity of the virus preparations.

Catalase-A new enzyme of general occurrence. U. S. D. A. Div. of Veg. Phys. and Pathology Rpt. 68:1-47, 1901.

\section{López Domínguez, F[rancisco] A[ntonio]}

Has yellow stripe or mottling disease any effect on the sugar content of cane juice? Journ. Dept. Agric. Porto Rico 3(4): 47-64, 1919.

Analitical studies which indicate that the disease does not affect materially the sugar content of the juices unless the stalk is drying.

Chemical variations in yellow striped cane. Insular Expt. Sta. Porto Rico. Ann. Rpt. 1920: 77-78, 1920.

La caña Uba y su rendimiento de azúcar en Puerto Rico. (Yield of the Uba cane in Porto Rico.) Ins. Exp. Sta. Porto Rico. Bull. 28, 1923. English \& Spanish Eds.

The author points out the importance of this variety to save the sugar-cane industry from the mosaic epidemic. 
El matizado o mosaico de la Caña: Sus síntomas sobresalientes. (Sugar Cane mosaic: Outstanding symptoms.) La Vida Agrícola, Lima, Perú. 4(46) : 803-806, 1927.

Mosaico de la caña de azúcar. Inform. \& Mem. Soc. Ingen. Perú 10(30): 445-455, 11:466-478, 1928.

Popular.

El matizado de la caña. Método para su represión. (Sugar cane mosaic, methods for its control.) La Vida Agrícola, Lima, Perú, 5(50) : 89-98, 1928.

El mosaico de la caña de azúcar. (Sugar cane mosaic.) Est. Expt. Agric. de la Soc. Nac. Agraria de Perú, Circ. No. 10, 23 p., 1928.

Conference before the Engineers' Society of Perú. The author deseribes the disease and reviews the wcrk done to eradicate it. He advises the planting of immune or resistant varieties.

\section{Loree, $\mathbf{R}$ [obert] $\mathbf{F}$ [arls,] \& Bennett, C[arlyle] W[ilson]}

The raspberry situation in Michigan. Michigan Agric. Expt.

Sta. Quart. Bull. 5(1) : 31-33, 1922.

Brief popular account of the situation, among other considerations gives roguing as a measure to control mosaic and other diseases.

\section{Loughnane, James B.}

Insect transmission of virus A. of potatoes. Nature 131(3319): 838-839, 1933.

Study of transmission of potato virus A at the Alberta Agricultural College, Dublin. The author concludes that Myzus persicae is an efficient vector of virus A from potato to potato and tobacco. Virus A may also be transmissible by $M$. circumflexus, but attempts to cause infection by means of M. solani, Lygus pabulinus, and Calocoris bipunctatus gave negative results.

\section{Ludewig, $\mathbf{K}[\mathrm{arl}]$}

Beitrage zum Studium der Blattrollkrankheit der Kartoffel. (Contribution to the study of leafroll of potatoes.) Landw. Jahrb. 63(2): 277-303, 1926.

Results of experiments on starch transfer as in Hiltner's experiments gave negative results.

\section{Ludtke, M.}

Utersuchungen uber Viruskrankheiten. Beitrage zur kenntnuis des Stoffwechsees mosaikkranker und gesunder Tabakpflan- 
zen. (Investigations about mosaic disease. Contribution on the study of assimilation in mosaic diseased and sound tobacco plant. Phytopath. Ztschr. 2(4) : 341-359, 1930.

The increase of starch in the mosaic plants does not depend on the decreased efficiency of diastase.

\section{Lushington, P. IM.}

Spike disease in sandal. An interesting isolated area and its treatment. Indian Forester 44:114-117, 1918.

Brief report of the procedures.

Progress of spike investigation in the southern circle, Madras Presidency, during 1917-18. Indian forester 44:439-460, 1918.

The author summarized his previous work (Indian Forester 44: 114) and Venkatarama Ayyar (Indian Forester 44:316) stating additions.

Lyman, G[eorge] $\mathbf{R}$ [ichard] et al

Report of the conference on diseases of potatoes and seed certification. Washington: War Emergency Bd. Amer. Plant. Path. 1918: 1-20, 1918.

\section{Lyon, H[arold] L[oyd]}

A new cane disease now epidemic in Fiji. Hawaii Planters' Rec. 3(4) : 200-205, 1910.

Losses due to yellow stripe disease. Hawaiian Planters' Rec. 6(5) : 258-263, 1912.

Lahaina cane injured by yellow striping. Hawaii Planters' Rec. $10(5): 320-321,1914$.

Fiji disease in New Guinea. Hawaiian Planters' Rec. 12: 200, 1915.

Three major diseases, mosaic, Sereh and Fiji disease. Hawaiian S. P. A. Expt. Sta. Bot. ser. Bull. 3(1) : 1-43, 1921. (Agric. News. 21(517) : 62; 78-79, 1922. Rev. Appl. Mycol. 1:184186, 1922.)

A very thorough study of the symptoms and methods of control. Also a study of the causal agent of Fiji.

Cane Pathology. Hawaii S. P. A. Expt. Sta. Rpt. Comm. in charge 1923:18-22, 1923. (Rev. Appl. Mycol. 3:482, 483, 1924.) 


\section{Mac Callum W[illiam] G[eorge]}

Present knowledge of filterable viruses. Medicine 5:59-78, 1926.

\section{Mac Clement, D., \& Smith, J[ohn] Henderson}

Filtration of plant viruses. Nature $130(3273): 129-130,1932$.

Used collodion membranes but found it desirable to standardize every membrane individually. The membranes become clogged with plant materials. However, the authors were able to come to some conclusions concerning the sizes of the particles in several viruses.

Mackenzie, D[onald]; Salmon, E[rnest] S[tanley]; Ware, William M[elvill]e, \& Williams, R. D.

The mosaic disease of the hop; grafting experiments, II. Ann. Appl. Biol. 16(3) : 359-381, 1929. (Rev. Appl. Mycol. 9(2) : 131, 1930.)

This paper is a record of grafting with a number of varieties.

\section{Mackie, W[illiam] W[ylie], \& Esau, Katherine}

A preliminary report on resistance to curly top of sugar beets in bean hybrids and varieties. Phytopathology (Abstract) $21(10)$ : 997, 1931.

A preliminary report on resistance to curly top of sugar beet in bean. Phytopathology 22(3) : 207-216, 1932.

A more detailed, expanded and fully tabulated account of the writer's previous work in California on varietal resistance to curly-top of sugar beet among beans (Phaseolus vulgaris).

Mac Lennan, A[rchibald[ H[enderson,] \& Presant, F[rederick] W. Tomato mosaic. Ontario Dept. Agric. Bull. 308: 25-26, 1924. Popular notes very brief.

IMac Leod, D. J.

Control of mosaic, leafroll and spindle tuber diseases of the potato. Dominion Expt. Farms. Seasonal Hints, East \& B. C. Ed. No. 41, 1928.

Effect of size of seed used in commercial planting on the occurrence of virus diseases in potatoes. Dominion Expt. Farms Seasons Hints, 51: 9-10, 1931.

A brief paper giving results.

Aster wilt and aster yellows investigations in disease resistance. Canada Dept. Agric. Div. Bot. Rpt. Dom. Botanist, 1930: 22-23, 1931. 


\section{MacIillan, H[oward] G[ove]}

Potato mosaic masking at high altitudes. Phytopathology (Abstract) 13(1):39, 1923.

\section{IMacoun, W[illiam] T[yrrell]}

The potato in Canada. Canada Dept. Agric. Bull. 90, 100 p.. 1918.

\section{Magee, C[harles] J. P[atrick]}

Investigations on the bunchy top disease of banana. Australian

Council Sci. \& Indus. Res. Bull. 30(1) : 7-64, 1927.

A history of the disease in Australia, its geographical distribution and a description of the symptoms.

Virus or degeneration diseases of potatoes. Agric. Gaz. New South Wales. 41(6): 405-412, 1930.

These diseases are prevalent and the infection with leafroll is somotimes as high as 75 to 85 per cent. The author gives suggestions for roguing and seed improvement.

A new virus disease of banana. Agric. Gaz. New South Wales 41(12) : 929, 1930.

In May 1929 there was observed a new disease on banana with all the appearance of a virus disease. Preliminary experiments showed that it may be transmitted by the banana aphid Pentalonia nigronervosa.

Virus diseases of potato. Control methods for tableland grow-

ers. Agric. Gaz. New South Wales. 42(11) : 839-841, 1931.

A brief discussion of control.

\section{Magrou, J[oseph]}

Virus filtrants et chamydozoaires. (Filterable viruses and Chlamydozoa.) Rév. Path. Vég. et Entomol. Agric. 10:4143, 1923.

The author compares the bodies found by Kunkel in corn and Hippeastrum, with bodies by Negri in rabies, by Palm in tobacco and by Guarnieri in small pox. Most authors consider these bodies as desintegration products of the cell.

\section{Maige, L[ouis] A[lbert]}

A new disease of beans. Bull. Agric. Algérie et Tunisie 9(14): 334, 1903.

Malhotra, R. C.

Biochemical investigation of mosaic in Solanum tuberosum. Journ. of Biochem. 13(3):473-487, 1931. 
A brief review of the literature followed by the results of chemical studies.

\section{Malpeaux.}

Pour éviter la dégénérescense des Pomme de terre; choix preparation et conservation des tubéreules de semence. (To avoid the degeneration of potato; selection, preparation and conservation of the seed tubers. La vie Agric. et Ruralle. Déc., 1918.

Mandelson, L. F.

Citrus psorosis control. Queensland Agric. Journ. 40(6) : 504 507, 1933.

Brief popular account of the disease and report of its occurrence in Queensland since 1927. The author describes the Californian method of controlling it. (This is not a paper on virus diseases strictly, but as this disease has been recently considered as caused by a virus, it is of interest to students on virus diseases.)

Mandenburg, E[dmund] C[arl]

Compulsory eradication of little peach and peach yellows. Michigan State Hort. Soc. Ann. Rpt. 57: 66-70, 1927.

Manns, T[homas] F[ranklin], \& Adams, J[ames] F[owler]

Report of the Department of Plant Pathology and Soil Bacteriology. Delaware Agrie. Expt. Sta. Bull. 129:18-28, 1921.

Report of the Department of Plant Pathology. Delaware Agrie. Expt. Sta. Bull. $138: 26-33,1922$.

., \&

Department of Plant Pathology and Soil Bacteriology. Delaware Agric. Expt. Sta. Bull. 135: 25-46, 1924.

\section{IMarchal, Emile [Jules Joseph]}

La mosaïque du tobac. (Tobacco mosaic.) Revue Mycologique $19: 13-14,1897$.

Rapport sur les travaux de la Station de Pathologie végétale de Paris in 1922. (Report of the work done by the Plant Pathology Station, in Paris in 1922.) Ann. des Epiphyties 9(1) : 70-72, 1923.

Report on potato mosaic.

Les maladies a virus filtrants en pathologie végétale. (The filterable viruses diseases in vegetable pathology.) Ann. de Gambloux 36(6) : 177-195, 1930. 
Report of virus diseases on Fuchsia, Antirrhinum, rose and $\boldsymbol{H}$ drastis canadensis.

Belgium: short account of crop disease conditions in 1930. Internat. Bull. of Plant Protect. 5(3):37-38, 1931.

Brief notes on diseases are given among which is mosaic disease of of chicory (Cichorium intybus).

\section{Márquez, Severo L.}

Fiji disease of sugar cane. Bureau of Agric. Philippine Islands

Circ. 174. (Philippine Agric. Rev. 18(4) :573-574, 1925.

A brief popular discussion of the disease.

\section{IMarre, Eugene.}

La dégénérescence de la pomme de terre. Mission d'études en Hollande. (Degeneration of the potato. Commission of studies in Holland.) 52 p. Imprimerie Carrére Rodez, 1921. An account of a French mission to Holland for information on the subject. Recommendations for the control of these diseases.

\section{Marshall, William}

The Rural Economy of Yorkshire 2:51-67, 1888. (London. T. Calell.)

\section{Martin, C.}

Discussion on ultramicroscopic viruses infesting animals and plants. Proc. Roy. Soc. B104: 537-560, 1929.

\section{Martin Jr., G[eorge] Hamilton}

Mosaic of Dahlias. Diseases of forest and shade trees, ornamental and miscellaneous plants in the United States in 1922. Plant Disease Bull. Suppl. 29:393-461, 1923. (Mimeographed on page 435.)

Report of virus diseases on Fuchsia, Antirrhinum, rose and Hydrastis canadensis.

Disease of forest and shade trees, ornamental and miscellaneous plants in the United States in 1925. U.S.D.A. Plant Disease Report. Suppl. $50: 413-478,1926$.

Report of virus on Bougainvilea spectabilis, Pelargonium, Hibiscus rosa-sinensis, Delphinium, Viola tricolor, Primula, Ambrosia trifida, and Asclepias spp.

Diseases of forest and shade trees, ornamental and miscellaneous plants in the United States in 1926. U.S.D.A. Plant Disease Reporter, Suppl. 55:334-393, 1927.

A record of cur?y-top virus infecting China aster (Callistephus Chinensis. 
Diseases of forest and shade trees, ornamental and miscellaneous plants in the United States in 1928. Plant Disease Reporter, Suppl. 73:366-396. (Mimeographed.) 1929.

Report on Gladiolus 385 and Iris 387 mosaic.

\section{Martins, J[oseph] P[olkinghorne]}

The germination of healthy and mosaic-affected cuttings selected from the same stool. Hawaii Planters' Rec. 33:143-144, 1929 .

Chlorotic streak disease of sugar cane. Hawaii Planters' Rec. $34: 375-378,1930$.

This paper gives the results of studies demonstrating a new virus disease.

Field control mosaic disease in Hawaii. Proc. 4th congress Internat. Soc. Sugar Cane Tech. Facts About Sugar (Abstract) $27(8): 365,1932$.

The disease is much less serious than in the past, owing to rigid field selection and the use of resistant varieties.

Pathology H.S.P.A. Proc. Fifth-second Ann. Meeting 1932: 23-42, 1933.

Account of sugar-cane mosaic and chlorotic streak of Coix Lachrymajobi.

\section{Martin, William H[ope]}

"Spindle-tuber", a new potato trouble. Hints to Potato Growers. New Jersey State Potato Assoc. 3(8); 1922.

Spindle tuber. A disease of potatoes. New Jersey Agric. Expt. Sta. Ann. Rpt. 44:345-347, 1923.

Marins Ramos, C. S.

O combate do mosaico (The fight against mosaic.) Bol. Agric. Bahia (Brazil) 15:29-33, 63-65, 1926.

Novo methodo para cambatir apropagacao de "mosaico na canna de assucar". (New method of fighting the propagation of "mosaic of sugar eane".) Bol. Min. Agric. Ind. e Comm. Brazil 15:793-795. (Correio Agric. Soc. Bahiana Agric. 4: 199-201, 1926.

This paper is based on Alfaro's studies on the migration of the Aphid maidis and recommends planting so that the cane can make a maximum growth before the period of migration. 


\section{Martyn, E[ldred] B[ridgeman]}

Mosaic disease of cane. Agric. Journ. of British Guiana 3: 112-113, 1929.

Botanical and Mycological Division Annual Report 1929. Agric. Journ. British Guiana 3(4): 226-233, 1930.

Sugar-cane mosaic has been reported from British Guiana before. In 1929 was found in several fields mostly in the variety D-625. Attempts have been made to control it but 100 per cent infections was present on the third and fourth ratoons.

\section{IMarudarajan, D.}

Mosaic disease of sugar cane. Journ. Madras Agric. Stud. Union 15: 49-56, 1927.

\section{Marx, T., \& Ierkenchlager, F[riedrich]}

Zur biologie der kartoffel. 12. Mitteiking. Beobachtungen und untersuchungen über den verlanf des kartoffelabbaues. (On the biology of the potato. Note 12. Observations and Investigation on the course of potato degeneration. Arb. Biol. Reichsanst, fur Land-und Forswirtsch, 19(5) : 413-492, 1932.

The author discuss symptoms and characters not usually mentioned and the results of some chemical studies.

Massee, A. IM. et al.

Experiments in the transmission of reversion in black eurrants.

East Malling Res. Stat. Ann. Rpt. II. Suppl. p. 126-150, 1927.

Further observations on the strawberry Tarsonemid mite (Tarsonemus fragariae Zimm.) East Malling Res. Sta. Ann. Rpt. 1932 : 117-131, 1933.

Account of the possibility that the mite Tarsonemus fragariae Zimm. is a vector of the virus disease "Yellow edge" on strawberries.

Massée, G.

Perpetuation of potato disease and potato leaf curl by means of hibernating mycelium, Kew Bull. 1906, p. 242-245, 1906.

IMassey, R. E., \& Andrews, F. W.

The leaf-curl disease of cotton in the Sudan. Empire Cotton Growing Rev. 9(1) : 32-45, 1932.

A preliminary paper giving the history, symptoms, transmission and other data concerning this disease. 


\section{Mathur, R. N.}

Leaf curl of cotton in garden Zinnias in North India. Nature $129(3265): 797,1932$.

Brief account of a virus disease in garden zinnias identical with leaf curl and transmitted by the same vector (Bemisia gossypiperda.)

Leaf-curl in Zinnia elegans at Dehra Dun. Indian Journ. Agric. Science 3(1) : 89-96, 1933.

Description, symptoms and nature of a disease occurring at Dehra Dun, India. The disease is transmitted by Bemisia gossypiperda. This disease is very similar to a cotton disease in Sudan and transmitted by the same vector. Report of results of transmission experiments, fully detailed and tabulated.

\section{Matsumoto, Takashi}

Further studies on the legume mosaic. Journ. Plant. Protect.

9: 517-520, 1922.

Some experiments with azuki bean mosaic. Phytopathology $12(6)$ : 295-297, 1922.

The author gives a description of the symptoms and the histology of the diseased plants.

(Azuki bean mosaic). Japanese Journal Plant Protect. 9(1): 13-17, 1922.

This paper gives a description of the disease and the results of histological studies.

Antigenic properties to tobacco mosaic juice. Journ. Soc. of Trop. Agric. 1(3) : 291-300, 1930.

The author gives the results of experiments which will be summarized as follows: "As stated in the foregoing tables the tobacco mosaic juice was capable of stimulating the production of specific precipitating antibodies when the former was injected into a rabbit. This antiserum was also able to inhibit the infective action of the virus under the circumstances as mentioned above. The infective principle of the virus was precipitated by an specific action of the antiserum, consequentiy the supernatant liquids were left sterile, but in the normal serum-virus mixture the infective principle was not appreciably affected nor separated by the serum. It is by no means clear, however, whether this precipitating reaction is due to the specific action of the infective principle of the virus or rather may be referable to an interaction of some concomitant antigens which are associated with the infected principle of the tobaceo mosaic virus and inseparable from the infective principle by means of ultrafiltration or treatment with alcohol.", 


\section{Somazawa, Koetsu.}

Immunological studies of mosaic disease and heat in activation on the antigenic properties of tobacco mosaic juice. Part I., \& Part II. Journ. Soc. of Trop. Agric. 2(3) : 223-234, 3(1) : 24-33, 1930.

The authors continue their studies on the antigenic properties of tobaceo mosaic juice.

\&

Immunological studies of mosaic disease. II. Distribution of antigenic substances of tobacco mosaic in different parts of host plants. The Phytopathological Lab., Taihoku Imp. Univ. Formosa, Japan. Contr. 4(2): 161-168, 1932.

It has been demonstrated that when leaf extracts of mosaic tobacco are injected into rabbit, it is capable of causing a specific precipitate of antibodies. The author gives the inference that the antigenic reaction is actually due to the infective agent.

\&

Immunological studies of mosaic diseases. III. Further studies: on the distribution of antigenic substances of tobacco mosaic: in different parts of host plants. Journ. Soc. Trop. Agric 5(1) : 37-43, 1933.

The authors state that "the presence of the antigenic substance, probably an infective principle itself, is definitely demonstrated in the xylem portion of any infected tobaceo plants. It was also confirmed: that the virus principle was capable of entering the xylem portion even: through an unbroken wall, probably through pits in the walls. With regard to the pathway normally taken by the virus in the living plants however, no definite conclusion can be given at present."

\section{Mattei, G[iovanni] $\mathbf{E}$ [ttore]}

La variegatura della foglie é douta a batterii? (Is variegation of the leaves due to bacteria? Riv. Biologica 8:41-61, 1926.

A summary of work showing that mosaic of plants is eaused by bacteria.

Matthews, W. H.

The agricultural progress of the Pomoroon between the years:

1905-1917. British Guiana Journ. Agric. 12(1) : 6-10, 1919.

A brief report.

\section{IIatz, Julius}

Infection and nature of the yellow stripe diseases of cane.

Journ. Dept. Agric. Porto Rico. 3(4) : 65-82, 1919.

Results of experiments and histological studies. The author describes a granular plasma in some of the cells which he believes may be a cause of the disease. 
Ultimos desarrollos en la patología de la caña de azúcar. (Last development in the pathology of sugar cane.) Insular Expt. Sta. Puerto Rico, Circ. 33:32-36, 1920.

Paper read before the Sugar-Cane Technologists' Association of Puerto Rico. Reviews the work done in sugar-cane pathology and devoted special attention to mosaic disease.

Naturaleza del mosaico de la caña. (Nature of the mosaic disease of sugar cane.) Sugar 25:222-223, 1923.

A discussion of bodies found in mosaic plants.

Annual Report for the Division of Plant Pathology and Botany for the year 1920-21. Insular Experiment. Sta. Porto Rico Ann. Report 1920-21: 52-53, 1921.

Recent development in the study of the nature of mosaic diseases of sugar cane and other plants. Journ. Dept. Agric. Porto Rico 6(3) : 22-27, 1923.

The author reviews the work of Iwanoski, Kunkel and Palm on the intracellular bodies.

Recientes investigaciones en el estudio de la naturaleza del mosaico de la caña de azúcar y otras plantas. (Recent investigations on the studies of the nature of mosaic disease of sugar eane and other plants.) Rev. Agric. Puerto Rico. 9(4) : 9-12, 1922.

Popular diseussion of an article that appeared in Journ. Dept. Agric. Puerto Rico. 6(3): 22-27, 1923.

Artificial Transmission of sugar cane mosaic. Journ. Agric. Res. 46(9) : 821-839, 1933.

The author gives a review of the subject and describes a new and successful method of inoculation. A drop of juice from a diseased plant was placed at the base of the youngest leaf of a young plant. A fine needle was passed horizontally or downward through the juice into the tissues five or six times. The juice could be kept at 4 degrees C. indefinitely without inactivation.

Relative infectivity of mosaic virus extracted from various parts of sugarcane. Phytopathology (Abstract) 24(1):1415, 1934. 


\section{Maublanc, $\mathbf{A}$ [ndré]}

La mosaïque de la canne á sucre. (Sugar Cane mosaic.) Agron. Colon. No. 61, 7 pp. Paris. (Rev. Appl. Ent. Ser. A. 11 : 168.) 1923.

A discussion of the disease with special reference to its transmission by insects.

\section{Maupas, Albert}

Sur la maladie de l' enroulement des feuilles de tomates. (Leaf-roll disease of tomatoes.) Rev. Hort. 94:52-54, 1922. A popular diseussion.

\section{May, D[avid] W[illiam]}

Kavangire in Porto Rico. (A reply to E. W. Brandes.) Facts About Sugar 21: 522, 1926.

Controversial.

Kavangire in Porto Rico. (A reply to F. S. Earle.) Facts About Sugar, 21: 1096, 1926.

Controversial.

\section{May, W.}

Die Rohrzucker-Culturen auf Java und ihre Sefährdung durch die Serehkrankheit. Bot. Zeitung 49:10-15, 1891.

\section{Mayer, $\mathbf{A}[$ dolf] $\mathbf{E}[$ dward]}

Over de mosaikziekte van de tabak: (On the mosaic disease of tobacco.) Woorloopige Meded. Landbouwk. Tijdschr. 1882 : 359-364, 1882.

Over de in Nederland dikwijls voorkomende Mozaikziete der Tabak. (The occurrence of tobaceo mosaic disease in Holland.) Landb. Tydschrift. 31, 1885.

Ueber die Mosaikkrankheit des Tabaks. (Tobaceo mosaic disease.) Landw. Versuchs. Stat. 32:450-467, 1886. (Journ. Mycology (Abstract) 7:382-385, 1894.)

The first important paper on tobaceo mosaic. Believed the disease to be caused by bacteria but failed to isolate an organism that would reproduce the disease. Disease not caused by fertilizers and not carried by the seed.

Ueber die mosaikkranheit des tabaks. Landw. Vers. Sta. 32: 451-467, 1886. 
Heilung der Mosaikrakheit des tabaks. (Curing of tobaceo mosaic disease.) Landwirsch. Versuch. 35:339-340, 1888.

Ueber die Mosaikkrankheit des Tabaks. (Mosaic disease of tobaceo.) Journ. of Mycology 7(4):382-385, 1894.

An extensive abstract in English by Erwin F. Smith of the paper which appeared in Landw. Versuchs. Stat. 32: 450-457, 1886.

Blattrollkrankheit der Kartoffel. (The leafroll disease of potato.) Fuhlings Landw. Zeitg. H. 19-20:474 478, 1916.

Mrc Alpine, D.

Bitter pit investigations. First Progress Rpt. 197 p., 1911-12;

Second Progress Rpt. 224 p. 1912-13; Third Progress Rpt. 176 p., 1913-14; Fourth Progress Rpt. 187 p., 1914-15; Fifth Progress Rpt. 144 p., 1915-16.

Bitter pit in apples and pears: the latest results in preventive measures. Phytopathology 11(9) : 366-370, 1921.

Account of this disease and preventing measures with special reference to breeding measures. (Written before the cause of the disease was known.)

\section{MicCall, Thomas] MI ontgomery]}

The effects of certain cultural practices on the transmission of virus diseases of the potato. Potato Assn. of Amer. Ann. Meeting 16th Proc. 1929-30:161-163, 1930. (Rev. Appl. Mycol. 9: 551, 1930.)

In northern Minnesota spindle tuber gave losses as high as 40 per cent. Other virus diseases less. Gross work on transmission of spindle tuber by cutting knives is confirmed.

\section{Mc Callan, E[rnest] A[lbert]}

Report of seed potato inspection. Bermuda Agric. Dept., Agric.

Bull. 1922: 4-7, 1922.

A record of the amount of leafroll and mosaic in plants grown from the same stock in Bermuda and Nova Scotia.

Bermuda: Eine Krankheit der Lilium longiflorum und die "Aster yellows". (Bermuda: A disease of Lilium longiflorum and the aster yellows.) Inst. Anz. Pflanzenschutz. 1: 65, 1927.

Mosaic disease of sugar cane with special reference to its eradication in Natal. South African Sugar Journ. 12(8) : 483-489, 1928. 
Sugar cane diseases in South Africa. South African Sugar Journ. 13(9) : 573, 575, 577, 579, 1929; 14(6) : 399-407, 1930. (Rev. Appl. Mycol. 9(3) : 202-203, 1930.)

Mosaic and streak diseases are the most important and are described. Resistant varieties are recommended as means of control.

\section{IMc Clean, A[lan] P[ercy] D[ouglas]}

The mosaic campaign. Latest information regarding the position. South African Sugar Journ. 11(5): 297-298, 1927. (Rev. Appl. Mycol. 6: 696. 1927.)

The status of the eampaign at date of publications.

Bunchy-top disease of the tomato. Dept. Agric. South Africa, Sci. Bull. 100, 28 p., 1931.

An extensive deseription of this disease on tomato and its behavior. No insect vectors have been demonstrated in the author's tests. It is readily transmitted artificially and by grafting. It failed to be transmitted to tobacco but it was successfully transferred to Physalis peruviana and back to tomato. Control measures are recommended.

Bunchy top disease of the tomato. Farming in South Africa 6(67) : 275-276, 280, 1931.

Popular account describing the disease. The author states that tomato bunchy-top virus is similar to that of tobaceo mosaic. Explains ways of spreading and gives control measures.

Control of mosaic disease in South Africa. Proc. Fourth Intern. Congr. Sugar Cane Technologists 1932. (Facts About Sugar (Abstract) 27(6):260, 1932.)

It was found practically impossible to eradicate mosaic disease from sugar cane, due to the occurrence of the disease on the grass Setaria Sulcata which is widely distributed in South Africa. The author declares that it has been reduced to a minimum by the planting of immune or highly resistant varieties. (P.O.J. 2878, 2727, 2725 and 2714, Co. 290, and C. H. 64/21.)

Streak disease of sugar eane. South Africa Sugar Journ. 17 (5) : 247, 249, 251, 253, 255, 257, 259, 1933.

Paper read before the South African Sugar Technologists' Annual Congress. The author makes a full account of the present conditions of the disease in South Africa.

The behaviour of the cane variety P.O.J. 213 towards streak disease. Fourth Congress Intern. Soc. Sugar Cane Technologists, Puerto Rico 1932, Bull. 27, 6 p., 1933. 
Studies on the behaviour of streak disease in the P. O.J. 213 sugarcane variety.

\section{Mc Clintock, J[ames] A[lbertine]}

Is cucumber mosaic carried by seed? Science n.s. 44(1144): 786-787, 1916.

Gives evidence that the disease is carried in the seeds.

Peanut mosaic: an investigation of plant disease. Peanut Promoter 1:29, 1917.

Peanut mosaic. Science n.s. 45:47-48, 1917. (Int. Rev. Sci. \& Pract. Agric. 8(5) : 802-803, 1917.)

A brief paper, gives a record of the disease.

Lima bean mosaic. Phytopathology (Abstract) $7(1): 60-61$, 1917.

Spinach blight. Phytopathology (Abstract) 8(1):74, 1918.

\section{\& Smith L[oren] B[arlett]}

True nature of spinach blight and relation of insects to its transmission. Journ. Agric. Res. 14(1) 1-59, 1918.

Gives a deseription and history of the disease and the results of experiments with fertilizers, and methodis of transmission. Demonstrated that the disease was infectious and carried by Macrosiphum solanifolii.

Overwintering of mosaic of annuals. Phytopathology (Abstract) $11(1): 47,1921$.

Peach rosette, an infectious mosaic. Jour. Agric. Res. 24(4): 307-316, 1923.

Gives the results of experimental budding which proves that the disease can be transmitted in this manner.

Cross-inoculation experiments with Erigeron yellows and peach rosette. Phytopathology 21(4) : 373-386, 1931.

Cross-inoculation of aster yellows, peach rosette were made and observed. Several insects were observed as to the capability to transmit those diseases.

\section{Mc Cubbin, W[alter] A[lex]}

Report from the branch laboratory of the Division of Botany. Canada Expt. Farms. Rpts. 1913 : 497-498, 1913. 
The disease of tomatoes. Canada Agric. Expt. Farms. Bull. 35 : 16 p., 1918.

Peach yellows and little peach. Pennsylvania Dept. Agric. Gen. Bull. 382, 16 p., 1924.

A popular discussion of the subject.

Present status of peach yellows in Pennsylvania. Pennsylvania State Hort. Soc. Proc. 66: 75-78, 1925.

Three little known diseases of peach. Pennsylvania State Hort. Soc. Proc. 67:46-50, 1926.

Peach yellows and little peach. Pennsylvania Dept. Agric. Bull. $10(3): 3-16,1927$.

\section{\& Holdridge, F. L.}

Observations on peach yellows Pennsylvania Acad. Sci. 1:, 1927.

Some comments on the virus diseases. Hints to Potato Growers, 1927.

Popular notes.

Peach yellows report 1927. Pensylvania Dept. Agric. Bull. $11(6)$ : 3-25, 1928.

This paper gives the results of inspection and eradication work. Also a discussion of various phases of the problem.

\section{\& Smith F[loyd] $\mathbf{F}$ [ranklin]}

Rate of virus spread in tomato plant. Science n.s. 66(1716): 486-487, 1927.

A short paper giving the results of experiments which indicate that the virus travels through tomato shoots at the rate of from one to two inches per day.

\section{$\&$}

Spread of mosaic virus in tomato plants. Phytopathology (Abstract) 20(1):134, 1930.

\section{\&}

Spread of mosaic virus in tomato plants. Journ. Bact. 19(1): 23, 1930. (Rev. Appl. Mycol. 9:416, 1930.)

The virus travels from one to two $\mathrm{mm}$. per hour but the rate varies with the temperature. 
248 THE JOURNAL OF AGRICULTURE OF THE UNIVERSITY OF P. $\mathrm{R}$.

Report on peach yellows inspection in Pennsylvania in 1929. Plant Disease Reporter 14(4) : 33-37, 1930.

\section{IIc Donald, J[ohn]}

Annual Report of the Mycologist for the year 1922. Kenya Dept. Agric. Ann. Rpt. 1922:111-115, 1924.

Report of the Mycologist for the period April 1st. to Dec. 31, 1921. Kenya Dept. Agric. Ann. Rpt. 1921:123-126, 1925.

Annual Report of the Mycologist for 1928. Kenya Dept. Agric. Ann. Rpt. 1928. (Rev. Appl. Mycol. 8: 632-633, 1929.) Contains a reference to the mosaic of sugar cane in one district.

\section{Mc Kay M[arion] B[ertice]}

Mosaic disease of tomatoes. Oregon Agric. Expt. Sta. Crop. Pest \& Hort. Rpt. 3(1915-1920) : 179-184, 1921.

A popular description.

Potato diseases in Oregon and their control. Oregon Agric. Expt. Sta. Girc. 24:47-51, 1922.

Brief popular notes on mosaic, eurly dwarf, leaf roll, spindle sprout, and net necrosis.

\section{\& Dykstra, Theodore $\mathrm{P}$ [eter]}

Curly top of squash. Phytopathology (Abstract) 17(1):48-49, 1927.

Sugar beet curly top virus, the cause of the western yellow tomato blight. Phytopathology (Abstract) 17(1):39, 1927.

Narcissus and tulip diseases. Oregen State Hort. Soc. Ann. Rpt. 18 : 137-150, 321-323, 1926.

\section{Brierley, Philip, \& Dykstra, Theodore P[eter]}

Tulip "breaking" is proved to be caused by mosaic infection. U. S. D. A. Yearbook $1928: 596-597,1929$.

Brief account on this disorder known as "breaking". Description of methods of inoculation and discussion of insect vectors.

Potato virus diseases: Oregon investigation 1924-1929. Oregon Agric. Expt. Sta. Bull. 294: 40 p., 1932.

\& Dykstra, Theodore P[eter]

This paper gives results of experimental work for six years. Myzus persicae transmits crinkle, rugose, leaf-rolling mosaic and leaf roll but 
not mild mosaic; Illinoia solanifolii (Macrosiphum gei) transmits leaf-rolling mosaic and leaf roll but was not as efficient as some other carriers. It did not transmit mild mosaic, rugose mosaic or crinkle; Myzus (Macrosiphum) pelargonii transmitted leaf-rolling mosaic and leaf roll but did not transmit mild mosaic, crinkle or rugose mosaic. M. circumflexus transmitted crinkle, rugose, mosaic and mild mosaic from diseased to healthy potato under insect-proof eages without insects.

\& Warner, IM. F.

Historical Sketch of Tulip Mosaic or Breaking, The Oldest Known Plant Virus Disease. The Nat. Hort. 12(3) : 179-216, 1933.

A history of this disease and reproductions of old drawings. This is the oldest virus disease of which we have any record. The paper also includes a description of the disease and a very complete bibliography dating back to 1561 .

B. I., \& Blood, H. L.

Virus and virus-like diseases of the potato in the northwest and

their control. U.S.D.A. Circ. 271, 31 p., 1933.

The potato virus diseases studied include mild, crinkle, and rugose mosaic, leaf-roll, witches broom and spindle tuber. Descriptions of them are given and methods of control. Other disorders studied which appears to belong to the virus-disease group were: calico, psyllid yellow and giant hill. Tuber indexing is recommended as the ideal method for eliminating the virus diseases from the seed stock; roguing is also advisable.

\section{McKenny Hughes, A. W.}

Aphis as a possible vector of "breaking" in tulip species. Ann. Appl. Biol. 17(1) : 36-42, 1930.

The author suggests Myzus persicae Sulz. as a vector of the virus that produces "breaking" in tulips, also associated with "red-streak break." Macrosiphum gei Kock possibly carries "break" in a lesser degree and is associated with "white streak".

Aphides as vectors of "Breaking" in tulips. Ann. Appl. Biol. 18(1) : 16-29, 1931.

Experiments are described. Myzus persicae is responsible for the transmission of the disease and Macrosiphum gei to a lesser extent. Two types of "breaking" were distinguished.

Aphids as vectors of "breaking" in tulips II. Ann. Appl. Biol. 21(1) : 112-119, 1934.

The author distinguishes three types of "breaking" e. g. full, self and clotted. Two viruses produced full breaking. Self breaking may be selectively transmitted by the aphis vectors Myzus persicae Sulz. 
and Macrosiphum gei Kock. Self-breaking tulips only transmit selfbreaking. At a certain stage of growth tulips cease to be susceptible to infection.

\section{Mc Kinley, Earl Baldwin}

Filterable virus diseases of plants. Philippine Journ. Sci. 39 (1-4) : 344-367, 1929.

Chapter XIV of this work is devoted to "Filterable Virus Diseases of Plants", which is a very comprehensive review of the subject.

A concept of the ultramicroscopic virus diseases and a classification. Science. n.s. 76(1977) : 449-454, 1932.

A general discussion on virus diseases trying to define and classify them. Although it is not a paper on plant virus disease, it is of interest to students on the subject.

\section{Mic Kinney, $\mathrm{H}$ [arold] $\mathrm{H}[$ all,] \& Larrimer Walter $\mathrm{H}$ [arrison]}

Symptoms of wheat rosette compared with those produced by certain insects. U.S.D.A. Bull. 1137, 8 p., 1923.

Comparative descriptions.

\section{$\mathrm{W}$ [illiam]}

\section{Eckerson, Sophia H[emison,] \& Webb, Robert}

The intracellular bodies associated with the rosette disease and a mosaic-like leaf mottling of wheat. Journ. Agric. Res. 26 (12) : 605-608, 1923. (Phytopathology (Abstract) 13(1):41, 1923.)

The authors describe the intracellular bodies and discuss their possible nature.

Intracellular bodies associated with a mosaic of Hippeastrum Johnsonii. Phytopathology (Abstract) 13(1) : 41-42, 1923.

Investigations of the rosette disease of wheat and its control. Journ. Agric. Res. 23(10): 771-810, 1923.

A description of the disease. The cause is unknown but the disease ean be transmitted by the soil. The active agent is destroyed by soil sterilization.

Certain aspects of the virus diseases. Phytopathology 15(4): 189-202, 1925.

A comparison of characters of the virus diseases of animals and plants. 
A mosaic disease of winter wheat and winter rye. Phyto. pathology 15(8) : 495-496, 1925. (U.S.D.A. Bull. 1361, 10 p., 1925.)

A brief note in which the author states that this disease is not carried in the seed. It is found in the soil.

\section{$\mathrm{H}[\operatorname{arlan}]$}

\section{Webb, Robert W[illiam,] \& Dungan, G[eorge]}

Wheat rosette and its control. Illinois Agric. Expt. Station Bull. 264 : 275-296, 1925.

A deseription of the disease including some eytology. Also studies to determine cause and control.

Factors affecting the properties of virus. Phytopathology 16 (10) : 753, 1926 .

Virus of a high concentration has a higher thermal death point than a virus of a low concentration. Diluted virus becomes more inactivated at room temperature than undiluted virus.

\section{Webb, Robert W[illiam]}

The dilution as a means for making certain quantitative studies of viruses. Phytopathology (Abstract) 16(1):66, 1926.

Virus mixtures that may not be detected in young tobaceo plants. Phytopathology 16(11) : 893, 1926.

Brief report on study of common and yellow mosaic.

Factors affecting certain properties of a mosaic virus. Journ. Agric. Res. 35(1) : 1-12, 1927.

This paper gives a brief review of the literature and the results of experiments with temperature, mixing with extracts from other plants, dilution, ete.

Quantitative and purification methods in virus studies. Journ. Agric. Res. 35(1) : 13-38, 1927.

This paper gives the results of inoculation experiments, purification studies and variability of extracts. "From the results presented it is evident that the methods of culturing and selecting the plant material, and the methods employed in making and manipulating the virus extracts must be standardized just as far as possible to insure reasonably uniform results."

Virus diseases observed by the Allison V. Armour Expedition. Phytopathology (Abstract) 18(1): 155, 1928. 
A "Streak" of tomatoes produced by a disturbing principle from apparently healthy potatoes in combination with tomato mosaic. Phytopathology 18(3):311, 1928.

Brief note giving his observations.

Further studies on the quantitative virological methods. Science N. S. 68(1764) : 380-392, 1928.

Gives improvements on the methods in use and cautions to insure accuracy. Also brief statements as to the influence of light and temperature.

Centrifuging filterable viruses. Science n.s. $67(1732): 271,1928$. Reviews a note by M. S. Marshal (Science n. s. Sept. 2, 1927, page 219 ) and a paper by himself (Journ. Agrie. Res. 35: 13-38, 1927.)

Mosaic diseases in the Canary Islands, West Africa and Gibraltar. Journ. Agric. Res. 39(8): 557-578, 1929. (Rev. Appl. Mycol. 9:260, 1930.)

Gives the results of studies on mosaic in the Canary Islands. Also in West Africa.

Differentiation of virus causing green and yellow mosaics of wheat. Science n. s. 73(1902) : 650-651, 1931.

Wheat mosaic ean be resolved into two distinct types, yellow and green. The rosette is associated with the green but not the yellow type.

A mosaic of wheat transmissible to all cereal species in the tribe Hordeae. Journ. Agric. Res. 40(6):547-556, 1930.

The author records ten species as susceptible to this disease. Each species contains resistant strains. Rosette was found associated with mosaic and is considered a phase of the disease.

Further studies on virus purification. Phytopathology (Abstract) $21(1): 118,1931$.

Four apparently undescribed mosaics which go to tobaceo. Phytopathology (Abstract) 21(1):118, 1931.

\section{IIc Larty, H[arold] $\mathbf{R}$ [oss]}

Suspected mosaic disease of sweet elover. Phytopathology 10 (11) : 501-503, 1920.

A brief note. 
Witches' broom of potatoes. Sci. Agric. 6(11) : 395, 1926.

\section{MIc Lean, W.}

The control of leaf-roll disease in potatoes by the diagnosis of "Primarily infected" tuber. Journ. Agric. Sci. 16(1) : 149157, 1926.

Healthy tubers lose weight when dried more rapidly than primarily infected tubers.

Effect of leaf-roll disease in potatoes on the composition of tuber and "mother tuber". Journ. Agric. Sci. 16(2) : 318$324,1926$.

A chemical study of the disease.

\section{Mic Murran, S[tockton] MI [osby]}

Pecan rosette in relation to soil deficiencies. U. S. D. A. Bull. 756, 11 pp. 1919.

\section{Mc IMurtrey Jr., J[ames] E[dward]}

Effect of the mosaic disease on yield and quality of tobacco with suggestions for control. Maryland Agric. Expt. Sta. Bull. 302:147-158, 1928.

This paper gives valuable data as indicated in the title.

Effect of mosaic disease on yield of tobaceo. Journ. Agric. Res. 38(5) : 257-268, 1929.

Very similar to the preceding paper.

\section{IIc Rae, W[illiam]}

Report of the Imperial Mycologist. India Agric. Res. Inst. (Pusa) Sci. Rpts. 1921-22 : 44-50, 1922.

Mosaic disease of sugar cane in India in 1925. Agric. Journ. India 21(3): 198-202, 1926. (The Planter \& Sugar Manuf. 77(17) : 331-332, 1926. Mundo Azucarero 14(5) : 152-154, 1926. Rev. Appl. Mycol. 5: 695-696, 1926.)

Report about the conditions of sugar-cane varieties in regard to mosaic disease and the spread of it in India. Contains also a con. siderable amount of historical data concerning the disease in India.

Report of the Imperial Mycologist. India Agric. Res. Inst. (Pusa) Sci. Rpts. 1926-27:45-55, 1928. (Rev. Appl. Mycol. $7: 302-304,1928$.

Contains a statement concerning mosaic on sugar-cane seedlings. 
$25 \pm$ THE JOURNAL OF AGRICULTURE OF THE UNIVERSITY OF P. R.

mania]

\& Subramanian, I[ekshminarayanapuram] S[ubra-

A further note on the mosaic disease of sugar Cane. Agric. Journ. India 23(4) : 239-255, 1928. (Rev. Appl. Mycol. 8: 63, 1929.)

A deseription of the disease, its distribution in India and the rosults of varietal tests.

Effect of mosaic on the tonnage and juice of sugar cane in Pusa, Part II. Indian Journ. Agric. Sci. 2 : 378-384, 1932.

The results of carefully controlled plot experiments. The germination, yield, juice and sucrose was lower in diseased than in healthy cane.

Experiment to test the difference in yield between sugar cane with mosaic disease and free from mosaic disease during the season 1930-31 in Pusa. Fourth Cong. Intern. Soc. Sugar Cane Technologist, Puerto Rico, 1932. Bull. 28, 4p., 1933.

Account of observations and results of experiments made by the author.

\section{IMc Rostie G[ordon] P [eter]}

Inheritance of disease resistance in the common bean. Journ. Amer. Soc. Agron. 13(1) : 15-32, 1921.

\section{IIc Whorter, Frank P[aden]}

The nature of the organisms found in Fiji galls of sugar cane. Philippine Agric. 11(4):103-111, 1922. (Louisiana Planter $70: 148-150$, 1923. Rev. Path. Veg. \& Ent. Agric. 10:99, 1923.)

A very careful study of the life history of the organisms which he describes under the name of Phytamoeba sacchari.

The mosaic situation. Philippine Agric. 12(2) : 93-95, 1923. A summary of several papers on mosaic disease.

Cause and control of Fiji disease of sugar cane. Agric. Journ. India. 18:651-652, 1923.

A popular paper.

Further report on rose mosaic in Oregon. U.S.D.A Plant . Disease Reporter. 15(1):1-3, 1931. (Mimeographed).

Description of the disease and wild hosts are given. 
Narcissus "gray disease" is a transmissible mosaic. Oregon Agric. Expt. Sta. Dept. Bot. Tech. Paper 180, 1932. (Florists' Exchange. $79(14): 11,1932$.

Account of the transmissibility and control of nareissus "gray" or mosaic disease.

\section{Weiss, Freeman}

Diseases of narcissus. Oregon Agric. Expt. Sta. Bull. 304, 41 p. 1932.

A brief reference to virus diseases.

Narcissus mosaic symptoms. Phytopathology (Abstract) 22 (12) : 998, 1932.

A preliminary analysis of tulip breaking. Phytopathology (Abstract) 22(12): 998, 1932.

Medalla, M[ariano] G., \& Reyes, G[audencio] II.

Fiji disease of sugar eane. Philippine Farmer 7:3, 5, 1921.

A popular discussion of the subject and recommendations for a domestic quarantine, the use of resistant varieties and disease-free seed.

Fiji disease of sugar cane in the Philippine Islands. Phytopathology 11(6) : 251-252, 1921.

Records of the disease and recommendations for quarantine.

\section{\& Serrano, F[elicísimo] B.}

Losses from mosaic discase. Sugar Cent. \& Planters' News 3 (11) : 543-544, 1922.

Diseases of sugar cane in the Philippines. Sugar Cent. \& Planters' News 4(8):390-392, 1923.

Popular.

Meer, Jikke H. H. van der.

(A study of the virus from the apparently healthy potato variety.

"Green mountain".) Zentral-blatt für Bakteriologie, Parasitenkunde und Infektionskrankheiten, II. Abt. Bd. 87, 1932.

The author gives the results of extensive experiments which she summarizes in part as follows: "The apparently healthy potato variety 'Green Mountain', is carrier of a virus, that produces different symptoms of disease depending on the host and the stage of development of the leaves." "After inoculations with juice of Green Mountaintuber or leaves, two varieties of Capsicum annuиm $L$. reacted by necro- 
sis; Datura Stramonium L., tomato, tobacco and Hyoscyamus niger $L$. by distinct mosaic; Physalis Alkekengi $L$. and Solanum nodiflorum Jack, by mild mosaic; whereas Atropa Belladona L., Solanum Dulcamara L., Solanum Capsicatrum L., and Cyphomandra betacea Sendt. showed no symptoms at all." The author gives much other interesting and valuable data.

Megaw, W. J.

Notes on experiments related to loss of vigor in stocks of potatoes. Journ. Min. Agric. North Ireland. 1:37-45, 1927.

\section{Melchers, L[eo] E[dwards]}

The mosaic disease of the tomato and related plants. Ohio Nat. 13(8) : 149-173, 1913. (Contrib. Bot. Lab. Ohio Univ. No. 74.) Reviews the work of other students and gives the results of his own studies on histology.

A preliminary report on raspberry curl or yellow. Ohio Nat. 14 (6) : 281-288, 1914.

The mosaic or white pickle disease of eucumbers. Kansas State Hort. Soc. Trans. 34: 102-104, 1918.

A description of the disease in greenhouse. The losses are estimated at 20 per cent.

\section{\& Hurley, Fellows.}

Wheat mosaic in Kansas, U.S.D.A. Br. Plant Indus. Rpt. 14: 158, 1930.

Wheat mosaic in Egypt. Science n.s. 73(1882) : 95-96, 1931.

Field observations were made by the author. $\mathrm{He}$ believes that rosette of wheat and barley are associated with mosaic. From observations he concluded that the United States virus diseases of wheat are distinct from those in Egypt.

Plant disease problems in Egypt. Trans. Kansas Acad. Sci. 35: 38-62, 1932.

Brief notes on the progress of the work on the following virus diseases: Wheat mosaie and rosette, mosaic of Vicia faba and Phaseolus vulgaris, mottled and "fern leaf", forms of mosaic on tomatoes, mosaie on pepper (Capsicum annuum), sweet melon and sugar cane, streak on sugar cane and banana bunchy top.

\section{Melhus, Irving $\mathbf{E}$.}

Notes on mosaic symptoms of Irish potatoes. Phytopathology (Abstract) 7(1): 71, 1917. 
Mosaic studies. Phytopathology (Abstract) $12:(1) 42,1922$.

\section{\& Henderson, W. J.}

The yellow dwarf of onions. Phytopathology (Abstract) 19(1): $86,1929$.

\section{Reddy, C[harles] s[teven], Henderson, w. J., \&} Vestal, Figar F[red]

A new virus disease epidemic on onions. Phytopathology 19(1): 73-77, 1929.

A discussion of this disease, including description, estimate of losses. and proof that it is due to a virus.

\section{Mencacci, IM.}

Le malattie delle degenerazione della patate. (The degeneration. diseases of the potato.) Biol. Mens. Inform. Not. Rom. 5. $(7-12): 53-59,1925$.

\section{Mendiola, $\mathbf{N}[$ emesio] $\mathbf{B}[$ lanco], \& Unite, Juan $\mathbf{O}$.}

Sugar cane breeding in the College of Agriculture. The Philippine Agric. 13(3) : 115-128, 1924.

\section{\& Ocfemia, G[erardo] O[ffimaria]}

The work of breeding resistant crop plants at the College of Agriculture at Los Baños. The Philippine Agric. 15(3)117128, 1929. (Rev. Appl. Mycol. 6:43, 1926.)

Contains brief statements concerning work for the control of Fiji disease of sugar eane and bunchy top of Musa textilis.

\section{Menéndez Ramos, R[afael]}

El suelo no puede ser responsable del matizado de la caña. (The soil can not be responsible for the mottling of sugar cane.) Rev. Agric. Puerto Rico. 11(3) : 13-20, 1923.

The soil is not the cause of the disease.

Sigamos con el matizado. (Let us continue with the mottling disease.) Rev. Agric. Puerto Rico. 11(5) :23-28, 1923.

Sugar cane disease. Ins. Expt. Sta. Puerto Rico Ann. Rpt. 192223 : 21-22, 1923.

A brief record.

La cal como enmienda (Lime as an amendment). Insular Expt. Station, Porto Rico. Circ. 74, 17 p., 1923. 


\section{THE JOURNAL OF AGRICULTURE OF THE UNIVERSITY OF P. R.}

Discussion on the agricultural uses of lime. The author discusses the popular belief that lime is a cure of sugar-cane mosaic. He declares that lime is not a eure for the disease.

Estudios sobre el mosaico de la eaña. Movimiento del virus a través del tallo en el caso de infecciones secundarias. (Studies on sugar cane mosaic disease. Movement of the virus through the stalk in cases of secondary infections.) Rev. Agric. de Puerto Rico. 13(4) : 219-226, 1924 (Rev. Appl. Mycol. 4 : 244. Louisiana Planter \& Sugar Manuf. 73(25):488-489, Rev. Agric. Com. \& Trab. Cuba 7(5):31-33, 1925.)

All the cuttings from a stalk of eane on which only a part of the leaves are mottled, will probably produce diseased plants.

Mosaic disease and methods of control. Planter \& Sugar Manuf. 75(25) : 487-498, 1925. (Rev. Appl. Mycol. 5:329, 1925.) A popular discussion of the subject.

La enfermedad mosaico y los métodos de combatirla. (The mosaic disease and methods to control it.) El Mundo Azucarero $13(8): 241-245,1926$.

A translation of the previous eitation. Planter \& Sugar Manuf. 75: 487-489. 1925.

The control of sugar cane mosaic in the West Indies. Ref. Book of the Sugar World (The Planter \& Sugar Manuf.) 5 : 38-41, 1927.

A short paper giving extensive data on field studies.

El comportamiento de la enfermedad del mosaico en las variedades POJ-2714, 2725, y 2727 en la Provincia de Oriente. (Behavior in regard to the mosaic disease of the sugar cane varieties POJ-2714, 2725, and 2727 in the Province of Oriente.) Suplemento de la Memoria de la Segunda Conferencia Anmal Asociación de Técnicos Azucareros de Cuba. Dec. 1928, p. 35-62, 1928. (Planters \& Sugar Manuf. 81(6) : 101-104, 1928.)

The calculation of mosaic infection in highly resistant canes.

Int. Sugar Journal (Abstract) 35(419):428, 1933.

Paper presented at the Sixth Annual Conference of the Association of Sugar-Cane Technologists of Cuba, held in December, 1932. The author grouped the varieties according to the behaviour of the disease on each, thus P. O.J. 2725 and Java-Barbados hybrids derived from it in one group and B. H. 10(12), S. C. 12(4) and Cristalina in 
another. He establishes the stalk unit as measurement in calculating mosaic infection against the stool unit, which he declares is misleading in determining the relative commercial immunity. He gave a table comparing the results of both unit basis. He states that incidentally, it may be noted that many of the crosses of P.O.J. 2725 and S. C. 12(4) are more resistant than the female parent in spite of the fact that the male parent is very susceptible. Further, the two varieties M 28 and F. C. 916 show a relatively high susceptibility in contrast with a practical immunity recorded in Puerto Rico.

\section{IMenezes Sobrino, A.}

O mosaic da canna. (The mosaic de cane.) Bol. Agric. Bahia (Brazil) 1926: 25-28, 1926.

\section{Merkel, L[udwig]}

Beiträge zur kenntnis der Mosaikkrankheit der Familie der Papilonaceae. (Contribution to the knowledge of the mosaic disease of the family of the Papilonaceae.) Zeitschr. für Pflanzenkrankn (Pflanzenpath.) u. Pflanzenschutz. 39(8-9):289347, 1929. (Rev. Appl. Mycol. 9(2) : 120-121, 1930.)

This paper contains a great deal of data concerning mosaic of legumes.

\section{Merkenschlager, $\mathbf{F}[$ ritz $]$}

Zur Biologie der Kartoffel. II Mitteilung. Zur Pathologie der Blattrollkrankheit. (On the biology of the potato. Note II. On the Tathology of the leaf-roll disease.) Arb. Biol. Reichsanst. fïr Land-und Fortwirtsch. 17(4):345-376, 1929. (Rev. Appl. Mycol. 9(2) : 122-123, 1930.)

A discussion of the histology of the diseased plant. Also a study of soil relationships.

Zur Biologie der Kartoffel. (On biology of the potato) 4 Mitt. zur Patholngie des Abbaus. Arbeit. Biol. Reichsanst. 17: 435-458, 1930.

Kartoffelprobleme. Die Schwarzfärbung des Kartoffelfleisches. Das Abbauproblem. Uber die sog. Viruskrankheiten der Kartoffel. Kartoffelban, 14:61-63, 73-75, 1930.

\section{\& Klinkowski, M[aximilian]}

Zur Biologie der Kartoffel. VI Mitteilung. Der Kückzug der Kartoffelsorte Magnum Bonum nach Skandinavien in Lichte der okologischen Abbautheorie. (On the biology of the potato. Note VI. The retreat of the potato variety Magnum Borum into Skandinavia in the light of the ecological de- 
generation theory.) Arb. Biol. Reichsanst. für Land-und Fortwirtsch. 18(4) : 431-463, 1931.

Comparison of the potato variety in regard to its behaviour in Ger. many and Seandinavia.

Neue Untersuchngen über die Ursache der Degeneration der Kartoffel. (New investigations on the cause of degeneracy of the potato.) Forschungen u. Fortschritte 8:58, 1932.

\section{Merrill, $\mathbf{E}[\mathrm{lmer}] \mathrm{D}[\mathrm{rew}]$}

Breeding sugar beets for resistance to curly top. California Agric. Expt. Sta. Ann. Rpt. 1928-29: 64, 1929. (Rev. Appl. Mycol. 9:424, 1930.)

Notes in this report of the work done by the corresponding department.

\section{Meulen, J. G. J. van der}

Voorloopig onderzoek near de specialisatie en de infectiebronnen der mosaiekziekten van landbouwgewassen. (Preliminary investigations in the specialization of infection process of mosaic disease of cultivated plants.) Tijdschr. Plantenz. 34(5) : 155-176, 1928. (Inst. Phytopath. Lab. Mycol. en Ardappelonderzoek Meded. 35: 155-176, 1928. Zeitschr Pflanzenkrankh. 38:326-328, 1928.)

This paper gives the results of inoculation experiments.

Meyer, F. H.

Die Kräuselkrankheit der Kartoffel. (The curl disease of the potato.) Ill. Landw. Zeitg. 42:295, 1922.

Meyer, H[ans]

Das Chlorose-und Panaschürenphänomen bei Chlorellen. Beih. Bot. Centralbl. 49: 496-566, 1932.

\section{Millbraith, D[avid] G[allens]}

Mosaic diseases of plants. California Cultivator 62:541, 1924. Popular.

Plant Pathology. California Dept. Agric. Monthly Bull. 17 (12) : 683-687, 1928. (Rev. Appl. Mycol. 9(1) : 23, 1930.) Virus diseases of roses are reported.

Infectious chlorosis of the rose. Western Florist 13(29):2930, 1930. 
A discussion of the reported infections chlorosis of the rose.

California Dept. Agric. Monthly Bull. 19(8) : 535-544, 1930.

No proof of the presence of an infective material has been presented. The author agrees that if the condition is a specifie disease then it differs from all other known virus diseases.

\section{Miles, Herbert W[illiam]}

Potato leaf-curl. Kirton Agric. Inst. Ann. Rpt. 1923:33-37, 1923.

Data on yields.

\section{Miles, L[ee] E[llis]}

The mosaic of sugar eane in Mississippi. Mississippi Agrie. Expt. Sta. Bull. 191, 11 p. 1920.

Gives symptoms, distribution, quarantine and control measures.

\section{Milhoffer, $\mathbf{S}$.}

Die mosaikkrankheit des tabaks. (The mosaic disease of tobacco) D. Landw. Presse 30:600, 1903.

\section{Miller, Justus}

Northern Ontario seed potato trade. Potato Mag. 1:33, 34, 1919.

\section{Miller, P[hilip] \& Martyn, T[homas]}

Gardeners and Botanists' Dictionary. 4: (Under Solanum). 1807.

\section{IVilward, J[ames] G[arfield]}

Mosaic control by tuber indexing methods applied to the Triumph variety. Proc. Ann. Meetg. Potato Ass'n Amer. 14 : 88-91, 1928.

Mitra, III.

Disease of plants. Impt. Inst. Agr. Res. Pusa Sci. Rept. 192930: $58-70,1930$.

Reports sterility of "rahar" Cajanus indious of possible virus origin.

\section{IIogendorff, $\mathbf{N}[$ ico $]$}

Fern-leaf of tomato. Phytopathology 20(1) : 25-46, 1930. (Rev. Appl. Mycol. 9:417, 1930.)

The typical fern-leaf symptoms were not produced with the virus from tomato and tobaceo mosaic plants. It was rarely produced by artificial inoculation with cucumber mosaic and regularly by Myzus persicae which had fed on mosaic cucumber plants. 


\section{Molisch, Hans}

Das Plasmamosaik in den Raphidenzellen der Orchideen Haemaria and Anoectochilus. (Plasma mosaic in raphid cells of the orchids Haemaria and Anoectochilus.) Sitzungsher. K. Akad. Wiss. Wien (Math.-Nat Kt.) 126:231-242, 1917.

\section{IMolz, E.}

Auftreten der Mosaikkrankheit bei zuckerrüben. (The mosaic disease threat to sugar beets.) Landw. Wachenschr. Sachsen u. Anhalt $28: 637,1926$.

Mosaikkrankheit der Zukerrübe eine in Deutschland neue und gefährliche Zuckerrübenkranheit. (Mosaic disease of sugar beet a new and dangerous disease of sugar beet.) Deutsch. Landw. Presse 53(40):501, 1926. (Landw. Wochenschr. Prov. Sachsen u. Anhatt 28:688-689, 1926.)

Eine neue ud gefährliche Zuckerrübenkrankheit. Die Mosaikrankheit der Zuckerrübe. (A new and dangerous disease of sugar beet. The mosaic disease of sugar beet.) Die Umsehan 31:293-296, 1927.

\section{Moore, E[nid] S[tella]}

Diseases of Virginian tobaceo in South Africa. Journ. Dept. Agric. Union S. Africa. 12:428-455, 1926.

Mosaic of Virginia tobaceo. Farming in South Africa. 1(12): $450-452,1927$.

A popular discussion.

A virus disease of tobacco in South Africa. Nature 129 (3258): 544, 1932.

The disease resembles but is not the same as ringspot. It can be transmitted by grafting and by thrips (Frantcliniella sp.) and rarely by needle punctures but not by the common green aphids. It appears to be the same as the spotted wilt of the tomato in Australia and virus diseases of Datura Stramonium, Physalis spp. and Nicandra physalodes.

The kromnek or Kat River disease of tobaceo and tomato in the East Province (South Africa). South Africa Dept. Agric. Sci. Bull. 123, 28 p., 1933.

Extensive account of this virus disease of wide-spread occurrence in South Africa. 
Important to tobaceo growers. The erinkly dwarf menace of tobacco. Farming in South Africa 8(88): 276, 1933.

Popular notes warning the tobaceo growers about the crinkly dwarfdisease of tobaceo, practically unknown in South Africa a few years ago. Symptoms, etiology and control measures are given.

Moquette, J. P.

Sets over Sereh en over de Gelestrepenziekte. Arch. voor de Java Suiker Indus. 2:346-356, 1894.

\section{IMordaunt, Charles}

Experiments in practical agriculture. Young's Ann. Agric. 14: 444-450, 1790.

Reference to a potato disease which may be due to a virus.

\section{Mori, Nello}

Sulla nature dei filtrabili. (The nature of filterable virus.) Reale Inst. d'incoraggiamento di Napoli, n. d.

Morren, E.

Contagion de la panachure. (Contagion variegation) Belg. Hort. 20: 14-19, 1870.

Historical value only.

\section{Morris, $\mathbf{H}$ [arry] $\mathbf{E}[$ lwood]}

Virose or degeneration disease of potatoes in the northwest.

Proc. Ann. Meeting Potato Ass'n Amer. 15:199-203, 1929.

\section{\& Young, $\mathbf{P}[$ aul] $\mathbf{A}[11$ en $]$}

Potato diseases in Montana. Montana Agric. Expt. Sta. Bull. 227, 51 p., 1930.

The object of this paper is to facilitate the identification of potato diseases. Among those described and tabulated there are a considerable number of virus diseases,

Morse, E. W.

On the power of some peach trees to resist the disease called "Yellows" Bul. Bussey Inst. 3:12, 1901.

\section{IIorse, Stanley F[letcher]}

Mosaic neglect dangerous. Facts. About Sugar 19(2) : 42, 1924.

\section{IMorse, W[arner] J[ackson]}

Potato disease in 1907. Maine Agric. Expt. Sta. Bull. 149: 289-330, 1908. 
264 THE JOURNAL OF AGRICULTURE OF THE UNIVERSITY OF P. R.

Observations upon a yellow disease of the fall dandelion. Science n.s. 28(715) : 348, 1908.

Record of the occurrence of a disease on Leontodon autumnale Linn. in Maine, which the author compares with aster yellows and of course has the characteristics of a virus disease.

Recent progress in potato diseases work in Maine. Agric. of Maine, 1916, p. 246-258, 1916.

\section{Morstatt, $\mathrm{H}$ [ermann Albert]}

Uebersicht über die Krankheiten und Schädling der Kulturpflanzen. (Review about diseases and pest of cultivated plants.) Der Pflanzer p. 184-194, 1913.

Notes on virus diseases of cassava and peanuts.

Die Degeneration bei unseren Kulturpflanzen. (Degeneration in our crop plants.) Blätt Pflanzenbau. u. Pflanzenzücht. $1: 49-51,1923$.

Viruskrankheiten der Pflanzen. (Virus diseases of plants.) Pflanzenbau 1:57-58, 1924.

Entartung, Attersschwäche und Abban bei Kulturpflanzen, insbesondere der Kartoffel. (Degeneration, senile decay, and running out of cultivated plants, especially the potato.) Verlag. Dr. F. P. Datterter \& Co., Freisiug-München, 74 p. 1925.

Der gegenwärtige Stand unserer kenntnis der Degeneration. Angeu. Botanik 13:81-83, 1931.

IMosséri, V[íctor IVI.]

La chlorose de la canne á sucre en Egypte. (Sugar cane chlorosis in Egypt.) Bull. Inst. Egypte 3:1-12, 1921. (Bull. Union Agric. Egypte 18:75-86, 1921.

\section{IIottet, S[éraphin Joseph]}

Dégénérescence de la Pomme de terre par le semis. (Degeneration of the potato by the seed.) Journ. Agric. Pract. 31:1, 1917.

La dégénérescence des pomme de terre. (Degeneration of potato.) Journ. Agr. Pract. 31:327-329, 1918. 
La dégénérescence des pomme de terre. (Degeneracy of potatoes.) Journ. Agric. Pract. n.s. (France) 33(14) : 237-239, 1920.

Moutia, A.

Sur un des modes de transmission de la mosaïque du tabac. (A manner of tobaceo mosaic transmission.) Rev. Agric. Ile Maurice 40:179-180, 1928.

Muir, Frederick Arthur Godfrey, \& Swezey, Otto H[erman]

Entomology. Report Comm. Experiment Station. Hawaii Sugar Planters' Association 1925-26: 16-29, 1927. (Rev. Appl. Ent. ser. A 15 : 431, 1927.)

IVulder, $\mathbf{E}[\mathrm{mile}]$

Cultivation of tobaceo in Sumatra. U. S. D. A Div. Veg. Phys. \& Path. Report 58, 1898.

Müller,

Vechselseitige Uebertragbarkeit der verschiedenen Viruskrankheiten des tabaks, der tomate und der Kartoffel innerhalb der Famile der Solanaceen. Inaugural dissertation, Bonn. 72 p., 1930.

IVuller, D.

Die assimilation der blattrollkranken kartoffelpflanzen. (The assimilation of leaf roll-diseased potato plants. Planta. 16 (1) : 10-15, 1932 .

The stomatal apertures were narrower in diseased than in healthy plants, the respiratory intensity was equal but the carbon dioxide as. similation was much less in the diseased plants.

IIuller, $\mathbf{H}[\mathrm{ans}] \mathbf{C}[\mathrm{arl}$,$] \& Stömer, \mathbf{K}[\mathrm{urt}]$

(Investigations in plant diseases.) Ber. Agric. Chem. Kentroll u Vers. Stat. Pflanzenkrank. Prov. Sachsen, p. 71-84, 1910. Muller, H. R. A.

Mosaickziekte bij cassave. (Mosaic disease of cassava.) Inst. vor Plantenziekten Bull. 24:1-17 1931.

Manihot utilissima at Buitenzorg, Java, showed symptoms of mosaic.

Müller, K[url] Rudolf

Eine neue Rübenkrankheit. (A new beet disease.) Deutsche Landw. Presse 56(33) : 469-470. 1929 (Rev. Appl. Mycol. 9 (3) : 153-154, 1929. D. Deutsche Zuckerindustr. 54:11681169, 1929. Lcndw. Wochenschr., Halle 87:636-637, 1929.) 


\section{IIüller, W.}

Mosaikkrankheit su Himbeeren. (Mosaic Disease of raspberry.) Mach-richenbl. Deutsch. Pflanzenschutzd. 7(7):65-66, 1927.

\section{Mulvania, Maurice}

Cultivation of the virus of tobacco mosaic by the method of Olitsky. Science 62(1593): 37-38, 1925.

The author conducted tests by the methods given by Olitsky but failed to confirm his results.

A special application of collodion sacs (Tobaceo mosaic). Abstracts of Bact. 9(1):11-12, 1925.

The destructive action of certain bacteria on the virus of tobaceo mosaic. Journ. Bact. 11(2): 98, 1926.

Dialysability of the virus of tobaceo mosaic. Phytopathology 16(11) : 853-872, 1926.

Direct sunlight destroyed 90 per eent in 36 hours. Ultra-violet rays gave complete inactivation in one hour. X-Rays had no effect. $80^{\circ}$ C. for 20 days did not completely inactivate. Complete inactivation by $88^{\circ}$ to $90^{\circ}$ C. for 10 minutes. Was not recovered from blood stream of a rabbit. Was inactivated when mixed with blood of a rabbit. Can pass through certain collodion saes but not through others. Certain bacteria are destructive to it.

Studies on the nature of the virus of tobaceo mosaic. Phytopathology 16(11) : 853-871, 1926.

Root inoculation with the virus of tobacco mosaic. Journ. of Bact. (Abstract) 19(1):23-24, 1930. (Rev. Appl. Mycol. 9: 414, 1930.)

This paper gives the results of efforts to inoculate tobacco plants through the roots, all of which were negative. Inoculations through the leaves gave 80 to 90 per cent positive infections.

\section{Mumford, Edward Philpott}

On the curly top diseases of the sugar beet: A biochemical and histological study. Summary of results.. Ann. Appl. Biol. 17 (1) :28-35, 1930. (Rev. Appl. Mycol. 9:573, 1930.)

The sap of the resistant strains is more concentrated in electrolytes and less concentrated in non-electrolytes and total solids. With one exception the leaves were more acid. The disease caused a decrease 
of sugar in both leaves and roots of resistant strains, but in the susceptible strains it caused an increase in the leaves and a decrease in the roots. The amount of sugar may explain the preference of the the insect for the susceptible plants. Phloem necrosis is a symptom of curly top.

The cuticle and epidermis are thicker in the resistant than in the susceptible plants.

\section{Muncie, J[esse] H[oward]}

The relation of cucurbit mosaic to wild catnip. Proc. Iowa Acad. Sci. $29: 346,1922$.

Yellow dwarf and moron disease of potato in Michigan. Proc. 18th Ann. Meeting Potato Assoc. Amer. 1931:70-73, 1932.

Field studies and yield of potatoes with yellow dwarf. A description of the moron disease.

\section{Mungomery, R. W., \& Bell, Arthur F[rank]}

Fiji disease of sugar cane and its transmission. Queensland $\mathrm{Br}$. Sugar Expt. Sta. (Div. Path.) Bull. 4, 28 p., 1933.

The history and distribution of the disease, symptoms and a full discussion of experimental studies which led to the discovery that the disease is transmitted by Perkinsiella saccharicida.

\section{Muravjev, V. P.*}

Die mosaikkrankheiten der Zukerrübe. (The mosaic disease of sugar beet.) Saatzuchtabt. Allruss. Zuckertrust, $280 \mathrm{p}$. 1930.

Mozaichnye Bolezni Sakharnoi Svekly. (Mosaic disease of the sugar beet.) Kiev., S.S.U. Soiuzsakhara 286 p., 1930.

This work includes contributions from several workers on the subjeet which are inserted in this bibliography under their corresponding names.

(Materials for studying the mosaic of the sugar beet.) In his Mozaichnye Bolezni Sakharnoi Svekly (Mosaic disease of sugar-beet.) Kiev, S. S. U. Soiuzsakhara p. 113-130, 1930. (English Abstract p. 128-130.)

Description of the behavior of the disease and its effect on yields. No resistant variety has been found.

(Diagnosis of the mosaic diseases of the sugar beet.) In his Mozaichnye Bolezni Sakharnoi Svekly (Mosaic diseases of

*Also-Muraviov, V. P. 
268 THE JOURNAL OF AGRICULTURE OF THE UNIVERSTTY OF P. $\mathbf{R}$.

sugar beet.) Kiev, S.S.U. Soiuzsakhara p. 131-140, 1930. (Eng. Abstract p. 138-140.)

"A decimal system has been adopted for economy of energy and time in expressing the appearances of designated areas descriptively in the case of mosaic plant surfaces."

(General sketch of mosaic of sugar beet.) In his Mosaichnye Bolezni Sakharnoi Svekly (Mosaic diseases of sugar beet.) Kiev. S.S.U. Soiuzsakara p. 179-262, 1930. (English translation p. 221-261.)

Review of the publications on sugar-beet mosaic in Russia and elsewhere.

\section{Murphy, Paul A[loysius]}

Mosaic disease of potatoes. Agric. Ga\%. of Canada. 4:345-349, 1917.

The economic importance of mosaic of potatoes. Phytopathology (Abstract) 7(1) :72-73, 1917.

\section{\& Wortley, E[clward] J[ocelyn]}

Determination of the factors inducing leaf-roll of potatoes, particularly in northern climates. Phytopathology 8(4):150154, 1918.

Recommends that varieties should be separated by spaces of six feet.

Disease of the potato. Nova Scotia Fruit Growers' Assoc. Ann. Rpt. 54:180-190, 1918.

Potato inspection service. Agric. Gaz. of Canada 6(3):1-7, 1919.

Some constitutional diseases of the potato. Canada Hort. 42 (1) : 9, 1919.

New or little-known diseases of potatoes which eause runningout of seed. Phytopathology (Abstract) 10(5) : 316-317, 1920.

\section{\& Wortley, E[dard] J[ocelyn]}

Relation of climate to the development and control of leaf-roll of potato. Phytopathology 10(9): 407-414, 1920.

Gives the results of planting in different places and recommends the use of seed from disease-free districts. 
Investigations of potato diseases. Canada Expt. Farms. Bull. 44, 2 ser., 86 p., 1921.

Some recent work on leaf-roll and mosaic. Roy. Hort. (London). Int. Potato Conf. Rpt. 1921: 145-152, 1922.

Gives the results of studies with potato leaf-roll and mosaic on starch translocation and climate.

Leaf-roll and mosaic, two important diseases of potato. Ireland Journ. Dept. Agric. 22 : 281-284, 1922.

Leaf-roll and mosaic of the potato in Ireland. Journ. Nat. Inst. Agric. Bot. 1: 47-50, 1922.

A description of symptoms and results of experiments with insects.

On the cause of rolling in potato foliage; and on some further insect carriers of the leaf-roll disease. Sci. Proc. Roy. Dublin Soc. $17(20): 163-184,1923$

The author reports an excess accumulation of starch in the leaves as a constant symptom of leaf-roll. The disorganization of the phloem was found in plants that had been attacked by Phytophthora and by eel-worms.

Virus diseases of potatoes. Nature (London) 112(2808) : 293, 1923. (Brit. Ass'n Adv. Sci. Rpt. (Abstract) 91:492, 1923.)

Investigations on the leaf-roll and mosaic diseases of the potato. Ireland Journ. Dept. Agric. \& Tech. Instruction 23(1) : 20-34, 1923.

A brief history of these diseases with the results of the studies on the influence of environment and on insect vectors.

\& IIckay, Robert.

Investigations on the leaf-roll and mosaic diseases of potato. Ireland Journ. Dept. Agric. 23(4) : 344-364, 1924.

It appears that the transmission of the viruses is not due to aphids alone. There is a discussion of symptoms for the purpose of distinguishing diseases which are confused.

Virus diseases of potatoes. British Assoc. Adv. Sci. Rpt. (Ahstract) $1923: 492,1924$.

\section{\& Mckay, Robert}

Investigations on the leaf-roll and mosaic diseases of the potato. Ireland Journ. Dept. Agric. \& Lands. 25(2) : 138-154, 1925. 
Investigations on the leaf-roll and mosaic diseases of the potato. Irish Free State Dept. Lands \& Agric. Journ. 26(1):1-3, 1926.

Methods for investigating the virus diseases of the potato and some results obtained by their use. Sci. Proc. Roy. Dublin Soc. 18(10-16) : 169-184, 1926.

The author describes methods and gives the results of transmission experiments. Four insects were found to be carriers: Myzus persicae, M. pseudosolani, Macrosiphum solanifolii, and Calocoris bipunctatus.

\&

Investigations on the leaf-roll and mosaic diseases of potato. Irish Free State Dept. Lands \& Agric. Journ. 26(4) : 295305, 1927.

The insect vectors of the leaf-roll disease of potato. Sci. Proc. Roy. Dublin Soc. 12(20-28):341-353, n. s., 1929. (Rev. Appl. Mycol. 9(3): 197-198, 1930.)

This paper is an extension of previous studies on this subject.

$\&$

La production d'un "crinkle" des pommes de terre par un mélange de virus. (The production of "crinkle" of potato by a crossing of virus.) Rapp. Deuxieme Cong. Intern. Path. Comp. 1:448, 450, 1931.

Based on three years' experiments the authors state that potato crinkle was produced when simple mosaic was introduced into plants carrying a particular latent virus. The synthetic crinkle thus produced persisted in a form indistinguishable from natural crinkle. During five years experimentation no difference in other respects has been revealed between the two diseases.

A critical review of some recent work on the occurrence of virus complexes in the potato. Sci. Proc. Roy. Dublin Soc. n.s. 20 (18) : 193-210, 1932.

\section{\& IMcKay, Robert}

The compound nature of crinkle, and its production by means of a mixture of viruses. Sci. Proc. Roy. Dublin Soc., 20 (20) : 227-247, 1932.

This paper is the result of three years' work which indicate the compound nature of this disease. 
\&

A comparison of some European and American virus diseases of the potato. Sci. Proc. Roy. Dublin Soc. 20(27) :347-358, 1932 .

These studies were made for the purposes of determining the diseases that were common to both continents and the diseases that are distinct.

Murray, J. C.

Report of Field Assistant. Australian Sugar Journ. 16:607609, 611, 1924.

Varietal resistance to mosaic disease in sugar cane.

\section{IIurray, P[ercival] W[aterhouse]}

Investigations on the leaf-roll and mosaic diseases of potato. Ireland Journ. Dept. Agric. 25: 1-8, 1926.

Sugar-cane diseases, Jamaica. Jamaica Dept. Agric. Ann. Rpt. 1920 : 13-14, 1920.

Agricultural Experiments. Sugar-cane mosaic disease. Jamaica Dept. Agric. Ann. Rpt. 1923:12-14, 1924. (Rev. Appl. Mycol. $4: 65,1924$.)

Field experiments in the control of mosaic disease of Jamaica. 1923-25, Jamaica Dept. Agric. Microb. Circ. 6: 16-37, 1926.

\section{Murton, W. A.}

Environmental influences in the pathology of Solanum tuberosum. Journ. Wash. Acad. Sci. 3(7) : 1913.

\section{Musschenbroek, S. C. van}

Gele Strepenziekte (Yellow stripe disease.) Circ. No. 42, der Soerbaijasche Vereeing van 16. Oct. Bl. 327, 1892.

The first record of the mosaic disease of sugar cane.

Beschrijving van twee tot dusverre in West-Java onbekende sietziekten. (Deseription of two unknown diseases in West Java up to the present.) Bijlage Arch. v.d. Java Suiker Indus. Overdruppen, p. 113-118, 1893.

\section{IMyers, J[ohn] G[olding]}

Dry-season studies of cane Homoptera at Soledad, Cuba. Contribution Harvard Inst. Trop. Biol. \& Med. 3:69-110, 1926. (Rev. Appl. Entom. ser. A. 14:497-498, 1926.) 
272 THE JOURNAL OF AGRICULTURE OF THE UNIVERSITY OF P. K.

\section{Nakata, K., \& Takimoto, s.}

(Diseases of cultivated plants in Korea.) Journ. Agric. Expt. Sta. Govt. Gen. Chosen 15, 146 p., 1928.

Narasimhan, III. J.

Note on the occurrence of intracellular bodies in spike disease of sandal (Santalum album Linn.) Phytopathology 18(9): 815-817, 1928.

The author reports the finding of intracellular bodies which supports the virus theory of Coleman.

Cytological investigations on the spike disease of sandal Santalum album. Phytopathology 23(2): 191-202, 1933.

The author describes the results of his cytological studies on spike disease of sandal. He gives special attention to the intracellular bodies observed, describes and compares them.

Narasimhamurthy, N., \& Sreenivasaya, N.

Contribution of the study of spike disease of sandal (Santalum album Linn.) VI. Nitrogen metabolism in healthy and spiked leaves. Journ. Indian Inst. Sci. 12A(10) : 153-163, 1929.

\section{Neal, David C[arleton]}

Phony peaches: A disease occurring in Middle Georgia. Phypathology 10:106-109, 1920.

A description of the disease.

\& Wallance, J. IV.

Sweet potato mosaic. Mississippi State Plant Bd. Quart. Bull. 4: 6-10, 1924.

\section{\& Barker, H[enry]}

Important tomato diseases of Mississippi. Mississippi State Plant Bd. Quart. Bull. 4(1) : 7-24, 1924.

Needham, Charles W.

The breaking of tulips. Garden (London) 89:599-600, 617618, 1925.

Popular account of the disease.

The breaking of tulips. Gard. Chron. 79(3) : 298-299, 1926.

Abstract of lecture before the Wakefield Paxton Society describing the disease.

Breaking in tulips. Gard. Chron. 92:44-45, 1932. 


\section{Neger, F[ranz] W[ilhelm]}

Die Blattrollkrankheit der Kartoffel. (Leaf roll disease of potato.) Deut. Landw. Presse 45(76):469-470, 1918.

Die Blattrollkrankheit der Kartoffel. (Potato leaf-roll disease.) Ztschr. Pflanzenkrank. 29(1-4) : 27-48, 1919.

The author discusses the etiology of the disease and the physiology of the plant, also the translocation of stareh in sound and diseased potatoes.

Gesichtspunkte für die Bekämpfung der Blattrollkrankheit der Kartoffel. (View points in the fight against the leaf roll disease of potatoes.) Der Kartoffelbau 3(11) ; 1919.

(Control of potato leaf-roll.) Sachs. Landw. Forstwischr. 63. (27) : 271-272, 1920.

\section{Nelson, Ray}

Transference of the bean-mosaic virus by Macrosiphun solanifolii. Science n. s. 56:342-344, 1922.

Gives the results of studies which indicate that $M$. solanifolii is the carrier of the virus.

The occurrence of protozoa in plants affected with mosaic and related diseases. Michigan Agre. Expt. Sta. Tech. Bull. 58, 30 p., 1923. (Phytopathology (Abstract) 13(1):41, 1923.)

A histological study which leads to the belief that the disease is due to a protozoan closely related to Leptomonas.

Chrysanthemum yellows, a new disease in the greenhouse. Michigan Agric. Expt. Sta. Bull. 7(4) :157-160, 1925.

Cytological and biological investigations of bean mosaic. Journ. Bact. (Abstract) 19(1):22, 1930. (Rev. Appl. Mycol. 9(7): 423, 1930. Phytopathology $20: 133,1930$.)

The author reports the finding of bacteria in the chloroplasts, cytoplasm, phloem, xylem, and parenchyma tissues. The chloroplasts are destroyed and the bacteria found in the plastid detritus.

Infectious chlorosis of the rose. Phytopathology (Abstract) 20 (1) : 130, 1930.

Correlative studies on the bacteriology of bean mosaic and seed transmission of the virus. Phytopathology (Abstract) 21(1): 116, 1931. 
Investigations in the mosaic disease of bean (Phaseolus vulgaris) Michigan Agric. Expt. Sta. Tech. Bull. 118; 71 p., 1932.

The disease reported from Russia by Iwanowski in 1899, from United States by Clinton in 1908, attacks all commercial varieties and $P$. vulgaris var. humilis, $P$. acutifolium var. latifolius, $P$. angularis, P. coccinelus, Vicia faba and Vigna sesquipedalis. It is transmitted by Macrosiphum solanifolii (M. gei) and the leaf hopper, Empoasca fabae.

\& Down, E. E.

Influence of pollen and ovule infection in seed transmission of bean mosaic. Phytopathology (Abstract) 23(1) : 25, 1933.

\section{Neuwirth, F[rantisek]}

Die Kräuselkrankheit der Zuckerrübe. (The curling disease of sugar beet.) Rudschau, Zeitschr. f. Zuckerind. Prag. 4, 14 p., 1926.

\section{Newcombe, Frederick C[harles,] \& Lee, H[enry] Atherton}

The cause of sectional chlorosis of sugar cane. Hawaii Planters' Rec. 31 : 125-128, 1927.

\section{Newhall, Allan G[oodrich]}

Seed transmission of lettuce mosaic. Phytopathology 13(2): 104-106, 1923.

This paper gives evidence that this disease is carried in the seeds.

Newman, C[harles] C[arter,] \& Leonion, M. S.

Irish potato breeding. South Carolina Agric. Expt. Sta. Bull. 195, 28 p., 1918.

\section{Newton, W[illiam]}

Infectious chlorosis of roses. Canada Dept. Agric. Div. Bot. Rpt. Dom. Botanist for the year 1930, p. 23, 1931.

A record of the presence of this disease.

\section{Nishimura, Makato}

A carrier of the mosaic disease. Bull. Torrey Bot. Club 45: 219-231, 1918.

The results of a series of inoculations experiments demonstrating that Physalis alkekcengi is a symptomless carrier of a mosaic disease.

\section{Noble R[obert] J[ackson]}

Some observations on the woodiness or bullet disease of passion fruit. Journ. Proc. Roy. Soc. New South Wales 62:78-79, 1928. 
Spotted wilt in tomatoes. Agric. Gaz. New South Wales 39 (1) : 59-63, 1928.

Brief popular deseription of the comparatively new virus disease.

Woodiness of Passion fruit. Cause of the disease discovered. Agr. Gaz. N. S. Wales 39(9) : 681-683, 1928.

Account of this disease in New South Wales. Description and nature of the disease. The author states that it is due to the action of a virus and is of infectious character. Gives control measures.

Biologist-New South Wales Dept. Agric. Ann. Rpt. 1927-28: 16, 1929. (Rev. Appl. Mycol. 9(1) : 18, 1930.)

Australia: success in control of bunchy-top disease of banana in New South Wales. Internat. Bull. Plant Protect. 7(9): 195, 1933.

Brief notes on production, damages and control in regard to bunchy top of bananas in Australia.

\section{Nolla, J[osé] A[ntonio] B[ernabé]}

Las enfermedades del tabaco en Puerto Rico. (Tobaceo diseases in Puerto Rico.) Ins. Expt. Sta. Puerto Rico Bull. 39, p. 24 25, 1932.

Brief notes on tobaceo mosaic. The author states that the disease affects the quality more than the yield. Gives nature and cause, of the disease, symptoms and treatment.

\section{\& Roque, Arturo}

A variety of tobacco resistant to ordinary tobacco mosaic. Journ. Dept. Agric. Puerto Rico 17(4) : 301-303, 1933.

A preliminary report. The variety was introduced from Colombia, Valle del Cauca, in 1929, by the senior author.

Noordanus, G.

Mosaiekziekte der frambozen. (Mosaic disease of raspberry.) Floralia $47(30): 472-473,1926$.

A brief note given on the occurrence of mosaic on raspberries in Holland. Gives degree of susceptibility of different varieties.

\section{Norris, Roland V[ictor]}

Spike disease of sandalwood. Nature 126(3174):311, 1930.

A review of recent progress in the study of this disease. The susceptibility of the sandal tree may be influenced by the host in which it grows. 
276 THE JOURNAL OF AGRICULTURE OF THE UNIVERSITY OF P. R.

\section{North, D[avid] S[utherland]}

The control of sugar-cane diseases. Australian Sugar Journ. 14(12) : 687-693, 15(1) : 9-24, 73-83. (Int. Sugar Journ. 26 (310) : 522-528, 1924. Rev. Appl. Mycol. 2:578-581, 1923.) This is a popular paper containing some data on virus disease.

\section{Norton, J[ohn] B[itting] S[mith]}

Irish potato disease. Maryland Agric. Expt. Sta. Bull. 108: 6372, 1905.

Report of the State Pathologist for 1910. Maryland State Hort. Soc. 13: 138-154, 1910.

Loss from mosaic disease of tomato. Phytopathology (Abstract) $4(6): 398,1914$.

Peach yellows and peach rosette. California Comm. Hort. Mon. Bull. 6(7) : 282-286, 1918.

Mosaic diseases and their control. Maryland Agric. Soc. \& Maryland Farm Br. 8:374-378, 1924.

\section{\& Heuberger, J. W.}

Factors influencing type and sequence of tomato mosaic leaf abnormalities. Phytopathology (Abstract) 23(1):26, 1933.

Novinenko, A. I.

(Insects as carriers of mosaic disease of sugar beet. Preliminary note.) Prot. Plants Ukraine 3-4:164-168, 1928.

(Insect vectors of sugar-beet mosaic.) Cent. Zuckerindus. 38: 400-401, 1930. (Facts About Sugar 25(19): 467, 1930.)

Insects as carriers of mosaic disease of sugar beet. Pub. Plant Breed. Dept. Sugar Union. Kiev. 3: III, 1930. (Stanz. Ent. Otd. 13, 15 p., 1930.)

(The insects as transmitters of mosaic disease of the sugar beet.) In V. P. Muraviov, Mozaichnye Bolezni Sakharnoi Svekly (Mosaic diseases of sugar beet.) Kiev, S.S.U. Souzsakhara p. 99-111, 1930. (English Abstract p. 111.)

Transmission experiments showed that the Aphis fabae gave a high percentage of infection as earrier of the disease. The bug Poeciloscytus cognatus proved to be less active. As the transmission 
does not occur at a distance greater than $700 \mathrm{~m}$. the author recommends the planting of sugar beet isolated at that distance from infested fields and susceptible weeds and to keep the plantation free of insects capable of transmiting sugar-beet mosaic.

\section{Nowell, W[illiam]}

Sugar-cane diseases in Puerto Rico. Agric. News (Barbados) $16(393): 158,1917$.

A comment to the Fifth Annual Report (1916) of the Insular Experiment Station of Puerto Rico, written by John A. Stevenson.

Mosaic disease of sugar cane. Agric. News (Barbados).19(462): 14, 1920.

A review of the United States Department of Agriculture Bulletin No. 829 by Brandes and Bulletin No. 19 of the Insular Experiment Station of Puerto Rico by F. S. Earle.

Eradication of mosaic disease in Trinidad. Trinidad and T(t)bago Dept. Agric. Bull. 19:105-106, 1921.

Diseases of crop plants in the Lesser Antilles, p. 325, 1923. This book contains much data on virus diseases.

\section{Oberstein, [Otto]}

Die Kräuselkrankheit der Zukerrübe in America und die neueren Theorien der Blattrollkrankheit der Kartoffel. (The curlyleaf disease of sugar beet in America and the new theories of the leaf-roll disease of potatoes.) Nachrichtenbl. Deutsch. Pfl. Schutzd. 3: 35, 1923.

\section{Ocfemia, G[eraldo] O[ffimaria]}

Progress report on bunchy-top of abacá or Manila hemp. Phytopathology 16(11) : 894, 1926.

This disease is caused by a virus and is carried by an Aphid, Pentalonia nigronervosa.

Second progress report on bunchy-top of abacá or Manila hemp. Phytopathology 17(4) : 255-257, 1927.

The heart rot of this plant is sometimes the last stage of bunchytop. Bunchy-top, due to other causes, is different from bunchy-top caused by the virus.

Bunchy-top of abacá or Manila hemp I. A study of the cause of this disease and its methods of transmission. Amer. Journ. Bot. 17(1) : 1-18, 1930.

This paper is a very thorough discussion of the symptoms, effects and transmission of this disease. 
Save the abacá industry from ruin by bunchy-top: The Philippine Agric. 20(3) : 167-169, 1931.

The author gives a warning to the country about the danger of the disease, also gives advise as to the means of overcoming the destructive disease in the producing provinces. States that the disease is of the virus type and transmitted by insects and is dangerous to abacá as well as to bananas.

The bunchy-top of abacá and its control. Phil. Agric. 20(5): 328-340, 1931.

A continuation of the author's work for the control of bunchy-top of Musa textiles.

Notes on some economic-plant diseases, new in the Philippme Islands. Philippine Agric. 19(9) : 581-589, 1931.

A disease of corn which resembles Fiji diseases of sugar eane is deseribed.

(A note) Philippine Agric. 21(5):358, 1932. (Sugar News $13(7): 751,1932$.)

In this brief note it is announced that Dr. Ocfemia of the Philippine College of Agriculture found the transmissibility of the Fiji disease of sugar cane by adults of the leafhopper Perkinsiella vastatrix Breddin. (Later in Amer. Journ. Bot. 21(3): 113, 1934, (4th foot note) the author claims that this is the first mention in print of the subject.)

An interesting reaction of a sugar-cane variety to grass mosaic. Philippine Agric. 21(6) : 414-419, 1932.

\section{Hurtado, Evaristo A., \& Hernández, Crispiniano C.}

Distribution of mosaic and Fiji disease in sugar-cane stalks; effects of these maladies on the germination of the eyes and transmission of the viruses by pin pricks. Philip. Agric. 22 (6) : 385-407, 1933.

The authors state that mosaie and Fiji diseases are two of the major diseases of sugar cane in the Philippines causing enormous losses to the sugar industry. They deseribe both diseases. Mosaic is transmitted by Aphis maidis Fiteh. Fiji disease by Perkinsiella vastatrix Breddin in the Philippines, while in Australia it is transmitted by $P$. saccharicida Kirk. They give extensive data of experiments in artificial transmission and germination.

An insect vector of the Fiji disease of sugar cane. Amer. Journ. Bot. 21(3) : 113-120, 1934.

The author reports the results of his experiments under earefully 
controlled conditions. He found that the adults of the leafhopper Perkinsiella vastatrix Breddin transmitted Fiji disease of sugar cane. The incubation period varied from 8 to 28 days. He describes the symptoms of the disease resulting from the transmission by the leafhopper under observation.

\section{Oehmichen, C., \& Hallier, E.}

Die Kräuselkrankheit der Kartoffel: I Form und Verbreitung der Krankheit. II. Ursache der Krankheit. (The eurl disease of potatoes. I Form and spreading of the disease. II Cause of the disease.) Landw. Presse 2:464, 1875.

Beobachtungen über des Auftreten der Kräuselkrankheit der Kartoffeln 1873-1875. (Observations on the behavior of the curl disease of the potatoes 1873-1875.) Zeitschr. Parasitenk $4: 144-152,1875$.

\section{Ogilvie, $\mathbf{L}\left[a_{\text {awrence }}\right]$}

Notes on leaf-roll of potatoes. Agric. Bull. Bermuda Dept. Agric. 3(12) : 1, 1924-25, 1925.

The raising of hyacinths in Holland. Journ. Ministry of Agric. $33: 248,1926$.

An important virus disease of Lilium longiflorum and its varieties. Nature (London) 119(2997): 528, 1927.

Aster yellows in Bermuda. A disease of many cultivated plants. Bermuda Agric. Bull. 6(5) : 7-8, 1927.

Virus diseases of plants in Bermuda. Bermuda Agric. Bull. 7 : 4-7, 1928.

A transmissible virus disease of the eastern lily. Ann. Appl. Biol. 15(4) : 540-562, 1928.

The author gives a review of the history of the disease. The disease is carried by Aphis gossyppi. It attacks $L$. formosum and $L$. giganteum.

Report of the plant pathologist for the year 1927. Bermuda Dept. Agric. Ann. Rpt. 1927:26-37, 1928.

Notes on mosaic disease of barana, Hippeastrum and lettuce. 


\section{\& Guterman, Carl E[dward] F[rederick]}

A mosaic disease of eastern lily. Phytopathology 19(3) : 311316, 1929.

There are three types of symptoms of this disease. The symptoms are partly masked by temperature above $70^{\circ} \mathrm{F}$. All attempts to transmit by insect or mechanical devices have failed.

Ring spot or spotted wilt of tomatoes and ornamental plants. Agric. \& Hort. Res. Stat. Long Ashton, Ann. Rpt. 1932:121122, 1933.

Brief notes reporting the occurrence of ringspot or spotted wilt discase on tomatoes, Streptosolen jamesonii, Schizanthus sp., Browallia speciosa major, Trachelium sp., begonias, Campanula pyramidalis and dahlias.

\section{Oldaker, G. E. W., \& Dowson, W[alter] J[ohn]}

Potatoes. Virus diseases and clean seed. Tasmanian Journal Agric. 1(1) : 14-18, 1929. (Rev. Appl. Mycol. 9:332, 1930.)

Includes descriptions and recommendations of control by growing seed at high altitudes. \&

Potatoes. Elimination of virus and other diseases. Care of "seed" from the selected plants. Tasmania Journ. Agric. n. s. 1: 87-91, 1930.

Potatoes, virus diseases and seed selection. Tasmanian Journ. Agric. n.s. 2(2) : 91-92, 1931.

\section{Olitsky, Peter K[osciusko]}

Experiments on the cultivation of the active agent of mosaic disease of tobacco and tomato. Science n. s. 60(1565): 593-594, 1924. (Journ. Expt. Med. 41(1): 129-136, 1925.)

The author gives an account of work from which he concludes that he has been successful in growing the organism in culture.

\& Northrop, J. H.

The inoculation of tomato and tobaceo plants with potato mosaic virus. Science n.s. 61(1586): 544-545, 1925.

The authors record the transmission of potato mosaic to tobacco and tomato.

The transfer of tobacco and tomato mosaic disease by the Pseudococcus citri. Science n.s. 62(1611): 442, 1925.

A brief paper giving evidences that this insect transmits the disease. 


\section{\& Hoffman, D[onald] C.}

The electric charge of mosaic virus particles. Proc. Soc. Exper. Biol. \& Med. 27(5) : 378-379, 1930.

\section{\& Forsbeck, F[ilip] G.}

Concerning an increase in the potency of mosaic in vitro. Science n. s. 74(1924) : 483-484, 1931.

The authors conclude that-"in view of the outcome of the experiments, we have concluded that the results of our tests cannot with certainty be referred to a true multiplication of mosaic virus." \&

The inactivation of mosaic-disease virus by pulverizing infected tissue. Science n. s. 75(1950) : 518-519, 1932.

The authors describe methods and give results of studies by which they conclude that "tomato-mosaic virus loses its infectivity when tissues containing it are comminuted by the methods described."

\section{Oliver y Lugo, Fernando}

El mosaico del tabaco y cómo combatirlo. (Tobaceo mosaic and how to control it.) Rev. Agric. Puerto Rico 10(1) : 11-14, 1923.

The author believes that the disease persists in the soil and recommends a three-year crop rotation.

\section{Oortwijn, Botjes, J. G.}

Iets over het kweeken van Ziektevoy pootgoed by aardappelen. Bull. of Direcie van den Landbouw te s-Gravenhage, 1919.

Raising phloem-necrosis and mosaic free potatoes, and a source of infection whose nature has not yet been elucidated. Phytopathology 10(1) : 48-49, 1920.

Gives recommendations for planting to obtain disease-free seed.

Die Blattrollkrankheit der Kartoffelpflanze. (Potato leaf-roll.) Inang. Diss: Landw. Hochsch. Wageningen, 1920, p. 16, 1920. A very thorough discussion of symptoms.

De bladrolziekte van der Aardappelplant. (Potato leaf-roll discase.) 8, 136 p., Wageningen, 1920.

Het gebruik van ourijpe aadappelknollen als pootgoed. (The use of unripe potato tuber for seed.) Culture 34:173-185, 1922. $35: 279-288,1923$.

Tubers that are harvested early will produce fewer diseased plants than tubers that are harvested late. This is because of a greater number of insect vectors in the late than in the early season. 
The potato selection farm at Oostwold, Rpt. Int. Conf. Phytopath. \& Econ. Ent. Holland p. 142-147, 1923. H. Veenman \& Sons, Wageningen.

The methods and results of seed selection.

Onbekende fetoren bij het kweeken van Ziektevrij pootgoed. (Unknown vectors in the propagation of disease-free seed.) Tijdschr. over Plantenziekten 29(7): 113-126, 1923.

Het vroeg rooien van voor pootgoed bestemde aardappelen. (Early digging of seed potatoes.) Tijdschr. Plantenz 29:132$133,1923$.

Die Verwendung unreifer kartoffeln als Saatgut. (Blattroll und Mosaikkrankheit.) Deutsche Landw. Presse 51:104, 1924.

Het optreden van bladol-en mosaiekziekten in den nabouw van gezonde Aardappelplanten, die op grooten afstand groeien van zieke plants. (The occurrence of leaf-roll and mosaic disease in the progeny of healthy potato plans grown at great distance from infested plants.) Tijsdschr. Plantenz 31(1): $1-6,1925$.

The disease was transmitted from diseased to healthy plants over 1,200 meters.

Iets omtrent de beteekenis van enkele aardappelziekten en vooral van het licht mosaick bij verschillende rassen. Landbouwkundg. Tijdschr. 40(483) : 687-692, 1928.

Kartoffelkrankheiten und abbau. Mitt. der D. L. G. 44:870$872,1929$.

\section{\& Quanjer, $\mathrm{H}$ [endrik] $\mathbf{M}[$ arius]}

Top-necrosis in the potato. Phytopathology (Abstract) 20(1): 138-139, 1930.

Empfänglichkeit von Kartoffellsorten gegen Viruskrankheiten. (Susceptibility of potato varieties to virus diseases.) Landbonwkundige Tiddschr. 509(42):517-529, 1930. (Fortschr. der Landw. 6(5): 173, 1931.)

The author failed to reveal complete immunity in any variety of potato. Different varieties contracted different virus diseases. 
Verzwakking van het virus der topnecrose, en verworven im. muniteit van Aardappelrassen ten opzichte van dit virus. (Attenuation of the virus of top necrosis and acquired immunity of potato varieties in respect of this virus.) Tijdschr. over Plantenziekten 39(10): 249-262, 1933.

Report of results obtained by grafting tuber cores on apparently healthy potato varieties.

Orian, G.

Les maladies de la canne á Maurice. (Sugar-cane disease in Mauritius.) Rev. Agric. de L'Tle Maurice 1929:206-210, 1929. (Rev. Appl. Mycol. 9:340, 1930.)

This paper contains a brief reference to the streak disease.

\section{Orton, C[layton] R[oberts], \& IMc Kinney Jr., W[illiam] $\mathbf{H}$.}

Winter blight of the tomato. Pennsylvania Agric. Expt. Sta. Ann. Rpt. 1915 : 235-246, 1915.

A report of studies on the disease; at that time the disease was not known to be due to a virus.

\section{Orton, W[illiam] A[llen]}

Environmental influence in the pathology of Solanum tuberosum. Journ. Wash. Acad. Science. 3: 180-190, 1913.

A brief discussion of some of the virus diseases of potatoes.

Potato leaf-roll. U. S. D. A. Br. Plant. Indus. Circ. 109:7-10, 1913.

Description and control measures.

Leaf-roll, curly-leaf and other potato diseases. Phytopathology (Abstract) 3(1):69, 1913.

Potato wilt, leaf-roll and related diseases. U. S. D. A. Bull. 64: 48 p., 1914.

History, description, character, geographical distribution, theories as to cause, methods of control. Also a brief discussion of curlydwarf.

Inspection and certification of potato seed stock. Phytopathology (Abstract) 4(1):39-40. 1914.

\section{\& Rand, Frederick V[ernon]}

Pecan rosette. Journ. Agric. Res. 3:149-174, 1914.

History, distribution, symptoms and experiments. Believe it to be a non-infectious chlorotic disease. 
284 THE JOURNAL OF AGRICULTURE OF THE UNIVERSITY OF P. R.

Streak disease of potato. Phytopathology $10(2)$ : 97-100, 1920. The author gives a description of the disease and discussion of varietal resistance.

New work in potatoes diseases in America. Roy. Hort. Soc. Int. Potato Conf. Rpt. 1921: 169-179, 1921.

An early report on infectious chlorosis. Phytopathology 14: 189-199, 1924.

The writer quotes an early record of 1715 .

Osborn, H. T.

Incubation period of pea mosaic in Macrosiphum pisi. Phytopathology (Abstract) 24(1) : 15, 1934.

\section{Osterspey,}

Kin Versuch über Einfluss der Düngung auf der Blattrollkrankheit und den Ertag der Kartoffeln. (An experiment on the influence of manure on the leaf roll disease and on the yield of potatoes.) Mitt. D. Landw. Ges. 26:222-224, 1911.

\section{Otero Braquertt, J[osé]}

Unas palabras sobre la enfermedad de la caña "El matizado" o "Rayas amarillas". (A few words about the sugar-cane disease mottling or "yellow stripe".) Rev. Agric. Com. \& Trabajo, Cuba, $7(4)$ : 46-54, 1924.

Sobre la enfermedad de la caña "El mosaico" o "Rayas amarillas". (About "mosaic" or "yellowstripe", disease of sugar cane.) Rev. Agric. Com. y Trab. Cuba, 7(4) : 54-56, 1924.

Page, R. L.

The future of Uba cane in Puerto Rico. Memoirs Ass'n SugarCane Tech., Puerto Rico. 1(1):25-27, 1922. (Facts About Sugar.) 15:420-421, 1922.

A brief reference to varietal resistance and susceptibility.

La enfermedad del matizado; su extirpación y control. (The mottling disease; its eradication and control.) Rev. Agric. Puerto Rico. 11(1) : 19-22, 1923. (Australian Sugar Journ.) 15(7) : 428-429, 1923. Facts About Sugar 17(1) : 14-15, 1923.)

Fields have been practically freed from mosaic by roguing. 


\section{Pagliano, T[héophile] C[arles] L[ouis ]}

Quelques maladies de cotonnier. (Some diseases of cotton.) Rev. Hort. Tunisie 23:225-227, 1925.

\section{\& Bewley, W. F.}

Stripe disease of tomatoes. Journ. Min. Agric. 26(10) : 9981000, 1920.

\section{Palm, B[jön] T[orvald]}

De mosaickziekte van de tabak een Chlamydozoonose? (Is the mosaic disease of tobacco a Chlamydozoonose?) Medan Sumatra. Deli Proefstat. Bull. 15: 7-20, 1922.

A study which leads to the describing of what the author believes to be a chlamydozoon under the name of Strongyloplasma Iwanowskii.

Bestrijding van plagen en ziekten in the tabakscultuur. Verslag van een sturdiereis in Europe en de Vereenigde Staten. (Combating pests and diseases in tobacco. Report of a study trip in Europe and United States.) Medan Sumatra. Deli Proefstat. Ann. Rpt. 1922-23: 53-54, 1923.

\section{Pantanelli, En[rico]}

Sui caratteri dell'arriciamente e del mosaico della vite. Sepans. Malpighia, an XXV. 56. Catania 1912.

Sulla causa del mosaico della piante. (The cause of mosaic disease of plants.) Boll. Meno. R. Staz. Patl. Veg. (Rome) 1(3-4) : 41-41, 1920.

The author reports that the mosaic of Hypochaeris radicata is caused by Macrosiphora tussilaginis.

\section{Pape, H[einrich]}

Das verheerende Auftreten der Krauselkrankheiten bei Pelargonien. Die Gartenwelt 31(22) : 329-331, 1927.

Eine neue Krankreit des poinsettie. (A new disease of pomsettia.) Gartenwelt 31: 772-773, 1927.

Mosaikkrankheit bei Rhododendron. Gartenwelt 35(45):621, 1931.

Zur Kräuselkrankheit der Poinsettie. (The curl disease of Poinsettia.) Gartenwelt 35(52): 716, 1931. 
Mosaikkrankheit an Glieder-, Blatt-und Rutenkakteen. (Mosaic disease of joint-leaf-and twig Cactaceae.) Gartenwelt 36: 707708, 731-732, 1932. (Zentralb. für Bakt (Abstract) Ab. 2, 88(13-16) : 349, 1933.)

Description of a mosaic disease of cactus oceurring in Germany. Gives methods of control and the following list of species affected: Epiphyllum truncatum (Deutsche Kaiserin), E. harrisonii, E. hybridum rubrum, Meteor, President Grevy, E. rosa amabilis, E. salmoneum, Vesuvius, E. violaceum superbum, E. bridgesii, Phyllocactus gaertneri var mackoyanus and Rhipsalis rosea.

\section{Paravicini, Eugen}

Die Kartoffelkrankheiten in Niederlanddisch "Ost" Indian. (Potato diseases in the Dutch East Indies.) Cent. fur Bakt. 58: 212-220, 1923.

\section{Parisot}

Recherches sur la filosité de la Pomme de terre. (Researches about the "filosité" of the potato.) Ann. Ecole Not. Agr. Rennes 4, 1910.

\section{Park, M[alcolm ]}

Report of the Mycological Division. Ceylon Dept. Agric. Tech. Rpts. 1928:1-6, 1929. (Rev. Appl. Mycol. 9(2) : 88, 1930.)

This paper contains a record of mosaic on eggplant and okra.

Matters of phytopathological interest during 1929. Trop. Agric. (Ceylon) 74(4): 195-199, 1930.

Banana bunchy top is reported.

Some diseases of plantains in Ceylon. Trop. Agric. Ceylon, 75 (6) : 347-353, 1930.

The etiology of bunchy top disease is given. It has been known in Ceylon since 1913. Today it is widespread.

The oil treatment of plantain diseases. Trop. Agric. (Ceylon) 81(2) : 86-90, 1933.

Report of treatment of gas oil 0.864 specific gravity for bunchy top in banana.

\section{Parker, E. R., \& Horne, Wm. F.}

The transmission of avocado sun-blotch. California Avocado Assoc. Yearbook 1932: 50-56, 1932.

This paper gives the results of grafting and budding experiments which demonstrate that the disease is carried in stock and in scions. 


\section{Pascalet, IMI.}

La mosaïque ou lepre du Manioc. (The mosaic or leprosy of manioc.) Agron. Colon. 21(172) : 117-131, 1932.

\section{Passy, P.}

Une nouvelle maladie du poirier. (A new disease of the pear tree.) Rev. Hort. 35: 252-253, 1913. (Intern. Agrar. Techn. Hundschan 4:1152, 1913.)

It refers to pear msoaic.

\section{Patch, Edith $\mathbb{M}[$ [arion]}

Rose bushes in relation to potato culture. Maine Agric. Expt. Sta. Bull. 303: 321-344, 1921.

Gives evidence that Macrosiphum solanifolii overwinters in rose bushes.

The buckthorn aphid. Maine Agric. Expt. Sta. Bull. 317:29$52,1924$.

Aphis abreviata passes the winter on Rhamnus. A list of its food plants is given.

\section{Peacock, W[alter] MIiller]}

The elimination of virus diseases. Ann. Pat. Journ. 4:127-129, 1927.

\section{Peltier, Geo[rge] L(eo)}

The "false blossom" of the cranberry. Unpub. Thesis Wisconsin Univ. Library, 24 p., 1910.

Experiments on stem rot at Illinois University. Amer. Florist 40 (1292) : 324-327, 1913. (Flor. Ex. 35(11) : 575-577, 1913. Flor. Rev. 3 : (797) : 24-26, 1913.)

Diseases of carnation. Flor. Ex. 37(5):252-553, (6) : 320, (7) : 372-373, 1914.

Report of the Illinois Pathologist. Amer. Flor. 41(1346), 432434, 1914.

Work at Illinois Florist Experiment Station.-Carnation Diseases. Flor. Rev. 33(851): 22, 52, 56, 1914.

Carnation disease: In J. H. Dick Commercial carnation culture, New York, p. 237-252, 1915.

A brief account on carnation yellows before the cause of the disease was known. 
288 THE JOURNAL OF AGRICULTURE OF THE UNIVERSITY OF P. $\mathbf{R}$.

Mlinois Pathologist report. Amer. Flor. 44(1398): 439-440, 1915.

Stem rot of carnation. Flor. Ex. 39(10):539, 1915.

'Carnation diseases. Flor. Rev. 35(901): 14, 1915. (Horticulture $21: 373,1915$.)

Pathologist report. Flor. Ex. 41(11): 608, 1916.

Carnation diseases. Flor. Rev. 37(954): 20, 1916.

Carnation yellows. Amer. Flor. 46(1443) : 60-61, $1916 . \quad$ (Flor. Rev. 37(948) : 23-24, 1916.)

Report of observations made by the author; he recognizes that there are several forms of the disease, which he describes briefly. It was transmitted by grafting but not by the seed.

Control of carnation yellows. Amer. Flor. 46(1455) : 725-726. 1916.

Popular.

Carnation yellows. Proc. Amer. Carn. Soe. 25:29-35, 1916.

\section{\& Goss, $R$ [obert] W[hitmore]}

Control equipment for the study of the relation of environment to diseases. Nebraska Agric. Expt. Sta. Res. Bull. 28, 16 p. 1924.

Pemberton, C. E.

Entomology. Report Comm. Expt. Sta. H.S.P.A. 1923-24: 13. $32,1924$.

Reports that Aphis maidis produces severe symptoms of mosaic on Syntherisma sp.

\section{Penhallow, D[avid] P[earce]}

Peach yellows. Houghton Farm. Expt. Sta. ser. III 2: 25-45, 1882.

Gives the results of chemical and microseopical studies of the peach wood, ete. Also discusses external characters, soil and atmospheric influences.

\section{Perreau.}

Note sur la Nielle des tabacs. (Notes on the mosaic disease of tobaceo.) Bull. Soc. Bot. France 56(1) : 53-54, 1910. 


\section{Perret, C[laude]}

Les formes de dégénérescence de la Pomme de terre. (Forms of degeneration of the potato.) Notes \& Act. R. Sci. No. 632, Oct. 23, 1920.

Sur les maladies des pommes de terre. (About diseases of the potato.) Ann. Epiphyties 7:304-314, 1921.

This paper gives the results of experimental work with fertilizers and at various altitudes.

(The contest against degeneration.) Vie Agric. \& Rurale 19: 180-185, 1921.

La dégénérescence de la Pomme de terre. (Degeneration of the potato.) Bull. Soc. Path. 9(1) : 39-42, 1922.

(Potato leaf roll (Loire). Assoc. France Avanc. Sci. Conf. Compt. Rend. 46: 884-889, 1922.

Fletrissement des pieds et filosité de la pomme de terre. (Fout: wilt and "filosité" of the potato.) Rev. Path. Vég. \& Ent. Agric. 10: 168-171, 1923.

Recherches sur la dégénérescence de la pomme de terre. (Research on potato degeneration.) Ann. Epiphyt. 9:61-69, 1923.

La dég'énérescence des pomme de terre. (The degeneration of the potato.) La Vie Agric. 23(30):61-66, 1923.

Les maladies de la pomme de terre en 1924. (Potato diseases in 1924.) Rev. Vég. et Ent. Agric., 11(4) : 309-316, 1924.

Apropos de la filosité de la pomme de terre. ("Filosité" of the Potato.) (Rev. Path. Vég. Ent. Agric. 13(24) : 319-322, 1926.

La station de sélection des Pommes de terre de la Loire. (The potato selection station of the Loire.) Bull. Off. Agric. Massiff. Central 10: 83-93, 1929.

\section{Pestana, Antonio Carlos}

La caña Uba y la enfermedad del mosaico. (Uba cane and the mosaic disease.) El Mundo Azucarero 12(11) : 328-329, 1925. 
290 THE JOURNAL, OF AGRICULTURE OF THE UNIVERSITY OF P. $\mathrm{R}$.

(Translated from Journal de Lavoura, Brazil.) (Louisiana Planter $74(15): 291,1925$.)

\section{Peters, L[eo]}

Krankheiten und Beschädigungen des Tabaks. (Diseases and injuries of tobacco.) Mitteil. Kais. Biol. Aust. Land. Fortstraw. 13 : 58-64, 1912 .

Describes disease, discusses work of others and gives recommendations for control.

Krankheiten des Tabaks. (Tobacco diseases.) Ber. über die Tätigkeit der Biol. Reichsanst. 1919: 62, 1920.

\section{Peterson, $\mathbf{P}$ [aul] $\mathbf{D}$ [onald]}

Plastids pigment and chlorophyllase contents of tobacco plants as influenced by three types of mosaic. Phytopathology (Abstract) $21(1): 119,1931$.

\section{Pethybridge, G[eorge] H[erbert]}

Potato diseases in Ireland. Ireland Dept. Agric. \& Tech. Instruction Journ. 10(2) : 241-256, 1910.

Leaf roll and "curl". Ireland Dept. Agric. \& Tech. Instruction Journ. 11(3) : 447-499, 1911.

"Curl and "leaf roll". Ireland Dept. Agric. \& Tech. Instruction Journ. 12(2) : 354-356, 1912.

Investigations on potato diseases (Fourth Report). Ireland Dept. Agric. \& Tech. Instruction Journ. 13(3) : 445-468, 1913.

Investigations on potato diseases IX-X. Ireland Dept. Agric. \& Tech. Instruction Journ. 18(4) : 410-416, 1918. 19(3) : 271$272,1919$.

A discussion of the 1918 Ireland crop with special reference to some diseases including leaf roll. It was treated by heating the tuber as a means of prevention. It is claimed that heat did not produce leaf roll.

Potato leaf-roll. Journ. Min. Agric. 31(9) : 863-869, 1924.

A suspected virus disease of zonal Pelargoniums. Gard. Chro. $92(2395)$ : 378-379, 1932. 


\section{Petri, L[ionello]}

Recerche sulle cause dei deperimenti delle vite in Sicilia. IContributo allo studio dell'azione degli abbassamenti di temperatura sulle vite in repporto all' arricciamento. (Researches on the cause of the decline of the vine in Sicily. I-Contribution to the study of the vine in relation to the curling.) Mém. R. Statioze Patologia Veg., Roma 212 p., 1912.

Nuave vedute sulle cause dell' arricciamento della vite. (New views about the cause of the curling of the vine.) $R$. Acad. Linei 27:271-275, 1918.

L' arricciamento della vite é una malattia prodotta da protozoi? (Is leaf roll of the vine a disease produced by protozoa? Rendic. Acad. Lincei ser. 8, 32(5) : 395-397, 1923.

Stato attuale di alcuni problemi di fitopatologia. (Present statuis of certain problems of phytopathology.) Conferenza tenuta in Roma al XVIII Congresso delle Caltedre Ambulanti di Agricoltura Italiane il 10 Maggio 1924, 16 p., 1924.

Sulle cause dell' arricciamento della vite. (On the cause of leaf roll of the vine.) Boll. R. Staz. Pat. Veg. n. s. 9(2) : 101-130, 1929 (Rev. Appl. Mycol. 9(2) : 83-85, 1930.)

The author gives proof that "arricciamento", (Coutnone, roncet, Krantem and Reisigkrankheit) of the grape vines is caused by a virus.

Sur une méthode pour effectuer les injections de virus dans les feuilles. (About a method to practice virus injection into the leaves.) Second Intern., Cong. Compt. Path. Paris Compt. Rend. Communications 2 : 439-441, 1931.

Method and device is described for injecting mosaic virus into citrus leaves.

Sull "arricciamento" della vite. (The curling of the vine.)

Boll. R. Staz. Patol. Veget., (Rome) n. s. 11(1) : 61-83, 1931.

Bodies analogous to $x$-bodies were seen near the nuclei in root-tip cells. The disease is infectious and is believed to be virus. The filterable virus phase diffuse and produce the degeneration stage in the root tip. 
Maculatura interna ereditaria dei tuberi di patata. (Hereditary internal spotting of potato tubers.) Boll. R. Staz. Patol. Veg. $11(2): 171-175,1931$.

An internal necrosis which is transmitted by the tuber.

Variegatura infecttiva delle foglie di "Citrus vulgaris". (Infectious variegation of the leaves of "Citrus vulgaris".) Risso Bull. R. Staz. Pat. Veg. 11(2) : 105-114, 1931.

\section{Phillips, J[ohn] L[loyd]}

Yellows and some other important diseases of the peach. Virginia State Crop \& Pest Comm. Circ. n.s. No. 4. 1908.

A popular discussion of peach yellows, peach rosette and little peach.

Peach yellows as it affects nurserymen. Address before American Nurserymen's Association. Milwankee Wis., June 12, 1908.

A popular discussion giving some losses.

\section{Pieper, [Walter]}

Die ursuchen und wirkungen des Kartoffelabbauer. (The causes and effects of potato degeneration.) Illus. Landw. Zeit. 50 (1) :134-135, 1930. (Rev. Appl. Mycol. 9:602, 1930.)

This paper discusses the influence of environment on mosaic and leaf-roll.

\section{Pierce, W[alter] H[oward], \& Hugenford, C[harles] W[illiam]}

Symptomatology transmission, infection and control of bean mosaic in Idaho. Idaho Agric. Expt. Sta. Res. Bull. 7, 37 p. 1929 .

The authors give a discussion of the symptoms, the losses and inoculation experiments. Resistant varieties offer the best method of control.

A note on the longevity of the bean mosaic virus. Phytopathol ogy 19(6) : 605-606, 1929.

The disease was carried in seed 32 years old.

Viruses of the bean. Phytopathology 24(2) : 87-115, 1934.

Thorough study on variety resistance of bean (Phaseolus vulgaris) to virus of common-bean mosaic. The author classifies the viruses and gives the susceptibility of each variety in tabulated form. Gives also data on insect vectors. 


\section{Pinazzoli, F[rancesca]}

Male della bolla e del mosaico. Boll. Teen. della coltivazione dei tab. R. Inst. Sperim. Scafati (Salermo) 3(4) : 1-14, 1904.

\section{Pinkhof, Marianne}

Untersuchungen über die umfallkrankheit der tulpen. (Investigations on the falling disease of tulips.) Recueil Trav. Bot. Néerlandais 26:135-288, 1929. (Rev. Appl. Mycol. 9:528, 1929.)

\section{Pitt, W.}

On discovering the cause and pointing out the cure for the curl in potatoes. Trans. Soc. Encouragement of Arts, Manuf. \& Comm. 8:31-34, 1790.

Historical value only.

Discussing eurl or degeneration of potatoes. Trans. Soc. Encouragement of Arts, Manuf. \& Comm. 8: 1790.

Historical value only.

\section{Pittman, H[arold] A[mbrose Jacques]}

Spotted wilt of tomatoes. Journ. Council Sci. \& Indus. Res. (Australia) 1(2) : 74-77, 1927.

The disease is carried by Thrips tabaci but the insect may disappear before the development of the symptoms.

\section{Plakidas A[ntonios] G[eorge]}

An obscure new disease of the strawberry in California. Phytopathology (Abstract) 15(11):730, 1925.

Strawberry yellows, a degeneration disease of the strawberry. Phytopathology 16(6) : 423-426, 1926.

A preliminary report giving description and stating that the disease is transmitted by the aphis (Aphis fragaefolii) and possibly by the red spider (Testranychus telarius).

Strawberry xanthosis (Yellows), a new insect-borne disance. Journ. Agric. Res. 35(12) : 1057-1090, 1927.

The author gives a description of the disease and proof that it is transmitted by Myzus fragaefolii. He also reports the finding of bodies which he designates as $\mathrm{X}$ and $\mathrm{Y}$.

Strawberry dwarf. Phytopathology 18(5) : 439-444, 1928.

$A$ pre!mina:y roport. The evidence indicates that the disease is due to a virus which is carried by Aphis forbesi. 
294 THE JOURNAL OF AGRICULTURE OF THE UNIVERSITY OF P. R.

Report on strawberry virus disease project. U.S.D.A. Plant Disease Reporter 13(9):129-131, 1929. (Rev. Appl. Mycol. 9(3) : 193, 1930.)

The "June yellows" of Strawberries. Phytopathology (Abstract) $22(1): 22,1932$.

Poeteren, $N$ [icolas $]$ van

Verslag over de workzaamheden vanden plagenziektenbudingen diest in het jaar 1923. (Annual Report of the Phytopathological Service for 1923.) Verslag, en Mededeel. Plantenziekten. Diest Wageningen 34:1-66, 1924.

Pompeu de Amaral, A.

Mrsaic. Bol. Agr. Sao Paulo (Brasil) 27(4-5) : 146-156, 1926.

\section{Poole $\mathbf{R}$ [obert] $\mathbf{F}$ [ranklin]}

Celery mosaic. Phytopathology 12(3) :151-154, 1922.

The first description of the disease. It is carried by Myzus persicae.

Celery mosaic. New Jersey Agric. Expt. Sta. Ann. Rpt. 1922: 567-568, 1922.

Tomato crop losses may be reduced. New Jersey Agric. (New Brunswick) 6:5, 1924.

Popular.

Porter, D. R.

New onion disease in Iowa. U.S.D.A. Plant Disease Reporter $12(8): 93-94,1928$.

Note on the occurrence of a new virus disease of onions in Iowa.

The infectious nature of potato calico. Hilgardia 6(9):277294, 1931.

The author reports a calico disease of potato in California which appears to be due to a virus.

\section{Porter, R[upert] H[oward]}

Further evidence of resistance to cucumber mosaic in the Chinese cucumber. Phytopathology (Abstract) 18(1):143, 1928.

Reaction of Chinese cueumber to mosaic. Phytopathology (Abstract) 19(1):85-86, 1929. 
A new mosaic disease of cucumber. Phytopathology (Abstract) 20(1) : 113, 1930.

The resistance of cucumber to mosaic. Phytopathology (Abstract) $20(1): 114,1930$.

The reaction of cucumber to types of mosaic. Iowa State Coll. Journ. Sci. 6(1) : 95-99, 1931.

This paper gives the results of hybridization studies, cross-inoculations and a description of a new type of mosaic.

Reaction of tomatoes to mosaic. Phytopathology (Abstract) 22 (1) : 22, 1932 .

\section{Price, W[illiam] C[onway]}

The thermal death rate of tobacco-mosaic virus. Phytopathology 23(10) : 749-769, 1933.

A well illustrated article with tables and time-temperature curves showing the thermal death rate of tobacco-mosaic virus.

Local lesions on bean leaves inoculated with tobacco mosaic virus. Amer. Journ. Bot. 17(7):694-702, 1930. (Boyce Thompson Inst. Contrib. 2(10):549-557, 1930.)

The author gives the results of experiments showing that when bean leaves were inoculated with tobacco mosaic by rubbing the upper surfaces, necrotic lesions were formed on some and not on others. More virus was recovered from those with lesions than from those without lesions.

Acquired immunity to ring-spot in Nicotiana. Boyce Thompson Inst. Cont. 4(3) : 359-403, 1932.

A thorough discussion of the subject, describing observations made by the author by experimentation. He emphasizes the environmental conditions influencing the disease. Gives the species of Nicotiana and varieties on which recovery was observed. No attenuation of the virus was obtained in cases of recovery; this conclusion was reached by actual experimental inoculations as well as the inoculation on recovered plants which showed no symptoms of reinfection. The disease persisted in plants propagated by cuttings through three generations, but was not transmitted through seed. No evidence was obtained from grafting experiments, that acquired immunity in tobaceo was accompanied by the production of anti-bodies. The symptoms of tobacco mosaic in plants which recover from ring-spot are different from those in plants which recover from ring-spot disease. Certain plants are observed to be killed by ring-spot. 


\section{Prince, W.}

A short treatise on horticulture, New York, p. 14-15, 1828.

This is the first exact description of peach yellows.

\section{Priode, C[arl] N[eal]}

Further studies in the ring-spot disease of tobacco. Amer. Journ. Bot. 15(1) : 88-93, 1928.

This is a continuation of previous studies. The author gives the results of inoculations and some data on the effects of temperature on the virus.

Cuban streak. Phytopathology 23(8):674-676, 1933.

Description of the symptoms of a new disease on POJ 2725 and CAC 323 sugar-eane varieties. The disease was named "Cuban streak" and tentatively attributed to a virus. The symptoms are different from those of sugar-cane South African streak. The insect vector of the South African streak Cicadula mbila is not known in Cuba.

\section{Pritchett, G. H.}

Eradication of Fiji disease at Calamba. Sugar Centr. \& Flante: News. 2(10) : 413-416, 1921.

Points from cane affected with mosaic disease versus points from healthy eane at Hacienda Soledad owned by Mr. José Yunsay. Sugar Cent. \& Planter's News 5(5) : 243-247, 1924. (Rev. Appl. Mycol. 3:609, 1924.)

A comparison of results obtained from the use of healthy and diseased points.

Insect pest and cane diseases. Louisiana Planter 73(24): 470473, 1924. (Second Ann. Conf. Philippine Sugar Ass'n. Oet. $1-7,1924$.)

Popular account of Fiji and mosaic disease.

Mosaic disease test of Hacienda Tres Corazones owned by Mr. Manuel González, Isabela, Occidental Negros. Sugar Cent. \& Planters' News 6(12) : 791-792. 1925. (Rev. Appl. Mycol. 5 (6) : 329-330, 1926.)

The principal cane disease and insect attacks affecting the several estates of Negros (Philippines). Sugar News 8(11):883892, 1927. (Rev. Appl. Mycol. 7:345, 1927.)

Popular discussion of Fiji and mosaic diseases. 


\section{Proida, P. A.}

(Mosaic of sugar beet) In V. P. Muraviov, Mozaichnye Bolezni Sakharnoi Svekly (Mosaic diseases of sugar beet.) Kiev S.S.U. Soiuzsakhara p. 11-66, 1930. (English abstract p. 64-66.)

Studies and field observations during 1925-1927. The disease is described. From year to year the disease may be transmitted through the roots, and insects act as carriers. No resistant varieties are known locally and sugar reduction due to the disease has not been estimated.

\section{Prunet, I[gnace] A[dolphe]}

La dégénérescence de la pomme de terre. (Degeneration of the potato.) Prog. Agri. et Vitie 73:9-15, 1922.

\section{Purdy, Helen A[lice]}

Attempt to cultivate an organism from tomato mosaic. Bot. Gaz. 81 (2) : 210-217. (Contr. Boyce Thompson Inst. Plant Res. 1: 146-154, 1926.)

The writer conducted experiments following the methods of Olitsky but failed to find any evidence that the organism multiplied outside the living plant.

Multiplication of the virus of tobaceo in detached leaves. Phytopathology (Abstract) 17(1):58, 1927. (Amer. Journ. Bot. 15(1) : 94-99, 1928.)

The author inoculated healthy leaves after removal from the plant and gives evidence that the virus increased in these leaves.

The improbability of tobacco mosaic transmission by slugs. Amer. Journ. Bot. 15(1) : 100-101, 1928.

A brief paper giving proof that slugs are not earriers.

Immuniology reactions with tobaceo mosaic virus. Proc. Soe. Expt. Biol. \& Med. 25:702-703, 1928. (Journ. Expt. Med. $49(6)$ : 919-935, 1929.)

This paper gives the results of experiments along the line of those in practice in the study of virus diseases of animals.

Specificity of the precipiting reaction in tobaceo mosaic disease. Contr. Boyce Thompson Inst. 3(4) : 529-540, 1931.

The viruses of tobacco ring spot and cucumber were used as antigens in precipiting tests with anti-serum for virus of tobacco mosaic.

\footnotetext{
* Appears as Helen Purdy Beale.
} 
Serologic reaction as a means of determining the concentration of tobacco mosaic virus. Phytopathology (Abstract) $23(1): 4$, 1933. (Rev. Appl. Mycol. 12:398, 1933.)

\section{Puttemans, A [rsene]}

O "mosaico" da canna de azucar. (The mosaic of sugar cane.) Boll. Min. Agric. Ind. o Com. Brazil 15(2) : 350-355, 1926. Rev. Appl. Ent. Ser. A. 15:67, 1926.)

\section{Putterill, V[ictor] A[rmsby]}

Tomato mosaic in South Africa. Plant diseases in the western Cape Provinces. IX. Journ. Dept. Agric. South Africa 7(2): 131-141, 1923.

\section{Quanjer, H[endrik] $\mathbf{M}$ [arius]}

Nekrose der kartoffelpflanze, di Ursache der Blattrollkrankheit. (Necrose of potato plant, the eause of leaf-roll disease.) Meded. R. Hoog. Land Tuin-en Boshbouwsch. Wageningen 6: 41-80, 1913.

\section{\& Oortwijn Botjes, J.}

(Review of experimentation in the Netherlands looking to the control of cereal and grass smuts and stripe disease.) Ztrehr. Pflanzenkrank, 15(8) : 450-460, 1915.

wijn, Botjes J.

Aard verspreidengswijze en bestrijding van phloeemnecrose (Bladroll) en verwante ziekten. (Nature of spreading and combating phloem-necrose (Leafroll) and allied diseases.) Meded. R. Hoog. Land Tuin en Boschbouwsch. Wageningen $10: 1-138,1916 . \quad$ (Gard. Chron. 3 Ser. (1550): 124, 1916.)

Recherches sur la leptonécroses de la pomme de terre et les maladies apparentés, factes de 1907 a 1917 . (Researches about the leptonécrose of potato and related diseases, oceurring from 1907 to 1917.) Ann. Soc. Agri. 34:301-357, 455-494, 1918.

\section{\& Oortwijn, Botjes J.}

L'enroulement des feuilles (Leptonécrose) et la frisolée (mosaïque) de la pomme de terre. (Leaf-roll and curly dwarf of potato.) Ann. Sci. Agron. Francaise et Etrangére 36:262$280,1919$. 
Phloem neerosis (leaf-roll). and mosaic (including curly dwarf) are similar. A very lengthy discussion including the results of experiments.

\section{$\mathbf{A}[\mathrm{me}] \mathrm{W}$ [ilhelm] van der}

De mozaiekte van de sonanceen hare verwantschap met de phloemnecrose en hare beteekenis voor de aardappelcultuur. (The mosaic disease of the Solanaceae: its relation to phloemnecrosis and its effect on potato culture.) Meded. van de Landbouw Hoogeschool deel, 17 : 1-74, 1919.

A lengthy discussion of leaf-roll and mosaic. The leaf-roll is the same as phloem-necrosis or lepto-necrosis.

Mosaic disease of the Solanaceae, its relation to the phloemnecrosis, and its effect upon potato culture. Phytopathology $10(1): 35-47,1920$.

Gives the results of experiments demonstrating the similarity of tobacco, tomato and potato mosaic.

Considérations nouvelles sur les maladies de la pomme de terre. (New considerations of potato diseases.) Bull. Soc. Path. Veg. $7: 102-118,1920$.

Guide pour 1' inspection aux champs et pour la sélection de pomme de terre. (Guides for field inspection and potato selection.) Imp. Veeman-Wageningen, Holland, 27 p., 1921.

\section{\& Foex, $\mathbf{E}[$ dmund] $\mathbf{E}[$ tienne]}

Mission d' études sur les maladies de la pomme de terre, en France. (Mission for the study of the potato disoases in France.) Ann. des Epiphyties, 7:267-280, 1921.

New work on leaf curl and allied diseases in Holland. Int. Potato Conference. Roy. Hort. Soc. London 1921: 127-145, 1921. This paper is devoted primarily to a discussion of symptoms and of insect transmission.

De degeneratieziekten van de aardappelplant. (Degeneration disease in potato plant.) Vakland voor Biologen 11:97-104, 117-121, 1921.

Een proef over de beteeknis van ziekten en ziekteverspreiding bij de pootgoedverwisseling, genomen door het Instituut voor Phytopathologie in 1920 en 1921.) (An experiment on the signif- 
icance of disease and disease distribution relative to changing of seed potatoes, conducted by the Institute for Phytopatkri. ogy in 1920-1921.) Cultura 34:135-141, 1922.

The greater the disease the greater the degeneration of potatoes. The greater the number of insects the greater the amount of disease.

General remarks on potato diseases of the curly type. Rept. Int. Conf. Phytopath. \& Econ. Ent. Holland, p. 23-28. II. Veenman \& Sons, Wageningen, 1923.

Krauselkrankheit and dwarf were used by earlier writers for diseases now known as leaf-roll, stripe, streak and different types of mosaic. The author discusses transmission and overwintering and describes a number of virus diseases of potatoes.

Un nouveau chapitre de la patyologie vegetale reliant cette science á la pathologie animale. (A new chapter in plant pathology connecting this science with animal pathology.) Rev. Path. Veg. et Ent. Agr. 10(50):22-40, 1923.

So-called "virus diseases" of plants; their symptoms, causation, mode of dissemination and economic importance from a physical point of view. Brit. Ass'n. Adv. Sci. Rpt. (Abstract) 91 : 492-493, 1923.

Standardizing of degeneration diseases of potatoes. Phytopathology 14(11) : 518-520, 1924.

The author discusses pure eulture methods and the confusion resulting from overlapping symptoms.

So-called "virus diseases" of plants; their symptoms, causation, mode of dissemination, and economic importance from a physiological point of view. British Assoc. Adv. Sci. Rpt. (Abstract) $1923: 492-493,1924$.

Kringeriheid bij aardappelen. (Curl disease of potatoes.) Woordr. uit. o. d. Plantenteeltdag 30 Juni en 1 Juli, Wageningen p. 50-54, 1926.

\section{\& Elze, D[avid] L[eon]}

Achterurtgang van pootgoed van gelijke afstamming in de verschillende vroege-aardappeldistricten. (The degeneration of seed of identical origin in the different early potato districts.) Tijdser. over Plantenziekten 31(1):11-14, 1925. 
Waarnemingen over "Kringerigheid" of "vuur" en over "netnecrose" van Aardappelen. (Observations on "sprain" and net-necrosis of potatoes.) Tijdschr. over Plantenziekten $\mathbf{7 2}$ (4) : 97-128, 1926. (English Summary.)

"Sprain" disease of potatoes is discussed at some length with reference to the work of contemporary investigators. It is stated that some diseases mentioned by others are synonymous with sprain. Brown or rust spots and net-necrosis are not accepted by the author. Attempts to isolate an organism have given negative results. Green manure and complete fertilizers appear to be beneficial while the cultivation of turnips accentuates the disease by inducing conditions in the soil. Varieties resistant to the disease are given.

\& Cortwijn, Bojjes J.

Aardappelziekten van het "stippelstreepen "topnecrose" type en het vraagsteek der latentie en physiologische specialisatie. (Potato disease of the streak and top necrosis type and the problem of latency and physiological specialization.) Nieded. Landbouwhoogesschool Wageningen 33(7) : 3-44, 1929. (Rev. Appl. Mycol. 9: 481, 1930.)

The "streak" of potato is a complex of virus diseases, including the following:

1. Stipplestreak Atanasoff which in a semi-latent form resembles Murphy's "crinkle", In some varieties it resembles mild mosaic.

In other varieties it is entirely masked.

2. Stipplestreak Koksiaan.

3. Stipplestreak Noordeling resembles crinkle but is not identical.

4. Stipplestreak Eersteling.

5. Topnecrosis latent in Duke of York.

6. Topnecrosis latent in Green Mountain.

7. Topnecrosis latent in the Dutch variety Monocraat.

8. Yellow Dwarf.

The author gives descriptions of all of these diseases.

\section{\& IMurphy, Paul A.}

Proposal for coordinating researches on the virus diseases of the potato. Proc. Int. Cong. Plant Sei. (Ithaca, N. Y.) p. 122, 1929 .

\section{Thung, T. H., \& Elze, D[avid] L[eon]}

"Pseudonet necrose" van de Aardappel. (Pseudo net necrosis of the potato.) Meded. Landbouwhoogeschool Wageningen. 33(9) : 1-10, 1929. (With English Summary.) (Rev. Appl. Mycol. 9: 483, 1930.)

The authors report an internal paranchyma necrosis both inside and outside the xylem ring; it is transmitted from the tuber by Myzus per- 
sicae. There are no foliage symptoms. It is similar to the "hereditary sprain" reported by Fruwirth. Atanasoff believes this disease to be the same as the net-necrosis in America and that it is associated with acuba mosaic. The authors do not agree with Atanasoff. It develops in storage with a rise in temperature from $10^{\circ}$ to $20^{\circ} \mathrm{C}$.

\section{\& Elze, D[avid] L[eon]}

American and European leaf roll of potatoes. Phytopathology (Abstract) 20(1): 137, 1930.

\section{Thung, T. H., \& Elze, D[avid] L[eon]}

Pseudonetnecrosis of the potato. Phytopathology (Abstract) $20(1): 137,1930$.

\section{\& Oortwijn, Botjes J.}

Diseases of the streak type in potatoes. Phytopathology (Abstract) $20: 138,1930$.

Thung, T. H., Elze, D[avid] L[eon], \& Likhite, V.

De virusziekten der Planten. (The virus diseases of plants.) Landbouw. 5(10) : 793-836, 1930. (With English summary.)

The methods of classification of plant viruses, and an attempt to classify and name potatoe viruses. Phytopathology 21(6): 577-613, 1931.

The author secured the cooperation of the leading workers on the subject all over the world. An extensive bibliography is appendixed.

Die selektion der kartoffel und der Euifluss äusserer Umstände, insbesondere der Düngung, auf das Selektionsergebnis. (Potato selection and the influence of external condition, especially of manuring, on the outcome of selection.) Ernährung der Pflanze 27(1) : 1-8, 1931.

The author summarizes reeent work by himself and his collaborators.

Methods of identification and differentiation of plant virus. Fifth Int. Bot. Cong. Cambridge, 1930: 383-386, 1930.

Les maladies á virus des plantes cultivées. (Virus disease of cultivated plants.) Second Inter. Cong. Path. Comp. (Paris) 1: 339, 1931.

A review of our knowledge of transmission, nomenclature and nature of virus diseases of plants. 
Die Autonomie der phytopathogen virusarten. (Autonomy of the plant pathogen of the virus kind.) Phytopath. Zeitschr. $4(2)$ : 205-224, 1931.

Important account with special reference to the potato. The author summarizes here his previous views on the nature of the phyto-genic viruses. His opinion in regard to the subject, is to attempt to unite the virus diseases under one collective heading, is opposed to the autonomous character of the phytopathogenic viruses.

Tabaks-mosaik en vervante ziekte. (Tobaceo mosaic and related diseases.) Ned. Tidjdschr. Hyg. Microb. Sewl. 5(4) : 182-191, 1931.

\section{\& Silberschmidt, $\mathbf{K}$ [arl]}

Ueber eine komplexe viruskrankheit der Tomato. (About a complex virus disease of tomato.) Phytopath. Zeitschr. 5(1):198, 1932.

A study of necrosis in some of the complex virus diseases.

A complex virosis of tobacco. Phytopathology (Abstract) 23 (1) : 28, 1933 .

Uber eine Komplexe Viruskrankheit des Tabaks. (On a complex virus disease of tobacco.) Phytopath. Zeitschr. 6(4) : 325-333, 1933.

Description of results obtained in continuation of previous work a sociated with Silberschmidt. The work is based on the effect of inoeulating tomato plants with two kinds of virus, namely, ordinary to. bacco mosaic and acronecrosis from outwardly healthy potatoes.

Onderzoek naar de vatbaarheid voor plantenziekten. (The investigation of susceptibility to plant diseases.) Tijdschr. over Plantenziekten 39(10) : 163-167, 1933.

Brief discussion on the possibilities offered by the investigation of varietal susceptibility in the control of plant viruses. Among those mentioned are potato virus disorders.

\section{Quar, Sut Ni.}

Observations on mosaic. Facts About Sugar 20:183-185, 1925.

\section{Raciborski, M[aryan]}

Over serehchtige ziekteverschijnselen (On the sereh disease phenomena.) Arch. Suikerindus. Nederl. Indië 6:10211026, 1898. 
Verlag Ontrent den stact van Sland Plantentium te Buitenzory over het jaar. p. 73-78, 108-110, 1899.

A new disease of elm. Seventh Nat. Shade Tree Conf. Proc. Ann. Meeting, Aug. 27, 28, 29, 1931, p. 79-82, 1931.

\section{Racicot H[oméra] N[oé]}

Report of the Dominion Field Laboratory of Plant Pathology. Ste. Anne de la Pocatiere, P. D. (Report Dominion Botanist for the year 1928 of Botany, Canada Dept. of Agric. 1929: 199-202, 1930. (Rev. Appl. Mycol. 9:502, 1930.)

Contains experiments on seed transmission of bean mosaic.

\section{Rama Rao, D. A., \& Sreeniyasaya, IVI.}

Contributions to the study of spike-disease of sandal (Santalum album. Lin. 4, 5. Part IV. Chemical Composition and spiked sandal stems. Journ. Indian Inst. Sci. 11A(19) : 24l247, 1929.

This paper gives the results of a chemical study of this disease.

\section{Rand, $F[$ rederick] V[ernon], \& Pierce, W[illiam] Dwight.}

A coordination of our knowledge of insect transmission. Phytopathology $10: 187-231,1920$.

A very excellent discussion of the subject and a bibliography of 173 titles.

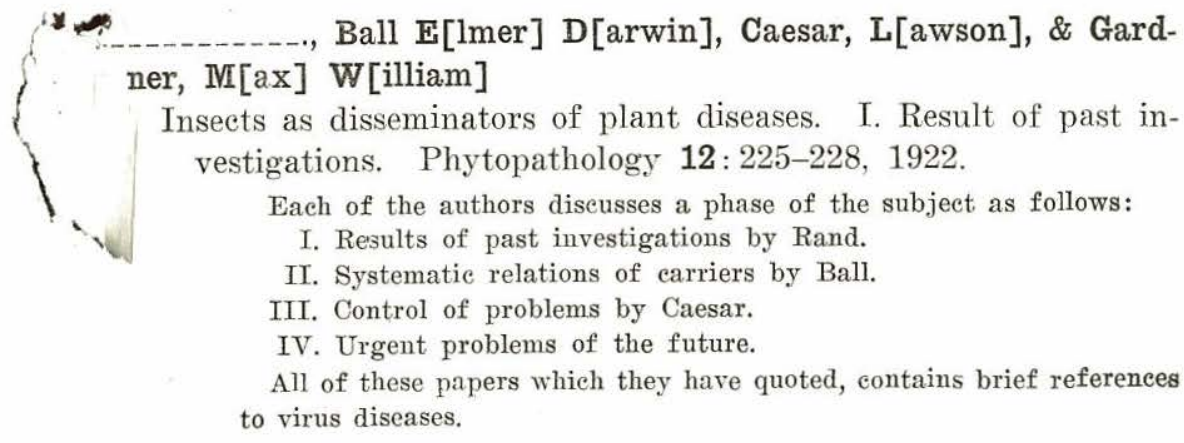

Pecan rosette: Its histology, cytology and relion to other chlorotic discases. U.S.D.A. Bul. 1038, 42 p., 1922.

A very thorough study of the disease with special attention to the histology, eytology and relation to other chlorotic diseases.

Status of pecan rosette. Amer. Nut. Journ. 16:56-57, 1922. 


\section{Rands, $\mathbf{R}$ [obert] D[elafield], \& Sherwood, S[idney] F[orsythe]}

Yield tests of disease-resistant sugar cane in Louisiana. U.S. D. A. Dept. Circ. 418, 18 p., 1927. (Rev. Appl. Mycol. 6: 752, 1927.)

\section{\& Stevens, F[rederick] $\mathbf{D}[$ elos $]$}

Sugar-cane variety tests in Louisiana during the crop year 192627. U. S. D. A. Circ. 36, 1928.) (Rev. Appl. Mycol. 8(1) : 62, 1928.)

This paper gives the results of field mill tests of canes that are mosaic-tolerant to determine their relative values.

\& Summers, Eaton III.

Studies on apparent recovery of certain sugar-cane varieties from mosaic in Louisiana. Fourth Congress Interna. Soc. SugarCane Technologists, Puerto Rico, 1932. Bull. 123, 7 p., 1933.

This paper presents some field observations and experimental evidence on apparent recovery from mosaic of commercial sugar-cane varieties in Louisiana.

\section{Rangel, E[ugenio dos Santos]}

O combate ao mosaico. (Mosaic disease control.) Bol. Agric. Bahia 1926: 26-24, 1926.

O combate ao mosaico. (Mosaic disease control.) A. Lavoura 30 : 203-204, 1926.

Rankin, W[illiam] H[oward], Hockey, J[ohn] F[rederick], \& McCurry, J[ohn] B [ruce]

Leaf curl and mosaic of the cultivated red raspberry. Phytopathology (Abstract) 12:58, 1922.

Mosaic and leaf curl of the cultivated red raspberry. Dom. Expt. Farm; Div. Bot. Cire. n.s. 1, 1922. (Phytopathology 12(6) : 253-264, 1922.)

Very complete description of these diseases which appear to be carried by Aphis rubiphila.

Raspberry mosaic and mosaic-free planting stock. N. Y. State Hort. Soc. Proc. 68: 272-280, 1923.

This disease is the most important cause of low yields. The author gives descriptions, a discussion of methods of transmission, methods of control and other interesting data.

Running-out of raspberries. New York Agric. Expt. Sta. Circular 67, 12 p., 1923.

This is attributed to mosaic, leaf curl and rosette. 
Raspberry diseases. N. Y. Hort. Soc. Proc. 69: 139-145, 1924. Popular.

Raspberry mosaic and blue stem. New York (Geneva) Agrie. Expt. Sta. Circ. 75, 4 p. 1924. Popular.

Raspberry mosaic control in the Hudson River Valley. New York Hort. Soc. Ann. Meet. Proc. 71: 173-178, 1926. Popular.

Mosaic of raspberries. New York (Geneva) Agric. Expt. Sta. Bull. 543: 60 p., 1927.

The author describes the symptoms, gives results of roguing, rate of spread, varietal susceptibility and much other important data, including experimental proof that the important vectors are Aphis rubiphila and Amphoraphora rubi.

Mosaic of red and black cultivated raspberries. Phytopathology (Abstract) 17(1): 46, 1927.

Probable identity of red and mild mosaic of black raspberries. Phytopathology (Abstract) 20:125-126, 1930.

Virus diseases of black raspberries. New York (Geneva) Agrie. Expt. Sta. Tech. Bull. 175, 24 p., 1931. The writer classifies the raspberries mosaic.

Raspberry mosaic control in the Hudson Valley, New York. Agric. Expt. Sta. Circ. 142, 4 p. 1934. Popular.

Rao, P. S.

The cause of spike in sandal (Santalum Album.) Indian Forester 46: 469-487, 1920.

The disease may depend on sap density of the parent plant; therefore, an abnormal physiological reaction. Gives reason for his opinion.

Physiological anatomy of the spiked leaf in sandal. Indian Forester 47 : 351-360, 1921.

Gives a discussion of the structure and refers to the increase in starch, especially in the older leaves. 


\section{Rao, Rama}

Field investigations of spike in sandal on the Kollimalai hills. Indian Forester 44: 58-65, 1918.

Spike disease was found 80 miles from infested area. Observations on the ecological conditions are given with a list of 57 lots of sandal trees.

Rao, Y. V. S.

Contribution to the study of the spike-disease of Sandal (Santalum album Linn.) Part XIII. Investigations of the hexone bases. Part XIV Study of mosaics associated with mosaic areas. Journ. Indian Inst. Sci. 16A(8):91-95, 1933.

Report of analysis of healthy and diseased leaves of sandal as to nitrogen, amino acids, histidine and histamine contents.

Biochemical studies of Gislkia and Ageratum mosaics in relation to spike of sandal areas.

Rapson, C. J.

Control of streak disease in Uba Cane. Proc. 3rd Ann. Congr. South African Sugar Assoc. p. 10-12, 1925. (South African Sugar Journ. Ann. p. 154-157, 1925.)

Rathschlag, $\mathrm{H}$.

Mosaik krankheit an der dahlia. (Dahlia mosaic disease.) Blumen N. Pflanzenb. 44:148, 149, 1929.

Mosaikkrankheit an salat. (Lettuce mosaic disease.) Obst. u. Gemüseb. u. $75: 114,115,1929$.

\section{Ravn, $\mathbf{F}$ [rederik] K[olpin]}

On mosaiksygen og beslaegtede Plantessygdomme. (Mosaic disease and allied plants diseases.) Nord. Jordbrugrforsk 1:1024, 1919 .

\section{Rawlins, T[homas] $\mathbb{E}[$ lsworth], \& Johnson, James.}

Cytological studies of the mosaic disease of tobacco. Amer. Journ. of Botany 12(1) : 19-32, 1925. (Phytopathology (Abstract) $14(1): 55-56,1924$.)

A discussion of three types of bodies found in cells of mosaic plants.

Cytology of root tips from sugar beets having curly-top disease. Phytopathology (Abstract) 16(10): 761, 1926.

Research on viruses causing plant diseases. Science n.s. 65 (1686) : 398, 1927.

A very short paper on the nature of filterable viruses in which the author suggests several lines of research. 


\section{\& Horne, W[illiam] T[itus]}

A graft infectious disease of the cherry. Phytopathology (Abstract) $20(10): 853,1930$.

\section{\&}

"Buckskins", a destructive graft-infection disease of the cherry. Phytopathology 21(3) : 331-335, 1931.

A disease of cherries in northern California which is transmitted by grafting.

\section{Ray, J[ulien Charles IMichel]}

Sur les maladies de la canne á sucre. (The diseases of sugar cane.) Bull. Soc. Mycol. France 12(4) : 139-143, 1896.

\section{Read, W. H.}

Physiological investigations of mosaic disease of the tomato. Expt., \& Res. Sta. Cheshut Herts., 1931, Ann. Rpt., 17:44, 1932.

A preliminary report indicates that total and reducing sugar rise for about 8 days and begin to fall after 20 days.

Physiological investigations of mosaic disease of the tomato. Expt. \& Res. Sta. Cheshut Herts, 1932. Ann. Rpt., 18: 45-48, 1933.

Continuation of previous work.

\section{Reddick, Donald, \& Stewart, V[ern] B[ohnam]}

Varieties of beans susceptible to mosaic. Phytopathology 8(10): 530-534, 1918.

The authors give the results of many tests which indicate that field selection of apparently healthy seed does not control the disease.

\&

Transmission of the virus of bean mosaic in seed and observations of thermal death-point of seed and virus. Phytopathology, 9(10) : 445-450, 1919.

The disease is transmitted by rubbing the leaves of young plants with crushed leaves from diseased plants but not by injecting. Dry heat range from 50 to $80^{\circ}$ C. ( 1 to 24 hours) reduced germination but did not kill the virus.

, \&

Additional varieties of beans susceptible to mosaic. Phytopathology, 9(3) : 149-152, 1919.

Gives the records of additional work. 
A hybrid bean resistant to anthracnose and to mosaic. Phytopathology (Abstract) 12(1):47, 1922.

La transmisión du virus de la mosaïque du Haricot par le pollen. (The transmission of mosaic virus in Kidney beans by the pollen.) Second Cong. Inter. Path. Comp. (Paris) 1:363366, 1931.

The mosaic disease of beans (Phaseolus vulgaris) is transmissible by pollen.

A potato disease. Phytopathology 23(7):622-624, 1933.

Brief note describing a disease which seems to be due to a virus.

Redpath, W. H.

A planter's experience with mosaic disease and the planting of Uba Cane. Journ. Jamaica Agric. Soc. 29(1) : 18-21, 1925. (Rev. Appl. Mycol. 4:442, 1925.)

\section{Reed, H[oward] S[prague], \& Craybill, C[harles] H[arvey]}

Notes on plant diseases in Virginia observed in 1913 and 1914. Virginia Sta. Tech. Bull. 2:37-58, 1915.

Reesema, Geerts van, et al

Mosaic disease in Java. P. O. J. canes not immune. (A review of a technical article in Java.) Archief. 32:301-309. (Facts About Sugar 19(21) : 496, 1924.)

Reid, Katherine W[illess]

Variegated Abutilons. Journ. New York Bot. Garden 15:207213, 1914 .

A historical discussion.

Reiling, $\mathrm{H}$.

Einige neuere Virus-Krankheitsformen. (A new virus disease form.) Deutsche Landw. Presse 55(15) : 219, 1928.

Beiträge zur kenntnis der Viruskrankheit der Kartoffel. (Contribution to the study of virus diseases of the potato.) Pflanzenbau 5: 284-290, 1929.

Reincke, $\mathbf{R}$.

Experimentaluntersuchungen über die Chlorose del gelben Lupine. (Experimental investigations about chlorosis of yellow lupin.) Dungg. Bodenkd. A. 23: 77-104, 1931. 
310 THE JOURNAL OF AGRICULTURE OF THE UNIVERSITY OF P. $\mathrm{R}$.

\section{Reinking, Otto A[ugust]}

A Disease of Economic Plants in Southern China. The Phil. Agricul. 8:109-134, 1919.

A popular discussion.

Fiji disease of cane. Sugar Cent. and Planters' News. Philippine Is. 1(1) : 15-20, 1920. (Facts About Sugar 12:272-273, 1921.)

Diseases of sugar cane in the Philippines. Sugar Cent. and Planters' News, 1(2):41-48, 56, (3)94-120, (8) : 335-336, (14) 22-30, 35-39, 43, 1920, (15) : 18-22, 2(5) : 190-191, 1921. Popular.

Fiji diseases of sugar cane. Sugar Cent. \& Planters' News. 2 (2) : 41-48, 1921.

Gives a description and states that the disease is very destructive. Some varieties are very resistant.

Fiji disease of sugar cane in the Philippine Islands. Phytopathology 11(8) : 334-336, 1921.

\section{Reitmair, Otto}

(The leaf-roll disease of the potato.) Ztschr. Landw. Versuchws. Osterr., 13(1) : 48-52, 1910.

Biologische Studien uber die Blattrollkrankheit der kartoffel. (Mitteilungen des Komitees zum Studium der Blattrollkrankheit der Kartoffel, No. 4). (Biological studies about the leafroll disease of potato. Report of the committee for the study of potato leaf-roll disease No. 4.) Zeitschrift fur des Landw. Versuchs. Oesterr., Jahrg. 15(1) : 1-106, 1912.

(Report of the committee for study of leaf-roll-VII Biology of the potato plant with particular reference to leaf-roll.) (Ztsch. Landw. Ver. Ostrr., 16:(6) 653-717, 1913.

Remy, L.

Mutation in mosaïque. (Mutation on mosaic.) Compt. Rend. Acad. Sci. Paris 187 : 607-609, 1928.

\section{Remy, Th[eodere] \& Schneider, G[eorge]}

Beobactilungen uber das auftreten der Blattrollkrankheit. Fuhlings Landswirts Zeitung, Jahrg. 58(6) : 201-219, 1909. 
Die mosaikkranheit der Kartoffel. (Mosaic disease of potato.) Veroffentl. Landw. Ammer Rheinprov. No. 2: 93-95, 1919.

Reyes, G[audencio] IVI.

Mosaic disease of sugar cane. Philippine Agric. Rev. 20(2): 187-228, 1927. (Rev. Appl. Mycol. 7: 197, 1928. Facts About Sugar 23:34, 1928 . U. S. D. A. Expt. Sta. Rec. Abs. 59: 643, 1928.)

A history of the disease in the Philippine Islands with discussion of methods of control including a list of resistant varieties.

\section{Reynolds, Ernest Shaw.}

Two tomato diseases. Phytopathology 8: 535-542, 1918.

Leaf chlorosis is regarded by the author as the so-called mosaic. Was unable to transfer it by rubbing; external application of iron salts failed. One of the diseases in this paper is a chlorosis which the author describes as a new virus disease.

\section{Richards, B[ert] L[orin]}

A new and destructive disease of the potato in Utah and its relation to the potato Psyllid. Potato Ass'n Amer. Proc. 14: 94, 1928. (Phytopathology (Abstract) 18(1):140-141, 1928.)

Description of the disease and a report of its spread. Associated with the potato psyllid (Paratrioza cockerelli).

Botany and plant pathology in Utah. Utah Agric. Expt. Sta. Bull. 209 : 44-51, 1929.

Notes on leaf-roll and mosaic diseases of potatoes, psyllid yellows, mosaic and western blight of tomatoes.

Further studies with psyllid yellows of the potato. Phytonathology (Abstract) 21(1): 103, 1931.

\section{\& Blood, H[eber] L[oran]}

Psyllid yellows of the potato. Journ. of Agric. Res. 46: (3): 189-216, 1933.

The authors give the history, description of this disease which is associated with Paratrioza cockerelli. In their summary they say: "The true nature of the infective principle injected into potato plant by Paratrioza cockerelli at present remains unknown. Available facts, however, question somewhat the virus theory of the disease and suggest the possible existence of some toxic substance which is produced in some way during the feeding process of the psyllid nymphs. Additional facts will be necessary before final conclusions can be drawn as to the true etiology of psyllid yellows." 


\section{Richardson Kuntz, P[edro Alejandro]}

Estudios comparativos de las cañas Kavangire, Zuinga y Cayanna 10. Ins. Expt. Sta. Puerto Rico. Circ. 73, 11 p., 1923. Popular comparative descriptions of these varieties and reference to its tolerance to sugar-cane mosaic.

La producción de nuevas variedades de caña y sus resultados experimentales. (Sugar-cane varieties production and its experimental results.) Ins. Expt. Sta. Puerto Rico Bull. 28, 67 p., 1931.

Popular information of data of experimental field tests of new varieties of sugar cane in regard to susceptibility and immunity to the mosaic disease.

El mosaico en las nuevas variedades de caña de azúcar P. R. 803: P. R. 807 ; F. C. 916 y S. C. 12(4). (Mosaic on the new sugar-cane varieties. P. R. 803; P. R. 807; F. C. 916 and S. C. 12(4). Ins. Expt. Sta. Puerto Rico Cire. 96, 10 p., 1932.

Field test to try the above-mentioned varieties in regard to mosaic immunity. P. R. 803 and F. C. 916 are highly tolerant, P. R. 807 commercial immune and S. C. 12(4) used as check highly susceptible. Results given in tabular form.

Resistencia relativa al matizado de cañas producidas en el país comparadas con las importadas. (The relative resistance to mosaic of native grown and imported canes.) Ins. Expt. Sta. Puerto Rico. Cire. 101, 23 p., 1932.

Full details are given of the author's comparative observations on the relative productivity and resistance to mosaic of the locally produced and imported sugar-cane varieties in Puerto Rico. He reports that the Puerto Rico seedlings P. R. 803 and 807 and F. C. 916 were superior both in regard to yields and resistance to mosaic. Among the foreign, P. O.J. 2878 proved superior to B. H. 10(12) and S. C. $12(4)$ in both respects.

Cane varieties in Puerto Rico. Facts About Sugar 27(12) : 530532, 1932.

The author emphatically states that mosaic is the only sugar-cane disease of real economic importance in Puerto Rico. He also assures that its control, to day, presents virtually no difficulty.

\section{Ridler, W[inifred] F[rances] F[urze]}

The structure of reverted black eurrants. Univ. Bristol Ann. Rpt. Agric. \& Hort. Res. Sta. p. 73-74, 1923.

The diseased plants have less vascular tissue and more medullary ray tissue than the healthy plants. The diseased plants also produce a 
gum which blocks the conducting tissues. The fruits from diseased plants contain less vascular tissues than those from healthy plants.

Investigation of the structure of reverted black currants. Ann. Appl. Biol. 11(2) : 252-260, 1924.

The author states that no actual qualitative differences in structure have been observed between normal and reverted plants of black currants (Ribes nigrum). The most marked difference is in amount of gum and wood.

\section{Rietsema, J.}

Weinig bekende ziekten in kers, Pruim en Persik. (Little known diseases in Cherry, Plum and Peach.) Tijdschr over Plantenziekten 36(11) : 261-266, 1930.

Cherry and plum virosis is sometimes associated with a form of

Riha, J. mosaic.

(Correlation coefficient for estimating the reduction in yields caused by the more important of our potato diseases.) Ochrana Rostlin, Prag. 8: 58-61, 1928.

(Is the mosaic disease of potatoes as injurious as leaf roll?) Zemedesky Arch. Prag. 19(3-4) : 134-140, 1928.

Rischkow, V[itolij] L. *

Neue Daten über geaderte Panaschierung bei Evonymus japonicus und Evon. radicans. (New data on veined mottling in Evonymus japonicus and E. radicans.) Biol. Zentralbl. 47 (12) : 752-764, 1927. Rev. Appl. Mycol. 9(3) : 195, 196, 1930.) The chlorosis is transmitted by grafting but not by insects.

(Infectious chlorosis in $E$. japonicus and $E$. radicans.) Journ. All-Russ. Congr. Bot. Leningrad (Abstract) p. 184-185, 1928. \& Karatschewsky, I. K.

Chlorophyllmangel und Erzymwirkung I. Katalasewirkung bei Panaschierung und Mosaikkrankheit. (Chlorophyll deficiency and enzymatic action I. Catalese action in variegation and mosaic diseases.) Beitr. Biol. der Pflanzen. 20(3) : 199220, 1933.

Extensive account well illustrated with tables. Gives also results with other variegated plants.

\section{Rivas, Dámaso}

Filterable Viruses Peculiar to Plants. Human Parasitology, p. 222-223, 1920.

\footnotetext{
* Also appears as Rizhkov, V. L.
} 


\section{Rivers, Thomas IM.}

Filterable viruses. A critical Review. Journ. Bact. 14:217255, 1927.

The Nature of viruses. Physiol. Rev. 12(3):423-452, 1932.

\section{Robb, W.}

Scottish Society for Research in Plant Breeding. Report of the Director of Research to the Annual Meeting 13th July 1933, 32 p., 1933.

This report deals entirely on the behaviour of virus diseases of the potato plant with special reference on leaf-roll disease.

\section{Robbins, Wilfred William}

Mosaic disease of sugar beets. Phytopathology (Abstract) 11 (1) : 48, 1921 .

Mosaic disease of sugar beets. Phytopathology 11(9) : 349-365, 1921.

Gives a description of a disease which is different from curly top. The disease is carried by Myzus persicae. It is carried over winter in the siloes.

Robertson, N. F.

Mycology. Report Dept. Agric. Burma, 1927, p. 11-12, 1927. (Rev. Appl. Mycol. 7: 559, 1927.)

A brief reference to sugar-cane mosaic in three new localities.

\section{Robertson, J. N., \& Smith, A. IM.}

A study of the hydrogen-ion concentration of the potato tuber. Biochem. Journ. 25(3) : 763-769, 1931.

\section{Rochlin, Emilia, J.}

Zur anatomie der mosaikkranken kartoffel pflanzen. (On the anatomy of mosaic diseased potato plants.) Phytopath. Zeitschr. 2(5) : 455-468, 1930. (Materials for Mycol. \& Phytopath., Leningrad. 8(2) : 145-154, 1931.)

These studies show structure changes in the phloem of leaf-roll, rugose mosaic, curly dwarf and stipple streak. Also some changes in the medullary and cortical tissue.

\section{Rosa, Joseph Tooker}

Chemical changes accompanying the western yellow blight of tomato. Plant Physiology 2(1) : 163-169, 1927.

The chemical changes in the tomato eaused by this disease are different from those eaused by the same virus (curly top) in sugar beets. 


\section{Rosen, $\mathrm{H}$ [arry] $\mathrm{R}$ [oberts]}

Mosaic disease of sweet potatoes. Arkansas Agric. Expt. Sta. Bull. 167, 10 p., 1920.

Disease first recognized by the author in 1918. It is a hereditary but non-infectious chlorosis. Recommendations for control.

Corn mosaic in Arkansas. Phytopathology (Abstract) 12(5): 250, 1922.

Mosaic disease of corn in Arkansas. Phytopathology (Abstract) $12(5): 252,1922$.

Sweet potato mosaic and its incubation period of two growing seasons. Phytopathology (Abstract) 16(1):74, 1926.

The mosaic disease of sweet potatoes with special reference to transmissibility. Arkansas Agric. Expt. Sta. Bull. 213, 16 p., 1926.

This paper gives the results of inoculation experiments which show that the disease develops very slowly. The conditions for its spread are much better in the southern than in the northern States.

\section{Rosenfeld, $\mathbf{A}$ [rthur] $\mathbf{H}$ [inton]}

Kavangerie: Puerto Rico mosaic disease-resisting cane. Int. Sugar Journ. 22 : 26-33, 1920.

Aspecto beneficioso del mosaico de la caña de azúcar. (Beneficial aspect of the sugar-cane mosaic disease.) Rev. Agric. Puerto Rico 12:7-14, 1924. (Int. Sugar Journ. 26(304): 191-195, 1924.)

La causa del matizado. Un paso hacia la solución de este misterio. (The Cause of Mosaic. One step toward the solution of this mystery.) Rev. de Agricultura de Puerto Rico 13(3): 145-148, 1924; (Int. Sugar Journ. 26(310) :535-536; Facts About Sugar 19(18): 425. Trop. Agric. 64(1):38-40, 1925.)

"The Java P. O. J. canes in Tucumán and Puerto Rico." Dept. Agric. Journ. Ins. Expt. Sta. Puerto Rico 8(3): 1-44, 1925.

Selección de caña para la plantación. (Sugar-cane selection for the planting.) Sugar 28(3): 153-155, 1926. 
A monograph of sugar-cane varieties. Journal Dept. Agric., P. R. Vol. XI, 1927.

Contains some data on mosaic.

Lessons from the renaissance of a Sugar Industry. Int. Sugar Journ. 29(348) :634-641, 1927. (Rev. Appl. Mycol. 7:400-. 401, 1927.)

The author discusses the relationship of mosaic to varieties.

\section{Rosenthal, H.}

Viruskrankheit bei schwarzen Johannisbeeren. (Virus disease of black currants.) Obst-und Gemüseban, 76(1):14, 1929. (Rev. Apply Mycol. 9: 394, 1930.)

A brief note on the reversion of black currants in Holland.

Rouzinoff, P. G.

(Some data on the physiology of potato leaf-roll.) Morbi Plantarum, Leningrad 19(3-4) : 148-159, 1920.

The experiment discussed by the author was with the view to find a rapid laboratory method for determining the virus diseases in potato plants.

\section{Roxas, IM[anuel] L[uz]}

Select your cane points for seed. Sugar Central \& Plant News, $1: 16,17,1920$.

\section{Rozhdestvenskij, N. A.}

(Virus diseases on potatoes and other plants.) Journ. All-Russ. Congr. Bot. Leningrad (Abstract) p. 183, 1928.

Ruggles, Arthur Gordon, \& Winter, J. D.

Aspects of mosaic of the red raspberry from the standpoint of the nursery inspector. Minnesota Hort. 54:79-85, 1926. (Journ. Econ. Ent. 19(2) : 365-370, 1926.)

Field observations and discussions.

Results of three years' experience in the control of mosaic in red raspberries in nurseries. Journ. Econ. Ent. 20(3) :478483, 1927.

The author gives the results of roguing experiments which led to the conclusion that the disease can be controlled in this manner.

\section{Rusconi, A.}

Osservazioni e considerazioni sulla clorosi del pesco nell. Albeiganese. La Costa Azzura Agr: Floreale, Sanremo 18(9): 324-327, 1933. 


\section{Rutgers, $\mathbf{A}[$ braham] $\mathbf{A}$ [rnold] L[odewyk]}

Die krulziekye van katjang tanah (Arachis hypogaea.) Meded. v. d. Afdeeing v. Plantenziekt. 6:1-5, 1913.

\section{Salaman, $\mathbf{R}$ [edcliffe] $\mathbf{N}$ [athan]}

Degeneration of potatoes. Int. Potato Conference Roy. Hort. Soc. Ann. Rpt. p. 79-90, 1921.

Believes that "running out" is not due to vegetatively propagation but to mosaic- which has for years been known as "curl".

Potato seedling mosaic. Brit. Assoc. Adv. Sci. Rpt. (Abstract) 91: 493-494, 1923.

Degeneration of the potato. An urgent problem. Journ. Nation. Inst. Agric. Bot. 3:39-51, 1925.

A note on the production of premature sprouting in the potato and its application to the study of virus diseases. Journ. Agric. Sci. 17(4) : 524-529, 1927.

Gives the results of physiological experiments.

Virus diseases of the potato; Streak. Nature 126(3172): 241, 1930.

The relationship of streaks to some other virus diseases.

Crinkle "A" an infectious disease of the potato. Proc. Roy. Soc. London ser. B. 106(B741):50-83, 1930. (Rev. Appl. Mycol. 9: 603, 1930.)

The author describes this disease and gives proof that it is caused by a virus.

\section{\& Le Pelley, R[ichard] H[enry]}

"Para-crinkle": a potato disease of the virus group. Proc. Roy. Soc. London ser. B. 106(13) : 140-175, 1930.

The authors give the results of experiments on virus diseases, with special attention to "crinkle A."

Les maladies á virus de la pomme de terre. Leur analyse et leur synthése. (The virus disease of potato. Its analysis and its synthesis.) Second Inter. Cong. Comp. Path. Fac. Méd. Univ. Paris 1: 451, 1931.

Bawden, F. C.

An analysis of some necrotic diseases of the potato. Proc. Roy. Soc. London. ser. B. 111 (B769) : 53-73, 1932. 
The authors review the literature on streak disease of the potato. They accept Quanjer acropetal necrosis as a symptom of stipple streak and of acronecrosis or top necrosis. They also discuss symptoms produced by Kenneth M. Smith's $X$ and $Y$ viruses.

The analysis and synthesis of some diseases of the mosaic type; the problem of earriers and auto-infection in the potato. Proe. Roy. Soc. ser. B. 110(B766) : 186-224, 1932.

An extensive account deseribing in detail experiments in which the author has obtained evidence that, besides Smith's $X$ and $Y$ viruses, there is a third element which he designates the $\mathrm{Z}$ virus. He made cytological studies and summarizes recent developments.

Protective inoculation against a plant virus. Nature 131(3309): 468, 1933.

Description of experiments carried by the author, on inoculations with plant viruses.

\section{Salmon, E[rnest] S[tanley]}

Fifth report on the trial of new varieties of hops 1921. East Malling Res. Sta. 1922.

Mosaic disease of hops. Journ. Min. Agric. 29(10) : 927-934, (Journ. Inst. Brewing 29:882-889, 1923.)

A discussion of this disease which is evidently due to a virus.

Sixth report on the trial of new varieties of hops. East Malling Res. Sta., 1923.

A continuation of the proceedings.

Seventh report of the trial of new varieties of hops, 1923. Journ. Inst. of Brewing 30(8): 671-689, 1924.

Eighth report on the trial of new varieties of hops. East Malling Res. Sta. p. 33, 1925.

\section{\& Ware, W[illiam] II[elville]}

Virus diseases and the grafting of the hop. Gard. Chron. ser. 3, 77(2002) : 320-322, 1925.

\section{\& Wormald, $\mathrm{H}$.}

Diseases of the hop crop. Min. Agric. Misc. Publ. 42:41-58, 1925.

Notes on a visit to the hop growing districts of Bohemia. Czechoslovakia Journ. Inst. of Brewing 31(10) : 514-521, 1925. 
Eleventh report on the trial of new varieties of hops, 1926. East Malling Res. Stat. Kent. 34 p., 1927.

Notes on the ten new seedling varieties of hops used in the brewing experiments at Nanchester, 1926. Journ. Inst. Brewing $33: 570,1927$.

Notes on three varieties of hops. Journ. Inst. Brewing n. s. 33: 12-14, 1927.

Tenth report on the trial of new varieties of hops. East Malling Res. Sta. p. 34, 1927.

\section{\& Ware, W[illiam] $\mathbb{M}$ [elville]}

The mosaic disease of the hop; grafting experiment I. Aun. Appl. Biol. 15(3) : 342-351, 1928.

The authors give the results of grafting experiments.

Inter-specific grafting in Humules. Gard. Chron. ser. 3. $83: 396$, 1928.

Twelfth report on the trial of new varieties of hops, 1928. Journ. Inst. Brewing, n. s. 26(11) : 523-532, 1929. (Rev. Appl. Mycol. 9(2):130-131, 1930.)

A record of a severe outbreak of mosaic.

\section{\& Ware, W[illiam] III[elville]}

Report from the Mycological Department. Journ. South Eastern Agric. Coll. Wye., Kent., 26:165-172, 1929. (Rev. Appl. Mycol. 9(1) : 15, 1930.)

Brief reference to diseases of potatoes and hops that may be viruses. \&

The chlorotic disease of the hop, I. Ann. Appl. Biol. 17(2): 241-247, 1930.

The authors describe a new hop disease of the virus group and propose the names "Chlorotic disease" for its physical appearance. Two instances to record where the disease is transmitted artificially.

The chlorotic disease of the hop, II. Ann. Appl. Biol. 19(1): 6-15, 1932.

Continuation of previous work. Studies on transmissibility of this type of virus disease which is observed to be easily transmitted by grafting, budding and rubbing juice from infected plants on wounded 
surfaces of healthy plants. This behaviour clearly distinguishes the chlorotic disease from the other two virus diseases of hops, i. g. mosaic and nettlehead, which up to the present are only transmitted by grafting.

The chlorotic disease of hop, III. Ann. Appl. Biol. 19(4) : 518528, 1932.

This disease is transmitted by grafting. The authors give the results of experimental work.

Mycological Department. Journ. South Eastern Agric. Coll., Wye, Kent. 29 : 15-22, 1932.

\section{Samson, $\mathbf{R}$ [ayburn] W[alter]}

A study of the properties and nature of the virus of the spindle tuber disease of potatoes. Unpublished Thesis Univ. Nebraska Library, 1927.

Relation of Jimson weed to certain viruses of tomato and potato. Phytopathology (Abstract) 20(1) : 136, 1930.

\section{Samuel, G[eoffrey]}

Nature of disease-producing viruses. Nature 125(3141):51, 1930. (Rev. Appl. Mycol. 9:397, 1930.)

\section{A [mbrose Jaques]}

Bald, J[ames] G[rieve], \& Pittman, H[arold]

Investigations on "Spotted wilt" of tomatoes. Commonwealth of Australia Council for Sci. \& Ind. Res. Bull. 44, 64 p., 1930.

This paper gives a description of the disease, results of experiments on transmission and other host plants. The disease is carried by Frankliniella insularis.

Tomato diseases in South Australia and how to control them. Journ. Dept. Agric. South Australia 34(2):154-156; (3): 253-272; (4) : 369-377; (5) : 499-510, 1930.

Spotted wilt and streak on tomato is reported. Mosaic appears to be a glasshouse disease.

Summary of plant disease records in South Australia for the two years ending June 30th, 1930. Journ. Agric. South Australia $34: 746,1931$.

Brief note on turnip mosaic. 
$\&$

Thrips tabaci as a vector of plant virus disease. Nature 128 (3229) : 494, 1931.

The authors confirm the work of Pittman and K. M. Smith that the spotted wilt of tomato is carried by Thrips tabaci but find that Frantliniella insularis can not transmit it, except in the larval stage.

Some experiments on inoculating methods with plant viruses, and on local lesions. Ann. Appl. Biol. 18(4) : 494-507, 1931.

The author inoculated tobaceo plants with cucumber mosaic and yellow tobaceo mosaic by means of light rubbing without visible injury and by scratching with a needle. The former method was more successful than the latter. This supports the work of Holmes.

\section{\& Bald, J[ames] G[rieve]}

On the use of the primary lesions in quantitative work of two plant viruses. Ann. Appl. Biol. 20(1) : 70-99, 1933.

The authors used the method devised by Holmes. They say, "Tomato spotted wilt forms necrotic primary lesions on the leaves of tobacco of a character suitable for quantitative work, and a number of the results obtained with tobacco mosaic have been checked with this virus." They discuss the method and results.

, \&

Tomato spotted wilt of tomatoes. Journ. Dept. Agric. South Australia 37 (2) : 190-195, 1933.

A brief article, well illustrated describing South Australia tomato spotted wilt which is transmitted by Franteliniella insularis and Thrips tabaci. Control measures are recommended.

\section{\& Eardley, C. II.}

"Big bud" a virus disease of the tomato. Phytopathology 23 (8) : 641-653, 1933.

This disease was originally named "tomato rosette" by Cobb. The authors describe the abnormalities produced by the disease in tomatoes and state that it was not possible to transmit it by mechanical inoculation, but readily by budding and grafting. The shortest incubation period being 28 days. The insect vectors of the disease have not yet been discovered. It was found that Solanum nigrum showed similar symptoms to those of diseased tomato plants, but it was not possible to transmit it to tobacco or Nicotiana glutinosa.

The movement of tobaceo mosaic virus within the plant. Ann. Appl. Biol. 21(1) : 90-111, 1934.

A well illustrated work based on Holmes' studies on the subject. 


\section{Sandsten, E[mil] P[eter], \& Tompkins C[hristian Milton]}

Degeneration in Colorado potatoes. Colorado Agric. Expt. Sta. Bull. 278 : 3-15, 1922.

A popular discussion of losses.

\section{Sartory, Gratiot, \& Thiébant.}

Sur le rajeunissement de la pomme de terre. (On the rejurenence of the potato.) Comptes Rendus Acad. Sci. 158:45, 1914.

Sastri, B. N., Sreenivasaya, II., \& Iyengar, J. V. V.

Contributions to the study of spike disease of sandal. (Santalum. album Linn.) VII.-Factor influencing diastatic activity. VIII.-Chemical composition tissue fluids from the leaf. IX. -Chemical composition of tissue fluids from the stem. $X$. - Seasonal studies on healthy and partially spiked trees. Journ. Indian Inst. Sci. 12A (17) : 233-250, 295-305. 1929.

The diseased plants have a higher diastatic activity than the healthy plants.

Note on the starch-liquefying action of Sandal leaf extracts. Indian Inst. Sci. 12A : 251-252, 1929. (Rev. Appl. Mycol. 9: 277, 1930.)

The studies on the spike disease suggested that the accumulation of starch in the leaves was caused by failure to liquefy. Studies on hydrolysis of potato starch by extracts from healthy and diseased leaves showed that more starch liquefied in the healthy than in the diseased leaves.

\section{\& Narayana, $\mathbf{M}$.}

The spike disease of Dodonacea viscosa. Journ. Inst. Indian Sci. 13A (12) : 147-152, 1931.

Results are given and discussed as to the constituents of healthy and diseased plants.

\section{Saunders, A[braham] R[amie]}

Some aspects of the virus disease problem in plants. South African Journal Sci. 23: 295-304, 1926.

Sauri, F.

El mosaico de la caña de azúcar. (Sugar cane mosaic.) Rev. Agric. Rep. Dominicana. 18(6) : 101-104, 1923. Popular.

Durch welche Mitted treten wir der Blattrollkrankheit und ähnlichen Kartoffelkrankheiten entgegen? (Through which 
means do we treat against leafroll and similar diseases?) Fühlings Landw. Zeitg. 1916.

\section{Savastano, Giulio}

Il mosaico del Fagiolo in Italia. (Bean mosaic in Italy.) Boll.

R. Staz. Pat. Veg. n. s. 12(4) : 377-394, 1932.

The author accounts for the symptoms, distribution, probable nature, and types of bean mosaic. Gives methods of control.

\section{Sayer, Wynne.}

Mosaic and its control in other cane growing countries. Agric. Journ. of India. 24(1) : 25-31, 1929. (Facts About Sugar 24: 371, 1929. Rev. Appl. Mycol. 8: 404, 1929.)

An exposition of data and facts for every country.

\section{Schaffnit, J[ohannes Martin] E[rnst Christian Otto]}

Zur erforschung der Mosaikkrankheiten. (Investigation of mosaic disease.) Angew. Botanik. 8(5) : 304-313, 1926.

The author gives a general discussion and expresses the opinion that the "running out" of potatoes is due to environment and not to virus diseases.

Panaschierung und Mosaikkrankheit. (Variegation and the mosaic disease.) Forsch. Gebiet Pflanzenkr. u. Immunitat in Pflanzenreich 1(4) : 16-22, 1927.

The author criticizes the classification of Küster and Sorauer. $\mathrm{He}$ claims that variegations are transmitted through the germ plasm; that mosaic diseases have symptoms other than mottling.

\section{$\therefore$., \& Weber, H[ermann]}

Über das Vorkommen von intrezellularen Körpern in den Geweben mosaikkranker Rüben. (Occurrence of intracellular bodies in the tissues of mosaic-diseased beets.) Forsch. Gebiet Pflanzenkr. u. Immunitat Pflanzer. 1(4) : 23-42, 1927.

The author describes intracellular bodies found in the phloem of mosaic beets. These bodies were not found in healthy beets.

Ueber die wechselseitize ueber tragbarkeit des Mosaikkrankheit von Rübe und Spinat. (On the intertransmissibility of t'ee mosaic, disease of beet and spinach.) Centrabl. Für Bakt. Abt. II, 71:490-497, 1927. (Rev. Appl. Mycol. $7: 136,1927$.

The disease of these two plants are the same or closely related. They are transmitted by Aphis fabae (A. rumicis) and Macrosiphum.

Der gegewartige Stand der Forschung über Viruskrankheit. (Present status of research on virus diseases.) Beiträge $\mathrm{z}$. Pflanzenzucht. 9: 25-41, 1927, (Pflanzenbau 4: 9-10, 1927-28.) 
\& Lüdtke, IM.

Untersuchungen über Viruskrankheiten. 9. Beiträge zur kenntnis des stoffwechsels mosaikkranker und gesunder Tabakpflanzen. (Investigations about the virus diseases. 9. Contribution to the study of assimilation in mosaic diseased and healthy tobaceo plants.) Phytopath. Zeitschr. 2:341-359, 1930.

On the differentiation and transmission of virus diseases of the Solanaceae and the dependence of their occurrence and spread on the nutrition of the plants. Fifth Intern. Bot. Congr. Cambridge 1930 : 380-382, 1930.

\section{\& IVIuller, W.}

Untersuchugen über Viruskrankheit (10 Mitteilung). Wechselseitge Virusü-ber-tragungen innerhalb des Famile der Solanaceen. (Investigations on virus diseases (Note 10). Reciprocal virus transmission within the family of the Solanaceae.) Phytopath. Zeitschr. 3(2): 105-136, 1931.

A very extensive and detailed discussion on the subject.

\section{\& Johnssen, A.}

Untersuchungen über Viruskrankheiten (II Mitteilung). Beiträge zur kenntnis der Blattrollkrankheit der Kartoffel. (Studies on virus diseases. (Note II). Contributions to the knowledge of the potato leaf-roll disease.) Phytopath. Zeitschr. 5(6) : 603-612, 1933.

The author describes the successful results obtained in his experiments in the transmission of leaf roll disease by means of the aphids Myzus persicae and by grafting.

Schander, $R$ [ichard]

(Potato diseases.) Fuhling's Landw. Ztg. 58(8) : 273-285, 1909.

(New studies on the leaf-roll disease of the potato.) Jahresber ver. Angew Bot. 7:235-245, 1909.

(The leaf-roll disease of the potato.). Ber. West Preuss. Bot. Zool. ver. 32: 70-72, 1910.

(Leaf-roll of potatoes and related diseases.) Fuhling's Landw. Ztg. 63(7) : 225-243, 1914.

\section{\& Tiesenhausen, M[anfred]}

Kann maw die Phloemnecrose als Ursache oder Symptom der Blattroll Krankheit der Kartoffel ansehen. (Phloem necrosis 
as cause or symptom of leaf-roll of potato.) Mitt Kaiser Wilhelms Inst. Landw. Bromberg 6(2) : 115-124, 1914.

\section{\& Richter, $\mathbf{K}[\operatorname{arl}]$}

Untersuchugen über das Verhältnis der keimfähigheit der Kartoffelknollen zum Gesundheitszustand und Ertrag. (Investigations on the relations of the germination activity of potato tubers to healthiness and yield.) Centralbl. für Bakt., Abt. $2,60(1-6): 27-80,1923$.

Zur Mosaikkrankheit der Kartoffel. (Mosaic disease of potato.)

D. Kartoffel 5:212-213, 1925.

Neuere Arbeiten über die Blattrollkrankheit. (New work on the potato leaf-roll.) Mitt. der D. L. G. 42(23) : 613-615, 1927.

Physiologische Untersuchungen an Blattrollkrankheiten Kartoffel. (Physiological investigation on potato leaf-roll disease.) Landw. Versuchs-Stationnen 55(3-4) : 198-204, 1927.

\section{\& Bielert}

Nekrose und andere Degeneration serscheinungen im Phloem der Kartoffelpflanzen. (Necrosis and other degeneration phenomena in the phloem of potato plants.) Arb. Biol. Reichsanst. Land u. Fortwirtsch. 15(5) : 609-672, 1928.

The author discusses necrosis which is a pathological condition; and necrobiosis and obliteration which are due to old age.

Schek, A.

Ueber de Kräuselkheit der Kartoffeln. (On the curl disease of potatoes.) D. Landw. Presse 2:666, 1875.

Historical.

\section{Scherffius, W[illiam] H[enry]}

Tobacco mosaic. Some interesting experiments on a supposed disease in Turkish tobaceo. Journ. Dept. Agric. South Africa, 8(1) : 33-34, 1924.

The author claims that certain green splotehes in cured tobacco are , not caused primarily by mosaic.

\section{Schertz, F[rank] $\mathbf{M}[$ ilton]}

A chemical and physiological study of mottling of leaves. Bot. Gaz. 71: 81-130, 1921.

This is not a study on virus diseases, but is of interest to students of the subject. 


\section{Schewe, 0.}

Der einfluss der kalidüngung auf die Blattrollkrankheit der kartoffel. (The influence of potash fertilization on the leafroll disease of potato.) Ernahr. d. Pflanze 19:121-122, 1923.

\section{Schleh}

Ein Beitrag zur Kenntnis der Blattrollkrankheit der .Kartoffeln (A contribution to the study of the leaf roll disease of potatoes.) Fühlings Land. Zeit. 58:641-663, 1909.

\section{Schlumger, $\mathrm{O}[\mathrm{tto}]$}

Beobachtungen und Erfahrungen über den Gesundheitszustand der Kartoffel in Fahre 1930. (Observations and experiences in connection with the state of health of potatoes in the year 1930.) Pflanzenbau 7(4) : 118-119, 1930.

Roguing is recommended by the author to prevent spread of mosaic in the field from plant to plant.

Schmid, A.

Zur Vererbung der Blattrollkrankheit der kartoffel. (Inheritance of leaf-roll disease of potatoes.) Illus. Landw. Ztg., 31 (17) : 160, 1911. (Abs. Centbl. Bat. Abt. 31:331-332, 1911.)

Schmidt, A.

Die Kräuselkrankheit der Pelargonien. (The curl disease of Pelargonium.) Gärtner-Börse 13:1-308, 1931.

\section{Schmidt, E[rnst] W[illy]}

(A discussion of the leaf-roll disease of the potato.) Dent. Landw. Presse. 36(99) : 1051, 1909.

Zur Mosaikkrankheit der Zuckerrübe. (Mosaic disease of sugar beet.) Ber. Deutsch. Bot. Ges. 45(9) : 598-601, 1927.

A discussion of the significance of crystals in the roots of mosaic beets.

Zur Mossaikkrankheit der Zucker-und Futterübe. (Mosaic disease of sugar and fodder beets.) Deut. Zuckerid. 52:13051306, 1927.

The author reports a mosaic disease of sugar beet in Germany.

\section{Scholz, W.}

Bisherige forschungsergebuiss betreffend die chlorose der gelben lupina (Lupinus luteus) in ibren beziechung zum eizen. (Vorlanfige voroffenlichung.) (Results so far obtained from researches connected with chlorosis of the yellow Lupin (Lupinus 
luteus) in its relation to iron. (Preliminary publication.) Zeitschr. fur Pflanzen. Dungung \& Bodenkunde. A. 25: 287293, 1932.

A summarization of previous work and its announcement of work in progress.

\section{Schribane}

Recherches sur l' enroulement de fescilles de la Pomme de terre. (Researches on the leaf-roll of potato.) Comptes Rendus Acad. Agr. France 5(10) : 356-358, 1919.

\section{Schribau, Emile}

Sur la dégénérescence des pommes de terre. (Potato degeneration.) Acad. Ag. France Compt. Rend. 8: 397-398, 1922.

Sur la dégénérescence de la pomme de terre et sur les moyens de la conjurer. (The degeneration of the potato and the means of preventing it.) Comp. Rendus. Acad. Agr. de France, 9 (3) : 95-97, 1923.

\section{Schultz, E[dwin] W[illiam]}

The ultrascopic viruses from the biological standpoint. Sci. Mo. $31: 422-443$, Nov. 1930.

A general discussion dealing mostly with virus diseases of animals.

Schultz, Eugene S[chultz], Folsom, D[onald], Hildebrandt, F[rank] IM[errill], \& Hawkins, L[on] A[drian]

Investigations on the mosaic disease of the Irish potato. Journ. Agr. Res. 17(6) : 247-273, 1919.

This paper gives a discussion of distribution, losses, symptoms and methods of transmission. The disease can be transmitted in tubers, by grafting and by Myzus persicae and Macrosiphum solanifolii. The leaves from diseased plants contain more sugar and less starch than the leaves from healthy plants. Tubers from diseased plants may produce plants without symptoms. Hill selection does not give satisfactory results. Roguing before the coming of the insect vectors is efficient.

\&

Transmission of the mosaic disease of Irish potatoes. Journ. Agr. Res. 19(7) : 315-338, 1920.

Gives results of experiments showing that the disease can be transmitted by tubers, grafting, plant juice and aphids.

A transmissible mosaic disease of Chinese cabbage, mustard and turnips. Journ. of Agric. Res. 22(3) : 173-179, 1921.

Symptoms and transmission experiments. 


\section{\& Folsom D[onald]}

Leaf-roll, net-necrosis, and spindling-sprout of the Irish potato. Journ. Agr. Res. 21(1) : 47-80, 1921.

Gives the results of studies, mostly on transmission which is by aphids.

$$
\&
$$

Transmission of potato streak. Phytopathology (Abstract) 12 (1) : 41, 1922 .

$$
\text { ., \& }
$$

A spindling-tuber disease of Irish potatoes. Science n. s. 57: 149, 1923.

Proofs by transmission that this is a virus disease.

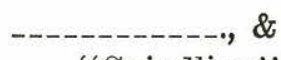

"Spindling" tuber and other degeneration diseases of Irish potatoes. Phytopathology (Abstract) 13(1): 40, 1923.

, \&

Transmission, variation and control of certain degeneration diseases of Irish potatoes. Journ. Agr. Res. 25(2) : 43-118, 1923.

Gives the results of extensive studies of the virus diseases of potatoes with special attention to their transmission from diseased to healthy plants and methods of control.

Why potatoes run out. U.S. D. Agr. Farmers' Bull. 1436, 21 p., 1924.

A popular discussion.

\section{\& Folsom, Donald}

Infection and dissemination experiments with degeneration diseases of potatoes. Observations in 1923. Journ. Agr. Res. $30(6)$ : 493-528, 1925.

A description of symptoms including second generation reactions. Also extensive experiments on methods of transmission.

A potato necrosis resulting from cross-inoculation between apparently healthy potato plants. Science n.s. 62(1616):571572,1925 .

The content of this paper is indicated by the title. The author thinks that the apparently healthy potatoes may have been symptomless carriers.

Potato diseases. Potato Assoc. Amer. Proc. 15: 293-296, 1928. Popular. 


\section{\& Bonde, Reiner}

Apical leaf-roll of potato. Phytopathology (Abstract) 19(1) : 82, 83, 1929.

\section{\& Folsom, Donald}

Recent potato virus-disease information contributing to the production of better seed potatoes. Proc. Ann. Meeting Potato Assoc. Amer. 15:203-226, 1929. (Maine Agric. Expt. Sta. Bull. $353: 147$, 1929.)

A popular discussion.

Potato virus diseases. Proc. Ann. Meeting Potato Assoc. Amer. 15 : 293-295, 1929.

A popular discussion.

\section{\& Raleigh, W[alter] $\mathbf{P}$.}

Resistance of potato to latent mosaic. Phytopathology (Abstract) 23(1):32, 1933 .

Report of results obtained with inoculations of latent mosaic which is generally present in a masked form in Green Mountain and other potato varieties.

New necrotic virus disease of potatoes. Phytopathology (Abstract) 23(1):32, 1933.

Comparisons of this new virus disease with other types. Transferable to tomato, tobacco and Datura stramonium.

Bonde, Reiner, \& Raleigh, W. P.

Components of potato mild mosaic. Phytopathology (Abstract) 24(1) : 17, 1934.

Stevenson, F. J.

Clark, C. F., Bonde, Reiner, Raleigh, W. P., \&

Resistance of potato to mosaic and other virus diseases. Phytopathology 24(2):116-132, 1934.

A thorough account of the authors based on experimental observations on varietal resistance.

Schultz, G.

Entartung der Magnum bonum-Kartoffel? Deut. Landw. Presse 32 : 872-875, 1905.

\section{Schwartz, M[arie] B[eatrice]}

Eenige ziekten van onbekenden sard bij groenhemesters. (English Summary.) Inst. Plantenziekten. Korte. Meded. 5, 19 p., 1927. 


\section{Schwarze, Carl Aloise}

Relation of the mosaic of the pepper and the filiform leaf of the tomato to the mosaic of the tobacco. Phytopathology (Abstract) $4(1): 42,1914$.

\section{Schweiner, J.}

Over virusziekten bij tabak. (On the virus diseases of tobacco.)

Verlag Negende Vergadering V.V.P.P. p. 81, 1928.

\section{Schweizer, G[eorge]}

Zur Blattrollkrankheit der Kartoffelpflanze. (Leaf-roll disease of the potato plant.) Ber. Deutsch. Bot. Ges. 44(9):551561, 1926.

Physiological and chemical studies which show that there was more diastase in diseased than in healthy plants.

Ein Beitrag zur Atiologie und Therapie der Blattrollkrankheit bei der kartoffelplanze. (A contribution to the etiology and cure of the leaf-roll disease of the potato plant. Phytopath. Zeitschr. 2(6) : 557-591, 1930.

An extensive discussion on the etiology studies made by the author, giving as a promising controll method, the application to the soil of a mixture of manganese, lime, cyamide and uranium salts.

\section{Schwing, E[dward] A., \& Hartung W[illiam] J[ohn]}

Utilization of systematic observations on beet leafhopper ( $E t_{i-}$ tettix tenella Baker) and curly leaf of sugar beet. Journ. Econ. Ent. 15(5) : 365-368, 1922.

Notes on Euttetix tenella (Baker) in Northern California. Journ. Econ. Ent. 20:645-646, 1927.

A record of the overwintering of the insect.

Experiments on control of Eutettix tenellus (Baker). Journ. Econ. Ent. 27: 790-791, 1928.

A brief paper giving methods and results.

\section{Sein, Jr., F[rancisco $]$}

Sugar-cane mosaic and other grasses. Ins. Expt. Sta. Report of the Div. of Entomology, Puerto Rico, Rpt. 1923-24: 114, 1924.

Report of experiments in progress in relation to mosaic transmission using different aphid species.

A new mechanical method for artificially transmitting sugarcane mosaic. Journ. Dept. Agric. Puerto Rico 14(2):49-68, 1930 . 
The author deseribes a new method in which he uses very fine insect pins. The spindle of a diseased plant is removed and placed in close contact with the spindle of a healthy plant. The pins are pushed through the diseased and into the healthy plant. The author reports a high percentage of infection.

Artificial transmission and other studies on sugar-cane mosaic. Fourth Cong. Internt. Soc. Sugar-Cane Technologists, Puerto Rico, 1932, Bull. 84, 6 p., 1933.

The author discusses the subject under widely different points of view. Some of them towards the nature of the virus and others dealing with its mechanical and insect transmission. Aphis maidis is conclusively a carrier of the disease; Sipha flava Forbes is not.

\section{Selby, A[ugustine] D[awson]}

Peach yellows, black rot and San José scale. Ohio Expt. Sta. Bull. 72:193-220, 1896.

A brief discussion of symptoms, cause, spread and treatment.

Investigations of plant disease in the foreing house and garden. Ohio Agric. Expt. Sta. Bull. 73:221-246, 1896.

Preliminary report on diseases of the peach. 1.-peach yellows. Ohio Agric. Expt. Sta. Bull. 92:190-199, 1898.

Report of committee on vegetable pathology. A peculiar malady of forced cucumbers. Ohio State Hort. Soc. Ann. Rept. 1902 : 109, 1903.

Popular. Early record.

Tobaceo diseases and tobaceo breeding. Ohio Agric. Expt. Sta. Bull. 156: 88-94, 1904.

Deseribes diseases and reviews work of others. Proves transmission by touching diseased and then healthy plants. Gives percentages of transmission by this method. Not transmitted by the seed.

Mosaie disease of cucumber. Ohio Agric. Expt. Sta. Bull. 214: 394, 1910.

Early record of this disease. The author believes it was due to an oxidizing ferment in the leaves. Compares it with tobacco mosaic and peach yellows.

\section{Semple, D[avid] IM[c Hardy]}

Mosaic diseases cause heavy losses. Sugar Centr. \& Planters'

News, Philippines. 4:140, 1923.

Popular. Estimation of losses. 


\section{Serrano, F[elicisimo] B.}

Banana diseases in the Philippines. Bureau of Agric. Philippine Is. Circ. 176, 1925. (Philippine Agric. Rev. 18(4) : 578$582,1925$.

Brief discussion of bunchy top disease on page 58 .

\section{Soubert, Elisabeth}

Uber Keimschadigungen der Erstling durch Virus-Netnekrose. D. Kartoffel 7:131-132, 1927.

\section{Severin, H[enry] H[erman] P[aul]}

Investigations of the beet leafhopper Eutettix tenella (Baker). Journ. Econ. Ent. 12: 312-326, 1919.

The author discusses the hibernation of the insect and the plants from which it carries the curly top to the beets. Gives the results of experiments with the insect and list of host plants for the virus.

The beet leaf-hopper. A report on investigations into its occurrence in California. Facts About Sugar 8(7):130, 131, 134. (8) : 150, 151. (9):170, 171, $173 . \quad$ (10): 190, 191. (11) : 210, $211 . \quad(12): 230,231 . \quad(13): 250,255,1919$.

Minimum incubation periods of causative agent of curly-leaf in beet leaf-hopper and sugar-beet. Phytopathology 11(10): 424-429, 1921.

Experiment with a dusting machine to control the beet leafhopper Eutettix tenella (Baker) with nicotine dust. Journ. Econ. Ent. 14: 405-410, 1921.

Practical use of curly leaf symptoms. Facts About Sugar 12: 170-173, 212-214, 217, 1921.

Popular.

Minimum incubation period of causative agent of curly leaf in beet leaf hopper (Eutettix tenella, Baker) and sugar beet. Phytopathology (Abstract) 12:105, 1922.

Curly-top transmission experiments with beet leaf-hopper. Journ. Econ. Ent. 15 : 182, 1922.

The author gives evidence that incubation of the active agent is necessary. He says - "The minimum incubation period of the infective principle of curly leaf in the beet leafhopper required four hours at the following temperatures: maximum $103^{\circ} \mathrm{F}$; minimum 
$94^{\circ} \mathrm{F}$. and mean $100^{\circ} \mathrm{F}$. and three days in the sugar beet at the following temperatures: maximum $100^{\circ} \mathrm{F}$., minimum $57.7^{\circ}$ and mean $80.3^{\circ}$ F."

\section{\& Basinger, A. J.}

Facts concerning migration of beet leaf-hopper Eutettix tenella (Baker) in Sacramento Valley of California. Journ. Econ. Ent. 15 : 404 411, 1922.

This paper is important because the insect is the carrier of the virus of the curly top of the sugar beet.

Facts concerning natural breeding area of beet leaf-hopper $F u$ tettix tenella (Baker) in San Joaquín Valley of California. Journ. Econ. Ent. 15: 411-420, 1922.

This paper is important because the insect is the carrier of the curly-top of the sugar beet.

Control of the Leaf-hopper. Facts About Sugar 14:312-313, 332-333, 1922.

The author gives suggestions for the control of the insects.

The life history of the beet leafhopper. Facts About Sugar 14: 92-93, 119-121, 130-131, 152-154, 158, 170-171, 1922.

Life history.

Control of the beet leafhopper. Facts About Sugar 15:134135, 137.1922.

The insects were checked by dusting with nicotine compounds and the amount of curly top reduced.

\section{Hartung, W[illiam] J[ohn], Schwing E[dward], A.,}

\& Thomas, W[illiam W.]

Investigations of beet leafhopper Eutettix tenella (Baker) in Salinas Valley of California. Journ. Econ. Ent. 16(6) : 479485, 1923.

Incubation period. California Agric. Expt. Sta. Ann. Rept. 1922-23 : 127, 1923.

Curly leaf transmission experiments. Phytopathology (Abstract) $14(2): 123,1924$.

Curly leaf transmission experiments. Phytopathology 14(2) : 80-93, 1924. 
334 THE JOURNAL OF AGRICULTURE OF THE UNIVERSITY OF P. $\mathrm{R}$.

A small amount of injections resulted from putting small drops of juice on leaves. The disease is earried by leaf hoppers. The active agent travels about 7 inches in about 30 minutes at a temperature of 103.5 degrees $\mathrm{F}$.

Causes of fluctuation in number of beet leafhoppers Eutettix tenella (Baker) in a natural breeding area of the San Joaquín Valley in California. Journ. Eeon. Ent. 17:639-645, 1924.

This paper is important because the insect is the carrier' of the virus causing the curly top of the sugar beet.

A natural breeding area of the beet leaf hopper (Eutettix tenella, Baker.) in the Sierra Nevada mountains. Journal Econ. Ent. 18(5) : 730-733, 1925.

Percentage of curly-top infection in beet leafhopper Eutettix tenella (Baker) and winter host plants under field conditions. Journ. Econ. Ent. 18(5) : 733-737, 1925.

A record which is of importance in connection with the study of the curly top of sugar beets.

The 1925 outbreak of the beet leafhopper Eutettix tenella (Baker) in California. Journ. Econ. Ent. 19:478-483, 1926.

Crops naturally infected with sugar beet curly-top. Science n. s. 66(1701) : 137-138, 1927.

This is a brief paper giving a list of crops naturally infected with the curly top.

Notes on curly-top. Facts About Sugar. 22(35): 844, 1927.

As a result of inoculation experiments the author gives a lengthy list of susceptible plants.

\section{\& Severin, Harry C [harles]}

Curly-top of sugar beets in South Dakota. Journ. Econ. Ent. $20(4): 586-588,1927$.

A report of the occurrence of the disease at this place. The insect vectors could not be found.

\section{\& Henderson, C[harles] F.}

Beet leafhopper Eutettix Tenellus (Baker) does not oceur in the Argentine Republic. Journ. Econ. Ent. 21:542-544, 1928.

A history of the records and claims. 
Some host plants of curly-top. Hilgardia 3(13) : 339-392, 1928. The authors discuss the flights of the leaf hoppers, give symptoms and valuable lists of host plants.

\section{\& Swezy, Olive}

Filtration experiments on curly top of sugar beets. Phytopathology 18(8): 681-690, 1928.

The author gives the results of feeding the leafhopper on filtered virus. These insects were able to transmit the disease but the juice became inactive on exposure to air.

Transmission of tomato yellows, or curly top of the sugar beet by Eutettix tenellus (Baker) Hilgardia 3(10): 251-274, 1928. (Phytopathology 18:709-710, 1928.)

The author discusses the nature of the injury, symptomatology, life history of the insect earrier, inoculation experiments and some economic features of the disease.

Curly top symptoms on the sugar beet. California Agric. Expt. Sta. Bull. 465, 35 p., 1929.

A very thorough and well illustrated paper on symptoms.

Yellows disease of eelery, lettuce, and other plants. transmitted by Cicadula sexnotatc (Fall). Hilgardia 3(18):543-582, 1929.

The disease is transmitted by Cicadula sexnotata (Fall). It is identical with aster yellows and with lettuce yellows. The disease also attacks several other plants.

Additional host plants of curly top. Hilgardia 3(20):595636, 1929.

The author gives records concerning newly diseovered earriers of the virus of curly top.

Carrot and parsley yellows transmitted by the six-spotted leafhopper, Cicadulla sexnotata (Fall). Phytopathology 20(11) : 920-921, 1930.

Parsley and earrots were successfully reciprocally and cross-inoculated.

Modes of curly top transmission by the beet leaf-hopper, ( $E$ utettix tenellus (Baker). Higardia 6(8) : 253-276, 1931.

The author gives much valuable data. The disease has been transmitted by 40 insects in as short a time as 20 minutes. The author 
gives the results of extensive experimental work on this subject. The percentage of infected plants varied with the time the insects were allowed to feed on the plant and the number of insects used. The author gives tables and an excellent summary of the work.

Transmission of carrot, parsley and parsnip yellows by Ciccodulla divisa. Hilgardia 7(3):163-179, 1932

The author gives the symptoms, the disease and the results of experiments. The disease was transmitted back and forth among these three hosts and from the hosts to asters, celery and dock.

\section{\& Freitag, Julius $\mathbf{H}$.}

Some properties of the curly-top virus. Hilgardia 8(1):1-18, 1933.

Results of studies made by the author in regard to curly-top virus, its properties, nature, inactivation, physical properties and other valuable data.

Field observations on the beet leafhopper Eutettix tenellus (Baker) in California. Hilgaria 7:281-350, 1933.

This paper gives a large amount of data concerning this insect which is the carrier of the curly top of the sugar beet.

\section{\& Freitag, Julius $\mathrm{H}$.}

List of ornamental flowering plants naturally infected with curly top or yellows diseases in California. U.S.D.A. Plant Disease Reporter 17(1):1-2, 1933.

\section{Shaposhnikov, J. J.}

(Russian beet variety resistant to curly top.) Sovietskü Sakhar. 1929:570-571, 1929; (Facts About Sugar (Abstracts) 25(9) : 216, 1930; Rev. Appl. Mycol. 9:425, 1930.)

The seed of variety $\mathrm{P}-19$, which was produced in California was sent to its original home in Ivanovka, Russia. The seed from this crop was returned to California and grown. It was found to be resistant to curly top but the sugar content was less than the checks. The loss in sugar content was compensated by the resistance to the disease.

\section{Shapovalov, IM[ichael]}

Effect of environmental conditions on western yellow blight of tomatoes. Phytopathology (Abstract) 14(2): 120, 1924.

The significance of the 1924 outbreak of western yellow tomato blight in the United States. Phytopathology (Abstract) 15: 50,1925 . 
High evaporation: a precusor and a concomitant of western yellow blight. Phytopathology 15:220-278; 470-478, 1925.

A study of the relationship of environmental factors to the development of this disease.

Ecological aspects of a pathological problem (Western yellow blight of tomatoes.) Ecology 6:241-259, 1925.

\section{\& Beecher, F. Sidney}

Menace of western yellow tomato blight. Pacific Rural Press. $111: 365-371,1926$.

The A.A.A.S. The Reno meeting of the Pacific division 11 American Phytopathological Society. Pacific Division. Science (Abstract) 66:247, 1927.

Inoculation experiments with western yellow tomato blight in relation to environmental conditions. Phytopathology (Abstract) $17(10): 746,1927$.

Yellows, a serious disease of tomatoes. U.S.D.A. Misc. Pub. $13: 2-4,1928$.

A brief review of our knowledge of the subject.

\section{\& Beecher, F. Sidney}

The development of tomato yellows under different light conditions. Phytopathology (Abstract) 18(11):950, 1928.

Tuber transmission of psyllid yellows in California. Phytopathology (Abstract) 19(12):1140, 1929.

\section{\& Beecher, F. Sidney}

Experiments on the control of tomato yellows. U.S.D.A. Tech. Bull. 189, 1930.

The virus of this disease is the same as the virus of curly top of sugar beets and is carried by the leafhopper Eutettix tenellus Baker. The authors review the subject and give the results of experimental work. The disease is reduced by shading but dusting and spraying for the control of the insects gave encouraging results.

A celluloid cell for inoculation of plants with insect vectors. Phytopathology 20(8) : 681-683, 1930.

Illustration and description of this apparatus is of interest to students of inoculation of plant viruses. 


\section{\& Jones, Henry A.}

Changes in the composition of the tomato plant accompanying different stages of yellows. Plant Physiol. 5(1):157-165, 1930.

The authors report the following ehanges:

1.-The increase of dry matter and the accumulation of starch and sugars appeared to be constant and should be regarded as a condition characteristic of this virus disease.

2.-Changes in the amount of nitrogen is variable.

3.-The carbohydrate accumulation in the same plant is progressive. Other valuable data is given.

\section{\& Lesley, J[ames] W[yvill]}

Effect of shading on the rate of development of tomato yellows. Phytopathology 21(1) : 83-87, 1931.

Shading increases the tolerance of the plant to the virus provided that partial protection from beet leafhopper (Eutettix tenella Baker) is afforded. If continued after infection a crop is produced and in some cases recovery from the disease occurs.

The growth rate of tomato plants affected by yellows. Phytopathology (Abstract) 21(1): 106, 1931.

Graft transmission of eurly top in tomatoes (tomato yellows). Phytopathology (Abstract) 21(10): 998-999, 1931.

The dieback form of tomato streak. Phytopathology (Abstract) 23(11) : 928, 1933.

\section{Shaw, Harry B[erry]}

The curly top of beets. U.S.D.A. Br. Plant. Indus. Bull 181, 46 p., 1910.

Describes the symptoms and gives the results of experiments to determine the cause. Also discusses the leafhopper Eutettix tenella (Baker) in relation to the disease and to some of its other host plants.

\section{Shear, C[ornelius] L[ott]}

Cranberry diseases in Wisconsin. Wisconsin State Cranberry Growers' Assoc. Ann. Rept. 21:17-21, 1908.

Early record.

False blossom of the cultivated cranberry. U.S.D.A. Bull. 444, 1916.

A general discussion of the disease, the eause of which was unknown at that time. 


\section{Shear, W[illiam] V.}

How certified seed potatoes will benefit the California potato industry. Calif. Dept. of Agric. Monthly Bull. 9(9):375391. 1920.

\section{Sheffield, F[rances] MIarion] L[ena], \& Smith, J[ohn] H[enderson]}

Intracellular bodies in plant virus diseases. Nature 125(3141): 200, 1930.

The authors give the results of their studies on the $\mathrm{x}$-bodies in the living epidermal hairs of Solanum nodiflorum.

The formation of intracellular inclusions in Solonaceous hosts infected with aucuba mosaic of tomato. Ann. Appl. Biol. $18(4): 471-493,1931$.

These bodies were formed by inoculating aucuba mosaic into Solanum nigrum, S. nodiflorum, S. Lycopersicum, Nicotiana tabacum and Hyoscyamus niger. The author describes the formation of these bodies.

The development of assimilatory tissue in solanaceous hosts infected with aucuba mosaic of tomato, Ann. App. Biol. 20 (1) : 57-69, 1933.

The author describes the development of the chloroplast in Solanum nodiflorum, S. Lycopersicum and Nicotiana tabacum and compares healthy and diseased plants. In plants infected with aucuba mosaic certain of the leaf tissues are devoid of plastids and the cells may be undifferentiated. The absence of chlorophyll is brought about by the inhibition by the virus of the development of the plastid primordia.

Virus diseases and intracellular inclusion in plants. Nature $131(3305)$ : 325-326, 1933.

Description of experiments conducted to determine whether reactions in certain Solanaceae similar to those induced by inoculation with aucuba mosaic of tomato could be stimulated by physico-chemical means. The plants treated were tomato, Solanum nigrum and $S$. nodiflorum.

\section{Shepard, E[dward] F[rederick] S[isnett]}

Les maladies Mosaïques des plantes. (Mosaic disease of plants.) Rev. Agric. Ile Maurice 12:332-335, 1923.

(Summarized report on the position in relation to sugar-cane Mosaic in Reunion.) Rev. Agr. de L'Ile Maurice 13:59 61, 1924. (Rev. Appl. Mycol. 4:313, 1924 Maurice Dept. Agric. 3 p. 1924.) 
Considerations sur la presence de la mosaïque á la Reunion. (Considerations about the presence of mosaic in Reunion.) La Rev. Agric. de L'Ile Maurice 19:384-389, 1925.

Mosaic disease serious in Reunion, Is. South African Sugar Journ. 9: 97, 99, 101, 1925.

The author gives a general discussion of mosaic diseases with special reference to conditions in Reunion Island.

Les "streak disease" des gramines á Maurice, Is. (The "streak disease", of graminae in Mauritius, Is.) Rev. Agr. Ile Reunion. 11(3) : 352-357, 1925. (Rev. Agric. Ile Maurice, 22 : $540-542,1925$.

Maize chlorosis. Notes on chlorosis of Maize and other graminaceas in Mauritius, Is. Trop. Agric. (Trinidad) 6(11):330, 1929. (Rev. Applied Mycol. 9:300, 1930.)

A chlorosis of maize at first believed to be mosaic is now believed to be streak.

Mycological Division, Maurice Is. Dept. Agric. An. Rpt. 1928: 8-11, 1931.

Streak on maize and mosaic Physalis peruviana, cucurbits and Brassica sinensis is reported.

Diseases of sugar cane in Mauritius. Mauritius Dept. Agric. Bull. 41, Gen. Ser. 27 p., 1931.

A popular publication on diseases of sugar cane, containing some data on mosaic.

\section{Shevchenko, I. S.}

(Report on the mosaic-disease of the sugar beet at the phytopathological section of the kharkov Regional Agricultural Experiment Station for 1928-29.) In V. P. Muraviov. Mozaichnye Bolezni Sakharnoi Svekly (Mosaic diseases of sugar beet Kiev, S.S.U. Soiuzsakhara p. 67-98, 1930. (English Al)stract p. 97-98.)

Continuation of Proida's work, during 1928-29. Studies on transmission were undertaken. It was found that mosaic produces 1.1 per cent decrease in sugar content of the beet as maximum and 0.75 per cent as average and 12.9 per cent on beet seed output. No variety proves to be immune. It was found that the distance from the main source of infection is a factor as well as surface relief, wind direction and velocity. 


\section{Shevchenko, I. III.}

(The development of mosaic on the sugar beet in relation to the date of sowing.) In V. P. Muraviov, Mozạichnye. Boloezni Sakharnoi Svekly (Mosaic diseases of sugar beet) Kiev. S.S.U. Soiuzsakhara p. 167-176, 1930. (English Abstract p. 175-176.)

Comparable data of 1927 and 1928 sugar-beet crops. The second year crop showed decidedly more infection than the previous year.

Shevchenko, V. I.

(Injury which the mosaic produces on the sugar beet.) In V.P. Muraviov., Mozaichnye Bolezni Sakharnoi Svekly (Mosaic diseases of sugar beet). Kiev, S.S.U. Soiuzsakhara p. 161166, 1930. (English abstract p. 166.)

The author states, based on his observations during 1928 that no injury due to mosaic was recorded on beets. Weight of beets and sugar yields were observed and recorded on diseased plants, as well as seed produced.

\section{Shirreff, John}

On the curl disorder in potato. Caledonian Hort. Soc. Memoirs $1: 60-64,1914$.

Sieg, F. I.

Die Mosaik-krankheit der Gurken. (The mosaic disease of eucumber.) Gärtner Borse 10:363, 1928.

Sieger, F.

Ein Beitrag zur Erforschung der Kartoffelblattrollkrankheit. (A contribution to the investigations of potato leaf roll disease.) Zeitschr. Spiritusind. 31:415, 1908.

\section{Siemaszko, Wincenty}

Choroby drzew i krzewów owocoroych (Diseases of fruit trees and brush fruit.) Bibluoteka Oytawsja No. 6. Pulaway, 81, p. 3, 1930.

Supplement to diseases of cultivated plants, gives brief accounts of over 70 virus diseases occurring in Poland.

\section{Silberschmidt, $\mathbf{K}[\operatorname{arl}]$}

Der Einfluss der Mosaikkrankheit auf den Nikotingenhalt der Tabakpflanze. (The influence of the mosaic disease on the nicotine content of the tobaceo plant.) Ber. Deutsch. Bot. Gesellsch 48(1) : 122-129, 1930.

The writer gives details of his experiments to determine the relative nicotine contents of healthy and mosaic-diseased tobacco; diseased- 
plant leaves showed a higher nicotine content. He suggests that it is due to assimilation of albumen and the formation of nitrate and formaldehyde.

Studies zum Nachweis von Antikörpern in Pflanzen II. Teil B. (Beiträge zur Frage der Resistenz und Immunität von Pflanzen gegenüber dem in fizierenden Agens der Viruskrankheiten.) C. Studies in the detection of antibodies in plants. II Part B. (Contributions to the problem of resistance and immunity in plants in relation to the infective principle of the virus diseases.) Beitr. Biol. der Pflanzen, 20(2) : 105$178,1932$.

A very extensive and comprehensive account of the author's studies on the occurrence of antibodies in tobaceo plants conferring immunity from mosaic.

\section{Simmonds, J[ohn] H[oward]}

Spotted wilt of tomatoes. Queensland Agric. Journ. 28:28, 1927.

Bunchy top disease of bananas in Queensland. Queensland Agric. Journ. 30(4):438-442, 1928 . (Trop. Agric. (Ceylon) $72(3): 152-154,1929$.)

Bunchy top of the banana and its control. Queensland Agric. Journ. 41(3) : 241-244, 1934.

Brief article describing the disease, giving points concerning the nature and spread of it, and methods of control.

\section{Simonetto, MI[oisés ]}

Plan de investigaciones urgentes sobre las causas concomitantes de la plaga mosaico en la caña de azúcar. (Plan of urgent investigations about the symptomatic causes of the sugar cane mosaic disease.) Rev. Agric. Com. y Trab. Cuba 3 (9) : 351, 1920.

Nuevas orientaciones en sanidad vegetal. (New orientations about vegetable sanitation.) Rev. Agric. Com. y Trab. Cuba $3(9): 349-356,1920$.

Las Rayas Amarillas en la Caña de Azúcar. (Yellow stripes of Sugar Cane.) Cuba Azucarera. Sept. 15, p. 14, 1920. 
La enfermedad de las rayas amarillas en la caña: Su importancia y extensión en Cuba. (The yellow-stripe disease in Cane: Its importance and extension in Cuba.) Oficina de Sanidad Veg., Sec. Agric. Com. y Fábrica de Cuba. Bol. 3, 63 p., 1921.

The author gives a general discussion with recommendations for control.

La enfermedad de las rayas amarillas en la caña de azúcar. Réplica al Dr. S. C. Bruner. (The yellow stripe disease of sugar cane. Reply to Dr. S. C. Bruner.) Rev. Agric. Com. y Trab. Cuba 5(4) : 11-13, 44-48, 1922 . (Sugar 24:641-642, 1922.)

Controversial. A reply to Dr. S. C. Bruner.

Cómo se debe determinar con buena aproximación el porcentaje de cañas enfermas en un cañaveral infectado con el mosaico. (How to determine approximately the percentage of diseased canes in a cane field infested with the mosaic.) Rev. Agric. Com. y Trab. Cuba 5(3) :26-27, 1922.

\section{Simpson, J.}

The potato curl. Gard. Chron. N.S. 4:143, 1875.

Historical value.

\section{Sirotina, IM. (Mme.)}

(Cytological studies of sugar beet mosaic.) Sugar Ind. Scient. Notes Kieff, Grey ser. 9(24):195-216, 1932. (With English summary.)

A rather extensive account of the author's observations from her studies on the subject.

Skeete, C. C.

Sugar cane mosaic diseases. Barbados Dept. Agric. Ann. Rpt. 1927-28 : 15-16, 1928.

A brief report.

\section{Skinner, J[oshua] J[ohn], \& Demaree, J[uan] B[rewer]}

Relation of soil conditions and orchard management to the rosette of pecan trees. U.S.D.A. Bull. 1378, 16 p., 1926.

The increase of organie matter in the soil causes an increase in growth and yield. 


\section{Skoric, V[ladimir]}

Bolestibilja ne fakultetskom dobru "Maksomir" (Plant diseases at the University Farm "Maksimir".) Rapp. Ann. Univ. de Zagreb 1929: 723-746, 1930.

Bean and potato mosaic.

\section{Slosson, Edwin E[mery]}

Starting a new disease of the class called mosaic disease. Sci. Monthly 20 : 331-333, 1925. (Lit. Digest $85: 24,1925$.

Popular.

\section{Small, W[illiam]}

Bunchy-top disease of plantains in Ceylon. Trop. Agric. (Ceylon) 71(5) : 141-147, 1928.

The author doubts that this disease is due to a virus. He says that there is some evidence that it is caused by a fungus Rhizoctonia Bataticola.

\section{Smith, A. C.}

Virginia mountain grown seed potato demonstrations (Mosaic). Proc. Amer. Soc. Hort. Sci. p. 168-173, 1925.

\section{Smith, A. J. IVI.}

Bitter pit in Apples. A review of the problem. Dept. Sci. \& Indus. Res. Food Invest. Bd. Special Rpt. 28, 24 p., 1926.

Brief description of the characteristic symptoms, a critical review in some details of the theories on this disease, he admits the disease to be functional and not parasitic. This paper was written before the cause was known.

\section{Smith, C[harles] E[gan]}

Report on peach yellows. U.S.D.A. Comm. p. 393-398, 1889.

Notes on the Michigan diseases known as "little peach". Fennville Herald (Michigan) Oct. 15, 1898.

Transmission of cowpea mosaic by the bean leafbeetle. Science. $60(1551): 268,1924$.

Evidence indicates that the cowpea mosaic may be carried by the bean leaf-beetle Ceratoma trifurcata Forst.

\section{Smith, Erwin F[rink]}

Peach yellow. A preliminary report. U.S.D.A. Div. of Bot. Bull. 9, 254 p. 1888.

A very extensive publication giving the history of the disease, geographical distribution, characteristics, losses, relationships to climate and soils, methods of transmission and legislation. 
Additional evidence of peach yellows and peach rosette. U.S.D.A. Div. Veg. Path. Bull. 1, 65 p., 1891.

Describes these two diseases and gives the results of extensive experiments.

The chemistry of peach yellow I \& II. Proc. Ouner Pomol. Soc. 1889, 1891.

The peach rosette. Journ. Mycol. 6(4) : 143-148, 1891.

The disease is described. The author states that the beetles Scolytus regulosus does not transmit the disease. He also states that he observed the disease in cultivated plums and hard-shell almonds.

Peach yellows. Proc. Penninsular Hort. Soc. Jan. 22, 1891.

Experiments with fertilizer for the prevention and cure of Peach Yellows. U.S.D.A. Div. of Veg. Path. Bull. 4, 187 p. 1893.

Additional notes on peach rosette. Journ. Mycology 7:226232, 1893.

Additional data to that given in bulletin 1, Div. Veg. Pathology, U. S. Dept. Agric. p. 189. The disease was transmitted by budding. No organism has been found.

Peach yellows and peach rosette. U.S.D.A. Farmers' Bull. 17, 20 p., 1894.

A popular diseussion of the subject.

Notes on the Michigan disease known as "little peach," an address before the Saugatuck and Ganges pomological Society. 12 p. Reprinted from Fenville (Mich.) Herald, Oct. 15, 1898.

Popular.

Communicability of peach yellows and little peaches. U.S.D.A. Div of Veg. Path. 1:45-58, 1901.

The sereh disease of sugar cane. Bacteria in Relation to Plant Diseases 3: 72-80, 1914.

The author treats the disease from the standpoint of bacteriology. 
Smith, F. E. V.

Report of the Government Microbiologist. Ann. Rpt. Dept. of Agric. Jamaica 1927:18, 19, 1928. (Rev. Appl. Mycol. 7: 492, 1928.)

\section{Smith, F[anny] F[ern]}

Some cytological and physiological studies of mosaic diseases and leaf variations. Ann. Missouri Bot. Gard. 13(4) : 425484, 1926.

The author reviews the literature, gives the results of experiments. with light, the effects of chemicals on the inclusions, histological studies and variations in other plants.

\section{Smith, Floyd, T[ranking]}

The relation of insects to the transmission of raspberry leaf curl. Journ. Econ. Ent. 18(3) : 509-513, 1925.

The author reports the Aphis rubiphila as the carrier of raspberry leaf curl.

\section{Smith, J[ohn] Henderson}

Recent work on virus diseases in plants. Proc. Roy. Soc. Med. $20: 11-18,1927 . \quad$ (Rev. Appl. Mycol. (Abstract) 6: 501, 1927.)

Experiments with a mosaic disease of tomato. Ann. Appl. Biol. $15(2): 155-167,1928$.

A description and properties of a disease which is probably the same as Johnson's tobaceo virus 6 .

The transmission of potato mosaic to tomato. Ann. Appl. Biol. $15(4): 517-528,1928$.

This paper gives the results of transmission by mutilation of the foliage.

Virus diseases in plants. Translocation within the plant. II. The amoeboid intracellular inclusions. Biol. Rev. \& Biol. Proc. Cambridge Phil. Soc. 5(2) : 159-170, 1930.

The author states that we have little knowledge as to the mechanical routes for the spread of the virus. It probably travels from cell to. cell and into the water stream but mainly by the phloem. The author gives a full description of the $\mathrm{x}$-bodies which he believes are "a reaction product of the cell to the virus irritant."

Intracellular inclusion in mosaic of Solanum nodiflorum. Ann. Appl. Biol. $17(2)$ : 213-222, 1930. 
The author gives the results of inoculating Solanum nodiflorium with the virus of yellow (aueuba) mosaic of tomato. Two types of bodies were studied in the living cells, cristalline spikes and amoeboid bodies. The latter corresponds to the $\mathrm{x}$-bodies described by many students. The author describes them in detail and says no evidence in these investigations proves them to be organisms.

The differentiation and classification of plant viruses. Rpt. Proc. 5th, Inter. Bot. Congr. Cambridge p. 373-374, 1930.

Virus diseases of plants. In: System of Bact. i. Relat. Medic. London, Vol. 7:42-53, 1930.

A brief review of this subject.

Rothamsted Experiment Station Report for 1931:1-199, 1932. Studies on certain particles found associated with virus diseases.

Some aspects of virus diseases in plants. Empire Journ. Expt. Agric. 1(3) : 206-214, 1933.

A critical review of our present knowledge of this group of diseases. In conclusion he states: "Although much yet remains to be done both from fundamental and practical aspects, the virus problem is far from being a hopeless tangle."

Streak in tomatoes aseptically grown. Ann. Appl. Biol. 20 (1) : 117-122, 1933.

Two types of bacteria are found in tomato and tobaceo plants with streak disease. Experimental work does not show any relationship to the disease.

\section{Smith, Kenneth MIanley]}

Mosaic disease of plants. Nature 110:668, 1922.

A record of the finding of intra-cellular bodies in tissue of potato plants.

Some peculiar pathological conditions in the leaves of potatoes affected with mosaic diseases. Rept. Int. Conf. Phytopath. \& Econ. Ent. Holland, p. 30. H. Veenman \& Sons. Wageningen, 1923.

This paper gives the results of cytological studies on vacuolate bodies and nucleolar extensions in cells from chlorotic areas. 
348 THE JOURNAL OF AGRICULTURE OF THE UNIVERSITY OF P. $\mathrm{R}$.

On a curious effect of mosaic disease upon the cells of the potato leaf. Ann. Bot. 38(150) : 385-338, 1924.

A record of amoeba-like bodies closely associated with the nuclei.

A comparative study of the feeding methods of certain Hemiptera and the resulting effect on the plant tissue, with special reference to the potato plant. Ann. Appl. Biol. 13(1):109138, 1926.

A very interesting discussion, is included, of the relations of the facts elucidated in the study to the question of the transmission of the virus diseases of the potato by sucking insects.

Observations on some insect carriers of potato virus diseases. Mem. \& Proc. Manchester Lit. \& Philos. Soc. (Abstract) 71: 9-10, 1927.

Observations on the insect carriers of mosaic disease of the potato. Ann. Appl. Biol. 14(1) : 113-131, 1927.

A record of preliminary experiments with insect vectors and a list of insects that gave positive results.

A study of the feeding methods of certain sucking insects in relation to the spread of virus diseases of the potato by such insects. Mem. \& Proc. Manchester Lit. \& Philos. Soc. (Abstract) $70: 11-12,1927$.

Insects and potato virus diseases. Nature. 121(3058): 904, 1928.

The author passes the virus from a mosaic potato through tobacco and back to potato and produced intensified symptoms. The original virus could not be transmitted by Myzus persicae but modified virus was transmitted.

Insects in relation to potato virus diseases. Journ. Min. Agric. $37(3)$ : 302-344, 1929.

Studies on potato virus diseases. 4 Further experiments with potato mosaic. Ann. Appl. Biol. 16(1):1-13, 1929.

Positive proof of the transmission of potato mosaic by Myzus persicae. When potato mosaic virus was inoculated into healthy tobaceo it produced ring spot. It is difficult for $M$. persicae to transmit the virus back to potato. 
Studies on potato diseases. 5-Insect transmission of potato leaf roll. Ann. Appl. Biol. 16(2) : 209-229, 1929.

This is an extension of previous studies of this same subject.

Studies on potato virus diseases. 6-Further experiments with the virus of a potato mosaic upon the tobacco plant. Anu. Appl. Biol. 16(3) : 382-399, 1929. (Rev. Appl. Mycol. 9(2) : $124,133,1930$.

An interesting report on cross-inoculation of tobacco with potato mosaic, resulting in four types of ring spot.

Studies on potato virus diseases. 7-Some experiments with the virus of a potato crinkle with notes on interveinal mosaic. Ann. Appl. Biol. 17(2) : 223-240, 1930.

This paper contains records of the author's experimental work on transmission of several virus diseases of potato.

Insects in relation to potato virus disease. Journ. Min. Agr. (Gt. Britain) 37(3) : 224-232, 1930.

Popular.

Transmission of potato leafroll. Nature (London) 126(3168): 96, 1930.

On the composite nature of certain potato virus diseases of the mosaic group as revealed by the use of plant indicators, and selective methods of transmission. Proc. Roy. Soc. Bot. 109 (762) : 251-267, 1931.

The author describes the technique for the isolation of two viruses, $X$ and $Y$, from a symptomless streak carrying potato. $Y$ is liable to fluctuation in virulence, $X$ varies and causes several symptoms. The author believes that the different symptoms of various mosaic diseases are caused by strain of $\mathrm{X}$ rather than by different viruses.

Virus diseases of potatoes. Second Int. Cong. Path. Fac. Méd. Univ. Paris 2, 1931.

Thrips tabaci Lind. as a vector of plant virus disease. Nature $127(3214)$ : 852-853, 1931.

Reports that this insect ean transmit the virus of ring-spot to Solanum Capsicastrum, Datura and tobacco. Also the spotted wilt of tomato and a virus disease of Dahlia. 
Studies on potato virus diseases. 8-On a ring-spot virus affecting Solanaceous plants. Ann. Appl. Biol. 18(1) : 1-15, 1931.

Ring spot disease of the virus type of Solanum capsicastrum is first reported from the British Isle. Extensive discussion of solanaceous virus disease follows.

Studies on potato virus diseases. 9-Some further experiments on insect transmission of potato leaf-roll. Ann. Appl. Biol. 18(2) : 141-158, 1931.

Continuation of previous works by the author.

Composite nature of certain potato viruses of the mosaic group. Nature 127(3210): 702, 1931.

Natural and artificial manners of inoculation are discussed in regard to reaction on the plant to different types of mosaic.

Virus diseases of plants and their relationship with insect vectors. Biol. Rev. and Biol. Proc. Cambridge Phil. Soc. 6 (3) : 302-344, 1931.

A review of the subject with about 250 references in the bibliography. All known plant viruses are listed according to host plants and insect earrier given where known.

Filtration of plant viruses. Nature. 130(3276): 243, 1932.

Reports results similar to those carried on by MacClement and Henderson Smith. (Nature 130:129, 1932.)

Studies on plant virus diseases XI. Further experiments with a ring-spot virus: its identification with spotted wilt of tomato. Ann. Appl. Biol. 19(3) : 305-330, 1932.

A study of the English ring spot which is transmitted by Thrips tabaci. This disease which was first described from Solanum capsicastrum appears to be the same as the spotted wilt of Australia. It attacks a number of plants.

The present status of plant virus research. Biol. Rev. 8(2): 136179, 1933.

A very excellent review of our knowledge up to this time.

Spotted wilt: An important virus disease of the tomato. Journ. Min. Agric. 39(12) : 1097-1103, 1933.

Popular description and diseussion of the disease which is widely spread in England. 
Recent advances in the study of plant viruses. London, $423 \mathrm{p}$., 1933.

A book containing much valuable data.

Some virus diseases of the potato and other farm crops. Scottish Journ. Agric. 16(4): 446-456, 1933.

The author gives a comprehensive definition of a virus and a general review of present knowledge on the virus diseases of potatoes and other crops and their transmission by insects.

\section{Smith, L[oren] B[arlett]}

Spinach blight and its transmission by insects. Virginia State Ent. and Plant Path. Rpt. 11(1916-17) : 40-50, 1918. (Phytopathology (Abstract) 8(1):14, 1918.)

A review of the paper by McClintock and Smith (1918).

The life history and biology of the pink and green aphid (Macrosiphum solanifolii, Ashmead.) Virginia Truck Expt. Sta. Bull. 27 : 27-79, 1919.

Potato spraying experiments on the control of the pink and green aphid (Macrosiphum solanifolii, Ashmead.) Virginia Truck Expt. Sta. Bull. 29, pt. 1, p. 101-118, 1919.

Breeding mosaics resistant spinach and notes on malnutrition. Virginia Truck Expt. Sta. Bull. 31-32:137-160, 1920.

\section{Smith, R[alph] E[lliott]}

Growing China asters. Massachusetts Hatch Expt. Sta. Coll. Agric. Bull. 79, 26 p., 1902.

The author gave twelve pages to this diseases long before the cause was known.

Beet-blight investigations. California Agr. Expt. Sta. Bull. 184: 240-241, 1908.

\section{\& Smith E[lizabeth] $\mathrm{H}$ [ight]}

California plant diseases. Calif. Agric. Expt. Sta. Bull. 218: 1039-1193, 1911.

The investigation of "Physiological" plant diseases. Phytopathology 5(1) : 83-93, 1915.

This is a general paper which includes a brief discussion of virus diseases. 


\section{\& Boncquet, $\mathrm{P}$ [ierre] $\mathbf{A}$ [uguste]}

New light on curly top of the sugar beet. Phytopathology $5(2)$ : 103-107, 1915.

, \&

Connection of a bacterial organism with curly leaf of the sugar beet. Phytopathology 5(6) : 335-342, 1915.

The authors corroborate the findings concerning the relation of Eutettix tenella to this disease, give a brief discussion of the histology of the diseased plants and of a bacterium found in them.

The beet leafhopper and curly-leaf disease that it transmits. Phytopathology 8(4) : 168, 1918.

A complementary statement concerning Dr. E. D. Ball's Bulletin 155 of Utah Agrie. Expt. Sta., 1917, "The beet leafhopper and the Curly-leaf Disease that it Transmits."'

Smith, Roger C., \& Barker, H[enry] D.

Observations on the "yellow disease of beans and related plants in Haiti." Journ. Econ. Ent. 23(5) : 843-847, 1930.

The disease is either caused by a virus which is transmitted by a leafhopper (Empoasca sp.) or caused by the insect. It is not transmitted in the seeds.

\section{Smyth, E[ugene] Graywood}

Entomological Work. (The yellow stripe disease of sugar cane.) Report of the Com. of Agric. \& Labor of Puerto Rico. From Report of the Governor 1919:685-713, 1919.

Insects and mottling diseases. Journ. Dept. Agric. of Puerto Rico, 3(4) : 83-116, 1919. (Rev. Appl. Ent. Ser. A. 8:483, 1919.)

Gives a record of experiments conducted in an effort to determine the insect carriers of the disease. The results were negative.

List of the insects and mite pests of sugar eane in Puerto Rico. Journ. Dept. Agric. Puerto Rico. 3:135-150, 1919.

A paper prepared during the author's studies on insect transmigsion of the sugar-cane mosaic.

Report Division of Entomology. Ins. Expt. Sta. Puerto Rico Ann. Rpt. 1919-20 : 83-89, 1920. 


\section{Snell, K[arl]}

Panaschierung an Kartoffelblattern. (Variegations of potato leaves.) Nachrichtenbl. Deutsch. Pflanzenschutzd. 3 : 77, 1923.

\section{Snyder, William C.}

Pod deformation of mosaic-infected peas. Phytopathology 34 (1) : 78-80, 1934.

Review of Lindford's report made on a pea-disease in 1928 (U.S. D. A Br. Plant Indus. Suppl. 67, 1929.) Discussion of his observations.

Sokal, N.

Nouvelles recherches sur le virus filtrant de la pomme de terre. (New researches on potato filterable virus.) Comptes Rendus Soc. Biol. 103: 955-956, 1930.

\section{Sollewijn, G.}

Report over de serehziekte in het Cheribousche suikerriet. Indische Opmerker Maart 13, 1884.

Solovieva, IMme N. V.

(Observations on potato diseases in the Terek district in 19271928.) Bull. North Caucasian Plant. Prot. Stat. Rostoff on Don. 6-7: 85-94, 1930.

Potato degeneration diseases, chiefly leaf roll is reported from that district.

\section{Soltwedel, F.}

De serehziekte. Meded. Proefst. Midden-Java, Samarang, 1889.

\section{Sorauer, Paul C[arl Moritz]}

(Note at the end of some papers on a disease of sugar cane.)

Zeitschr. f. Pflanzenkrankheiten 1(6) : 360, 1891.

Die Augabliche Kartoffel-epidemic genennt die Blattrollkrankheit. International Phytopathologischer Dienst. 1: 33-59, 1908.

Die neueren Untersuchungen von Quanjer uber die Ursache der Sorauer'sche Standpunht. Zeitschrift fur Pflanzenkranheiten, Bd. 23(4) : 244-253, 1913.

Die Mosaikkrankheit des tabaks. (Mosaic disease of tobacco.) Handbuch der Pflanzenkrankheiten, 1: 678-683, 1909. 
354 THE JOURNAL OF AGRICULTURE OF THE UNIVERSITY OF P. R.

\section{Soriano, $\mathbf{S}$.}

El "corcovo" y el "polvillo" del tabaco en la República Argentina. (The "hunchback" and the "powdery" of tobacco in the Argentine Republic.) Argentina Rev. Fac. Agron. \& Vet. $7(2)$ : 371-392, 1931.

Account of these two diseases of occurrence in the Argentine Republic. The two diseases are fully described and the author concludes that "corcovo", and "polvillo' are varying manifestations of a single disease of the virus group. Both are decidedly infectious.

Notas sobre algunas enfermedades de los vegetales producidos por "virus" en la República Argentina. (Notes on some vegetables diseases caused by "virus" in the Argentine Republic.) Physis, Buenos Aires 11(38) : 87-90, 1932.

Sornay, P. de

Mosaic in imported canes. Rev. Agricole Maurice, 1928:13, 1928.

The author suggests that the virus may be present in apparently immune canes. A brief paper suggesting mosaic may be dormant in eanes.

\section{Sorokin, Helen [Petrovna]}

The destruction of the chloroplasts in tomato mosaic. Phytopathology (Abstract) 16(1):66-67, 1926.

Phenomena associated with the destruction of the chloroplasts in tomato mosaic. Phytopathology 17(6) : 363-370, 1927.

\section{Southwell, H.}

Virus diseases of potatoes and the raising of seed potatoes in

the Irish Free State. Journ. Minis. Agric. 34(1) : 19-25, 1927.

Popular account of the subject. Brief review of the work done by research workers, description of the disease, nature and the production of healthy seed are discussed.

\section{Spaeth, C. P., \& Kraybill, Henry R[eist]}

A bio-chemical study of the false-blossom disease of the cranberry. Journ. Agric. Res. 34: 35-48, 1927.

Diseased plants are higher in reducing sugar, sucrose, starch, acidhydrolyzable substances and dry matter, than healthy plants. They are lower in moisture. No difference in nitrogen content.

\section{Speare, A[lden] T[rue]}

Yellow-stripe disease. Hawaiian Planters' Record 10(4) : 381382, 1914. 


\section{Spieckermann, A[lbert]}

Beiträge zur Kenntnis der Bakterienring-und Blattrollkrankheit der Kartoffelpflanze. Jahresbericht, Vereiningung fur Angewandte Botanik, Jaarhg. 8, 1910, p. 1-19, 173-177, 1911.

Untersuchungen über die Kartoffelpflanze und ihre Krankheiten. In Gemeinschaft mit P. Kotthoff. Landwirtschaftliche. Jahrbüche, 63: 659-732, 1914.

Die Beurteilung der mosaikrankheit bet der Anerkennung.

Die Kartoffeln 2:111-113, 1922.

Popular.

\section{Spisar, $\mathbf{K}[\operatorname{arl}]$}

Einiger über die curly-leaf Krankheit der Zuckerrübe. Ztschr. Zuckerindus. Böhmen, 34:345-349, 1910.

\section{Sprecher, $\mathbf{A}[$ ndreas $]$}

Recherches mycrocopiques sur les sues végétaux. (Microscopical researches about the vegetable saps.) (Mosaic diseases and variegations.) Rev. Gén. Bot. 33:6-33, 1921.

Sreenivasaya, IM., \& Sastri, B. N.

Contributions of the study of spike-disease of Sandal (Santalum Album Linn.) I. Diastatic activity of the leaves. Journ. Indian Inst. Sci. 11A(3) : 23-29, 1928.

\& Gopalaswami Naidu, G.

Contribution to the study of spike disease of Sandal (Santalum album Linn.) Part V, Transmission of spike by budding. Journ. Indian Inst. Sci. 11 A (19) : 244-247, 1928.

This was transmitted by budding and showed symptoms in 131 days.

\section{\& Sastri, B. N.}

Contributions to the study of spike disease of Sandal (Santahum album Linn.) Part VIII. Chemical composition of tissue fluid from the leaf. Journ. Indian Inst. Sci. 12 A (17) : 239244, 1929. (Rev. Appl. Mycol. 9(5) : 277, 1930.)

Diseased plants contain less ash and calcium and more nitrogen, maltose and reducing sugar than healthy trees.

$$
\&
$$

Contribution to the study of spike disease of Sandal (Santalum album Linn.) Part IX. Chemical composition of tissue from the stem. Journ. Indian Inst. Sci. 12 A 17:245-250, 1929. (Rev. Appl. Mycol. 9(5) : 277, 1930.) 
Diseased plants contain more nitrogen, phosphorus and calcium than healthy plants.

Contribution to the study of spike-disease of sandal (Santalum albuw Linn.) Part XI. New method of disease transmission and their significance. Journ. Ind. Inst. Sci. 13 A (10): 113117, 1930.

A report of experimental work in grafting and leaf infection.

Ocurrence of manitol in spike disease of sandal (Santalum album Linn.) Nature 126(3177): 438, 1930.

Manitol appears to be one of the metabolic products of the virus.

Masking of spike-disease symptoms in (Santalum album Linn.) Nature 126(3190): 957, 1930.

The author believes that masking of the symptoms is influenced by intense sunshine and temperature.

\& Rangaswami, s.

Contribution to the study of spike-disease of sandal (Santalum. album Linn.) Part XII. Ecology of. sandal. Journ. Indian Inst. Sci. 14: A (5) : 59-65, 1931.

A survey was made to determine the relation of sandal-wood hosts to the spike disease. There is some evidence that sandal spike on certain hosts is more susceptible than on other hosts.

\section{Stahel, Gerold}

De Zeefvatenziekte (phloëmnecrose) van de Liberikoffie in Suriname. (Phloem necrosis of Liberian coffee in Suriname.) Meded. Dept. Landb. Suriname, Bul. 12, 2 p. 1917.

The author proposes the name phloem-necrosis disease due to features resembling leaf roll of potato and sereh of sugar cane.

Phloem necrosis of Liberia coffee in Suriname. Dept. Landb. Suriname Bull. 40, 31 p., 1920.

\section{\& Bunzli, $\mathrm{H}$.}

Nieuwe onderzoekingen over de zeefvatenziekte (phoëmnecrose) van den Koffi in Suriname. (New researches about phloemnecrosis of coffee in Suriname.) Indische Mercuur 53(42): 919-921, 1930.

Phloem-necrosis attacks all species of coffee (C. arabica, C. robusta) in Surinam and is the most serious disease. The living sieve tubes contains a Phytomonas sp. which is similar to $P$. Davidi, but smaller. 
Zur kenntnis dessiebrohrenkrankheit (Phloemnecrosis) des karfubaumes in Surinam. I. Mikrospische untersuchungen und infektionsversuche. (Contribution to the knowledge of the sieretube diseases (phloem necrosis) of the coffee tree in Surinam. I. Microscopic investigations and inoculation experiments.) Phytopath. Zeitschr. 4(1): 65-82, 1931.

The most serious diseases of Liberian coffee in Surinam. Not known in any other country. An organism has been found in the sieve tubes which is deseribed as Phytomonas leptovasorum.

Zur kenntnis der siebrohrenkrankheit (Phloemnekrose) des kấfeebaumes in Surinam. II. (Contribution to the knowledge of the sieve-tube disease (phloem necrosis) of the coffee tree in Surinam. II.) Phytopath. Zeitschr., 4(5) : 539-544, 1932.

The author reports excessive necrosis in diseased plants. The reddisease of Brazil shows similar symptom. The disease was observed in Pernambuco and Parahyba in 1917.

Verlag van den directeur. (Report of the Director) Suriname Dept. Agric. Expt. Ann. Rept. 1931-32: 5-34, 1933.

Continuation of previous work on sieve tube (Phloem necrosis) of coffee trees.

Zur Kenntnis der Siebröhrenkheit des Kaffeebaumes in Suriname III. (On the study of the "Sieve tube disease" (Phloemnecrosis) of the coffee tree III.) Phytopath. Zeitschr. 6(4) : 335-357, 1933.

Description of the disease and detailed account of the work done up to the present on this obscure disease.

\section{Stahl, C[orwin] E[loyd,] \& Carsner E[ubanks]}

Obtaining beet leafhoppers non virulent as to curly top. Journ. Agric. Res. 14(9) : 393-394, 1918.

Gives method of obtaining beet leafhopper which were nonvirulent as to eurly top.

\&

A discussion of Eutettix tenella (Baker) as a carrier of curlytop of sugar beets. Journ. Econ. Ent. 16(6) : 476-479, 1923.

A mosaic of corn. Proc. 2nd Conf. Internat. Soc. Sugar-Cane Technologists 1927: 85-87, 1927.

The most common mosaic of corn in Cuba produces stripping. It is earried from corn to corn by Peregrimus maidis. The sugar-cane mosaic is carried from cane to corn by Aphis maidis. 
Corn stripe disease in Cuba not identical with sugar-cane mosaic. Trop. Plant Res. Foundation Bull. 7:3-11, 1927. (Rev. Appl. Ent. Ser. A. 17:420, 1927; Rev. Appl. Mycol. 7:158-160, 1927.)

This paper gives proof that the corn-stripe disease of Cuba which is similar to sugar-cane mosaic is different. The disease is transmitted by a leafhopper (Peregrinus maidis, Ashm.) and apparently not transmitted by Aphis maidis, Fitch.

\section{\& Faris, J[ames] A [braham]}

El comportamiento de las nuevas cañas P. O.J. en relación con la enfermedad del mosaico de la caña de azúcar en Cuba. (The behavior of the new P.O.J. canes toward mosaic.) Est. Exp. del Club Azucarero de Cuba, p. 13, 1929, (Trop. Plant Res. Foundation, Bull. 9, 12 p., 1929.)

The authors discuss the comparative resistance of several varieties, the results of inoculation of several varieties by means of Aphis maidis. The paper closes with a discussion of resistance, immunity and tolerance.

\section{Stakman, E[lvin] C[harles]}

Raspberry mosaic. Minnesota Hort. 53(3) : 85-87, 1925.

\section{Stanley, W. M.}

The action of trypsin on tobacco-mosaic virus. Phytopathology (Abstract) 24(1): 18, 1934.

\section{Standford, E[rnest] $\mathbf{E}$ [lwood], \& Davy, E[dward] D[awson]}

Alkaloidal content of daturas affected by mosaic injury. Science, n.s. 58(1509) : 450-451, 1923.

\section{Staner, $\mathbf{P}$.}

Belgian Congo: A new disease of sisal. Int. Bull. Plant. Protect. 3(12) : 183, 1929. (Rev. Appl. Mycol. 9: 316, 1930.)

Note on a filterable virus disease of sisal, apparently new.

Mosaïque des feuilles de manioc. (Mosaic of Cassava leaves.) Bull. Agric. Congo Belge, 22(1) : 75-80, 1931.

A brief description of inoculations and filtration experiments.

\& Verplancke, G[ermain]

Un état pathologique du Sisal au Congo Belge. Bull. Agr. Congo Belge 21:864-866, 1931.

\section{Starrett, Ruth Colvin}

A new host of sugar-beet curly top. Phytopathology 19(11): 1031-1035, 1929. 
The author gives proof that Oxalis stricta is a susceptible host to the curly-top virus.

Stell, F.

Sugar-cane mosaic in Trinidad. Int. Sugar Journ. 31(368): 414-415, 1929. (Rev. Appl. Mycol. 9(2) : 131-132, 1930.) A brief report.

Stepanoff, K. IM.

(Some observations on the curling of tomato leaves in the district of Astrakham.) Comment. Inst. Astrachanesis ad defensionem plantarum 2(4) : 41-54, 1930.

The author believes that the disease he is dealing with is the same or similar to that described by Güssow (Phytopath. 11(9): 380-383, 1921.) Evidence indicates that a virus is the causal agent.

\section{Stevens, Neil E[verett]}

Field observations on false blossom of the cultivated cranberry. Phytopathology 15(1) : 85-91, 1925.

\section{\& Sawyer Jr., W[illiam] H[ayes]}

The distribution of cranberry false blossom. Phytopathology 16(3) : 223-227, 1926.

The first statement in the literature that this disease is infectious.

The false blossom situation. Amer. Cranberry Growers' Assoc. Proc. Ann. Meeting 57:20-27, 1927.

Report of eight years' field studies. Conclusions reached that the disease is infectious and spread by insects. Control measures are discussed.

The false blossom situation in 1928. Wisconsin Cramberry

Growers' Assoc. Proc. Ann. Meeting. 42:17-22, 1928.

The spread of eranberry false blossom in the United States. $\amalg$. S. D. A. Cire. 147, 18 p., 1931.

A very excellent discussion of the subject as indicated by the title.

Losses due to cranberry false blossom in New Jersey. Int. Bul. of Plant Protec. 7(3) : 53, 1933.

Popular.

\section{Stevenson, John A[lbert]}

Enfermedad de la caña de azúcar en Puerto Rico. (Sugar-cane disease in Puerto Rico.) Mundo Azucarero 5(1) : 19-24, 1917. 
An epiphytotic of cane disease in Puerto Rico. Phytopathology $7(6): 418-425,1917$.

La nueva enfermedad de la caña. (The new sugar-cane disease.) Puerto Rico Ins. Expt. Sta. Circ. 11, 12 p., 1917. (Louisiana Planter \& Sugar Manufacturer, 59:76-78, 1917; Agric. News Barbados, $16: 286,1917$.

A paper on the sugar-cane mosaic in Puerto Rico.

Report of the Pathologist for 1917. Ins. Expt. Sta. Puerto Rico Ann. Rpt. 1916-17: 37-77, 1917.

A report on the presence of sugar-cane mosaic in Puerto Rico.

La enfermedad nueva de la caña. (The new sugar-cane disease.) Rev. Agric. Puerto Rico, 1(1) : 18-25, 1918.

A detailed popular account of sugar cane mosaic. The author states that the disease appeared to be in the Island for several years previously; but very recently that it has attracted attention and become a serious menace to the sugar industry in Puerto Rico. The author discusses the disease giving symptoms, suseeptible varieties, means of transmission and control measures.

Notas sobre medios de combatir el matizado de la eaña. (Notes on how to control sugar-cane mosaic.) Rev. Agric. Puerto Rico, 2(2): 11-12, 1918.

Brief notes devising the means to fight mosaie of sugar cane.

La enfermedad del mosaico del tabaco. (Tobaceo mosaic disease.) Rev. Agric. Puerto Rico 2(1) : 39-44, 1918.

El matizado de la caña. (Sugar-cane mottling.) Rev. de Agric. de Puerto Rico, 2(1):51-52, 1918.

Brief note stating that mosaic is due to virus and not to fertilizers or soil conditions.

The mottling or yellow-stripe disease of sugar cane. Journ. Dept. Agric. Puerto Rico, 3(3) : 3-76, 1919.

A very lengthy paper giving distribution on the Island, rate and manner of spread, varietal susceptibility, symptoms, field culture relations, possible causes and methods of transmission, plot experiments and methods of control. 
Control of sugar-cane mottling disease. Sugar 23:92-95; 539554, 1921.

urves a description of the disease and advises the use of immune or resistant varieties.

\section{Stewart, F[red] C[arlton]}

Two destructive lily diseases. New York, (Geneva) Agr. Expt. Station. Ann. Rept. 1895: 520-524, 1896.

First record of the virus disease on Bermuda lily.

Potato diseases on Long Island in the season 1895. New York State Agric. Expt. Sta. Bull. 101: 83-86, 1896.

Two destructive lily diseases. New York (Geneva) Agric. Expt. Sta. Ann. Rpt. 1895 : 520-524, 1896. The first record of the lily mosaic.

Another stem blight of potatoes. New York State Agric. Expt. Sta. 15th Ann. Rpt. 1897 : 509-510, 1897.

The communicability of potato stem blight. New York State Agric. Expt. Sta. 16th Rpt., 1898: 421-423, 1898.

\section{\& Eustace, H[arry] J[oshua]}

Raspberry cane blight and raspberry yellows. New York Agric. Expt. Sta. (Geneva) Bull. 226: 331-366, 1902.

A brief record.

\section{\& Sirrine, $\mathbf{F}[\mathrm{rank}] \mathbf{A}[$ twood]}

The Spindle-Sprout Disease of Potatoes. New York (Geneva) Agric. Expt. Sta. Bull. 399:133-143, 1915. Popular Edition of the same. (Phytopathology (Abstract) 4:395, 1914.)

A study of field conditions. Cause unknown.

Observations on some degeneration strains of potatoes. New York Agric. Expt. Sta. Bull. 422, 12 p., 1916.

Further studies on the effect of missing hills in potato field and on the same seed tuber. New York Agric. Expt. Sta. (Geneva) Bull. 389, 52 p., 1921.

Raspberry mosaic. Fruit diseases problems of to-day. Proc. N. Y. State Hort. Soc. 1922: 61-69, 1923. 
Control of leaf roll and mosaio in potatoes by isolating and roguing the seed plant. New York (Geneva) Agric. Expt. Sta. Bull. 522, 14 p., 1924.

Report of experimental data obtained during five seasons with leaf roll and mosaic diseases of potatoes.

Observations on masking of raspberry mosaic by high temperature. Phytopathology (Abstract) 15(1): 80, 1926.

\section{, \& Glasgow, Hugh}

Aphids as vectors of leaf roll among sprouting potato tubers. New York. (Geneva) Agric. Expt. Sta. Tech. Bull. 171, 21 p., 1930.

After tests made by the authors, conelusions were reached that aphids are capable of spreading leaf roll among sprouting seed potatoes, confirming Murphy's assertion in Ireland. Control methods are given.

Aphids on potato sprouts. New York Agric. Expt. Sta. Cire. 119, 6 p., 1931.

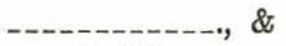

Aphids as vectors of leaf roll among sprouting potato tubers. Phytopathology (Abstract) 21(1) : 103-104, 1931.

\section{Stewart, V[ern] B[onhane], \& Reddick, Donald}

Bean mosaic. Phytopathology (Abstract) 7(1):61, 1917.

\section{Stift, $\mathbf{A}[$ nton]}

(Sugar-beet and potato diseases in 1908.) Centbl. Bakt. II Abt., 23(6-9) : 173-192, 1909.

(Some of the more important contributions in 1909 on the diseases of sugar beets and potatoes.) Centbl. Bakt. II, Abt. 26 $(18-19): 520-560,1910$.

(A review of literature relating to diseases of sugar beets and. potatoes.) Centbl. Bakt. I Abt., 33(17-19) : 447-496, 1912.

\section{Stock, J[ohn] E[wald] van der}

Proeve cener verklaring der gelestrepenziekte en der serehziekte.

(Proof of a hypothesis of the yellow-stripe disease and the sereh disease.) Meded. Prof. Oost-Java Series 4, No. 36 : 457477, 1907. (Arch. Java Suikerinders. Jaarg. 15:581-601, 1907.) 


\section{Stone, George E[dward], \& Chapman, G[eorge] H[enry]}

Report of the botanists. Massachusetts Agric. Expt. Sta. Rpt. p. 120-150, 1907.

Investigations relating to mosaic disease. Massachusetts Agric. Expt. Sta. Rept. 20:136-144, 1908.

Stone, R[oland] E[lisha], \& Howitt, John Eaton

Experiments with winter blight or streak of tomatoes. Phytopathology (Abstract) 12(1):41, 1922.

Winter blight or streak in tomatoes. Phytopathology 15(5): 300, 1925.

The author reports success in controlling tomato streak or winter blight in commercial greenhouses by increasing phosphoric acid and potash in fertilizers.

Stoneberg, H[ugo] F.

The productiveness of corn as influenced by the mosaic disease. U. S. D. A. Tech. Bull. 10, 18 p., 1927.

The results of extensive experimental work showing the importance of this disease.

\section{Storey, H[arold] H[aydon]}

The major cane diseases. South African Sugar Journ. Cong. \& Exhibit. p. 54-61, 1923.

Treatment of mosaic in Natal. South African Sugar Journ. 7 (9) : 745-747, 1923.

A disease of maize and its probable relation to the control of streak disease in Uba cane. South African Sugar Journal, 8: 647-649, 1924.

Disease of sugar cane of the mosaic type in South Africa. Part I. Journ. Dept. Agric. South Africa, 9(2):108-117, 1924. (Rev. Appl. Ent. Ser. A 12:469; Rev. Appl. Mycol. 4:122123, 1924.)

A discussion of conditions with reference to the disease in South Africa.

The transmission of a new plant virus disease by insects. Nature 114(2859) : 245, 1924. (Rev. Appl. Mycol. 3:685-686, 1924.) 
Transmission of a maize disease by Balclutha sp. The disease is. similar to the mosaic of cane, maize and other grasses. The sugarcane mosaic is transmitted by Aphis maidis.

Streak disease in Uba cane. Louisiana Planter \& Sugar Mfg. $73(15)$ : 268-270. (South African Sugar Journal Congress \& Exhibition number p. 63-66; Rev. Appl. Mycol. 4 : 123, 1924.) A study of losses due to this disease. Losses 10 per cent.

Streak disease an infectious chlorosis of sugar cane, not identical with mosaic disease. Rpt. Imp. Bot. Conf. (London) July, 1924. Proc. p. 132-144, 1924. (Rev. Appl. Mycol. 4:442-443, 1924.)

The author gives evidence that the disease is an infectious ehlorosis.

The influence of streak disease upon the yield of Uba cane. South African Sugar Journ. 8(7) : 519-522, 1924. (Rev. Appl. Mycol. 3: 686, 1924.)

Experimental plots showed losses ranging from 30 to 50 per cent.

Streak disease of Uba cane. Journ. Dept. Agric. South Africa, $10: 532-537,1925$.

Streak disease of sugar cane. Union of South Africa Dept. Agric. Sci. Bull. 39, 30 p., 1925. (Rev. Appl. Mycol. 5:1-2, 1925.) Facts About Sugar, 20(40): 953, 1925.

The author gives a review of the literature, the distribution, the symptoms, list of susceptible varieties of cane and a list of other species of plants. The disease causes losses of 12 to 50 per cent and is transmitted by a jassid leafhopper, Balclutha mbila (Naude). The author recommends the use of new varieties.

Streak disease of eane. South African Sugar Journ. Annual, p. $113-118,1925$.

Sugar-cane diseases of the mosaic type in South Africa. Part II. South Africa Dept. Agric. Journ. 10(6) : 532-537, 1925. (Rev. Appl. Ent. ser. A. 13:393, 1925. Rev. Appl. Mycol. $5: 2,1925$.)

The Transmission of streak disease of maize by leafhopper, Balclutha wibila, Naude. Ann. Appl. Biol. 12(4), 433-439, 1925. Although Uba cane is immune to mosaic, it is susceptible to streak. The disease is transmitted by leaf-hopper, Balclutha mbila (Naude). 


\section{\& Bottomley, A[nnie] III.}

Transmission of rosette disease of the ground nut. Nature 116: 97-98, 1925. (Agric. Journ. India 21:68-69, 1926.)

This disease is transmitted by Aphis leguminosae.

Interspecific cross-transmission of plant virus disease. South African Journ. Sci., 23:305-306, 1926. (Rev. Appl. Mycol.. 6: 377, 1927.)

The streak disease is transmitted from maize to maize by Balclutha mbila. Also from Uba to Uba cane. Failed to transmit from maize to Uba. Disease also reported on Eleusine indica and Digitaria horizontalis.

Recent researches on plant virus disease. South African Jour. Sci. (Summary), 23:307, 1926. (Rev. Appl. Mycol. 6:377, 1927; Int. Sugar Journ. 29: 345, 487, 1927.)

A summary of recent work.

The cane disease situation. Urgency of the need for the control of mosaic. African Sugar \& Cotton Planter 2(7) : 11-15, 1926. (Rev. Appl. Mycol. 6: 54, 55, 1926.)

A warning as to the necessity for control.

The cane disease situation. Proc. 4th Ann. Congress So. Africa Sugar Assoc. 1926:69-73, 1926. (The Planter and Sugar Manuf. 78(2) : 28-30, 1927.)

The author believes that mosaic can be eradicated by the use of resistant varieties.

Rosette disease of ground nuts (Aphis leguminosae (Theo.).)

Proc. S. \& E. African Agric. Conf. Nairobi p. 213-214, 1926.

Streak disease of Uba cane. Jamaica Dept. Agric. Microb. Cire. 6: 88, 89, 1926 .

Strain of the viruses affecting the graminea. Proc. Conf. Int. Soc. Sugar $\lrcorner$ Cane Tech. 2: 87-88, 1927.

Control of streak disease on maize and sugar eane. Proc. South \& East Agric. Conf. 1926, p. 212, 213, 1927. (Rev. Appl. Ent. Ser. A. 15: 569, 1927.) 
Transmission studies of maize streak diseases. Ann. Appl. Biol. 15 (1) : 1-25, 1928.

After the Balclutha (Cicadula) mbila feeds on diseased corn, 12-48 hours at $30-35$ degrees $\mathrm{C}$. incubation is necessary before it can transmit the disease. At lower temperature, a longer time is necessary.

\section{\& Bottomley, A[nnie IM]}

The Rosette Disease of Peanuts (Arachis hypogaea. L.) Ann. Appl. Biol. 15(1) : 26-45, 1928.

The authors give proof that it is a virus disease and that it is carried by Aphis leguminosae.

Plant pathology. First Ann. Rpt. East African Agric. Res. Stat., Amani 1928-1929:12, 1929. (Rev. Appl. Mycol. 9(2): 88, 89, 1930.)

A record of mosaic of sugar cane, streak of maize, rosette of ground nut curly-leaf cassava and mosaic of tabaceo.

A mosaic virus of grasses, not virulent to sugar cane. Ann. Appl. Biol. 16(4) : 525-532, 1929.

A discussion of a virus disease of maize and sorghum which is indistinguishable from sugar-cane mosaic. It is carried by Aphis maidis.

\section{IIcClean, A[lan] P [ercy] D[ouglas]}

The transmission of streak disease between maize, sugar cane and wild grasses. Ann. Appl. Biol. 17(4): 691-719, 1930.

The authors give the results of transmission experiments with the streak disease on maize, sugar cane, Digitaria horizontalis and Eleusine indica. The virus from maize does not produce permanent infection in cane. The virus from Uba produces a mild form of the disease in maize. The disease occurs in P. O.J. 213 previously supposed to be immune. The authors give a list of wild grasses believed to be susceptible. The streak from $D$. horizontalis can be transmitted to maize and back but not to cane. $E$. indica was not infested with virus from cane or maize but was infested with virus from P. O.J. 213.

Plant Pathology. Second Ann. Rpt. East African Agric. Res. Stat. Anıani. 1929-30, 1930.

The bearing of insect-vector on the differentiation and classification of plant viruses. Deuxiéme Congr. Internat. Path. Comp. Paris II. Comptes Rendus \& Communications 2:471-479, 1932.

Review of our knowledges in regard to insect vectors and its relation to the virus disease type. 
The inheritance by a leaf-hopper of the ability to transmit a plant virus. Nature $127(3216)$ : 928, 1931. (Proc. Roy. Soc. B $112(774): 46-60,1932$.)

Certain individuals of Cicadulina mbila inherit the ability to transmit the streak disease of corn. Others do not. This character can be fixed by breeding.

A new virus disease of the tobacco plant. Nature 128(3222): - 187, 188, 1931.

A new virus disease in Tanganyika. It has been transmitted by grafting and by an undetermined aleyrodid.

The filtration of the virus of streak disease of maize. Ann. Appl. Biol. 19(1) : 1-5, 1932.

This disease has not been transmitted from plant to plant by mechanical methods but is transmitted by Cicadulina mbila. Juice from diseased plants plus sucrose up to 10 per cent ean be taken through membranes by the insect and inoculated into corn. The virus will pass Chamberland L1 and Berkefeld V filter (which retains Bacillus pyocyanem), Chamberland L3 and Berkefeld N. Candles. It did not pass a Seitz E. K. disc.

Leaf curl of tobaceo in Southern Rhodesia. Rhodesia Agric. Journ. 29 (3) : 186-192, 1932.

The leaf curl, crinkling or frenching of Rhodesia are the same as crinkly dwarf in South Africa, Cabbaging in Nyasaland and Kroepoch in Java. It is transmitted by Bemisia gossypiperda.

Investigation on the mechanism of the transmission of plant viruses by insects. I. Proc. Roy. Soc. B $113: 463-485,1933$.

The author gives the results of studies which lead to the conclusion that the streak virus taken in by Cicadulina mbila passes through the wall of the intestine and into the blood. C. mbila was not successfully inoculated with the virus of maize stripe and mosaic diseases; nor Peregrimus maidis and Aphis maidis with the virus of streak.

Report of the Plant Pathologist. East African Res. Stat. Amani. Fifth Ann. Rpt. 1932-33: 13-17, 1933.

This report is wholly on studies on the following virus diseases: Sugar-cane streak disease, tobacco and cassava mosaic.

\section{Stormer, K [urt]}

The dying of fruit trees and the leaf-roll disease of the potato. Jahresber. Ver. Angew. Bot. $7:$ 119-170, 1909. 
Die Blattrollkrankheit der Kartoffel. (Leaf-roll disease of potato.) Ill. Landwirtschaftliche Zeitung. Jahrg. 30(60) : 565$566,1910$.

Plant diseases for the year 1909 of special notice. Landw. Wchnschr. Sachsen, 12 (2) : 10-12, (3) : 19-21, (4) : 27-29, 1910. \& Morgenthaler, $\mathrm{O}$ [tto]

The leaf-roll disease of potatoes in Saxony. Naturw. Ztschr.

Forst. u. Landw., 9(12): 521-551, 1911.

Abban und wiederanffrischung von Kartoffelsorten durch Bodeneinflüsse. Ill. Landwirtschaftliche Zeitung. Jahrg. 51:177179, 1911.

\section{Stout, $\mathbf{A}$ [rlow] $\mathbf{B}[$ urdette]}

Why we fail with garden lilies. Journ. New York Botanical Garden 28: 285-296, 1927.

The author gives two pages to the importance of virus diseases.

Virus diseases of lilies in England. Garden Chron. 88(2296): 532-533, 1930.

A survey of lilies infected with virus diseases and the insect vectors.

\section{Stout, Gilbert L[eonidas]}

A mosaic type in certain cases of peach yellows occurring near potatoes. Phytopathology (Abstract) 20(1):126, 1930.

The peach yellows situation in Illinois. U.S.D.A. Br. Plant Indus. Plant Disease Reporter 14(4) : 28-32, 1930. Mimeographed.)

\section{Stover, W[ilmer] G[arfield]}

Experiments with tomato streak. Phytopathology (Abstract) $18(1): 154,1928$.

\section{\& Vermillion, IM. T.}

Some experiments with a yellow mosaic of tomato. Phytopathology (Abstract) 23(1):34, 1933.

\section{Stranviak, F[rantisvek]}

La mosaicá virus de la Vigne. (The virus mosaic of the vine.) Second Intern. Congr. Path. Comp. (Paris) 1:367, 1931. 


\section{Blattny C[tibor Eugen Maria Karll], \& Klecka, A.}

Mosaika revy vinne. (Predbezne). (Mosaic of the vine.) Preliminary report. Ochrana Rostlin, 11: 89-98, 1931.

A description of disease which ean be transmitted by grafting, by injection of juice of diseased plant and by Leconium corni.

\section{Strong, Richard P[earson] \& Shattuck, G[eorge] C[heever]}

Plant diseases. (The African Republic of Liberia and the Belgian Congo.) Contr. Dept. Trop. Med. \& Inst. Trop.. Biol. \& Med. 5. (Harvard African Expedition 1926-27) p. 389410, 1930.

Mandioca (Manihot palmata) plants through Liberia and in some districts of Belgian Congo were found to be affected by a disease of the mosaic type.

\section{Stuart, W[illiam]}

Plant lice transmit mosaic. Potato Mag. 2(6):16, 1919.

\section{Stucky, Henry Perkins}

Plant diseases investigations of the Georgia Experiment Station.

Georgia Sta. Rept. 1920:4-5, 1920.

\section{Sturgis, W[illiam] C[odman]}

Conn. Stat. Bul. 111, 1892; 115: 124, 1893.

Brief note describing peach yellows, important as an early record.

Preliminary notes on two diseases of tobacco. Connecticut Agric.

Expt. Sta. Ann. Rpt. 1898, 22 : 242-260, 1899.

Gives description and results of studies. Believes the disease is physiological. Discusses the calico or mosaic of tobacco with reference to cause, soil, transmission and preventive measures. Also a spotting of tobaceo which is probably the same as Iwanowski's "pockenkrankheit".

On the effects on tobacco, of shading and the application of lime. Connecticut Agric. Expt. Sta. Ann. Rpt. 23:252-261, 1899.

On the so-called "Grain" or wrapper tobacco. Connecticut Agric. Expt. Sta. Ann. Rpt. 23: 262-264, 1900.

\section{Sumners, E. IM.}

Mosaic disease in Co. 281 cane. Sugar Bull 11(23) : 3-4, 1933. (Facts About Sugar (Abstract 28(10) : 398, 1933.)

Account of the occurrence of mosaic disease in Co. 281 cane in Louisiana. 


\section{Sundaranaman, $\mathbf{S}$.}

Mosaic disease of sugar eane in South India. Madras Agric. Dept. Bull. 92:5-13, 1928. (Rev. Appl. Mycol. 8:62, 1929.) The result of studies on resistant varieties.

The "clump disease" of Ground-nuts. Madras Agric. Dept. Year Book, 1926: 13-14, 1927.

Administration Report of the Government Mycologist, Coimbatore, for 1928-29. (Reprinted from Rpt. Dept. Agric. Madras Presidency, for the official year 1928-29, p. 27, 1929.) (Rev. Appl. Mycol. 9(2) : 87-88, 1930.)

Contains a record of sugar-cane varieties resistant to mosaic.

\section{Suzuki, U[metaro]}

Report on investigations on the mulberry-dwarf trouble, a disease widely spread in Japan. Imp. Univ. Tokyo, Coll. of Agric. Bull. 4(3) : 167-226, 1900.

Chemische Physiologische Studien uber die Schrumpfkrankheit des Maulberrbaumeseines in Japan sehr weit verbeitete Krankheit Ztschr. Pflanzenkrank. 12:203-226, 258-278, 1902.

\section{Swezy, Olive, \& Severin, Henry H[erman] P[aul]}

A filterable (Rickettsit-like) microorganism from Eutettix tenelle and the sugar beet, both infected with curly top. Phytopathology (Abstract) 19(12): 1143, 1929.

Factors influencing the minimum incubation periods of eurly top in the beet leaf hopper. Phytopathology 20(1):93-100, 1930.

A study of the intestinal tract of Eutettix tenellus. Bacteria were found and evidence that the juice could be ejected from the oesophagus.

\section{\& Severin, H[enry] H[erman] P[aul]}

A Rickttsia-like microorganism in Eutettix tenellus (Baker.) The carrier of curly top of sugar beets. Phytopathology 20 (2) : 169-179, 1930.

The E. tenellus harbors two organisms which can not be separated on morphological grounds. One passes the filter and the other does not.

Swieten, H. J.

De tabaksteelt te Elst en omstreken in de Opper-Betuwe Tijdschrift ter bevordering van Nijverheid. Tweede reeks. 5 : 145-167, 1857. 


\section{Szembel, S[tefan Ju]}

(A few notes on tomato diseases in the district of Astrakhan.) Comment Inst. Astrochanensis ad defensionem plantarum 2 (4) :32-34, 1930.

Brief notes on leaf curl, and mosaic are given; mosaic is transmitted according to the author's report by the mite Tetrannychus telarius.

(Prevalence of the chief diseases of cultivated plants in the district of Astrakhan during the period 1926 to 1929.) Comment Inst. Astrachanensis ad defensionem plantarum, 2(4) : 61-80, 1930.

Brief notes on degeneration diseases of potato.

\section{Takada, K[azuo]}

Studies in the stripe leaf disease of barley. Journ. Tokyo Nogyo Daigaku (Tokyo Agric. Eoli.) 2:1-87, 1927.

\section{Takahashi, W[illiam] N[oboru], \& Rawlins T[homas] E[Isworth]}

Electrophoresis of tobacco mosaic virus. Hilgardia 4(15):441463, 1930. (Phytopathology 30(10): 855, 1930.)

The authors give a review of the literature bearing on this phase of the subject and the results of their own experiments which they summarize as follows: Unpurified tobacco mosaic virus migrated to the anode during electrophoresis between $\mathrm{pH} 4$ and $\mathrm{pH} 9$. No migration of the virus was detected between $\mathrm{pH} 3 \& 1.2$.

Method of determining shape of colloidal particles: application in study of tobacco mosaic virus. Proc. Expt. Biol. \& Med. 30:155-157, 1932.

Rod-shaped particles in tobacco mosaic demonstrated by stream double refraction. Science 77(1934): 26-27, 1933.

The authors give more details of their method and technique used in the demonstration by means of stream double refraction that the particles in the tobacco-mosaic virus are rod-shaped.

\section{$\&$}

Stream double refraction exhibited by juice from both healthy and mosaic tobacco plants. Science n.s. 77(1994): 284, 1933.

Continuation of previous experiments. The observation of recent work showed that the juice from unfrozen healthy leaves exhibited marked stream double refraction. The phenomenon was not manifested by juice from unfrozen healthy tobacco leaves subjected to the treatment with safranin. 
372 THE JOURNAL OF AGRICULTURE OF THE UNIVERSITY OF P. R.

, \&

Evidence regarding the shape of tobacco mosaic virus particle. Phytopathology (Abstract) 23(1) : 34-35, 1933.

\& Christensen, Ralph J.

The virucidal action of high frequency sound radiation. Science N.S. 79(2053):415-416, 1934.

The author describes the procedure they followed in testing the effeet of high frequency sound radiation on mosaic-tobaceo leaves. The results obtained indicate that the tobaceo mosaic virus is inactivated by high frequency sound radiation.

Takami, $\mathbf{N}$.

(Stunt disease of rice and Nephotettix apicolis.) Journ. Agric. Soc. Japan 241:22-30, 1901.

\section{Takimoto, $\mathbf{S}$.}

(On the mosaic disease of chinese cabbage and other crucifers.) Jap. Hort. 42(6) : 5-7, 1930.

\section{Taubenhaus, J[acob] J[oseph]}

The disease of the sweet pea. Delaware Agric. Expt. Sta. Bull. 106 : 93 p., 1914.

Reviews subject and gives first description of disease on sweet pea. Can be transmitted by needle puncture and aphids. Believes it is caused by bacteria or protozoa.

Sweet pea diseases and their eontrol. Trans. Mass. Hort. Soc. 1916 Rpt. 1: 131-143, 1916.

Taylor, G. IM.

Degeneration of potatoes. Gard. Chron. 63:13, 1918. Popular.

\section{Taylor, W[illiam] A[lton]}

The leaf-cut disorder of cotton seedlings. U.S.D.A. Ann. Rpt. 120 Br. of Plant Product. Rpt. for 1913 p. 16.1913.

\section{Tchirch, A.}

Ueber Sereh, die wichtigste aller krankheiten des Zuckerrohres in Java Schwelz. Wochenschrift, f. Pharmazie 29(6):47$52,1891$.

Tedin, $\mathrm{H}$.

Bladrollsjuka hos potatis. (Leaf roll of potatoes.) Sveriges Utsädesf. Tidskr. 1913: 290-395, 1913. 
Tehon, Leon $R$ [oy], \& Stout, G[ibert] L[eonidas]

Peach yellows in Illinois. Illinois State Nat. Hist. Surv. Bot.

Cir. 1:23 p., 1929.

A report of survey work.

Observations on peach yellows in Illinois. Trans. Illinois State Hort. Soc. 1931. 75:183-195, 1932.

Some historical data in regard to that disease stating that reliable reports indicate that it was observed as early as 1889. Considerations are given as to the spread and possible insect vector (Myzus persicae).

\section{Tempany, H[arold]}

Annual Report of the Department of Agric. Mauritius. 1921, 1922.

Reports on mosaic present.

\section{W[alker]}

Earle, $\mathbf{F}$ [ranklin] S[umner], \& Brandes $\mathbf{E}[$ lmer]

Mosaic disease in Natal. South African Sugar Journal 8:269$271,1924$.

These authors have written independently giving their views on the mosaic situation in Natal based on the reports of H. H. Storey.

Teodoro, N. G., \& Serrano, F[elicísimo] B.

Abaca heart rot and bunchy-top disease and their control, Heterodera radicicola. Philippine Agric. Rev. 19:243-247, 1926.

\section{Thatcher, $R$ [oscoe] W[ilfred]}

Raspberry mosaic. New York (Geneva) Agric. Expt. Sta. Ann. Rpt. 1922, 41: 51, 1923.

Brief notes.

Thompson, H[arry] S[tephen]

On the preventions of curl and dry-rot in potatoes. Journ. Royal Agric. Soc. England 6:161-174, 1845.

Thornton, IVI. H., \& Kraybill, H. R.

Further studies on a noninfectious leaf-deforming principle from mosaic tomato plants. Phytopathology (Abstract) 24 (1) : 19, 1934.

\section{Thornberg, W[alter] S[trickland]}

Western tomato blight. Better Fruit 6:14, 1912. 


\section{Trupp, T[homas] C[yril]}

The transmission of "Mosaic" disease in hops by means of grafting. Ann. Appl. Biol. 14(2) : 175-180, 1927.

A brief paper giving results of transmission by grafting.

\section{Thung, T. H.}

Physiologisch onderzoch met betrekking tot het virus der bladrolziekte van de aardappelplant, Solanum tuberosum L. (Physiological investigations in relation to the virus of potato leaf-roll diseases. (With English Summary.) Tijdschr. Plantenziekt. 34(1-2) : 1-74, 1928.

Studies which lead the author to believe the excess of starch in leaf-roll potato plants is due to disturbed translocation and not to disturbed enzymatic activity.

Over knolentingen die ter bestudeering der virusziekten van de aardappelplant worden mitgeverd. (On tuber-grafts made for studying potato virus diseases.) Tijdschr. Plantenziekten. 34(7) : 195-199, 1928.

The virus from a potato half tuber passed to a healthy half tuber without a union. The transmission is mechanical.

Smetstof en plantencel by enkele virusziekten van de Tabakplant. (Infectives principle and plant cell in some virus diseases of the tobacco plant.) Handelingen ó de Nederl,-Ind. Nature wetensch. Congr. 1931. p. 450-463, 1932.

The author separated the active agent of the white or whitish yellow mosaic and common mosaic from a tobaceo plant infected with both. He believes the former which is sporadic in Java, to be the same as Johnson's and McKinney's yellow mosaic. He is of the opinion that tobacco-mosaic virus is not a living agent but a dead toxic substance normally in the plant. This is in accordance with the theory advanced by Hunger in 1905 .

De Kulr-an Kroepoek-Ziekten van Tabac en de corzaken van here verbreiding. (The curl and crinkle disease of tobacco and the causes of their dissemination.) Proefstat. vors-tenandsche Tobak. Meded. 72:1-54, 1932.

A virus disease that can be transmitted by grafting and the white fly (Bemisia $s p$.) The disease has been transmitted to tomato, $N$. glauca and $N$. rustica. 
Bestrijding der Kurl-en Kroepoek-ziekte van tabak. (The control of the curl-and crikle diseases of tobacco.) Meded. Proefst. Vorstenl. Tabak Java 78, 18 p. 1934. (English Summary p. 18.)

\section{Tice, C[ecil]}

Mosaic disease of potato. Agric. Journ. British Colombia. 7: 77, 1922.

Leaf-roll disease of the irish potato. Agric. Journ. British Colombia. $7: 10-11,1922$.

A popular discussion.

\section{Tiedjens, V. A.}

Yellow pickle in greenhouse cucumber. Massachusetts Agric. Expt. Sta. Bull. 225, 8 p., 1925.

\section{Tilford, P[aul] E[dward]}

Potato Leaf-roll in Ohio. Ohio Agric. Expt. Sta. Bimonthly Bull. 11(2) : 55-59, 1926.

A general discussion and estimates of losses due to this disease.

Ohio potato disease. Ohio Agric. Expt. Sta. Bull. 432. 38 p., 1929. (Rev. Appl. Mycol. 9(1):51. 1930.)

Brief notes. Popular.

Tims, E[ugene] C[hapel], \& Edgerton, C[laude] W[ilbur]

Behavior of mosaic in certain sugar cane varieties in Louisiana.

Amer. Journ. Bot. 18(8) : 649-657, 1931.

The field observations made by the authors led them to discuss the behavior of mosaic in certain sugar-cane varieties, mostly P.O.J. canes.

\section{Tisdale, W[illiam] B[urleigh]}

Tobaceo disease investigations. Florida Sta. Rpt. 1922:128139, 1922.

Plant pathology. Florida Agric. Expt. Sta. Rpt. 1929: 68-81, 1929.

Record on spindle tuber of potatoes.

Tolaas, A. G.

The production of mosaic-free Triumphs. Amer. Potato Journ. 3(9) : 301-302, 1926.

Popular. 


\section{Tollenaar, D[irk]}

Jaarverslag Mei 1928-30 April, 1929. (Annual report, 1st May, 1928 to 30th April, 1929.) Proefstat. Vorstenlandsche Tabak, Meded, 62, 55 p., 1929. (Rev. Appl. Mycol. 9(2) : 137-138, 1930.)

Contains some data on mosaic of tobacco.

\section{Tomei, B[ertani]}

Malattie delle Plante Erbacee. (Diseases of herbaceous plants.) Urbino, Italy p. 111, 1923.

\section{Tompkins, C[hristian] II[ilton]}

Effect of intermittent temperature on potato mosaic. Phytopathology (Abstract) 15(1): 46, 1925.

Influence of the environment on potato mosaic symptoms. Phytopathology 16(9): 581-610, 1926.

This paper gives the results of much valuable data obtained from experimental work under control conditions. The greater part of the work has to do with temperature.

\section{Tower, W[inthrop] V[ose]}

Mottling disease of sugar cane. Porto Rico Agric. Expt. Sta. Ann. Rpt. 1919: 21-25, 1920.

Report of the Entomologist. Porto Rico Sta. Rpt. 1921: 23-26, 1921.

\section{Townley, John}

The limited duration of varieties of potato, and progressive deterioration of the plant as a species, proved by a consideration of the curl, dry-rot, and other diseases. The diseases, Regeneration \& Culture of the Potato. London, p. 67-85, 1847.

Of historical interest.

\section{Townsend, C[harles] O[rrin]}

Some diseases of sugar beet. U. S. D. A. Rpt. 72:90-101, 1902.

The curly top or western blight of the sugar beet. Science n.s. (Abstract) 23(585):426-427, 1906.

Curly-top, a disease of the sugar beet. U.S.D.A. Br. Plant Indus. Bull. 122, 37 p., 1908.

Describes the symptoms and gives brief history. Gives a rather extensive discussion of possible causes. 
Sugar beet mosaic. Science n.s. $42(1076)$ : 219-220, 1915. (Phytopathology (Abstract) 5(4):282, 1915.

An immune variety of cane. Science n.s. 49(1272):470-472, 1919. (Louisiana Planter \& Sugar Manuf. 63(3): 42, 1919. Sugar $21: 305,392,1919$.)

A discussion of the immunity of Kavangire cane to mosaic.

Disease immunity in beets. Facts About Sugar 22(33):789, 1927.

Popular.

\section{Townsend, C[harles] H[enry] T[yler]}

Notas sobre Aphis maidis (Notes on Aphis maidis.) Estac. Expt. Agric. Soc. Agri. (Perú) Circ. 5. 10 p., 1928.

\section{Trabut}

Sur la chlorose infectiouse des citrus. (Infectious chlorosis of citrus.) Compt. Rend. Acad. Sei. Paris. 156: 243-244, 1913.

Treub, II.

Onderzoekingen over serehziek suikerriet. Meded. uit 'S Lande Plantentuin 2, 1885.

\section{Trochain, J.}

La lepre de l' arachide en Senegal. (Leprosy of ground nut in Senegal.) Rev. de Bot. Appli. et d' Agri. Trop. 11(117): 330-334, 1931.

\section{Trotter, Alessandro}

Nostre conoscenze sulle virosi del tabacco ed in particolare sul "mosaico". (Our knowledge on virosis of tobaceo in particular to the "mosaic".) Boll. Tecn. R. Inst. Sperim. per le Cultizazione del Tabacchi "Leonardo Angeloni" Scafati $30(2): 81-104,1933$.

Troude, M. J.

La jaunisse de la betterave. (The yellows of the beet.) La Sucrerie Indigége et Coloniale. 48:338-340, 1896.

True, R[odney] H[oward], Black, Otis Fisher, Kelly, James W[illiam] Bunzel, Herbert H[orace], Hawkins, Lon A[drian] Jodidi, Samuel Lee, \& Kellogg, Edward $\mathbf{H}$.

Physiological studies of normal and blighted spinach. Journ. Agric. Res. 15(7) : 369-408, 1818. 
This general title includes four papers as follows: I. True, Black and Kelley. Ash content in normal and in blighted spinach. Gives the results of chemical studies. II. Bunzell, H. H. Oxidase reaction in healthy and in blighted spinach. A greater oxidase activity in diseased than in healthy plants but does not determine whether it is a cause or a symptom.

This is believed to be the same as rosette. The plants are dwarfed and sometimes completely sterile. III. True and Hawkins: Carbohydrate production in healthy and in blighted spinach. Carbohydrate accumulation greater in diseased than in healthy plants. IV. Jodidi, Kellogg and True: Nitrogen metabolism in normal and in blighted spinach. Gives the results of studies made to determine reasons for the results obtained in paper No. III.

\section{\& Hawkins, Lon $\mathbf{A}$ [drian]}

Carbohydrate production in healthy and blighted spinach. Journ. Agric. Res. 15:381-384, 1918.

\section{Tsen-Cheng.}

Sur les modifications histologiques constactées chez la pomme de terre. (Solanum tuberosum) atteinte de dégénérescence (Maladie de l' enroulement.) (Histologic modifications of potatoes attacked by leaf roll.) Compt. Rend. Sci. (Paris) $186(8): 524-526,1928$.

Histological studies on the leaves.

Sur les phénoménes de nécrose dans la pomme de terre atteinte de la maladie de l' enroulement. (Necrosis in potatoes attacked by leaf roll.) Compt. Rend. Acad. Sci. (Paris) 186 (11) : 712-714. 1928.

The author discusses the process of phloem necrosis in diseased plants.

Recherches sur la maladie de dégénérescence (enroulement) ehez Solanum tuberosum. (Researches on leaf roll disease of potato. Solanum tuberosum. 103 p., Jouve édit., 15 me Racine: Paris. Thése, Fac. Sci. Paris. 111 p., 1929.)

\section{Tsienen, S. J.}

Recherches sur l' histologie des plantes panachées et sur le mecanisme cytologique de la panachure. (Investigations on the histology of variegated plants and the eytological mechanism of the variegation.) Thesis. Fact. Sci. Nancy (France) 104 p., n.d.

Tsuji, R.

(The curly dwarf of potato.) Horticulture 11:35-39, 1919. 


\section{Turner, W[illiam] F.}

Progress in phony peach disease eradication. Journ. Econ. Entom. 26(3) : 659-667, 1933.

Report of work done.

\section{Unite, J[uan] O., \& Capinpin, J[osé] MIananjaya]}

Selection of mosaic-free cuttings of sugar cane. Philippine Agric. 15(2):67-73. 1926. (The Planter \& Sugar Manuf. 77 (8) : 147-148, 1926.)

\section{Uphof, J[ohannes] C[ornelis] T[heodorus]}

Eine neus Krankheit von Cephalanthus occidentalis. (A new disease of Cephalanthus occidentalis.) Zeitschr. fur Pflanzenkr. 31(3-4) : 100-108, 1921.

\section{Uppal, B[adri] $\mathbf{N}$ [ath]}

India: mosaic disease of chillies (Capsicum annuum.) in the Bombay Presidency. Internat. Bull. of Plant Protec. 3(7): 99, 1929. (Rev. Appl. Mycol. 9(1):10, 1930. Int. Auz. Pflanzenschutz 3:103, 1929.)

A record of heavy losses.

India: A new virus disease of Dolichos biflorus. Internat. Bull. Plant Proct. 5(9) : 163, 1931.

A disease very similar to mosaic of beans oceur on Dolichos biflorum and D. lablab.

\section{Utra, Gustavo d'}

A molestia do "mosaico" de fumo (Mosaic disease of tobacco) Bol. Agric. Sao Paulo (Brasil) 5(2):51-71, 1904.

\section{Uzel, H[einrich]}

Mitteilung uber Krankheiten und Feinde der Zuckerrübe in Bohmen in Jahre. 1907 und der mit derselben abwechselnd pultivieten Pflanzen. Zeitschr. f. zuckerindus. in Böhmen 33 : 357, 1909. (Rev. Centralbl. f. Bakt. 24; 207-271, 1909.)

Valeton, T.

Bijdrage tot de kennis der serehziekte. Proefst. Oost-Java, Batavia p. 307-338, 1891.

\section{Valle Zeno, Rafael del}

Mottling or yellow stripe disease of sugar cane. Some facts relative to the importance of the discovery of the "morbid" cause. Published privately with 2 color plates by author, New York, 1919. 
Gives symtoms and effect of the disease. Claims to have discovered the great secrets of cause and control.

\section{Valleau, W[illiam] D[orney], \& Johnson, E[dward] M[arshall]}

The relation of nitrates to tobaceo frenching. Science. n.s. 64:

278-279, 1926.

Frenching which was for a time considered the same as mosaic is caused by soil conditions. It is not infectious.

\&

Commercial tobacco and cured leaf as a source of mosaic disease in tobaceo. Phytopathology 17(8):513-522, 1927. (Trop. Agric. (Trinidad) 4:135, 1127.)

The virus from dry tobaceo 16-31 years old was active when inoculated into growing plants. The disease was reduced by having the laborers use steam sterilized tobacco.

$\&$

The effect of a strain of tobaceo on the yield and quality of burley leaf tobacco. Phytopathology $17(8)$ : 523-528, 1927.

Losses due to the disease. The author reports two types of mosaic and gives the results of field studies on losses.

Tobaceo frenching-A nitrogen deficiency disease. Kentucky Agric. Expt. Sta. Bull. 281, 1927.

This disease is frequently mistaken for mosaic.

$$
\&
$$

Observations and experiments on the control of true tobacco mosaic. Kentucky Agric. Expt. Sta. Bull. 280 : 145-174, 1927.

The disease is found in the seed beds. It overwinter in horsenettles, ground cherries and in cured tobacco. It is transmitted by the men chewing diseased tobacco and spitting in the seed beds.

\&

Some virus diseases of tobaceo in Kentucky. Phytopathology (Abstract) 18(1) : 132-133, 1928.

\&

Weed control and the potato virus problem. Amer. Potato Journ. 5(9) : 257-259, 1928.

Experiments and observations on the control of true tobacco mosaic. Phytopathology (Abstract) 18(1): 132, 1928.

Peach yellows and potatoes. Plant Disease Reporter 12(9): 102-103, 1928.

Brief mimeograph note giving the relation of peach yellows and potato virus diseases. 
Tobaceo mosaic control in Mexico. Phytopathology 19(9): 880, 1929.

The author believes that bulk heating inactivates the virus.

The viruses concerned in rugose mosaic of Irish Cobbler potatoes and the weed host problem. Phytopathology (Abstract) $20(1): 135,1930$.

\section{\& Johnson, E[dward] $\mathbb{I}[$ [arshall]}

The relation of some tobacco viruses to potato degeneration. Kentucky Agric. Expt. Sta. Bull. 309:475-507, 1930.

The authors give the result of a large number of inoculations and descriptions of the symptoms of virus disease which may be summarized as follows: 1.-A description of a tobaceo disease called veinbanding. 2.-Irish Cobbler potato plants healthy or diseased, appear to always possess a virus which produces necrotic and chlorotic ring and line patterns, in tobaceo. 3.-The mosaic virus and interveinal mosaic virus from Irish Cobbler potatoes, and rugose mosaic virus from Green mountain potatoes produces spot necrosis in tobacco. 4.-A mixture of healthy potato and veinbanding viruses produced a spot necrosis in tobacco which is the same as that produced by the rugose mosaic virus of potatoes. 5.-Cucumber mosaic virus causes a mosaic in potatoes. There appears to be three strains. 6.-Ringspot virus of tobaceo is different from the necrotic ring produced by healthy potato virus. 7.-Three strains of each virus produce a rugose mosaic. 8.- Viruses from weeds appear to be important factors. 9.- Myzus persicae rarely if ever transmitted healthy potato virus.

\section{$\&$}

Some possible causes of streak in tomatoes. Phytopathology $20(10)$ : 831-839, 1930 .

A study of tomato streak and tobaceo mosaic diseases. \&

The viruses concerned in a natural epiphytotic of streak in tomatoes. Phytopathology 21(11) : 1087-1089, 1931.

A brief paper on an outbreak of tomato streak in the greenhouse. The author concludes experiments which demonstrated that the streak in tomatoes and necrotic mosaic in tobaceo resulted from a mixture of tobacco and potato.

A virus disease of plum and peach. Kentucky Agric. Expt. Sta. Bull. 327 : 89-123, 1932.

The author describes and discusses a virus disease of plum and peach. Gives the history of the disease, budding experiments, discusses the patterns and plum virus; spread of the virus budded trees and the spread of similar virus diseases of the apple and rose. At the end gives suggestions for eradication of the virus. 
Seed transmission and sterility studies of two strains of tobaceo ringspot. Kentucky Agric. Expt. Sta. Bull. 327:43-80, 1932.

The most severe disease in Kentucky. There are two types, the green and the yellow. The yellow is distinct from the Aucuba mosaic of potato. Both are carried in the seed. Ring-spot has been reported on Jimson, cantaloupe. Petunia, sweet clover, Physalis sp., Solanum carolinenses and cucumber. The pods produce a small number of seed and the pollen grains are smaller than normal.

A virus disease of Delphinium and tobaceo. Kentucky Agric. Expt. Sta. Res. Bull. 327: 81-88, 1932.

The author reports a virus disease on the garden varieties of Delphinium transferable to tobaceo. He also states that the virus under study appears to affect plants in 3 families, Ranunculaceae, Solanaceae and Cuourbitaceae and in 2 orders; Ranunculales and Campanulales of the flowering plants.

Two seed-transmitted ring-spot diseases of tobacco. Phytopathology 22(1): 29, 1932.

Two ring-spot diseases, (a) green patterns, (b) green \& yellow. Both are transmitted by the seed.

\section{\& Johnson, E[dward] M[arshall]}

Tobaceo diseases in Kentucky. Kentucky Agric. Expt. Sta. Bull. 328:109-154, 1932.

A popular publication giving descriptions of the common diseases, including the most common virus diseases.

Vanha, J. V.

Die Krausel-oder Hollkrankheit der Kartoffel, ihre Ursache und Bekämpfung. Monatschefte fur Landwirtschaft, Jahrg. $3(9): 268,1910$.

Venkata Rao, II. G.

A preliminary note on the leaf curl mosaic disease of Sandal. Indian Forester 49(12) : 772-777, 1933.

Description of this new disease of Santalum album reported from Mysore (India) which the author named "leaf-curl mosaic". Transmissibility studies were conducted which the author describes. The author found that leaf-curl mosaic spreads more rapidly than spike.

\section{Vanterpool, T[homas] C[lifford]}

The stripe or streak disease of tomato in Quebec. Quebec Soc.

Protect. Plants. Ann. Rpt. 1923-24, 16: 116-123, 1924.

A description of the disease. 
Streak or winter blight of tomato in Quebec. Phytopathology 16(5) : 311-331, 1926.

A report of studies which show that this disease is caused by a virus.

\section{Varadaraja Iyengar, A. V.}

Contribution to the study of spike-disease of sandal (Santalum album Linn). II Journ. Indian Inst. Sci. Ser A. 11: 97-109, 1928.

Contribution to the study of spike-disease of sandal (Santalum album L.). Part XV. The role of plant acids in health and disease. (n. d.).

Leaves from healthy plants contain more malic and oxalic acids than those from diseased plants. The reverse is true for succinic acid. The diseased plants contain more phosphates than the healthy plants. Carbon dioxide production is greater for diseased than healthy plants. The reverse is true for shoots that have been cut from the plant.

Vasters, J.

Untersuchungen uber Blattroll-und mosaikkrankheit der Kartoffel. (Investigations on leaf roll and mosaic disease of potatoes. Pflanzenban, 4:211-214, 1928.

Vaughan, $\mathbf{E}$. $\mathbf{X}$.

Transmission of the crinkle disease of strawberry. Phytopathology 23(9) : 738-740, 1933.

Report of studies of the Oregon Agricultural Experiment Station to determine the nature of the infective principle in strawberry crinkle and its mode of transmission.

\section{Vélez, Ramón}

El mosaico del tabaco (Tobacco Mosaic). Rev. Agric. Puerto Rico. 10:25-26; 1923.

A brief popular discussion.

Venkatarama, Ayyar, K. R.

Is spike disease of sandal (Santalum album) due to an unbalanced circulation of sap? Indian Forester 44:316-324, 1918.

A criticism of Hole's paper in Indian Forester 43: 430-443 (1917). Gives evidence that the disease is not caused by fire and not due to unbalanced circulation of sap.

Venkatraman, T. S.

Report of the Government Sugar-Cane Expt. Sta. Sci. Rpt. Agric. Res. Inst. Pusa 1924-25: 142-151, 1925. (Rev. Appl. Mycol. 5 : 251, 1925.) 
Mosaic of sugar cane may have been present in India for some time without being recognized.

\section{\& Thomas, $\mathbf{R}$.}

A leaf adaptation conductive to mosaic resistance in the sugar cane. Agric. Journ. India. 23(1):56-57, 1928.

The authors advance the theory that numerous trichomes which protect the leaves from the insect vectors are factors in resistance.

\section{Verhoeven, W[ilhelm] B[oudewijn] L[eenwenburg]}

Plantenkiekten, waarmede rekening moet worden gehouden bij de veldkeuring. (Plant diseases which should be considered in field inspections.) Tijdschr. Plantenz. 26:149-159, 1920.

\section{Verplancke, G[ermain]}

A propos des maladies de dégéréscence de la pomme de terre. (About the disease of degeneration of the potato.) Ann. Gembloux, Brussel 33 : 443--449, 1927.

Quelques données nouvelles sur les maladies á virus filtrants. (Some new data about the filterable virus diseases.) Ann. Gembloux, Brussel 34:121-135, 1928.

Les maladies á virus filtrants de la Betterave. (Beet disease caused by filterable viruses.) La Sucrerie Belge 49(7) :121127, 1929. (Rev. Appl. Mycol. 9: 355, 1930.)

List of three virus diseases of sugar beet. 1.-Curly top carried by Eutettix tenella. 2.-A similar disease in Czechoslovakia which is supposed to be transmitted by Cicadula sexnotata and 3.-A similar disease in Belgium which is supposed to be transmitted by Myzus persicae.

Une maladie á virus filtrant des Anthurium. (A filterable virus disease of Anthurium). Comptes Rendus Soc. de Biol. 103 (7) : 524-526, 1930. (Rev. Appl. Mycol. 9:388, 1930. Soc. Bot. France, Ann. Bull. $1930: 246$ ).

Contribution á l' étude histologique et cytologique d' une maladie de la pomme de terre, appelée en Amerique "spindle tuber." (Contribution to the histological and cytological study of a disease of the potato called spindle tuber in America.) Acad. Roy. Belgique C., Sci. Mém. Coll. in 8, $11: 1-42,1930$.

The nuclei are sometimes lobed and sometimes contain more than one nucleolus. $\mathrm{X}$-bodies and striated material were present. 
Etude histologique et cytologique des paries aeriennes de la pomme de terre atteinte de spindle tuber. (An histological and eytological study of the aerial parts of the potato attacked by spindle tuber.) Bull. Soc. Roy. Bol. de Belg. 64 (1) : 128-176, 1931.)

The author continues studies which he started in the United States. He found a modification of the tissue of the aerial parts of the diseased plants.

Les maladies de dégénérescence de la pomme de terre. Journ. Soc. Centr. Agr. Belgique 11(6) : 138-170, 1931.

Etude histologique comparée de tubercules sains, allongés et normaux et de tubercules atteints de "Spindle tuber". (Comparative histological studies of sound elongated and normal tubers and those attacked by the "spindle tuber". La Sucrerie Belge 49(7):121-127, 1931. (Bull. Soc. Roy. Belge $63(2): 138-148,1931$.)

Experiences sur la transmission des maladies dégénérescences de la pomme de terre. Ann. Gamblaux 37(2):65-69, 1931. (11) : 345-349, 1144-1146, 1932.

This paper gives the results of transmission studies.

Etude histologique comparée de tubercules sains, allongée et normaux et de tubercules atteints de "spindle tuber". Bull. Soc. Roy. Bot. Belg. 63(2) : 138-144, 1931.

Une maladie á virus filtrant de Pelargonium Zonale. (A disease of Pelargonium Zonale due to a filterable virus.) Bull. Ce. Sci. Acad. Roy. de Belgique, Ser. 5. Vol. 18(3) : 269-281, 1932.

Experiences sur la transmission des maladies de dégénérescence de la pomme de terre. (Experiences on the transmission of the diseases of the degeneration of the potato.) Ann. Gembloux $39(1)$ : 12-23, 1933.

Description of result obtained in experiments on virus diseases of potatoes. 
Hotes nouveaux des maladies \& virus filtrants de la Betterave. (New hosts of the beetroot diseases due to filterable viruses.) Bull. Soc. Roy. Bot. Belg. ser. 2 15(2) : 137-147, 1933.

Report of the author's cross-inoculation experiments with yellows and mosaic viruses of beet on 60 plants, most of which are common weeds.

Étude comparative de pommes de terre d' origines diverses. II. Résultats des expériences faites en 1932. (Comparative studies of potatoes of different origines. II. Results of Experiments done in 1932.) Bull. Inst. Agron. \& Stat. Rech. de Gembloux 2(1): 45-73, 1933.

The degeneration diseases present were leaf roll, mottling, mild mosaic, rugose mosaic, erinkle mosaic, aucuba mosaic and streak. Results of studies are given in full details and tabular form.

Les viroses de la betterave. (The viroses of the beet.) Sucrerie Belge, 53(1) : 2-10, 1933.

Verret, J. A., \& Verret, D. F. C.

Losses caused by mosaic in H-109 plant cane. The Hawaiian Plant. Rec. 33(3) : 362, 1926.

Losses from mosaic. Kohala Sugar Co. Expt. No. 1. Hawaii Plant. Rec. 31 : 244-245, 1927.

Verteuil, J[oseph de], \& Brunton, I. A.

Sugar cane experiment 1919-1922. Trinidad \& Tobago Dept. Agric. Bull. 19(4) : 188-214; 20(2-4) : 65-109. 1922.

\section{Verwoerd, Len}

Two diseases of the tomato mosaic and early blight. Farming So. Africa, 3: 1167-1169, 1928.

On two eases of recovery from a mosaic disease tomato plants Lycopersicum esculentum. Ann. Appl. Biol. 16(1):34-39, 1929 .

Six cuttings from a diseased plant were rooted. Two of them did not develop symptom and the juice from them did not cause the disease in other plants.

\section{Veve, Rafael A.}

The eradication of sugar cane mosaic in Fajardo. Puerto Rico Ins. Expt. Sta.. Cire. 33:52-55, 1920. 
La represión del matizado en Fajardo. (Mosaic eradication in Fajardo.) Rev. Azucarera \& Agric. Puerto Rico 1:96-98, 1921.

The efficiency of "roguing" method for the eradication of mottling disease. Louisiana Planter 69(2) : 30, 1922.

The disease was reduced from 0.5 to $0.002 \%$. Believes that roguing ean be practiced where the percentage of disease is less than $15 \%$.

Cane mottling eradication. Facts About Sugar 15(4) : 78, 1922. See proceeding annotation.

Overcoming the mosaic disease at Fajardo. Facts About Sugar $18(20): 468,1924$.

Mosaic has been overcome by roguing.

Vibert

Observations relatives a L' influence qu' exerce la greffe sur le sujet. (Observations about the influence that the graft exercise on the stock.) Journ. Soc. Imp. \& Cent. Hort. (France) 9:144-145, 1863.

In this paper the author demonstrates the transmissibility of rose mosaic.

Vidal, L. F.

El mosaico de la caña de azúcar. (Mosaic of sugar Cane.) Tipografía Cervantes, San P. de Macorís, Dominican Rep. 44 p. (Facts About Sugar $26: 503,1931$.

A popular textbook.

Villamin, V.

Mosaic-immune variety of sugar-cane. Sugar 5:345, 1923.

Villillo, G.

(Filterable virus) Ztschr, Infektionskrank, u. Hyg. Haustiers, 9(6) : 433-479, 1911.

\section{Vincent, $\mathbf{C}$ [hester] $\mathbf{L}[$ eon]}

Potato breeding problems. Proc. 16th Ann. Meeting Potato Assoc. America. 1929-30:63-69, 1930. (Rev. Appl. Mycol. $9: 550,1930$.)

Results of efforts to develop a variety free from mosaic.

\section{Vinson, C[arl] G[eorge]}

Precipitation of the virus of tobaceo mosaic. Science n.s. 66 (1711) : 357-358, 1927. 


\section{\& Petre, $\mathbf{A}[$ ndrew] $\mathbf{W}[$ illiam]}

Mosaic disease of tobaceo. 1-Progress in freeing the virus of accompanying solids. Bot. Gaz. 87(1) :14-38, 1929. (Contr. Boyce Thompson Inst. 1:479-503, 1929.)

This paper gives the results of experimental work for the purpose of freeing the active agent from all other material. The authers report that the virus is precipitated by an aqueous solution of safranin.

Progress in freeing the virus of mosaic disease of tobacco from accompanying solids. Phytopathology (Abstract) 19(1) : 107108, 1929.

Mosaic disease of tobacco. II. Activity of the virus precipitation by lead acetate. Contr. Boyce Thompson Inst. 3(1) : 131146, 1931.

The author deseribes a new method and gives the results of experimental work.

\section{\& Gildeham, Edgar J.}

Comparison of juice from diseased and healthy tobacco plants. Phytopathology (Abstract) 22(1) : 29, 1932.

Decomposition of the safranin precipitate of mosaic virus of tobacco. Phytopathology (Abstract) 22(1) : 29, 1932.

Mosaic diseases of tobacco: 5-Decomposition of the safraninvirus precipitate. Phytopathology 22(12) : 965-975, 1932.

This paper gives the results of experimental studies for securing a rapid method for the purification of virus preparation.

Virus diseases of plants. Missouri Agric. Expt. Sta. Bull. 310: 41, 1932.

Brief notes on experimental work in progress to determine the nature of the virus of solanaceous plants.

Further purification of the virus of tobaceo mosaic. Phytopathology (Abstract) 23(1):35, 1933.

Purification of the virus of tobaceo mosaic. Phytopathology (Abstract) 24(1): 20, 1934.

Possible chemical nature of tobacco mosaic virus. Science n.s. $79(2059)$ : 548-549, 1934. 
Brief article, discussing, Lojkin and Vinson, Barton-Wright and Me Bain, and Caldwell's previous work on the subject. Comparison of results obtained under each condition.

\section{Vochting, Hermann von}

Ueber die keimung der kartoffelknollen. Bot. Ztg. 1, 60:87114, 1902.

\section{Vogel, Irving Henry}

Leaf-roll and mosaic of potatoes. Proc. New York State Potato Assoc. p. 21-24, 1918.

\section{Voges, E[rnst]}

(The history of potato leaf-roll.) Fühling's Landw. Ztg. 61 (16) : 542-552, 1912.

\section{Volk, A[lfred]}

Das diesjährige starke Auftreten des Mosaikkrankheit (Gelbflegheit) des Sinates. (The current year's widespread occurrence of mosaic disease (Yellow spotting) of spinach.) Inst. fur Pflanzenkrankh. der Landw. Hochschule. Bonn. Poppelsdorf. 3 p., 1929. (Rev. Appl. Mycol. 9:428, 1930.)

A severe outbreak of mosaic on spinach. The disease is transmitted by Macrosiphum pisi, Aphis fabae, (A, runisit) Myzoides (Myzus) persicae.)

Einflüsse des Bodens, der Luft des Lichtes auf die Empfanglichkeit der Pflänzen fur krankheiten. Phytopath. Zietschrift. $3(1): 9-16,1931$.

\section{Volkart, A[lbert]}

Abvan und Viruskrankheiten. (Degeneration and virus diseases.) Land. Vorträge 55 p., 1933.

Diseussion of the ecological theory of degeneration of potato with special reference to $\mathrm{H}$. Morstatt, Merkenschlager and other hypothesis. The author declares that potato degeneration as observed in Switzerland is entirely to be attributed to the influence of virus diseases.

\section{Wager, V. A.}

Tomato diseases. 1-Leaf spot; 2-Blossom rot, 3-Mosaic, 4 -Canker of bacterial spot, 5-Bacterial wilt. Farming So. Africa, 2:133-136, 185-190, 235, 289-290, 1927; 2:601$602,1928$.

\section{Wagner, II.}

Variétés de Pomme de terre susceptibles d'être cultivés avec succés en des altitudes entre 1,000 et 2,000 metres. (Potato 
390 THE JOURNAL OF AGRICULTURE OF THE UNIVERSITY OF P. $R$.

varieties susceptible of being cultivated with success at an altitude between 1,000 and 2,000 meters.) Comptes Rendus Acad-Agric. France 15(21) : 763-765, 1929.

\section{Wahl, $B$ [runo]}

Bericht über die Tätigkeit der Budensanstalt für Pflanzenschultz in Wien in den Jahren 1921 bis 1923. (Report on the Federal Institude for Plant Protection in Vienna during the year 1921 to 1923.) Ztchrs. Landw. Ver. in Deutsch-Ostr. p. 48, 1924.

\section{Waite, $\mathbf{M}$ [erton] $\mathbf{B}$.}

Peach yellows and frost injury. Science n.s. 31(803) : 798-799, 1910.

Brief but very comprehensive note defining these two troubles of frequent confusions.

The peach yellows group of peach disease. Calif. Dept. Agr. Mo. Bull. 19(7): 484 488, 1930.

Brief popular description of peach yellows, peach rosette, little peach and phony peach disease.

\section{Wakefield, E[lsie] M[aud]}

Mosaic disease of cane. Sugar, 23:500-501, 1921.

Mosaic disease of plants. West Indian Bull. 18:197-206, 1921.

\section{Wakker, Jan $\mathbf{H}$ [endrik]}

Gele Strepenziekte. (Yellow stripe disease.) Archief voor de Java Suikerind, 1: 4, 1894.

Die indirecte Bekämpfung der Serehkrankheit des Zuckerrohres auf Java. 66:1-7, 1896.

tian]

\section{\& Went, $\mathbf{F}$ [riedich] A[ugust] $\mathbf{F}$ [erdinand] $\mathbf{C}[$ hris-}

(A review of the diseases of the sugar-cane in Java, I.) Med. Proefsta. East Java. N. Ser. No. 22, p. 11, 1896.

De Ziekten van het Suikerriet op Java. (Sugar cane disease in Java.) Leiden. p. 166-169, 1898.

\section{Walbach, $\mathbf{S}$ [imeon] $\mathbf{B}$ [urt]}

The filterable virus summary. Journ. Med. Res. 27(1):1-25, 1912. 


\section{Waldmann, 0. Pyl, G.}

Über unsishtbare krankheitserreger. 1-Der Stand der Virusfoschung. 2-Über die moghichkeit einer chemischen Bearbeitung des Virus problems. 3-Die Kunsthche Vermechrung netravisibler Krankheitserreger. Naturwissenschaften 20: 129-134, 150-153, 1932.

\section{Walker, IMIarion] $\mathbf{N}$ [ewman]}

Physalis and cucurbit mosaic intertransmissible. Phytopathology (Abstract) 14(1):56, 1924.

The mosaic disease of Nicotiana glutinosum not distinct from tobacco mosaic. Phytopathology (Abstract) 14(1): 57, 1924.

Studies on the mosaic disease of Nicotiana glutinosa. Phytopathology 15(9) : 542-543, 1925.

The author gives a brief review of the literature and results of inoculation work. He says: "The mosaic disease on tobacco is transmissible to $N$. glutinosa and the mosaic disease on $N$. glutinosa is transmissible to tobacco"'. Tomatoes are susceptible to the same disease.

The Relation of Certain species of Physalis to overwintering of the mosaic diseases of cucumber. Phytopathology 15(12): 733-744, 1925.

The author gives evidence that the cucumber virus overwinters in Physalis pubescens. He transmitted the disease by inoculation to $P$. subglabrata and $P$. heterophylla.

A comparative study of the mosaic disease of cucumber. Tomato and Physalis. Phytopathology 16(7) : 431-458, 1926.

A study in the variations of the reactions of host plants to extracts from different mosaic plants.

\section{\& Stahl, C[orwin] F[loyd]}

Certain grass hosts of the corn aphid considered in relation to their oceurrence in Cuba. Trop. Plant Res. Foundation Bull. 5 : 3-14, 1926. (Rev. Appl. Mycol. 5: 318, 1926. Rev. Appl. Ent. Ser. A. 15: 379, 1926.)

This paper gives the results of studies of sugar cane mosaic on other hosts.

Walker, II. N.

Occurrence of watermelon mosaic. Phytopathology 23(9) : 741744, 1933. 
Report of the occurrence of watermelon mosaic in Florida. The writer gives a description of the disease and its behaviour. Aphis gossypii appears to be the possible insect vector. This is apparently the first record of the spontaneous occurrence of mosaic in watermelons.

Wallace, G. B.

Report of the Mycologist. Tanganyika Territory Dept. Agr. Ann. Rpt. 1932: 76-80, 1933.

The author reports that the most destructive disease of sesame is a leaf curl probably caused by a virus.

Wallman, F.

Bacteriophagie et processus similares mosaïque des plantes. (Bacteriophage and similar processes mosaic diseases of plants.) Bull. Inst. Pasteur 26(1):1-14, 1928.

\section{Wann, F[rank] B[urkett]}

Chlorosis yellowing of plants; cause and control. Utah Expt. Sta. Cire. 85, 11 p. 1930.

\section{\& Blood, H[ebert] L[oren]}

Biochemical changes accompanying curly top of tomatoes. Phytopathology (Abstract) 23(11): 929, 1933.

Waters, C. E.

Witches' broom on the locust. Plant World 1:83-84, 1898.

Watson, H. E. et al

Proceedings of the conference on the spike-disease of sandal held at 11 A. M. on Monday, the 7th July, 1930 at the Indian Institute of Science, Bangalore, Indian Forester 57(5):215233, 1931.

Reports of many investigators of the studies on various phases of this virus disease.

Watt, R. D., Goddard, E. J., \& Osborn, J. G. B.

Investigations of "bunchy top" disease of bananas. Queensland Agric. Journ. 21(4) : 263-275, 1924.

A very comprehensive paper on our knowledge of the disease up to that time.

\section{Waugh, John G., \& Vinson, Carl G[eorge]}

Particle size of the virus of tobacco in purified solutions. Phytopathology (Abstract) 22(1):29, 1932.

Webb, R[obert] W[illiam], Leighty, C[lyde Evert], Dungan G[eorge] H[arlan], \& Kendrick J[ames] B[lain]

Varietal resistance in winter wheat to the rosette disease. Journ. Agric. Res. 26(6) : 261-270, 1923. 
The results of studies showing that this disease can be controlled by the use of resistant varieties.

Certain factors influencing the development of the mosaic disease of winter wheat. Phytopathology (Abstract) 17(1): 41, 1927.

Soil factors influencing the development of the mosaic disease in winter wheat. Journ. Agric. Res. 35(7) : 587-614, 1927.

This paper gives the effect of temperature and moisture on the development of both the host and the disease.

Further studies on the soil relationships of the mosaic disease of winter wheat. Journ. Agric. Res. 36(1) : 53-76, 1928.

This paper gives the results of studies showing that the active agents exist in the soil.

\section{Weber, G[eorge] F[rederick]}

Mosaic disease of sweet potato. Phytopathology (Abstract) $13(1): 42-43,1923$.

\section{\& West, $\mathbf{E}[\mathrm{rdman}]$}

Diseases of sweet potatoes in Florida. Florida Agric. Expt. Sta. Bull. 212, 40 p., 1930.

Popular notes given sweet potato mosaic diseases.

Mosaic disease of vegetable plants. Florida Agric. Expt. Sta. Press. Bull. 446, 2 p., 1932.

Popular.

Wedkeworth, H[erman] H[amilton], \& Anders, C. B.

Value of certified Irish potato seed in Mississippi. (Mosaic)

Mississippi Agric. Expt. Sta. Circ. 60, 4 p., 1925.

Popular, contains data on yield.

Effect of mosaic on sweet potato yields. Missouri State Plant Bd. Quart. Bull. 6(3):11-12, 1926.

Degeneration diseases of the irish potato in Mississippi. Mississippi Agric. Expt. Sta. Bull. 258. 11 p. 1928.

The author gives a description of mosaic, leafroll and spindle tuber. Also the effects on production and method of control by the use of certified seed. 


\section{Weimer, J[ames] L[e Roy]}

Further evidence of the non-transmissibility of the so-called: sweet potato mosaic. Phytopathology (Abstract) 16(1):74, 1926.

Alfalfa mosaic. Phytopathology (Abstract) 21(1):122-123, 1931.

Studies on alfalfa mosaic. Phytopathology 24(3):239-247, 1934.

Deseription of a transmissible virus disease of alfalfa, of the mosaic type. The insect vector used in transmitting the disease was the pea aphid.

\section{Weiss, $\mathbf{F}$ [reeman] A[lbert]}

A summary of the important contributions to potato pathology, which have appeared in foreign periodical literature in the past year. Potato Assn. Amer. Proc. 14:215, 218-225, 1927.

\section{\& IVIC Whorter, Frank P[aden]}

Pacific Coast survey for rose mosaic. U.S.D.A. Plant Disease Reporter 14(20): 203-205, 1930. (Mimeographed).

\section{Wellensiek, S[usan] J[acobus]}

Met een Hollandew samenvatting de physiologie der knolvorming bij de aardapple. (The physiology of tuber-formation in the potato plant.) Overgedrukt uit de Mededeelingen van de Land Bouwhoogeschool. Deel 33, 1929.

The author planted tubers in wet sand and kept them in the dark. The sprouts were removed as soon as formed. The author describes seven types of tuber formation as follows,-(1) Normal tuber-formation.-(2) aerial tuber-formation,-(3) tuber formation during storage in the light,-(4) tuber formation during the storage in the dark,(5) tuber-formation on dried mother tubers,-(6) premature tuberformation after planting,-(7) Oortwijin Botje's case of tuber-formation are compared as to their mode of origin, they all can be ascribed to an increase of the concentration of food-substances. However, this increase may be directly due to photosynthesis (above types 1, 2, and perhaps 3), indirect absolute due to loss of water (types 4, 5 and 6, probably also type 3 ) or indirect relatively due to loss of a certain substance (type 7).

De invlved van poottijd en rijafstand op de verspreiding van Aardappelvirosen. (The influence of planting time and row distance on the spread of potato viruses.) Landbonwkundig 
Tijdschr., 41(497) : 641-648, 1929. (Rev. Appl. Mycol. 9: 331, 1930.)

The results are tabulated and gives much valuable information.

\section{Wallington, $R$ [ichard]}

Degeneracy of the potato. Rpt. Second, Ann. Meeting Minnesota Potato Growers Ass'n, 1917.

The uselessness of hill selection under conditions where rapid degeneration or running-out is prevalent. Proc. Amer. Sci. 1919 : 175-179, 1920.

Wellman, F. L.

Control of celery mosaic by eradicating of the wild host Commelina nudiflora. Phytopathology, 22(1):30, 1932. Science 76: 390-391, 1932.)

The disease is not carried in the seeds but persists in C. nudiflora. The vector is Aphis gossyppi.

Wennink, C. $\mathbf{S}$.

De gevolgen der bladrolziekte bij aardappelen. (Control of leaf-roll of potatoes.) Tijdschr. Plantenz. 24(1):1-4, 1918.

The results of experiments which support Quanjer's statement that disease-free potatoes ean be produced by seed selections and growing in non-infested soil.

\section{Went, F[riedich] A [ugust] F[erdinand] $\mathbf{C}$ [hristian]}

De serehziekte. Arch. Java-Suikerind. 1:425-472, 1893.

De serehziekte. In Wakker en Went. De ziekten van het Suikerriet of Java p. 76-98, 1898.

\section{Werner, $\mathrm{H}$ [arvey] O[scar], \& Howard $\mathrm{R}$ [obert] $\mathrm{F}$ [rancis]}

Seed potato investigations. Nebraska Agric. Expt. Sta. Res. Bull. 24, 58 p., 1923.

Field studies on the effects of degeneration diseases and methods of control.

Spindle-tuber, the cause of "run out" potatoes. Nebraska Potato Imp. Assoc. Ann. Rpt. 6: 57-79, 1924.

Relation of environment to spindle-tuber symptoms. Proc. 1924 Ann. Meeting Potato Ass'n Amer. 11: 102-106, 1925.

A discussion of facts brought out as a result of field experiments. 
The spindle-tuber disease. On cause of "run-out" of seed potatoes. Nebraska Agric. Expt. Sta. Bull. 207, 21 p., 1925. This paper gives the distribution of the disease, its effect on yield and quality, symptoms, transmission, rate of increase and methods of control.

The spindle-tuber disease as a factor in seed potato production. Nebraska Agric. Expt. Sta. Res. Bull. 32:4-128, 1926.

A very extensive paper giving symptoms, commercial consideration, geographical distribution, influence of enviroment and transmissiun.

Identifying spindle tuber in the field. Amer. Potato Journ.. 4(8) : 89, 90, 1927.

Relation of time of roguing to the spread of spindle tuber in seed potato plants. Phytopathology 19(11) : 1045-1049, 1929. (Rev. Appl. Mycol. 9:263, 1930.)

A discussion of control by roguing.

Effect of variable conditions within a field containing spindie tuber plants upon the seed value of the potatoes produced. Amer. Potato Journ. 6(6) : 168-170, 1929.

\section{Werth, $\mathbf{E}[\mathrm{mil}]$}

Zur Klimatologye, Pflanzengeographie und Geschichte des Europaischen Ackerbanes. (On the climatology, plant geography and history of european agriculture.) Ber. d. Deutsch. Bot. Gesell, 47:34, 1929.

\section{Wessels, P[hilip] H[enry], \& Hartwell, B[urt] L[aws]}

Viability and composition of "seed" potatoes as affected by climatic conditions and by various other factors. Journ. Amer. Soc. Agron. 19:761-780, 1927.

This paper contains some data on the "running out" or "deterioration" of potatoes.

\section{Westerdijk, Johanna}

Die Mosaikkrankheit der Tomaten. (Mosaic diseases of tomato.) Meded. Phytopath. Lab. Willie Commelin Scholten, Amsterdam, 1:1-20, 1910.

Gives results of studies on heredity, light and transmission. Could not infect tobaceo with tomato mosaic or tomato with tokaceo mosaic. Carried in the seed. 
Die mosaikkrankheit der kartoffelplanze. (Mosaic disease of the potato plant.) Jahresbericht de verreiningung für angewandie Botanik 14:145-149, 1916.

\section{Weston, William H[enry] Jr.}

Report on the plant disease situation in Guam. Guam Agric. Expt. Sta. Report 1917 : 45-62, 1918.

Reported a yellowing and dwarfing of corn.

\section{Whetzel, $\mathrm{H}$ [erbert] $\mathrm{H}$ [ice]}

Report of the pathologist for the period June 10 to Dec. 1921, pp. 30-64. Bermuda, Bd. and Dept. Agric. Reports. 1921: 30-64, 1922.

The seed potato situation. Bermuda Dept. Agric. Bull. 1922: 2-4, 1922.

\section{Whipple, Orville B[laine]}

Degeneration in potatoes. Montana Agric. Expt. Sta. Bull. 130, 29 p., 1919.

Popular discussion. Gives the result of five years' field studies on these diseases.

\section{White, Richard P [eregrine]}

An infectious chlorosis of roses. U.S.D.A. Plant Diseases Reporter 12(4) : 33-34, 1928.

Early record and description of the disease.

Field control of rose diseases. Phytopathology (Abstract) 20 (1) : 130-131, 1930.

(Diseases of the following ornamental plants: China aster. Delphinium or larkspur, iris, peonias, roses, sweet peas and tulips. New Jersey Agric. Expt. Sta. Circ. Nos. 234, 237, 239, 241, $243 \& 244,1931$.

Popular notes on virus diseases of these plants.

Chlorose of the rose. Phytopathology, 22(1) : 53-69, 1932.

The author describes different types of chlorosis with special attention to the virus type which attacks Rosa manetti, $R$. multiflora $R$. odorata and some varieties.

\section{Whitehead, T[athan]}

A possible cause of "spike" in sandal. Indian For. 42:247, 1916. 
Leaf curl and mosaic of potatoes and their relation to deterioration in yield. Univ. Col. No. Wales, Bangor, Agric., Rpt. Exts., 1920-21: 48-50, 1921.

Transmission of leaf-roll of potatoes in N. Wales during 1921. Rpt, Int. Conf. Phytopath. and Econ. Ent. Holland, P. 147149, H. Veenman \& Sons. Wageningen, 1923.

The results of studies showing that this disease can be transmitted through the roots.

Plant virus diseases. Brit. Assoc. Adv. Sci. Rpt. (Abstract) $91: 493,1923$.

Potato leaf-roll and degeneration in yield. Ann. Appl. Biology $11(1)$ : 31-41, 1924.

A progress report on methods of transmission and treatments.

Some experiments on potato leaf-roll transmission in Wales. Welsh Journ. Agric. 1(1-10) : 184-188, 1925.

Experiments on the control of potato leaf-roll. Welsh Journ. Agric. 3: 169-180, 1927.

Phloem-necrosis and starch accumulation in potato leaf-roll. Rep. Brit. Assoc. p. 388-389, 1927.

\section{\& Currie, J. F.}

Potato leaf-roll. Development of secondary symptoms in the year of infection. Scottish Journ. Agric. 12(2) : 214-215, 1929. Brief preliminary notes on the subject. , \&

Development of secondary symptoms in the year of infection. Journ. Min. Agric. Gt. Brit. 37: 159-163, 1930.

Results of experiments conducted by the authors. It is suggested that the presence of secondarily infected plants in a crop will afford a reliable index of the degree of infection of the seed-stock only if it is known that the plants had passed a certain critical stage in growth before aphis infestation occurred.

Transmission of potato leaf-roll. Nature 126(3172):241-242, 1930.

A brief review of transmission by insects. 
Transmission of potato leaf-roll. Nature 125(3165):974-975, 1930.

The author reports Myzus circumflexus as a vector of leaf-roll and Macrosiphum gei as a feeble vector.

A study of the degeneration of certain potato stocks. Ann. Appl. Biol. 17 (3) : 452-486, 1930.

An extensive discussion on the subject giving experimental data.

Respiration of healthy and leaf-roll potatoes. Nature 128 (3240) : 967, 1931.

A brief note in which the author reports a disturbance in the metabolism of diseased potatoes. He does not offer any explanation of: the results at present.

On the transmission of potato leaf-roll by aphids. Ann. Appl. Biol. 18(3) : 299-304, 1931.

Both Myzus circumflexus Buckton and $M$. persicae Sulz are equally efficient vectors of potato leaf-roll. Macrosiphum gei Kock transmitted the disease only once and the author regards this aphid as an open question as vectors.

\& Currie, J. F.

The susceptibility of certain potato variations to leaf-roll and mosaic infection. Ann. App. Biol. 18(4) : 508-520, 1931.

Seven varieties were tested. Mosaic infection was very light; on the other hand infections due to leaf-roll were very heavy. Other valuable data are given.

The physiology of potato leaf-roll. I-On the respiration of healthy and leaf-roll infected potatoes. Ann. Appl. Biol. $21(1): 48-77,1934$.

"A comparative study of the rates of respiration, as measured by the weight of carbon dioxide evolved, has been made with healthy and leaf-roll infected potatoes at all stages in the life cycle, under anaerobic as well as aerobic conditions."

"Except for a short period covering the end of dormancy of the tuber to the first unfolding of the leaves, the infected plant respires at a much higher rate than does the healthy one. This is true also when the conditions of light temperature, and external carbon dioxide approximate to those present in the field.",

"The rate of respiration is not directly related to the presence of virus but rather to the available amount of respirable substrate. Normally the accumulation of such substances in the leaves of leaf-roll plants occurs at a very early stage of development, but can be delayed 
by continuous exposure to light of low intensities. Under these latter conditions the rate of respiration of diseased plants approximates to that of healthy ones."

\section{Wichmann, W.}

Ursache. Verbreitung und Bekämpfung der mosaikkrankheit des Spinats. (Cause, distribution and control of the mosaic disẹase of spinach.) Obst-und Gumüsebau 76(10) :160-161, 1930 .

Brief popular notes on the etiology and control of the mosaic of spinach.

Die Spinatkrankheit, ihre Uräsache, Verbreitung und Bekämpfung. (The Spinach disease, its cause, spreading and fight.) Nassauer Land 112:100, 1930. (Obst. u. Gemuseb. 76:160161, 1930.)

Discussion on mosaic disease.

Die spinatkrankheit am Rheim. (The spinach disease at the Rheim.) Die Umschan 34:451-452, 1930.

\section{Wickens, G. W., \& Carne, W. M.}

Bitter pit in apples. Its occurrence in store in relation to date of picking. Journ. Dept. Agric. W. Australia 2 Ser. 4(3): 354-357, 382-385, 1927.

Account of his conclusions as to the date of picking in relation to the disease. Written before the cause was known.

\section{Wieler, $\mathbf{A}[$ rwed]}

Die grumösen Verstofungen des sereh-kranken suckerrohres. Beit. Wiss. Bot. 2(1) : 29-140, 1897.

Relation of eranberry varieties to the spread of false blossom. Phytopathology (Abstract) 23(1) : 36, 1933.

\section{Wilbrink, G[ertrude], \& Ledeboer, F.}

Bijdrage tot de kennis des gelestrepenziekte (Contribution to the knowledge of the yellow stripe disease.) Arch. Java Suikerindus Neder. Indie Jaarg 18:465-518, 1910. (Reprinted as Meded Proefst. Java Suikerindustrie 2(39) : 443$495,1910$.

Een-Onderzoek naar de verbreiding der gelestrepenziekte door bladluizen. (An investigation of the transmission of yellow stripe disease by green-lice. Meded. Proefst. Java Suikerind. 
30(10) : 413-456, 1922. (Int. Sugar Journ. 25 (295) : 346-451, 1923. Rev. Appl. Ent. Ser. A. 11 : 90, 1923. Rev. Appl. Mycol. 2 : 236-237, 1922.)

The author gives brief history of the disease and states that her observations in Java corroborates those of Brandes in the United States.

Warmwaterbehandeling van stekken als geneesmiddel tegen de serehziekte van het suikerriet. (Hot water treatment for cuttings as a remedy against sereh disease of sugar cane.) Arch. Suikerindus. Nederlan-Indië, Meded. Proefst. Java Suikerindus. No. 1, 15 p., 1923.

Bekämfung der Sereh-krankheit. (Combating the sereh disease.) D. Zuckrindunst. $48: 274,1923$.

Mechanical transmission of sugar mosaic. Proc. Third Congress Internat Soe. Sugar Cane Technologists p. 155-165, 1930.

This experiment indicated that it is possible for sugar cane mosaip to be transmitted by the cutting knives.

\section{Wilcox, Raymond B[oorman]}

Fastern blue-stem of the black raspberry. U.S.D.A. Circ. 227, 12 p., 1922.

A description of a disease which may be due to a virus.

\section{\& Smith Floyd, F[ranklin]}

Transfer of mosaic disease from red to black raspberry. Phytopathology (Abstract) 14(1): 55, 1924.

Observations on masking of raspberry mosaic by high temperature. Phytopathology (Abstract) 16(1): 80, 1926.

False blossom inoculation experiments at Toms River, N. T. 1928-1929, Proc. 60th Ann. Conv. Amer. Cranberry Growers' Asso. p. 11-16, 1930.

The author demonstrated that the false blossom of the cranberry was transmitted by the blunt-nosed leaf hopper (Euscelis striatulus).

Adjustments to cranberry false blossom in New Jersey. Proc. Ann. Conv. Amer. Cranberry Growers' Assoc. 63:7-11, 1477, 1932.

Statistical data of cranberry production in New Jersey from 1884 to 1930 , and the effect of it due to false blossom. 
Wiles, D. R. D.

Sugar cane mosaic disease. Barbados Dept. Agric. Ann. Rpt. 1927-28; 16-18, 1928.

Report of the work during the year in regard to sugar-cane mosaic eradication.

Report of the plant disease inspector for the year 1928-29. Ann. Rpt. Dept. Agric. Barbados for the year 1928-29: 8588, 1930. (Rev. Appl. Mycol. 9: 560, 1930.)

A record of sugar cane mosaic.

\section{Wille, J[ohan]}

Die durk die Rübenblattwanze erzengte krauselkrankheit der Rüben. Arbeiten der Biologischen Reichsanstalt für Landund Forst-wirtschaft 16(1) : 115-167, 1928.

Die Rübenblattwanze Piesma quadrato Fieb. (The beet leaf bug Piesma Quadrata Lieb.) Monogr. Zum Pflanzenschutz, J. Springer, Berlin, 2, p. 116, 1929. (Abs. in Fortsch. der Landw. 4(22): 736, 1929. Rev. Appl. Mycol. 9(3): 153, 1930.)

A study of the beet leaf bug Piesma quadrata (Zosmenus quadratus) a vector of curl on beets, mangolds, spinach and sorrel (Rumex acetosa).

\section{Williams, C[arrington] B[onsor]}

The mosaic disease of sugar-cane in Trinidad. Trinidad \& Tobago Dept. Agric. Bull. 19(1) : 30-37, 1920.

The mosaic disease of sugar cane. Trinidad and Tobago Dept. Agric. Bull. 19(2) : 49-50, 1921.

Sugar-cane pest and disease in Trinidad in 1920. Trinidad and Tobago, Dept. Agric. Bull. 19(3) : 111-112, 1921. (Rev. Appl. Mycol. 1:192-194, 1921.)

A general discussion of the subject.

\section{Wingard, $\mathbf{S}$ [amuel] $\mathbf{A}$ [ndrew]}

Hosts and symptoms of ring spot, a virus disease of plants. Journ. Agric. Research 37(3):127-154, 1928.

The author gives a review of the literature, and the results of inoculation experiments, with a list of susceptible plants and symptoms.

\section{\& Fromme, $\mathrm{F}[\mathrm{red}] \mathrm{D}$ [enton]}

Tobacco ringspot: A virus disease with a wide range. Phytopathology (Abstract) 18(1) : 133, 1928. 
Winter, J. D.

Raspberry mosaic from the inspector standpoint. Minn. Hort. 53 : 33-36, 1925.

Raspberry mosaic. Journ. of Econ. Ent. 22(3) : 486-490, 1929. A discussion of the five groups of the virus diseases of Raspberries.

\section{Wolcott, George N[orton]}

The minor sugar-cane insects of Porto Rico. Journ. Dep. Agric. Porto Rico 5(2) : 5-46, 1921. (Rev. Appl. Ent. ser. A. 10:9698, 1922.)

Annual Report of the Division of Entomology. Puerto Rico Ins. Expt. Sta. Ann. Rpt. 1920-21: 47-49, 1922.

Brief note of the work of the year concerning sugar cane mosaic.

Informe anual de la División de Entomología. Puerto Rico. Ins. Expt. Sta. Ann. Rpt. 1922-23: 33, 1923. Preceding annotation.

El áfido del maíz. Aphis maidis Fich. (The corn Aphids, Aphis maidis Fitch.) Puerto Rico Ins. Expt. Sta. Bull. 32: 43, 1924. Popular note. Description of the insect as vector of sugar cane mosaic.

Los áfidos que afectan a la industria azucarera del Perú. (Aphis that affect the sugar industry in Perú.) La Vida Agrícola (Perú) 5(59) : 877-886, 1928. (Estac. Expt. Agron. Soc. Agrar. Circ. No. 12. 1928 Rev. Appl. Ent. ser. A. 17: 99, 1928.)

Increase of insect transmitted plant diseases and insect damage through weed destruction in tropical agriculture. Ecology 9(4) : 461-466, 1928.

Refers to the passage of Aphis maidis from grasses to sugar cane after cultivation, which is followed by an increase in mosaic.

Mosaic sugar cane in Perú. Science. 69:381, 1929.

Wolf, Frederick $\mathbf{A}$ [dolphus], \& Legman, S[amuel] G[eorge]

Notes on new or little known plant diseases in North Carolina in 1920. North Carolina Agric. Expt. Sta. 43:55-58, 1920. 
Epiphytology of tobaceo mosaic in North Carolina. Phytopathology (Abstract) 21(1) :118, 1931.

Roguing as a means of control of tobaceo mosaic. Phytopathology 23(10): 831-833, 1933.

Advises to practice this system for checking the spread of tobaceo mosaie.

\section{\& Moss, E. G.}

Effect of mosaic of flue-cure tobaceo on yield and quality. Phytopathology 23(10): 834-836, 1933.

The authors found out that the degree of damage of mosaic disease on tobacco is related to the stage of growth at which infection oceurs. The younger the plants the greater the damage. Mosaie seriously reduces the yield and quality.

\section{Wolk, P. R.}

Het nieuwe gezichtspint de serehziekte. (New view point on "sereh" disease.) Culture 30:302-306, 1918.

\section{Wollman, E.}

Bacteriophagie et processus similaires: I. Hérédité en infection? II. Maladies des mosaïques des plantes. (Bacteriophage and similar processes. I. Heredity or infection? II. Mosaic disease of plants.) Bull. Inst. Pasteur 26(1):1-14, 1928.

\section{Wolzogen-Kühr, C. A. H. von}

Onderzoekingen aangaande de mokroflora aanwezig in normaal en serehziek suikerriet. (Investigations of the microflora present in normal and sereh-diseased sugar cane.) Meded. Proefstat. Java Suikerind. 9:321-481, 1923. (Rev. Appl. Mycol. 3(5) : 302-303, 1924.)

An extensive study on the possibility of this disease being due to bacteria.

\section{Wood, E. J. F.}

Bureau of Sugar Experiment Station. Asst. Pathologist Report. Queensland Agric. Journ. 27(5) : 395-396, 1927. (Rev. Appl. Mycol. 6: 696-697, 1927.)

Brief reference to mosaic of sugar cane.

Bureau of Sugar Experiment Stations. Asst. Pathologist Report. Queensland Agric. Journ. 27(4) :273-275, (5) : 395396, 1927.

A brief report on mosaic of sugar cane. 
Cane diseases. Queensland Agric. Journ. 27(6) : 498-499, 1927. (Rev. Appl. Ent. Ser. A. $15: 661,1927$.

A brief report on mosaic of sugar cane.

Mosaic in Southern Queensland. Australia Sugar Journ. 18: 746-747, 1927.

Fiji disease in the Maryborough district. Queensland Agric. Journ. 27(5) : 388-393, 1927.

A report on cause, transmission, rate of spread, losses, effects and regulation for control.

\section{Woods, Albert F[red]}

The Bermuda lily disease. A preliminary report of investigations. U.S.D.A., Div. Veg. Phy. \& Path. Bul, 14, 15 p., 1897. A discussion of the author's studies on this disease which he believes to be due to aphids.

"The destruction of chlorophyll by oxidizing enzymes." Centralb. Back Zweite Abt., 5: 745-754, 1899.

A preliminary paper on the above title in which the author discusses the mosaic of tobacco and advances the oxidizing enzyme theory.

Inhibiting action of oxidase upon disease. Science. n. s. 11 (262) : 17-18, 1900.

A brief statement of the oxidizing enzyme theory.

Observations on the mosaic disease of tobacco. U. S. Bur. Plant. Industry Bull. 18, 24 p., 1902.

A historical review of the work to that time followed by a.discussion of his work in which he expressed the opinion that the disease is caused by oxidizing enzymes.

\section{Woods, Mark W.}

Intracellular bodies in ringspot. Phytopathology (Abstract) 23(1) : 38, 1933. (Contr. Boyce Thompson Inst. 5(3):419. $434,1933$.

The author reports the finding of intracellular bodies, resembling those of tobaceo mosaic in primary and systemic ringspot lesions in Turkish tobaceo, in primary lesions in Havana Seed-leaf, Nicotiana rustica, N. glutinosa and Petunia.

Cellular changes in ring-spot. Contrib. Boyce Thomp. Inst. 6 (1) : 51-67, 1934. 
The author introduces this paper with a very brief review of other investigators' work. He gives the results of his studies on cytology and the influence of environmental conditions.

\section{Woodworth, H[arold] $\mathbf{E}$ [vans]}

Sugar-cane pests at San José, Mindoro. Sugar Center \& Plant. News. 3:116-117, 1922.

\section{Wortley, $\mathbf{E}$ [dward] J[ocelyn]}

The transmission of potato through the tuber. Science. N. S. $42(1083)$ : 460-461, 1915.

A brief paper giving positive experimental results.

Potato leaf-roll: its diagnosis and cause. Phytopathology 8 (10) : 507-529, 1918.

The disease may cause heavy losses ranging from 50 to 100 per cent. The author gives descriptions of the disease under different environmental conditions.

Wright, W. P.

Potato leaf-curl. Journ. Board. Agr. 14:466-470, 1907.

Wuthrich, E.

Yellow stripe disease in Natal. South Africa Sugar Journ. Annual, 1920-21, p. 157, 1921.

The sugar industry in Natal and Zululand. Int. Sugar Journal. 24 : 243-247, 1922.

Yellow stripe disease in Natal. South African Sugar Journ. $9: 181,183,1925$.

\section{Yeh Yuen Ting}

(A disorder of cotton plant in China. Clubleaf or cyrtosis.) Chang-Lien-Ho-Hui-Ki-Kan (China Cotton Journal) 2:235240, 1921.

A translation of O. F. Cook paper on "A disorder of cotton plants in China" Clubleaf or eyrtosis. 1920.

Yoder, $\mathbf{P}$ [eter] A.

Pests and diseases of sugar cane. The mosaic disease, its appearance and control. Facts About Sugar 15(23) : 462-463, 1922.

Rare cases of mosaic disease in highly resistant varieties of sugar cane. U.S.D.A. Circ. 392, 7 p., 1926. (The Planter \& 
Sugar Manufac. 77(1):6-8, 1926. The Inter. Sugar Journ. 28(332) : 411-415, 1926. (El Mundo Azucarero (Spanish) 14 (1) : 20-23, 1926.)

This paper gives a record of the finding of mosaic in varieties sup. posed to be immune.

\section{Young, Arthur}

On the curl in potatoes. Young's Ann. Agric. 1:133, 1784. This paper is of historical interest.

A fortnight's tour in Kent and Essex, etc. Young's Ann. 2: 98-115, 1807.

This paper is of historical interest.

\section{Young, P[aul] A[llen], \& IMorris, H[arry] E[lwood]}

Potato witches' broom is a transmissible disease. U.S.D.A. Preliminary Report) Plant Disease Reporter 10(3):26-28, 1926.

The first report of the transmission of this disease.

Transmission of potato witches' broom to tomato and potatoes. . Science n. s. 66(1709) : 304-306, 1927.

A preliminary paper in which the author reports the transmission of the disease from potatoes to tomatoes and to several varieties of potatoes.

\section{\& INorris, H[arry] $\mathbf{E}[$ lwood]}

Witches' broom of potatoes and tomatoes. Journ. Agric. Res. 36(10) : 835-854, 1928.

This paper is devoted to a discussion of symptoms, methods of transmission and a brief discussion of the histology.

Tobaceo witches' broom. (A preliminary Report.) Amer. Journ. Bot. 16(5) : 277-279, 1929.

This is a preliminary paper in which the author discusses transmission and histology.

Research on potato viruses in Montana. Phytopathology (Abstract) $20(1): 125,1930$.

\section{\& Morris, H[arry] E[lwood]}

Researches on potato virus diseases in Montana. Montana Agric. Expt. Sta. Bull. 231, 51 p., 1930.

An extensive account of different types of virus diseases and the behavior of varieties. Insect vectors are observed. A bibliography of 100 titles is appended. 
Zaprometoff, N. G.

(Bacteriosis and dwarfiness.-New diseases of mulberry in Central Asia.) Moskow 5:36-38, 1932. (Rev. Appl. Mycol. $11: 756,1932$.)

\section{Zaumeyer, W[illiam] J.}

Transmission of bean-mosaic virus by insects. Phytopathology (Abstract) 23(1):40, 1933.

Transmissibility by certain legume mosaic viruses to bean. Phytopathology (Abstract) 23(1):39, 1933.

\section{\& Wade, B. L.}

Mosaic diseases affecting different legumes in relation to beans and peas. Phytopathology 23(6) :562-564, 1933.

An attempted brief classification of the viruses causing the mosaic diseases of beans and peas.

\section{Zedtwitz, W[ilhelm] von}

(The leaf roll disease and the bacterial ring disease of the potato.) Wiener Landw. Ztg. 59(83) : 818-819, 1909. (Abstr. Centrbl. Bkt. 2. Abt. 26(4-5):117-118, 1909.)

\section{Zeller, Sanford IM[yron]}

Mosaic and other systematic diseases of brambles in Oregon. Oregon Agric. Expt. Sta. Circ. 49, 15 p., 1923.

History and symptoms with list of susceptible varieties.

Mosaic disease of the loganberry. Phytopathology (Abstract) $14(2): 119,1924$.

Some facts about the loganberry "dwarf". Phytopathology (Abstract) 15(2): 125, 1925.

Preliminary reports on transmission of dwarf of loganberry. Phytopathology (Abstract) 15(11) : 732, 1925.

Preliminary studies on witches' broom of strawberry. Phytopathology 17(5) : 329-335, 1927.

The author gives a description of the disease and a statement that 1 t can be carried by Myzus fragaefollii.

Dwarf of blackberries. Phytopathology 17(9):629-648, 1927. This is a very complete discussion of this disease. 
A witches' broom of ocean spray (Holodiscus discolor Max.) Phytopathology 20(10): 851, 1930.

Notes on a witches' broom of Holodisous discolor Max which is probably a virus disease.

A witches broom of ocean spray, Holodiscus discolor. Phytopathology 21(9) : 923-925, 1931.

Description of a disease which causes broominess and dwarfing of Holodiscus discolor in Washington and Oregon States. Transmission was successful by means of grafting and Aphid spiraceae. The symptoms and performance of the disorder suggest that it may be a virus disease.

\section{\& Vaughan, E. $\mathbf{K}$.}

Crinkle disease of strawberry. Phytopathology 22(8):709713, 1932.

This disease appears to be limited to the Pacific coast. It appears to be a virus disease but there is no absolute proof.

Crinkle disease of strawberry. Oregon Agric. Expt. Sta. Bull. 319, 14 p., 1933.

Popular account of this disease of widespread occurrence in the Pacific coast region of the United States. Gives the behaviour of the disease on different varieties and also comparisons with other types of diseases of this group.

\section{Zeylstra, H. H.}

Versuch einer Erklärung der "Sereh" Erscheinungen des Zuckerrobres. Ber. Deut. Bot. Ges. 29(6) : 330-333, 1911.

\section{Ziegler, 0.}

Kritische Betrachungen zur Oekelogie des Abbaues. In Mer.kensachlager, F. Zur Biologie der Kartoffel. Arb. Biol. Reichsanst. Land-u. Forstw. Berlin-Dahlem. 19(2) : 135-154, 1935. Review of the literature relating to the ecology of potato degeneration, followed by much interesting data.

\section{Zimmermann, A[lbrecht Wilhelm Philipp]}

Die Kräuselkrankheit des Manioks. (The leaf curl of cassava.) Der Tropenpflanzer 2(10) : 145-153, 1906.

Einige Bemerkungen über Maniok, Kassave (Some observations on Manioc or Cassava.) Der Tropenpflanzer 2: 257-270, 1906.

(A disease of peanuts.) Tropenpflanzer 3(9) : 129-133, 1907. 
Die Kräuselkrankheit des Manioks (Mhogo) und die abgabe gesunder Stecklinge. Der Tropenpflanzer 5:184-185, 1909.

Der Manihot-Kautschuk seine Kultur Gewinnung und Präparation. Die Kräuselkrankheit p. 126-127, Jena, 1913.

Die "bunchy top disease" der Bananen auf Ceylon. (The "Bunchy top disease" of bananas in Ceylon.) Tropenpflanzer 34: 82-83, 1931.

Note, reviewing the work done in regard to this virus disease.

\section{Zundel, George L[orenzo Ingram]}

Mosaic and related diseases of the potato. Washington State College Expt. Sta. Ser. Bull. 105, 8 p., 1923.

Why raspberry "Run Out". West Fruit 7: 7, 1925.

The author attributes "running out" to virus diseases.

What the virus diseases mean to the potato growers of Washington. North-west. Sci. (Abstract) 1(3) : 53-54, 1927.

New or unusual symptoms of virus diseases of raspberries. Phytopathology 21(7) : 755-757, 1931.

Brief notes on the unusual types "fern leaf" and "witches broom", of raspberry diseases are given.

$$
0-0-0
$$

